\author{
UNIVERSIDADE DE SÃO PAULO \\ ESCOLA DE ENFERMAGEM \\ PROGRAMA DE PÓS-GRADUAÇÃO EM ENFERMAGEM
}

FERNANDA JACQUELINE TEIXEIRA CARDOSO

ESCORPIONISMO NA AMAZÔNIA:

A EPIDEMIOLOGIA, A CLÍNICA E A VULNERABILIDADE AOS

ACIDENTES ESCORPIÔNICOS EM RURÓPOLIS, PARÁ, BRASIL

SÃO PAULO

2019 
ESCORPIONISMO NA AMAZÔNIA:

\title{
A EPIDEMIOLOGIA, A CLÍNICA E A VULNERABILIDADE AOS ACIDENTES ESCORPIÔNICOS EM RURÓPOLIS, PARÁ, BRASIL
}

\author{
Versão corrigida da Tese de Doutorado \\ apresentada ao Programa de Pós-graduação em \\ Enfermagem (PPGE) da Escola de \\ Enfermagem da Universidade de São Paulo \\ (EEUSP) como requisito para obtenção do \\ título de Doutora em Ciências. \\ Área de Concentração: Enfermagem em Saúde \\ Coletiva
}

Orientadora: Prof. Dra. Lucia Yasuko Izumi Nichiata

Co-orientador Dr Francisco Oscar França;

\section{VERSÃO CORRIGIDA}

A versão original encontra-se disponível na Biblioteca da Escola de Enfermagem da Universidade de São Paulo e na Biblioteca e na Biblioteca Digital de Teses e Dissertações da Universidade de São Paulo.

\section{SÃO PAULO}


AUTORIZO A REPRODUÇÃO E DIVULGAÇÃO TOTAL OU PARCIAL DESTE TRABALHO, POR QUALQUER MEIO CONVENCIONAL OU ELETRÔNICO, PARA FINS DE ESTUDO E PESQUISA, DESDE QUE CITADA A FONTE.

Assinatura:

Data:

Catalogação na Publicação (CIP)

Biblioteca "Wanda de Aguiar Horta"

Escola de Enfermagem da Universidade de São Paulo

Cardoso, Fernanda Jacqueline Teixeira

Escorpionismo na Amazônia: a epidemiologia, a clínica e a vulnerabilidade aos acidentes em Rurópolis, Pará, Brasil / Fernanda Jacqueline Teixeira Cardoso. São Paulo, 2019.

$180 \mathrm{p}$.

Tese (Doutorado) - Escola de Enfermagem da Universidade de São Paulo.

Orientadora: Prof.a Dr.a Lucia Yasuko Izumi Nichiata

Coorientador: Dr. Francisco Oscar França

Área de concentração: Enfermagem em Saúde Coletiva

1. Escorpiões. 2. Envenenamento. 3. Saúde pública. 4. Vulnerabilidade. 5. Enfermagem. I. Título.

Ficha catalográfica elaborada por Fabiana Gulin Longhi Palacio (CRB-8: 7257 
Nome: Fernanda Jacqueline Teixeira Cardoso

Título: Escorpionismo na amazônia: a epidemiologia, a clínica e a vulnerabilidade aos acidentes em Rurópolis, Pará, Brasil.

Tese apresentada ao Programa de Pós-Graduação Em Enfermagem da Escola de Enfermagem da Universidade de São Paulo para obtenção do título de Doutora em Ciências.

Aprovado em:

Banca Examinadora

Orientador: Prof. Dra. Lúcia Yasuko Izumi Nichiata

Instituição: EEUSP Assinatura:

Co - Orientador: Prof. Dr Francisco Oscar de Siqueira França

Instituição: FMUSP Assinatura:

Prof. Dr. Rogério Bertani

Instituição: Butantã

Julgamento:

Assinatura:

Prof. Dra. Maria Rita Bertolozzi

Instituição: EEUSP

Julgamento:

Assinatura:

Prof. Dra. Pasesa Pascuala Quizpe Torrez

Instituição: FMUSP

Julgamento:

Assinatura:

Prof. Dra. Sheyla Mara Silva de Oliveira

Instituição: UEPA

Julgamento:

Assinatura:

Prof. Dra Palmira Cupo

Instituição: FMUSP

Julgamento:

Assinatura:

Prof. Dra. Anna Luiza de Fátima Pinho Lins Gryschek Instituição: EEUSP Julgamento: Assinatura: 


\section{DEDICATÓRIA}

Aos meus filhos Maria Teresa, Gabriel, Carolina, Derick, Adele e Pedro Henrique, fontes de amor, energia e cuidado. Por eles e para eles que vivo.

Aos meus amorosos pais, Felipe e Teresa, por todo investimento, incentivo, lições, todo carinho e esforço para que eu chegasse até aqui.

Ao meu amor, Vando, que andou ao meu lado e, muitas vezes me conduziu, em cada passo dessa caminhada.

À minha irmã, Fabiana (in memoriam) e minha avó Ana (in memoriam), amores e anjos meus que iluminam e me protegem.

À minha família, irmãos, cunhadas, cunhados, sogros, sobrinhos, primos, comadres, amigos verdadeiros, enfim, a todos que me ajudaram e compartilharam comigo momentos felizes e difíceis.

A todos que participaram dessa pesquisa, seja como participante ou pesquisadora, sem vocês nada seria possível. 


\section{EPÍGRAFE}

Lamento da Raça

O índio chorou, o branco chorou Todo mundo está chorando A Amazônia está queimando

$\mathrm{Ai}$, ai, que dor $\mathrm{Ai}$, ai, que horror O meu pé de sapopema Minha infância virou lenha $\mathrm{Ai}$, ai, que dor $\mathrm{Ai}$, ai, que horror

Lá se vai a saracura correndo dessa quentura

E não vai mais voltar Lá se vai onça pintada fugindo dessa queimada E não vai mais voltar Lá se vai a macacada junto com a passarada

Para nunca mais, voltar Para nunca mais, nunca mais voltar Virou deserto o meu torrão Meu rio secou, pra onde vou? Eu vou convidar a minha tribo

Pra brincar no Garantido

Para o mundo declarar Nada de queimada ou derrubada A vida agora é respeitada todo mundo vai cantar

Vamos brincar de boi, tá Garantido

Matar a mata, não é permitido 


\section{AGRADECIMENTOS}

Chegar até aqui não foi fácil e só consegui porque, graças a Deus, muitas pessoas me ajudaram. Então eu agradeço...

A Deus pelo dom da vida, por ter colocado pessoas maravilhosas em meu caminho, por cuidar tão bem de mim, por encher minha vida de alegria e amor.

Ao meu companheiro, Vando, pelos quase 25 anos, meu primeiro e único amor, que me acompanha por todos os caminhos, que me protege, acalma e me faz rir mesmo em momentos tensos. A ti, todo meu amor, meu agradecimento por me ajudar não somente em casa com as crianças, mas nas tabulações de dados também e os meus devaneios. Só cheguei a vitória porque você me trouxe até aqui. Muito obrigada!

Aos meus filhos queridos e tão amados, que sofreram com minha ausência nos momentos em que precisei me dedicar ao estudo e ao trabalho. Maria, Biel, Dérick, Carol, Adele e Pedroca, a vocês dedico e dedicarei todos os dias de minha vida e todo meu amor. Esta caminhada não teria sentido se não fosse por vocês.

Aos meus pais, Felipe e Teresa, que tiveram pouco acesso ao ensino de qualidade, mas souberam conduzir seus filhos para serem homens e mulheres honradas e dignos. Ao meu pai que se gradou após os 60 anos, minha fonte de inspiração para trilhar na busca por uma educação melhor. À minha mãe que é meu socorro para toda e qualquer situação, que me dá colo e é fonte de amor incondicional. Vocês são meu orgulho!

Aos meus avós Raimundo (in memoriam), Ana (in memoriam) e Julia (in memoriam), caboclos ribeirinhos, descendentes de indígenas, que trouxeram meus pais para a cidade para poderem estudar. De vocês guardo as mais doces lembranças.

Aos meus irmãos Flávia, Fábia, Fabiana (in memoriam), Felipe Junior, Flávio, Fabrícia, João Paulo, Fábio e Janice, por serem meus companheiros de jornada nessa vida, por me ajudarem em tudo e pelo amor fraterno que nos une.

Aos meus sogros, Laurindo e Lourdes. Tia Lourdes, mulher trabalhadora, mãe e avó amorosa, presente de Deus em minha vida, Muito Obrigada por tudo!

Aos meus sobrinhos Felipe Neto, Marco Aurélio, Clara, Luiza, Michele, Erick, Lucas, Luan, Charles, Tayonara, Odália, Paulo, Augusto, Luiz, Otávio, Wallacy, Enzo e, especialmente, à Ana Beatriz e Ana Mônica que me ajudaram na tabulação dos dados e na tradução dos artigos, respectivamente. Aos meus sobrinhos netos Dudinha, João Pedro, Isabela, Alexandre e Lara. A vocês, meus amores, a tia agradece por todo carinho e amor.

Aos meus cunhados, Mansuete, Arthur, Luciano, Laurison, Isis, Nayara e, especialmente, a Arlete e Thaíse que são mais que cunhadas, são amigas e irmãs que Deus me deu e que ajudam a cuidar das minhas crianças como se fossem suas. Eu só tenho a agradecer profundamente todo apoio, amizade e ajuda que me dão e que ainda me darão.

Às minhas amigas verdadeiras e comadres, Inara e Rafaela, pela amizade e amor fraternal e que, mesmo estando distantes, não se ausentam da vida dos meus filhos. 
À dona Iris que tem sido uma mãe e amiga, com quem sempre posso contar. À Eliciane, Anaila, Letícia, Lorena, Bira, Roberto e Gláucia, amigos de trabalho e de vida, que quero ter sempre por perto. A Cléia e Shayanne, minhas ex-alunas, amigas e competentes enfermeiras. Cléia, obrigada pelo mapa de distribuição dos acidentes e obrigada, Shay, pelo belo ensaio fotográfico dos escorpiões.

Às minhas amigas e pesquisadoras queridas, que foram incansáveis e essenciais, sem as quais eu não teria conseguido: Josivane, Yamilles e Ana Beatriz. Muito obrigada por tudo que fizeram e fazem por mim! Á enfermeira Néia e Técnica de Enfermagem Iraci Rocha pela valiosa contribuição ao acompanhar os pacientes do Peixotinho. À Taise que me ajudou no abstract.

Aos meus amigos de jornada em Santarém, Rurópolis e São Paulo, com os quais convivi e dividi momentos felizes, risadas, sonhos e angústias: Sheyla, Nádia, Livia, Tatiane, Vandinha, Mônica, Veridiana, Erli, Branca, Lorrayne, Larissa, Muciane, Marcílio, João e Fabiana. Vocês marcaram minha vida e minha história. Muito obrigada!

À Giovanna Orlandi pelo carinho e pela valiosíssima ajuda que tem me dado, principalmente com o abstract.

À Escola de Enfermagem Magalhães Barata da Universidade do Estado do Pará, minha casa desde a graduação.

À Escola de Enfermagem da Universidade de São Paulo que acolheu a mim, a Carol e a Vandinha nos meses de aula. Onde cresci e aprendi absurdamente, onde conheci pessoas maravilhosas e de coração enorme.

À minha querida orientadora, Lucia Izumi, pessoa maravilhosa! Obrigada, pelos ensinamentos, pelos conselhos e por todo carinho com que me acolheu, mesmo eu deixando a desejar em muitos momentos.

Aos meus queridos professores Rita Bertolozzi e Francisco França, casal iluminado e abençoado por Deus. Muito obrigada por todo carinho e conhecimento compartilhado!

À Dra Pasesa Torrez pelas valiosas contribuições à tese. Ao Dr Rogério Bertani pela identificação dos escorpiões e por todo conhecimento e contribuição ao estudo.

Agradeço à toda equipe da Secretaria e aos profissionais de saúde de Rurópolis, em especial, aos que atuam no Hospital Municipal.

Agradeço à cada participante dessa pesquisa, que mesmo estando em um momento de dor e desconforto, foram solícitos e respondiam às nossas solicitações.

A todos que me incentivaram, torceram e ajudaram para que esse sonho se tornasse realidade, o meu muito obrigada! 
Cardoso, FJT. Escorpionismo na amazônia: a epidemiologia, a clínica e a vulnerabilidade aos acidentes em Rurópolis, Pará, Brasil [Tese]. São Paulo: Escola de Enfermagem, Universidade de São Paulo; 2019.

\section{RESUMO}

Introdução: $O$ acidente escorpiônico é um grave problema de saúde no Brasil e, especificamente, no Oeste do Pará onde ocorre severo e agudo comprometimento neuromuscular, diferenciado dos demais acidentes no mundo. A ocorrência do escorpionismo na Amazônia carece de análise aprofundada sobre os contextos individuais e coletivos que estão envolvidos nos acidentes. Objetivo: Analisar os aspectos epidemiológicos e clínicos dos acidentes escorpiônicos ocorridos no município de Rurópolis, Pará, propondo uma matriz de marcadores de vulnerabilidade. Método: Estudo multimétodo com abordagens qualitativa e quantitativa, observacional, descritivo e prospectivo. Foi realizado acompanhamento em tempo real de 117 vítimas de escorpionismo atendidos no Hospital Municipal de Rurópolis, Pará, no período de outubro de 2016 a setembro de 2017. Os dados foram coletados a partir do questionário aplicado aos pacientes e acompanhantes, de registros dos prontuários e das fichas de notificação. A discussão dos dados foi feita à luz do conceito de vulnerabilidade tendo por referência teórica a Determinação Social do Processo Saúde e a Epidemiologia Crítica. Resultados: Homens, mulheres e crianças se acidentam em contextos e espaços diferentes. No entanto, os homens $(75,20 \%)$, negros $(84,62 \%)$, da faixa etária adulta $(50,45 \%)$, agricultores $(49,57 \%)$ são as principais vítimas. Os acidentes ocorreram nos meses de abril a junho $(41,87 \%)$, em área rural $(45,30 \%)$, no período matutino $(41,02 \%)$, durante o trabalho $(50,42 \%)$ e envolvendo escorpião preto $(88,07 \%)$. A escorpiofauna do estudo foi composta por $T$. obscurus e T. strandi. Por meio da evolução clinica pôde ser verificado que seus venenos ultrapassam a barreira hematoencefálica, chegam imediatamente ao sistema nervoso central e causam disfunção cerebelar aguda. Entre os acidentados, um sofreu picada seca e os demais manifestaram sintomas locais $(79,49 \%)$ e sistêmicos $(82,91 \%)$, sendo que dor, parestesia e sensação de choque elétrico pertenceram às duas categorias. As manifestações neuromusculares (ataxia, disartria, mioclonia, dismetria, tremores e astenia), oftalmológicas (visão turva e hipotonia palpebral) e cardiorrespitarórias (hipertensão arterial e taquipneia) foram mais exuberantes. Os sintomas diplopia, sensação de areia nos olhos, disgeusia, espasmo faríngeo e convulsão são descritos pela primeira vez em escorpionismo na Amazônia. Os marcadores de vulnerabilidade coletiva e individual se entrelaçam e transitam nas dimensões. A vulnerabilidade coletiva foi evidenciada pelo modo de produção e reprodução social dos grupos, pela constatação da tríplice inequidade, além de fragilidades no serviço público de saúde em todos níveis hierárquicos que restringem o acesso à uma assistência segura e de qualidade. A vulnerabilidade individual se expressa nas características pessoais que conferem proteção ou desgaste e nas condições clínicas que predispõem ao agravamento. Conclusão: Aspectos sociais, econômicas, ambientais e de acesso às políticas públicas compõem marcadores de vulnerabilidade dos indivíduos ao acidente por escorpião. A disfunção cerebelar aguda, manifestações oftalmológicas, cardiorrespiratórias, digestivas e urinárias ocorrem em envenenamentos por escorpiões pretos e amarelos. O antiveneno disponibilizado no Brasil não é eficaz para reduzir o tempo de duração dos principais sintomas neuromusculares, podendo causar quadros alérgicos. O T. strandi também é um escorpião de importância clínica na Amazônia.

PALAVRAS-CHAVE: Escorpião. Envenenamento. Saúde Coletiva. Vulnerabilidade.

Enfermagem. 
Cardoso FJT. Scorpionism in the Amazon: epidemiology, clinic, and vulnerability to accidents in Rurópolis, Pará, Brazil [thesis]. São Paulo: Escola de Enfermagem, Universidade de São Paulo; 2019.

\section{ABSTRACT}

Introduction: Scorpion accident is a serious health problem in Brazil and, specifically, in West of Pará, where many patients develop severe and acute neuromuscular involvement, unlike other scorpion accidents in the world. The occurrence of scorpionism in the Amazon requires an in-depth analysis of the individual and collective contexts that are involved in the accidents. Objective: To analyze the epidemiologic and clinical aspects of the scorpion accidents ocurred in the city of Rurópolis, Pará, in order to obtain a matrix of vulnerability markers. Method: A multi-method study with qualitative, quantitative, observational, descriptive and prospective approaches. It was performed a real-time follow-up of 117 scorpion victims attended at the Municipal Hospital of Rurópolis, Pará, from October 2016 to September 2017. Data were collected through a questionnaire applied to patients and their companions, in addition to medical record and notification forms information. The discussion of the data was made according to the vulnerability conception, having as a theoretical framework the Social Determination of Health and the Critical Epidemiology. Results: The main victims were men (75.20\%), black $(84.62 \%)$, in adult age $(50.45 \%)$, farmers $(49.57 \%)$, and with incomplete elementary education (68.37\%). The accidents happened from April to June (41.87\%), in rural areas $(45.30 \%)$, in the morning $(41.02 \%)$, during work $(50.42 \%)$, and involving black scorpion (88.07\%). The scorpion species of the study were T. obscurus and T. strandi. During the clinical evolution, it was verified that the scorpion venom crossed the blood-brain barrier, reaching the central nervous system immediately and causing acute cerebellar dysfunction. One patient suffered a dry sting and the others manifested local symptoms $(79.49 \%)$ and systemic symptoms $(82.91 \%)$. Both manifestations had pain, paresthesia, and electric shock sensation. The neuromuscular (ataxia, dysarthria, myoclonus, dysmetria, tremors, and asthenia), the ophthalmic (blurred vision and eyelid hypotonia) and cardiorespiratory (hypertension and tachypnea) manifestations were more expressive. Diplopia, foreign body sensation in the eyes, dysgeusia, pharyngeal spasm and convulsion are described at the first time in scorpionism in the Amazon. The markers of collective and individual vulnerability intertwine and transit in the dimensions. The collective vulnerability was highlighted by the production and social reproduction of the groups, the verification of the triple inequality, as well as weaknesses in the public health service at all hierarchical levels that limit the access to safe health and quality care. Individual vulnerability is expressed in the personal characteristics that give protection or weaknesses and clinical conditions that predispose to aggravation. Conclusion: Social, economic and environmental aspects and the access to the public policy are markers of vulnerability of individuals to scorpion accident. Acute cerebellar dysfunction along with ophthalmologic, digestive, and urinary manifestations, not yet described in Amazonian scorpionism, can happen in black and yellow scorpion envenomation. The antivenomous available in Brazil are not able to reduce the duration of major neuromuscular symptoms. $T$. strandi is also a scorpion of clinical importance in the Amazon.

Keywords: Scorpion. Poisoning. Collective Health. Vulnerability. Nursing. 


\section{LISTA DE FIGURAS}

Figura $01 \quad$ Morfologia do escorpião

Figura 02 Exemplares adultos de Tityus obscurus que causaram acidentes em Rurópolis, Pará. a) Escorpião macho; b) Escorpião Fêmea

Figura 03 Classificação dos acidentes escorpiônicos quanto à gravidade, 37 manifestações clínicas e tratamento específico.

Figura 04

Classificação da gravidade do acidente escorpiônico, segundo

o Manual de Rotinas - Acidentes por Animais Peçonhentos.

Figura 05

Figura 06

Figura 07

Figura 08

Figura 09

Figura 10

Figura 11

Figura 12

Figura 13

Figura 14

Figura 15
Município de Rurópolis - Pará e b) Rodovias Transamazônica (BR 230) e Santarém- Cuiabá (BR 163).

Tityus Obscurus jovem causador de acidente $\mathrm{n}^{\circ} 03$, no Travessão da Perdida, BR 230e BR 163, zona rural, Rurópolis, 2016. Legenda: a) face ventral; b) face dorsal.

Tityus strandi causador de acidente $\mathrm{n}^{\circ} 36$, na Comunidade Peixotinho, Km 75, BR 230 e BR 163, zona rural, Rurópolis, 2017.

Tityus obscurus macho causador de acidente $\mathrm{n}^{\circ} 84$, no Travessão dos Baianos, zona rural, Rurópolis, 2017.

Tityus obscurus fêmea causadora de acidente ${ }^{\circ} 96$, na Vicinal da Eletronorte, Zona rural, Rurópolis,2017.

Tityus obscurus causador do acidente $\mathrm{n}^{\circ} 113$, BR 230, Bairro Centro, Zona Urbana, Rurópolis, 2017.

Tityus obscurus fêmea causadora do acidente $\mathrm{n}^{\circ} 13$, carregando filhotes em seu dorso, Travessão das Águas Frias, BR 163, Zona rural, Rurópolis, 2016.

Distribuição espacial das vítimas de acidentes escorpiônicos no espaço rural do município de Rurópolis, Pará, no período de outubro de 2016 a setembro de 2017.

Distribuição espacial das vítimas de acidentes escorpiônicos no espaço urbano e periurbano do município de Rurópolis, Pará, no período de outubro de 2016 a setembro de 2017.

Pacientes apresentando pupilas anisocóricas. Legenda: a) Paciente caso 10, b) Olho direito (caso 2 ); c) Olho Esquerdo (caso 3).

Criança vitima de Escorpionismo apresentando urticária após a administração do antiveneno, 2016. 86 98 


\section{LISTA DE QUADROS}

Quadro 01 Classificação de gravidade clínica das vítimas de escorpionismo, 2011.

Quadro 02 Variáveis contidas na ficha protocolar aplicada às vítimas de acidentes escorpiônico em Rurópolis, Pará.

Quadro 03 Aspectos sociais, epidemiológicos, clínicos e terapêuticos das vítimas de acidente escorpiônico, que apresentaram o animal para identificação, atendidos no Hospital Municipal de Rurópolis, Pará, outubro 2016 a setembro de 2017.

Quadro 04 Marcadores de vulnerabilidade individual identificados nos dados obtidos das vítimas de acidentes escorpiônico em Rurópolis, Pará.

Quadro 05 Marcadores de vulnerabilidade programática identificados nos dados obtidos das vítimas de acidente escorpiônico em Rurópolis, Pará.

Quadro 06 Marcadores de vulnerabilidade social identificados nos dados obtidos das vítimas de acidente escorpiônico em Rurópolis, Pará.

Quadro 07 Categorias analíticas das dimensões da vulnerabilidade das vítimas de acidente escorpiônico em Rurópolis, Pará. 


\section{LISTA DE GRÁFICOS}

Gráfico 01 Distribuição dos acidentes escorpiônicos, por mês de ocorrência,

durante os meses de outubro de 2016 a setembro de 2017 , Rurópolis, Pará.

Gráfico 02 Distribuição das vítimas de acidentes escorpiônicos em Rurópolis, segundo o local de ocorrência e sexo, outubro 2016 a setembro 2017.

Gráfico 03 Distribuição das vítimas de acidentes escorpiônicos em Rurópolis, segundo o contexto e sexo, outubro 2016 a setembro de 2017.

Gráfico 04 Distribuição das crianças e jovens vítimas de acidentes escorpiônicos em Rurópolis, segundo o local de ocorrência e contexto, outubro de 2016 a setembro de 2017.

Gráfico 05 Distribuição das vítimas de acidentes escorpiônicos em Rurópolis, manifestações clínicas, outubro de 2016 a setembro de 2017.

Gráfico 06 Distribuição das vítimas de acidentes escorpiônicos em Rurópolis, segundo manifestações clínicas locais, outubro de 2016 a setembro de 2017.

Gráfico 07 Distribuição das vítimas de acidentes escorpiônicos no município de Rurópolis- PA, segundo tempo para início dos sintomas dor, parestesia e sensação de choque elétrico, outubro 2016 a setembro de 2017.

Gráfico 08 Distribuição das vítimas de acidentes escorpiônicos no município de Rurópolis- PA, segundo tempo de duração dos sintomas dor, parestesia e sensação de choque elétrico, outubro 2016 a setembro de 2017.

Gráfico 09 Distribuição das vítimas de acidentes escorpiônicos no município de Rurópolis- PA, segundo localização dos sintomas dor, parestesia e sensação de choque elétrico, outubro 2016 a setembro de 2017.

Gráfico 10 Distribuição das vítimas de acidentes escorpiônicos no município de Rurópolis- PA, segundo intensidade da dor, outubro 2016 a setembro de 2017.

Gráfico 11 Distribuição das vítimas de acidentes escorpiônicos no município de Rurópolis- PA, segundo tempo para início dos sintomas disartria, mioclonia, ataxia e dismetria, outubro 2016 a setembro de 2017.

Gráfico 12 Distribuição das vítimas de acidentes escorpiônicos no município de Rurópolis- PA, segundo tempo de duração dos sintomas disartria, mioclonia, ataxia e dismetria, outubro 2016 a setembro de 2017. 
Gráfico 13 Distribuição das vítimas de acidentes escorpiônicos no município de Rurópolis- PA, segundo níveis pressóricos, outubro 2016 a setembro de 2017. 


\section{LISTA DE TABELA}

Tabela 01 Perfil sócio econômico das vítimas de acidentes escorpiônicos, município de Rurópolis, PA, outubro 2016 a setembro de 2017

Tabela 02 Perfil de saúde das vítimas de acidentes escorpiônicos no município de Rurópolis- PA, outubro de 2016 a setembro de 2017.

Tabela 03 Distribuição das vítimas dos acidentes escorpiônicos, segundo as condições de ocorrência, no município de Rurópolis- PA, outubro de 2016 a setembro de 2017.

Tabela 04 Distribuição das vítimas de acidentes escorpiônicos no município de Rurópolis - PA, segundo tempo para início, duração e localização dos sintomas Dor, Parestesia e Sensação de Choque Elétrico, outubro de 2016 a setembro de 2017

Tabela 05 Distribuição das vítimas de acidentes escorpiônicos no município de Rurópolis -PA, segundo tempo para início e duração dos sintomas disartria, mioclonia, ataxia e dismetria, outubro de 2016 a setembro de 2017.

Tabela 06 Distribuição das vítimas de acidentes escorpiônicos no município de Rurópolis- PA, segundo manifestações clínicas neuromusculares e cardiorrespiratórias, outubro de 2016 a setembro de 2017.

Tabela 07 Distribuição dos pacientes hipertensos vítimas de acidentes escorpiônicos no município de Rurópolis - PA, segundo gravidade e níveis pressóricos, outubro de 2016 a setembro de 2017.

Tabela 08 Distribuição das vítimas de acidentes escorpiônicos no município de Rurópolis- PA, segundo manifestações clínicas oftalmológicas, gastrointestinais, de pele e anexos e urinarias, outubro de 2016 a setembro de 2017.

Tabela 09 Distribuição dos pacientes picados por escorpião amarelo no município de Rurópolis- PA, segundo manifestações clínicas, outubro d 2016 a setembro de 2017.

Tabela 10 Distribuição das vítimas de acidentes escorpiônicos no município de Rurópolis- PA, segundo tempo para o atendimento e classificação clínica, outubro de 2016 a setembro de 2017.

Tabela 11 Relação de índice de massa corpórea e classificação clinica dos 
Tabela 12 Distribuição das vítimas de acidentes escorpiônicos no munícipio de Rurópolis- PA, segundo exames laboratoriais, outubro de 2016 a julho de 2017.

Tabela 13 Distribuição das vítimas de acidentes escorpiônicos no município de Rurópolis- PA, segundo eletrocardiograma, outubro de 2016 a julho de 2017.

Tabela 14 Distribuição das vítimas de acidentes escorpiônicos no município de Rurópolis-PA, segundo terapêutica, outubro de 2016 a julho de 2017.

Tabela 15 Distribuição das vítimas de acidentes escorpiônicos no município de Rurópolis- PA, segundo gravidade, dose de antiveneno administrada e duração dos principais sintomas neurológicos, outubro 2016 a setembro de 2017.

Tabela 16 Distribuição das vítimas de acidentes escorpiônicos do 99 município de Rurópolis- PA, segundo uso ou não de antiveneno e a duração dos sintomas neurológicos, outubro 2016 a julho de 2017. 


\section{LISTA DE SIGLAS}

\begin{tabular}{|c|c|}
\hline$\mu / \mathrm{L}$ & Micro por Litro \\
\hline ACE & Agente de Combate às Endemias \\
\hline $\mathrm{ACP}$ & Ausculta Cardiopulmonar \\
\hline ACS & Agente Comunitário de Saúde \\
\hline APS & Atenção Primária à Saúde \\
\hline ATM & Altamira \\
\hline BAV & Bloqueio Atrioventricular \\
\hline BR & Rodovia Federal Brasileira \\
\hline CEP & Comitê de Ética em Pesquisas \\
\hline CHCM & Concentração da Hemoglobina Corpuscular Média \\
\hline CIT & Comissão Intergestores Tripartite \\
\hline CNS & Conselho Nacional de Saúde \\
\hline CONASEMS & Conselho Nacional das Secretarias Municipais de Saúde \\
\hline CPK & Creatinoquinase \\
\hline CPK MB & Fração Mioglobina da Creatinoquinase \\
\hline DPVAT & $\begin{array}{l}\text { Danos Pessoais causados por Veículos Automotores de Vias } \\
\text { Terrestres }\end{array}$ \\
\hline EAS & Exame de Análise de Sedimentos \\
\hline ECG & Eletrocardiograma \\
\hline EPI & Equipamento de Proteção Individual \\
\hline ESF & Estratégia de Saúde da Família \\
\hline $\mathrm{EV}$ & Endovenoso \\
\hline EVA & Escala Visual Analógica \\
\hline $\mathrm{FC}$ & Frequência Cardíaca \\
\hline $\mathrm{Fl}$ & Femtolitro \\
\hline FLONA & Floresta Nacional do Tapajós \\
\hline FR & Frequência Respiratória \\
\hline g/dl & Grama por Decilitro \\
\hline $\mathrm{HCM}$ & Hemoglobina Globular Média \\
\hline HIV/AIDS & $\begin{array}{l}\text { Vírus da Imunodeficiência Humana/ Síndrome da } \\
\text { Imunodeficiência Adquirida }\end{array}$ \\
\hline HMR & Hospital Municipal de Rurópolis \\
\hline HTLV & Vírus Linfotrópico de Células T Humanas \\
\hline IBGE & Instituto Brasileiro de Geografia e Estatística \\
\hline $\mathrm{IC}$ & Intervalo de Confiança \\
\hline IDH & Índice de Desenvolvimento Humano \\
\hline $\mathrm{IM}$ & Intramuscular \\
\hline IMC & Índice de Massa Corpórea \\
\hline ITB & Itaituba \\
\hline $\mathrm{Km}$ & Quilômetros \\
\hline $\mathrm{mg} / \mathrm{dl}$ & Miligrama por decilitro \\
\hline $\mathrm{mm}^{3}$ & Milímetros cúbicos \\
\hline $\mathrm{mmHg}$ & Milímetros de Mercúrio \\
\hline NDBP & Peptídeos que Não Contem Ligações Dissulfeto \\
\hline $\mathrm{p} / \mathrm{c}$ & Piócitos por Campo \\
\hline PA & Pressão Arterial \\
\hline PACS & Programa de Agente Comunitário de Saúde \\
\hline PCR & Proteína C Reativa \\
\hline
\end{tabular}




$\begin{array}{ll}\text { PEC } & \text { Prontuário Eletrônico do Cidadão } \\ \text { Pg } & \text { Picograma } \\ \text { pH } & \text { Potencial Hidrogeniônico } \\ \text { PIB } & \text { Produto Interno Bruto } \\ \text { PMM } & \text { Programa Mais Médico } \\ \text { PQAVS } & \text { Programa de Qualificação de Ações de Vigilância em Saúde } \\ \text { PR } & \text { Intervalo entre a onda P e onda R (despolarização atrial) } \\ \text { QRS } & \text { Intervalo entre a onda Q e onda S (despolarização ventricular) } \\ \text { RDW } & \text { Red Cell Distribution Width } \\ \text { SAAR } & \text { Soro Anti Aracnídico } \\ \text { SAESC } & \text { Antiveneno } \\ \text { SIC } & \text { Segundo Informações Colhidas } \\ \text { SIH } & \text { Sistema de Informação de Informações Hospitalares } \\ \text { SINAN } & \text { Sistema de Informações de Agravos de Notificação } \\ \text { STM } & \text { Santarém } \\ \text { SUS } & \text { Sistema Único de Saúde } \\ \text { T } & \text { Temperatura } \\ \text { TA } & \text { Termo de Assentimento } \\ \text { Tc } & \text { Toxina de Tityus cambrigde } \\ \text { TCLE } & \text { Termo de Consentimento Livre e Esclarecido } \\ \text { TCUD } & \text { Termo de Consentimento de Uso de Dados } \\ \text { TGO } & \text { Transaminase Oxalacética } \\ \text { TGP } & \text { Transaminase Pirúvica } \\ \text { To } & \text { Toxina de Tityus obscurus } \\ \text { U/L } & \text { Unidades por Litro } \\ \text { UFPA } & \text { Universidade Federal do Pará } \\ \text { UHE } & \text { Usina Hidrelétrica } \\ \text { UTI } & \text { Unidade de Terapia Intensiva } \\ \text { VCM } & \text { Volume Corpuscular Média } \\ & \end{array}$




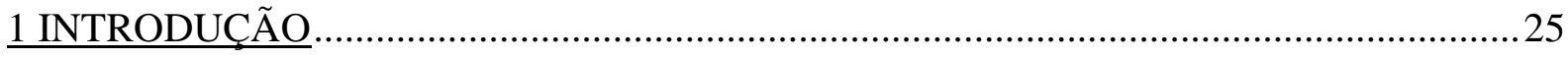

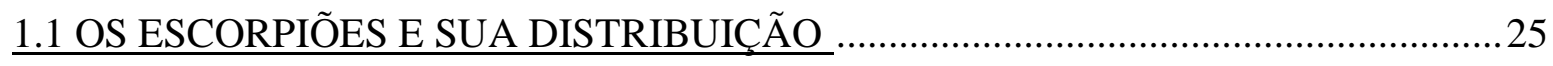

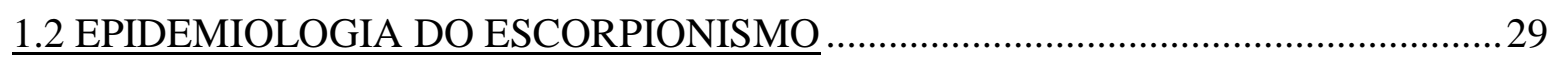

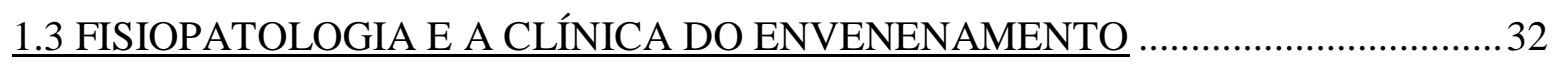

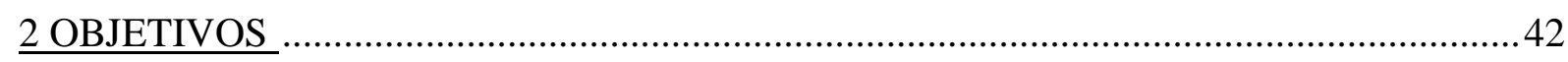

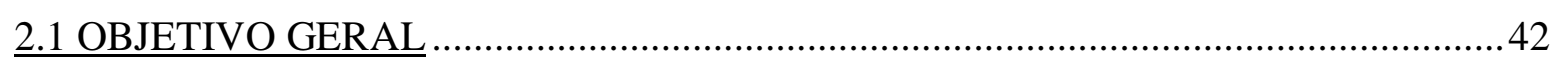

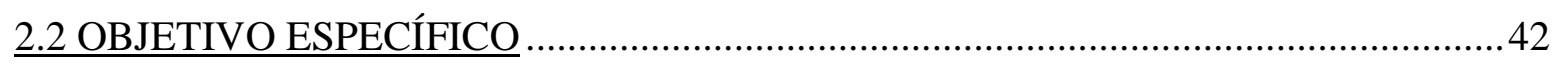

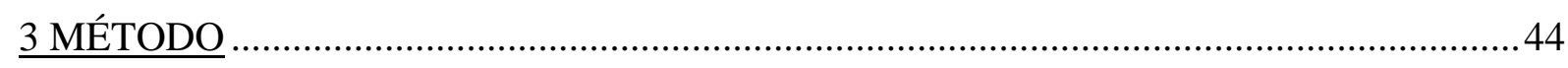

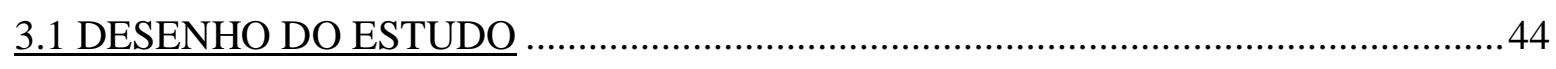

3.2 PRESSUPOSTOS TEÓRICOS E METODOLÓGICOS ..............................................44

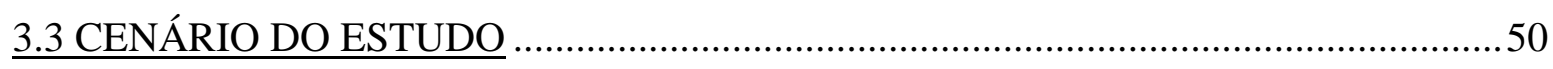

3.4 SUJEITOS DA PESQUISA E CARACTERIZAÇÃO DA AMOSTRA ........................52

3.5 FONTE DOS DADOS E INSTRUMENTO DE COLETA DE DADOS .......................52

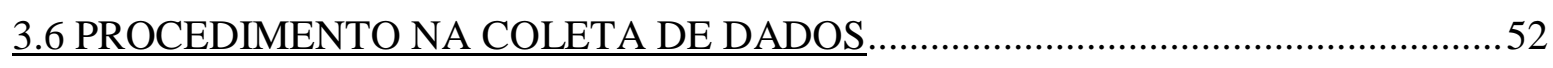

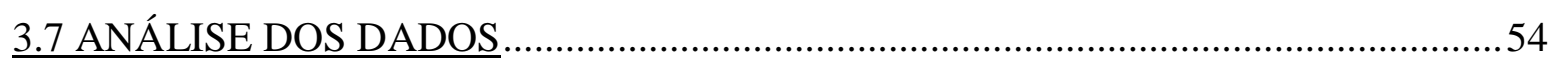

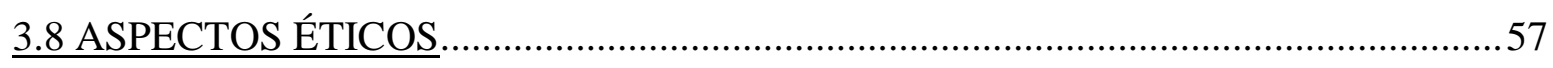

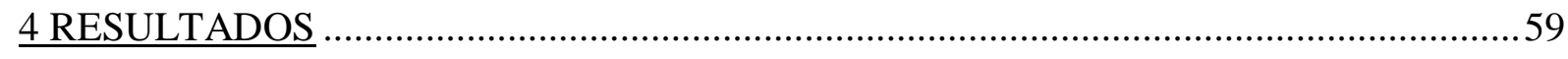

4.1 PERFIL SOCIOECONÔMICO E DE SAÚDE DAS VÍTIMAS DE

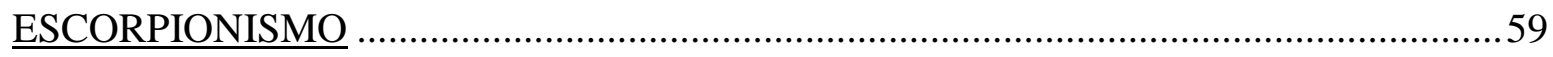

4.2 CARACTERIZAÇÃO EPIDEMIOLÓGICA DO ACIDENTE ESCORPIÔNICO .......62

4.3 CARACTERIZAÇÃO CLÍNICA DO ESCORPIONISMO ...........................................72

4.4 CARACTERIZAÇÃO TERAPÊUTICA DOS ACIDENTES ESCORPIÔNICOS .......95

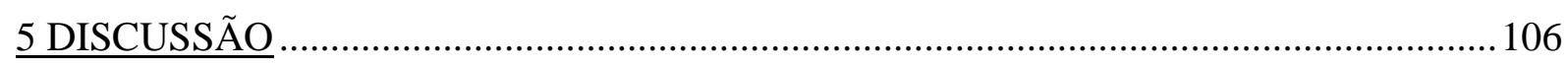

5. VULNERABILIDADE AOS ACIDENTES ESCORPIÔNICOS ....................................106

5.1 DIMENSÃO SINGULAR E MARCADORES DE VULNERABILIDADE

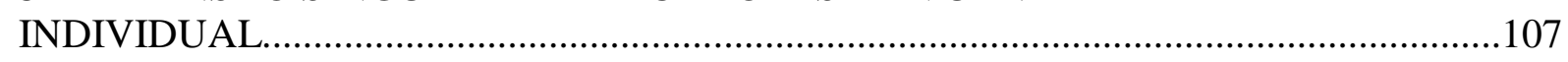

5.2 DIMENSÕES PARTICULAR E ESTRUTUTAL E MARCADORES DE

VULNERABILIDADE COLETIVA (PROGRAMÁTICO E SOCIAL................................121

5.3 PROPOSTA DE UMA MATRIZ DE ANÁLISE DA VULNERABILIDADE AOS

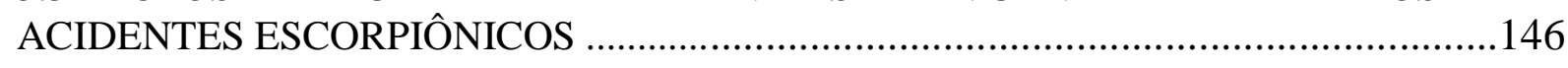

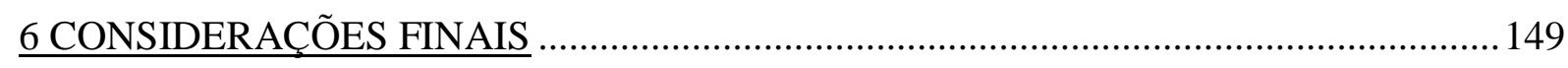

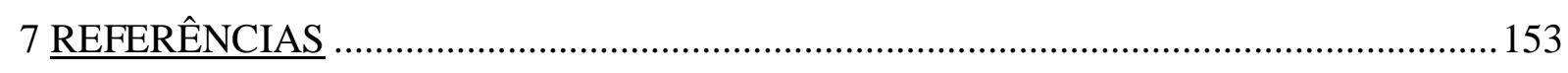

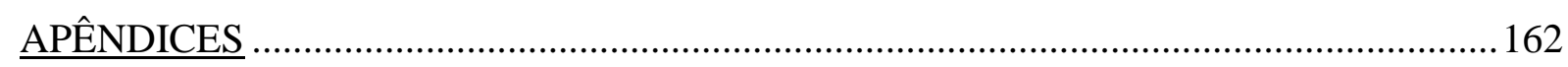

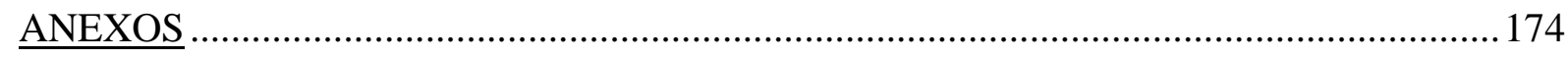




\section{APRESENTAÇÃO}

Nos últimos 14 anos atuando como enfermeira da cidade de Rurópolis lidava diariamente com acidentes por animal peçonhento, especialmente o escorpionismo. Esta é a realidade e o cotidiano dos profissionais de enfermagem, que são protagonistas do cuidado em todos os serviços de saúde, principalmente no interior da Amazônia.

$\mathrm{O}$ acidente por escorpião em Rurópolis se manifesta de forma peculiar, diferente de outras regiões do país. Esse fenômeno complexo e multidimensional instigou-me a repensar estratégias no âmbito dos serviços de saúde, das ações de prevenção na atenção primária à saúde e ao manejo clínico no contexto hospitalar, principalmente a partir do ano de 2010.

Ingressei na carreira docente em 2009 na Universidade do Estado do Pará, no curso de enfermagem. Como experiência acadêmica, orientei trabalhos de iniciação científica e de conclusão de curso abordando o tema "acidente escorpiônico".

No final de 2010, ingressei no Mestrado em Doenças Tropicais da Universidade Federal do Pará - UFPA em que estudei outro agravo negligenciado em populações quilombolas: o vírus linfotrópico de células T humanas - HTLV. Neste mesmo ano, o meu interesse em estudar o escorpionismo aumentou ao participar da equipe de coleta de dados para a Tese do Dr. Pedro Pereira de Oliveira Pardal, referência no assunto no Estado do Pará, que também investiga a peculiaridade do escorpionismo no oeste paraense.

Em 2015, ingressei no curso de Doutorado do Programa de Pós-Graduação em Enfermagem tendo como desafio, abordar este tema tão pouco estudado na ciência do cuidar e que requer maior compreensão. Atualmente, atuo membro do Núcleo de Medicina Tropical da Faculdade de Medicina da Universidade de São Paulo na cidade de Santarém e faço parte de grupos de pesquisas e de interesse voltados ao escorpionismo.

Esta tese ampliou meu olhar para o escorpionismo e sobre a vulnerabilidade em que a população e profissionais estão susceptíveis e os resultados deste já contribuíram e ainda contribuirão significativamente para mudanças nas políticas públicas municipais, principalmente no planejamento e reordenamento dos processos de trabalho nas unidades de saúde. Como gestora municipal da saúde, a partir desse conhecimento, espero minimizar significativamente a vulnerabilidade programática ao escorpionismo em Rurópolis. 


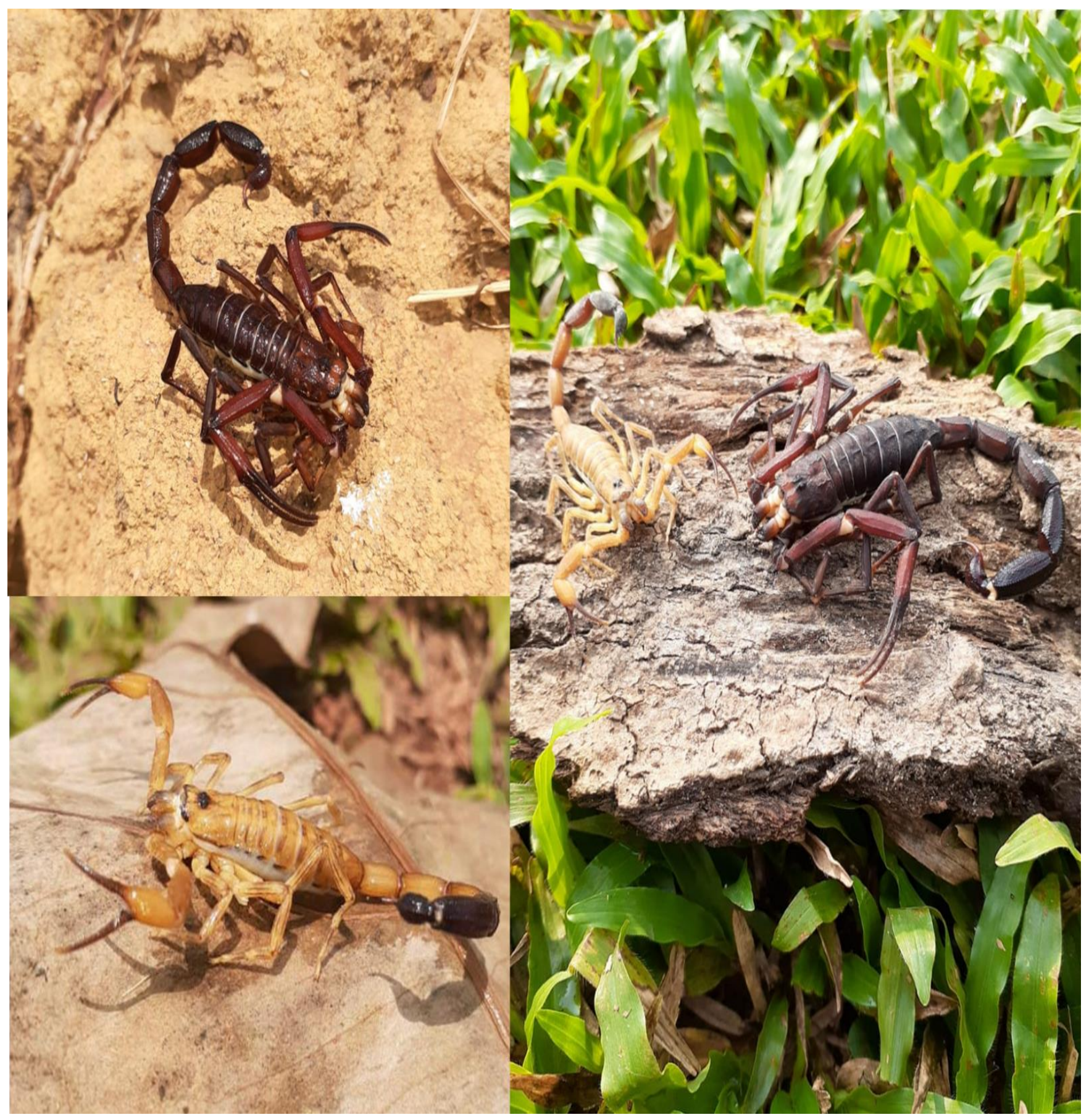




\section{INTRODUÇÃO}

Há interesse mundial de pesquisadores da área da saúde com os acidentes com escorpião, na perspectiva de que o conhecimento produzido, fomente políticas públicas de enfrentamento deste agravo e ações de prevenção e assistência aos indivíduos e coletivos. Particularmente na Enfermagem, o acidente com o escorpião é objeto de interesse para o cuidado individual e coletivo, exigindo-se que tenha por base as melhores evidências científicas para tal. O acidente por escorpião com ocorrência no estado do Pará é o interesse da presente investigação.

Abre-se com este capítulo, breve explanação sobre os escorpiões e sua distribuição, seguido da epidemiologia do escorpionismo e a fisiopatologia e a clínica do envenenamento.

\subsection{Os escorpiões e sua distribuição}

Os escorpiões são invertebrados pertencentes ao Filo Arthropoda (arthro: articuladas/podos: pés), classe Arachnida (por terem oito pernas) e ordem Scorpiones artrópodes (com patas formadas por vários segmentos) (BRASIL, 2009). Também conhecidos como lacraus em algumas regiões do Brasil, possuem existência comprovada há 450 milhões de anos no ambiente marinho (BROWNELL; POLIS, 2001 apud BRAZIL; PORTO, 2010).

A Ordem Scorpiones está presente em todos os continentes, com exceção da Antártida. Esta possui 18 famílias, 163 gêneros e cerca de 1500 espécies no mundo e possui suma importância clínica (BRAZIL; PORTO, 2010). As espécies mais nocivas ao ser humano pertencem às famílias Buthidade gênero centruroide (América Central), Tityus (América do Sul), Androctonus e Buthus (Norte da África), Buthotus e Leiurus (Oriente Médio) e Mesobuhus Tamulus (Índia) (LOURENÇO, 2002; LOURENÇO; EICKSTEDT, 2003; BRAZIL; PORTO, 2010; KHATTABI et al., 2011; FREITAS, 2011).

Os escorpiões estão presentes em todo continente americano. No Brasil, a escorpiofauna é representada por quatro famílias: Bothriuridae, Buthidae, Chactidae e Ischnuridae, abrangendo 17 gêneros e 94 espécies (BRAZIL; PORTO, 2010).

As regiões Norte e Nordeste possuem a maior riqueza de espécies de escorpiões do país. Há na região norte pouco mais da metade de espécies catalogadas no país, são 68 espécies distribuídas nos diversos estados. O Estado do Amazonas é aquele com maior número de espécies, com 38 catalogadas e, o Pará, o terceiro colocado com pouco menos de 20 espécies 
(BRAZIL; PORTO, 2010). Pesquisadores acreditam que a escorpiofauna brasileira ainda é subestimada pela carência de estudos nesta área.

Dentre as famílias de escorpiões, a família Buthidae reúne todas as espécies de importância clínica no mundo, cerca de 25 espécies. É a maior e mais distribuída família da ordem Scorpiones, com espécies de pequeno e médio porte (2 a $12 \mathrm{~cm}$ ). No Brasil, são 82 espécies de butídeos distribuídos em oito gêneros: Ananteris, Isometros, Microtityus, Phisoctonus, Rhopalurus, Tityus, Triglorhopalurus e Zabius. Com 54 espécies, o gênero Tityus é o que possui maior número catalogado entre os gêneros (BRAZIL; PORTO, 2010).

No Brasil, o gênero Tityus possui as principais espécies de interesse clínico, tem ampla distribuição em habitats naturais e possui alta capacidade de adaptação para colonizar ambientes antrópicos, por isso está presente em todas as regiões do país. O Tityus serrulatus é o maior responsável pelos acidentes devido sua ampla distribuição nas regiões Nordeste, Centro-Oeste, Sudeste e Sul. Outras espécies como o Tityus stigmurus (Nordeste), Tityus bahiensis (Sudeste) e o Tityus obscurus (Norte) também são de importância clínica nas diversas regiões do Brasil (BRASIL, 2001; BRASIL, 2009; BRAZIL; PORTO, 2010; LOURENÇO; EICKSTEDT, 2009; CHIPPAUX; GOYFFON, 2008).

Ainda são reconhecidas outras espécies de Tityus que causam envenamentos leves e moderados pelo país: T.adrianoi, T.brazilae, T. charreyroni, T. confluens, T.costatus, T.fasciolatus, T.mattogrossensis, T.metuendus, T. neglectus, T.pusillus, T.trivittatus, T.silvestris e T.apiacas. Outras espécies de outros gêneros também causam acidentes leves e moderados como Ananteris spp., Isometrus maculatus, Rhopalurus agamemnom e Rhopalurus rochai (BRAZIL; PORTO, 2010).

Os escorpiões podem ser encontrados em praticamente todos os ecossistemas terrestres, apesar de algumas espécies possuírem condições específicas para sobreviverem em ambientes peculiares. A maioria vive em ambientes naturais como florestas, matas, cavernas, porém algumas espécies podem se adaptar em ambientes periurbanos e urbanos, em busca de abrigo e alimentos, principalmente próximo de residências humanas (BRAZIL; PORTO, 2010; LOURENÇO; EICKSTEDT, 2009).

Sobre o animal, seu corpo dividido em cefalotórax ou carapaça (prossoma) e abdômen (opistossoma), que se divide em tronco (mesossoma) e cauda (metassoma) (BRASIL,2009).

O cefalotórax possui apêndices como quelíceras, pernas e pedipalpos. As quelíceras são trituradoras de alimentos, as pernas fazem a locomoção e elevação do corpo e os pedipalpos imobilizam a presa, realizam defesa, atuam na percepção sensorial e também auxiliam no momento da reprodução sexuada. É cefalotórax é coberto dorsalmente por uma carapaça que 
sustenta os olhos medianos e laterais que são fotossensíveis e eficientes para os hábitos noturnos do animal (BRAZIL; PORTO, 2010; BRASIL, 2009).

O tronco contém as estruturas reprodutivas, como o opérculo genital, os apêndices sensoriais e espiráculos que são aberturas externas dos pulmões. A cauda possui na sua extremidade, o telson que é composto pela vesícula ou ferrão, que faz a inoculação do veneno durante o acidente escorpiônico (BRASIL, 2009; BRAZIL; PORTO, 2010) (Figura 01).

Figura 01 - Morfologia do escorpião.

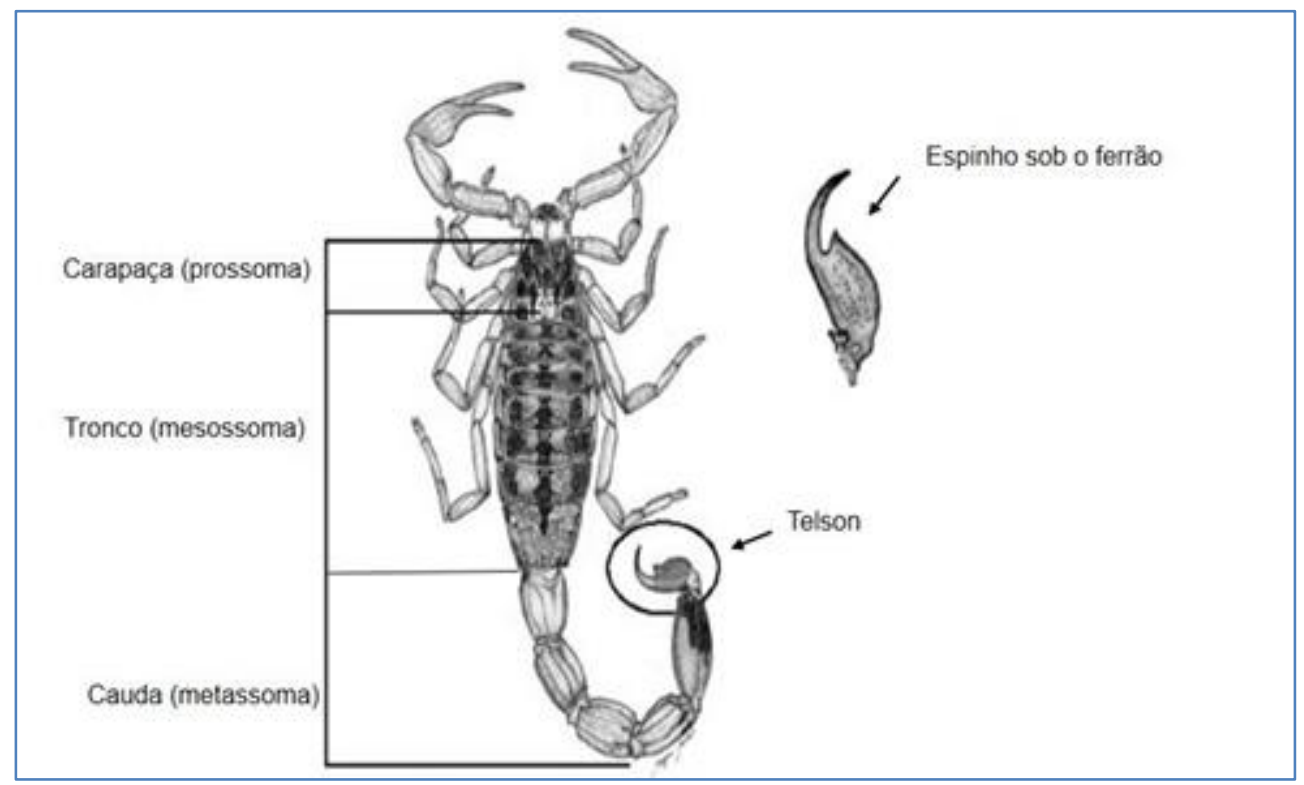

Fonte: Brasil, Ministério da Saúde. Secretaria de Vigilância em Saúde. Departamento de Vigilância Epidemiológica. Manual de controle de escorpiões. Brasília: Ministério da Saúde, 2009.

Esses artrópodes possuem pulmões foliáceos com respiração exclusivamente aérea, olhos simples e oito pernas locomotoras. Em sua superfície possuem pelos, pentes, um sistema de orientação espacial nas pernas e células nervosas fotossensíveis que lhes garantem a sobrevivência nos diversos ecossistemas. O tamanho desses escorpiões varia de 0,8 até $21 \mathrm{~cm}$, sendo a média de 2 a 9 cm entre as espécies brasileiras (BRAZIL; PORTO, 2010).

Alguns escorpiões podem se reproduzir assexuadamente por partenogênese, a exemplo do T.serrulatus, onde os óvulos se desenvolvem sem fecundação de um macho. No entanto, a maioria se reproduz de forma sexuada, cujo comportamento de corte é dividido em três fases: a iniciação, a dança e a transferência de espermatozoides (BRAZIL; PORTO, 2010).

$\mathrm{Na}$ iniciação, ocorre o encontro e o reconhecimento sexual e, se a fêmea estiver receptiva, prossegue-se para dança onde macho conduz a fêmea segurando seus pedipalpos para efetuar a deposição do espermatóforo. Na transferência de espermatozóides, o macho coloca o 
espermatóforo no substrato escolhido e posiciona a fêmea sobre ele, promovendo a abertura do opérculo genital com entrada dos espermatozóides e, consequentemente, fecundação (BRAZIL; PORTO, 2010).

São animais vivíparos e o período da gestação é variado, inclusive de espécies de reprodução sexuada e assexuada, mas em geral possui duração de três meses para o gênero Tityus. Há relatos de que eles podem gerar de 1 a 105 filhotes que irão se manter no dorso da mãe até a primeira ou segunda muda, quando se dispersam. O período entre o nascimento e dispersão dos filhotes pode levar de 5 a 30 dias, conforme espécie. O seu crescimento é dependente de fatores como temperatura, disponibilidade de alimento e reprodução. A maioria das espécies vive entre 2 e 10 anos, mas alguns escorpiões podem chegar a viver 25 anos (BRASIL, 2009; BRAZIL; PORTO, 2010).

O escorpião preto da Amazônia, o T. obscurus, sinônimo de $T$. paraensis e $T$. cambridgei, é responsável por acidentes clinicamente importantes nos estados do Pará, Amapá e Mato Grosso. Ele possui cerca de $9 \mathrm{~cm}$ de comprimento, quando adulto é todo negro e os machos possuem pedipalpos mais finos e longos do que na fêmea. Quando jovem, o T. obscurus apresenta uma coloração castanha manchada de escuro no corpo e apêndices, podendo ser confundido com outras espécies da Região (PARDAL et al., 2014; BRASIL, 2009; BRAZIL; PORTO, 2010).

Figura 02 - Exemplares adultos de Tityus obscurus que causaram acidentes em Rurópolis, Pará. a) Escorpião macho; b) Escorpião Fêmea.

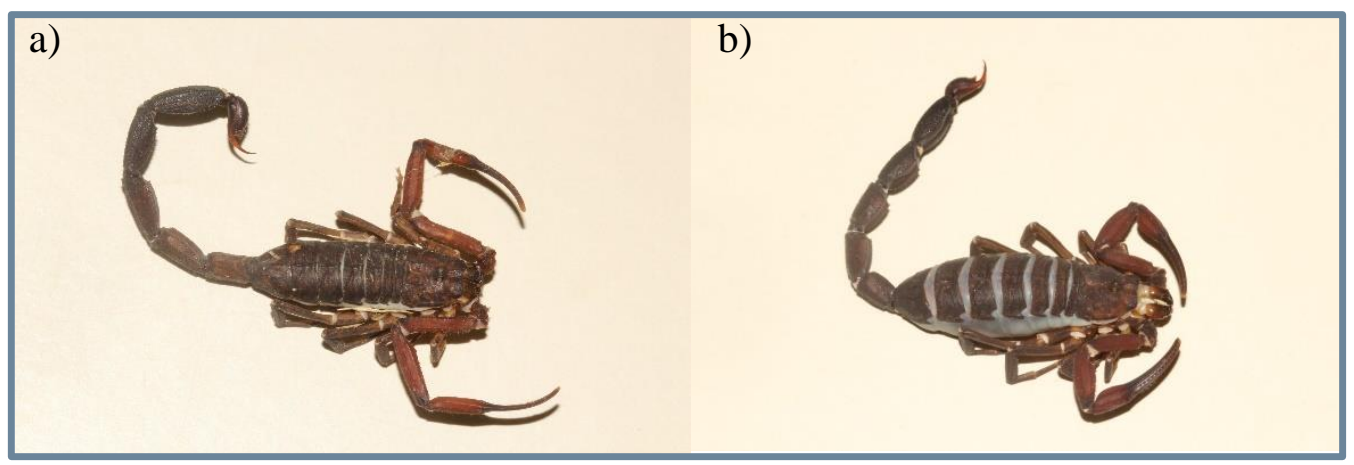

Fonte: Bertani, R. Laboratório Especial de Ecologia e Evolução, Instituto Butantan, São Paulo, 2017.

Para Polis (1990), os escorpiões são animais terrestres que preferem lugares secos ou úmidos e podem ser encontrados nos mais diversos locais, que variam desde desertos até florestas. Vivem frequentemente sob as folhas, pedras, madeiras, em fendas de rochas, enfim entulhos de qualquer natureza. Os escorpiões, na maioria das espécies, possuem hábitos 
noturnos e durante o dia preferem ficar escondidos. São animais que sobrevivem em condições físicas extremas e adversas alimentando-se de pequenos insetos (AMITAI, 1998).

Os escorpiões são encontrados em todos os ecossistemas terrestres, com exceção da tundra, taiga de alta latitude, áreas boreais e em algumas áreas de elevada altitude. Já foram registrados a mais de $5.500 \mathrm{~m}$ de altitude (Andes peruanos), dentro de cavernas sem luz, sob pedras cobertas de neve e dos desertos mais áridos até as florestas mais úmidas (POLIS, 1990).

A maioria das espécies apresenta exigências específicas com relação ao hábitat e microhabitat e possuem padrões ecológicos e biogeográficos previsíveis e localizados. No entanto, algumas espécies do gênero Centruroides, Isometrus, Tityus, Euscorpius e Bothriurus apresentam alta mobilidade ecológica e padrões irregulares de distribuição, sendo encontradas em ambientes modificados pela ação do homem, onde se instalam e se alimentam dentro e/ou próximo das áreas de residências humanas (LOURENÇO; EICKSTEDT, 2009).

São carnívoros, alimentando-se exclusivamente de animais vivos, como insetos e pequenos vertebrados, e quando ocorre escassez completa de alimento, praticam o canibalismo para sobreviver. Logo, quando o local não possui saneamento básico, entulhos e lixos, atraem esses animais e predispõem ao aparecimento de escorpiões nessas regiões (MATTHIESEN, 1984).

Entre os predadores naturais de escorpiões estão insetos, mamíferos e aves, como as lacraias, louva-deus, macacos, aranhas, corujas, gaviões, quatis, galinhas, camundongos, algumas formigas e os próprios escorpiões. No entanto, alterações ambientais provocadas pelo homem, como desmatamento, utilização indiscriminada de agrotóxicos e crescimento urbano desordenado, parecem ser as principais causas de extermínio dos escorpiões (CRUZ, 1994).

\subsection{A epidemiologia do escorpionismo}

A epidemiologia dos acidentes escorpiônicos no mundo ainda não é bem conhecida, pois existem consideráveis variações geográficas, ao nível tanto da incidência e gravidade o que não permite que se tenham dados tão concretos relacionados a esse problema (CHIPPAUX; GOYFFON, 2008).

Os escorpiões são responsáveis por cerca de 1,2 milhões de acidentes em todo o mundo, levando 3.250 acidentados ao óbito por ano. O escorpionismo ocorre em todos os continentes, com exceção da Antártida, e é um problema de saúde pública em muitos países tropicais e subtropicais, especialmente no Norte da África, Sul da Índia, América Latina e Oriente Médio. 
Na Europa, na Austrália e nas Ilhas do Pacífico os dados epidemiológicos são escassos (CHIPPAUX; GOYFFON, 2008).

$\mathrm{Na}$ Europa se tem poucos dados, uma vez que as espécies que lá são encontradas não apresentam riscos tão agressivos para o ser humano e os casos que ocorrem são classificados como leve. No Sul da França, anualmente ocorrem cerca de 5 casos a cada 100.000 Habitantes (CHIPPAUX; GOYFFON, 2008; DE HARO; POMMIER, 2003).

No Norte da África, na Tunísia, a incidência anual de acidentes por escorpião é de 420 por 100.000 habitantes, porém na província de Sidi Bouzid, no centro do país, a incidência é mais elevada, variando entre 1.280 e 1.500 picadas por 100.000 habitantes. Na Argélia, ocorrem cerca de 170 casos e no Marrocos cerca de 50 casos a cada 100.000 habitantes. Na África Subsaariana a incidência de picadas de escorpião é baixa e são benignas. No Oriente médio, nas áreas rurais da Arábia Saudita, a incidência pode exceder 1.000 picadas de escorpião por 100.000 habitantes (CHIPPAUX; GOYFFON, 2008; SOULAYMANI-BENCHEIKH et al., 2002; BENGUEDDA et al., 2002; NJAH et al., 2001).

Na Ásia, da Birmânia para a Coréia e Japão, não foram encontrados dados epidemiológicos que sugiram que o escorpionismo seja um problema considerado de saúde pública, ou seja, com dimensões populacionais. No Irã, a incidência anual é de 140 acidentes por 100.000 habitantes. Na Índia, embora não se tenha conhecimento sobre os dados epidemiológicos da incidência, a fatalidade dos acidentes no país é constantemente citada (CHIPPAUX; GOYFFON, 2008; PIPELZADEH et al., 2007).

Na América do Norte, o número de chamadas recebidas pelos centros de intoxicações varia entre 15.000 e 16.000 por ano. As picadas por escorpião são muito frequentes nos estados do sul dos Estados Unidos, em particular Texas e Arizona, onde a incidência anual é de 22 por 100.000 habitantes (FORRESTER; STANLEY, 2004).

Na América Latina, existem países com regiões com altas incidências como os estados do centro-oeste do México, onde ocorrem em média 1350 picadas de escorpião por 100.000 habitantes, e em alguns locais do Chile, durante o verão, onde há incidências superiores a 1000 picadas por 100.000 habitantes, principalmente em domicílios suburbanos (CHOWELL et al., 2006).

$\mathrm{Na}$ Venezuela, a área de escorpionismo cobre todo o norte do país, a incidência média anual é de 40 picadas por 100.000 habitantes. Na Argentina, a distribuição geográfica é muito heterogênea e a maior incidência anual é de 26 acidentes por 100.000 habitantes. No norte da Colômbia, a incidência média anual é de 5 por 100.000 habitantes (MEJÍAS et al., 2007; SCHENONE; FONTECILLA, 1998; OTERO et al., 2004). 
No Brasil, o acidente escorpiônico se tornou agravo de notificação compulsória em 1997, pelo Sistema Informação de Agravos de Notificação (SINAN). Desde então, percebeuse que tem crescido consideravelmente, mostrando-se como o acidente por animal peçonhento de maior crescimento, tendo uma elevada letalidade em crianças, com maior incidência na Região Nordeste, acometendo em sua maioria pessoas em faixa etária economicamente ativa (RECKZIEGEL, 2013).

Dados do SINAN revelam que, no período de 2007 a 2017, foram notificados 770.891 acidentes escorpiônicos no Brasil e destes 33.978 aconteceram na região norte. No período, o Estado do Pará notificou 18.487 casos, o que corresponde a 54,41\% dos casos da região.

Assim como no mundo, no Brasil, tanto pela alta incidência quanto pela gravidade dos casos, o envenenamento por escorpião representa uma questão de saúde que não pode ser negligenciada. Entre os anos de 2000 a 2010, foram notificados 359.427 acidentes, dos quais 561 foram ao óbito, com incidência de 17,7 acidentes para cada 100 mil habitantes. A maioria dos acidentados foram pessoas do sexo masculino, de raça/cor negra, na faixa etária de 20 a 49 anos, nos meses de outubro a janeiro, na zona urbana, evoluindo para cura. Os casos de óbitos estão associados à faixa etária pediátrica (RECKZIEGEL, 2013; BRASIL, 2009).

A média nacional de letalidade é de $0,17 \%$, sendo que alguns estados como Rondônia $0,71 \%$, Tocantins $0,24 \%$, Mato Grosso $0,31 \%$ e Pará $0,24 \%$, apresentam índices de letalidade maiores. A maioria dos casos tem curso benigno e, em aproximadamente $65 \%$ dos casos, o local da picada atinge os membros superiores, mão e antebraço (BRASIL, 2009; BRASIL, 2001).

As maiores frequências de casos e óbitos e taxas médias anuais de incidência e mortalidade foram registradas nas Regiões Nordeste e Sudeste do País, porém as maiores taxas médias anuais de letalidade foram registradas nas Regiões Centro-Oeste e Norte. Na Região Norte do País, onde se foca o estudo, observou-se o predomínio de acidentes nos meses de junho e julho, em zonas rurais. A taxa de incidência foi maior em indivíduos de 65 anos de idade ou mais, sendo maior a taxa de letalidade em crianças de até 9 anos de idade (RECKZIEGEL, 2013).

Na região norte, no período de 2000 a 2010, foram 11,4 acidentes/100.000 habitantes e 39 óbitos e o Estado do Pará, localidade da presente investigação, apresentou incidência de 15,2 acidentes/100.000 habitantes e um total de 31 óbitos, o que representa cerca de $80 \%$ do total de óbitos por estas causas notificados na região norte. Quanto à letalidade no Pará é semelhante à média nacional e a gravidade muda em função da mesorregião. (BRASIL, 2010; BRASIL, 2011; MAESTRI NETO et al., 2008). 
Segundo o SINAN, no período de 2007 a 2017, em Rurópolis foram notificados 940 casos de acidente escorpiônico, sendo 107 destes pacientes oriundos de outros municípios, como Placas e Aveiro. Os anos com maior prevalência foram 2012 e 2013 com 110 casos cada, com $(74,4 \%)$ acidentes ocorridos na zona rural. Os meses de julho e agosto foram os mais incidentes com $(22,9 \%)$ dos casos, sendo que em $(26,7 \%)$ destes o membro superior (mão e dedo da mão) foi o local mais afetado com $(45,5 \%)$. Do total, $(65,7 \%)$ das vítimas foram do sexo masculino, $(48,8 \%)$ com idade entre 20 a 49 anos e $(64,74 \%)$ se consideravam pardos. Não houve letalidade no período.

\subsection{A fisiopatologia e a clínica do envenenamento}

A toxicidade do veneno é diferente para cada espécie de escorpião. $\mathrm{O}$ veneno, em contato com o organismo produz diversos efeitos que podem variar de leve dor, parestesia, edema, eritema, entre outros, até neurotoxicidade sistêmica grave, que pode levar a atividade neuromuscular intensa e descoordenada, depressão miocárdica, insuficiência respiratória e a morte por falência de órgãos (BRASIL, 2009; CUPO; AZEVEDO-MARQUES; HERING, 2009; LOURENÇO; EICKSTEDT, 2009; ISBISTER; BAWASKAR, 2014).

Os escorpiões são considerados animais peçonhentos porque produzem substância tóxica e apresentam um aparelho especializado para inoculação desta, ressaltando-se que todos os escorpiões possuem veneno e a capacidade de injetá-lo. A finalidade da inoculação dessas toxinas é matar ou paralisar suas presas, auxiliar na digestão desses alimentos e mecanismo defesa contra predadores (BRAZIL; PORTO, 2010).

O veneno de escorpião é uma mistura complexa de proteínas de baixo peso molecular, mais de 70 aminoácidos, mucopolissacarídeos, fosfolipase, hialuronidase, serotonina, histamina, inibidores enzimáticos, peptídeos neurotóxicos, sais, lipídeos e nucleotídeos. Têm, pelo menos, uma centena de diferentes componentes que atuam em sítios específicos de canais de sódio, potássio e cálcio. O reconhecimento de canais iônicos faz com que ocorra uma cascata de efeitos fisiológicos e promove eventos moleculares secundárias associados ao efeito fisiológico de toxinas de escorpião (PETRICEVICH, 2010; BRAZIL; PORTO, 2010; TORREZ, 2015).

As pesquisas sobre a composição dos venenos de escorpião geralmente concentraramse em peptideos que contem ligações dissulfureto (toxinas) e proteínas grandes. As ligações curtas, lineares, peptideos que não contem ligações dissulfureto (NDBPs) foram poucos 
pesquisados e podem representar respostas para complexidade de manifestações clínicas que ainda não foram bem esclarecidas. No entanto, seus componentes são altamente tóxicos, podendo causar disfunção significativa dos sistemas nervoso, cardiovascular e muscular (DIAS et al., 2017).

O veneno escorpiônico é semelhante, mesmo em espécies diferentes. Dentre os compostos, existem diferentes toxinas que atuam sobre receptores de membranas de células que atuam principalmente em canais de sódio e potássio e também sobre canais de cloreto e cálcio, causando um aumento na liberação de acetilcolina, noradrenalina e adrenalina, afetando os sistemas simpático e parassimpático. Desta forma, as neurotoxinas são responsáveis pela maioria dos sinais e sintomas observados no envenenamento por escorpião (POSSANI, 1999; GUERRERO-VARGAS et al., 2012; DÁVILA; DÁVILA; DONIS, 2002; VASCONCELOS et al., 2005; PINTO et al., 2010).

No entanto, pouco se sabe sobre o veneno de escorpiões do norte do Brasil, principalmente sobre $T$. obscurus, que é o maior responsável pelos casos ocorridos na Amazônia. Sabe-se que, até o momento, foram descritos 102 componentes peptídicos onde apenas 18 deles eram conhecidos, sendo três específicos para canais de potássio e 15 para canais de sódio (DE PAULA SANTOS-DA-SILVA et al., 2017; GUERRERO-VARGAS et al., 2012).

As toxinas inicialmente foram denominadas de Tc por fazer referência à Tityus cambridgei, por isso as três toxinas específicas para canais de potássio foram denominadas de Tc49b, a Tc48a e a Tc48b/Tc49a que, posteriormente, foram denominadas de To (Tityus obscurus), seguindo a numeração crescente de 1 a 3, respectivamente, To1 To2 e To3. A To1 (Tc49b), dependendo de sua concentração e em modelos experimentais (ratos), pode abolir a corrente de sódio das membranas das células granulares do cerebelo (BATISTA et al., 2002; BATISTA et al., 2004; MURGIA et al., 2004; GUERRERO-VARGAS et al., 2012).

As 15 toxinas que atuam em canais de sódio explicam a maioria dos efeitos farmacológicos do envenenamento, pois estes decorrem da despolarização das membranas das células excitáveis do organismo (GUERRERO-VARGAS et al., 2012; TORREZ, 2016).

Estas neurotoxinas são peptídeos de baixo peso molecular que especificamente modulam a permeabilidade de vários canais iônicos de células excitáveis e não excitáveis, responsáveis pelos sintomas dos envenenados (GUERRERO-VARGAS et al., 2012).

Sabe-se também que aproximadamente 5\% do veneno desta espécie é composto NDBPs. Em um estudo recente, cerca de 320 desses peptideos foram detectados, dos quais 27 foram sequenciados. Entre eles, 13 foram classificados como novas toxinas no veneno de $T$. 
obscurus. Alguns dos novos peptídeos mostraram-se toxinas multifuncionais que podem causar dor, formação de edema, hemólise e inflamação (DIAS et al., 2017).

Ao entrarem em contato com o veneno do escorpião os indivíduos podem reagir clinicamente de formas diferenciadas, dependendo de sua constituição corpórea, idade ou quantidade de veneno inoculado. Alguns podem sentir apenas dor local ou outros podem evoluir ao óbito. A gravidade do envenenamento depende da quantidade de peçonha inoculada, da constituição corpórea do acidentado e dos mediadores químicos liberados (BRASIL, 2009; GUERRERO-VARGAS et al., 2012).

A evolução clínica e a gravidade desses acidentes estão relacionadas a alguns aspectos do envenenamento e do pós-acidente. Os aspectos relacionados ao processo de envenenamento são: espécie e tamanho do escorpião; quantidade de veneno inoculado e sua concentração no sangue; idade e tamanho da vítima; e sensibilidade ao veneno. Os aspectos pós-acidentais estão associados ao atendimento como tempo entre o acidente/atendimento clínico, administração precoce do antiveneno e a manutenção das funções vitais da vítima (CAMPOLINA, 2013).

As manifestações clínicas podem ser locais ou sistêmicas. A dor local, de intensidade variável, é característica da maioria dos casos e pode ser acompanhada de edema, eritema, sendo difícil a visualização da marca do ferrão. Essa dor surge minutos após a picada e evolui de forma benigna na maioria dos casos e, desta forma, sem a necessidade do uso da antiveneno. Esses casos leves, além da sintomatologia local e a agitação podem ocorrer devido ansiedade causada pelo acidente (BRASIL, 2009; TORREZ et al., 2015; RECKZIEGEL, 2013).

Nos casos de manifestações sistêmicas, dependendo da intensidade dos sinais e sintomas, os casos moderados podem apresentar náuseas, vômitos (sinal preditor de gravidade), dor abdominal, cólicas, diarreia, febre, sudorese. Em quadros clínicos graves, o desequilíbrio entre os sistemas nervoso simpático e parassimpático, se expressa inicialmente com sudorese profusa, agitação psicomotora, hipertensão e insuficiência cardíaca congestiva aguda. No entanto, a gravidade está relacionada também a composição do veneno, com os efeitos sintéticos da espécie e a faixa etária da vítima, pois crianças com menos de cinco anos de idade e os idosos são mais gravemente afetados (BRASIL, 2009; CHIPPAUX; GOYFFON, 2008; TORREZ et al., 2015).

No âmbito internacional, um grupo de especialistas internacionais em escorpionismo se reuniu e elaborou um consenso clínico sobre a gravidade dos acidentes, dividindo-os em classes I, II e III. A classe I corresponde aos casos com manifestações clínicas restritas ao local de inoculação do veneno. A classe II corresponde às manifestações sistêmicas que não oferecem 
risco de vida e a classe III estão as manifestações sistêmicas que impõem riscos à vida do paciente (KHATTABI et al., 2011). 
Quadro 01: Classificação de gravidade clínica das vítimas de escorpionismo, 2011.

\begin{tabular}{ll}
\hline CLASSIFICAÇÃO & \multicolumn{1}{c}{ MANIFESTAÇÕES CLÍNICAS } \\
\hline Classe I & Manifestações clínicas locais \\
& $\begin{array}{l}\text { Erupção bolhosa, sensação de queimadura (ardor), equimose, eritema, } \\
\text { hiperestesia, prurido, necrose, parestesia, dor, púrpura/petéquias, edema e } \\
\text { formigamento. }\end{array}$
\end{tabular}

Classe II Manifestações clínicas sistêmicas não ameaçadoras da vida

Distensão abdominal, agitação/inquietação/excitação, anisocoria, artralgia, ataxia, confusão, convulsão, diarreia, boca seca, distonia, encefalopatia, fasciculação, hemorragia gastrointestinal, hematúria, cefaleia, hipertensão, hipertermia, hipotermia, lacrimejamento, cãibras musculares locais, miose, midríase, mioclonia, náusea, nistagmo, odinofagia, palidez, pancreatite, parestesia geral, priaprismo, prostração, ptose, rinorréia, salivação, sonolência/letargia, estridor, sudorese, taquicardia, sede, retenção urinária, vômitos e sibilos.

Classe III Manifestações clínicas sistêmicas ameaçadoras da vida

Presença de, pelo menos, um dos seguintes sinais:

- Insuficiência Cardíaca: hipotensão, arritmia cardíaca, bradicardia e/ou colapso vascular.

- Insuficiência Respiratória: cianose, dispneia e/ou edema pulmonar.

- Falência Neurológica: Glasglow $\leq 6$ (sem sedação) e/ou paralisia.

Fonte: Khattabi et al., 2011. Classification of clinical consequences of scorpion stings: consensus development. Transactions of the Royal Society of Tropical Medicine and Hygiene. p.364, 2011.

Em casos de envenenamento por escorpião, dependendo da gravidade, o tratamento pode ser sintomático, específico e de suporte. No caso de tratamento sintomático, dependendo da intensidade da dor, podem ser indicados analgésicos sistêmicos, por via oral ou parenteral. Em casos de dor intensa, pode ser realizado bloqueio anestésico com infiltração local de Lidocaína $2 \%$ ou Bupivacaína 0,5\%, sem vasoconstritor, 3 a $4 \mathrm{ml}$ em adultos e 1 a $2 \mathrm{ml}$ em crianças (RECKZIEGEL, 2013).

Segundo o Manual de Diagnóstico e Tratamento de Acidentes por Animais Peçonhentos, os acidentes escorpiônicos são classificados clinicamente como leves, moderados ou graves, de acordo com a intensidade das manifestações clínicas apresentadas. No tratamento específico, a antiveneno está indicada para os casos grave e moderado com o soro antiescorpiônico (SAESC) ou o soro antiaracnídico (SAAR), devendo ser administrado precocemente, conforme descrito na Nota Técnica do Ministério da Saúde de 2016, apresentada na Figura 03 (BRASIL, 2001; BRASIL, 2016). 
Figura 03: Classificação dos acidentes escorpiônicos quanto à gravidade, manifestações clínicas e tratamento específico.

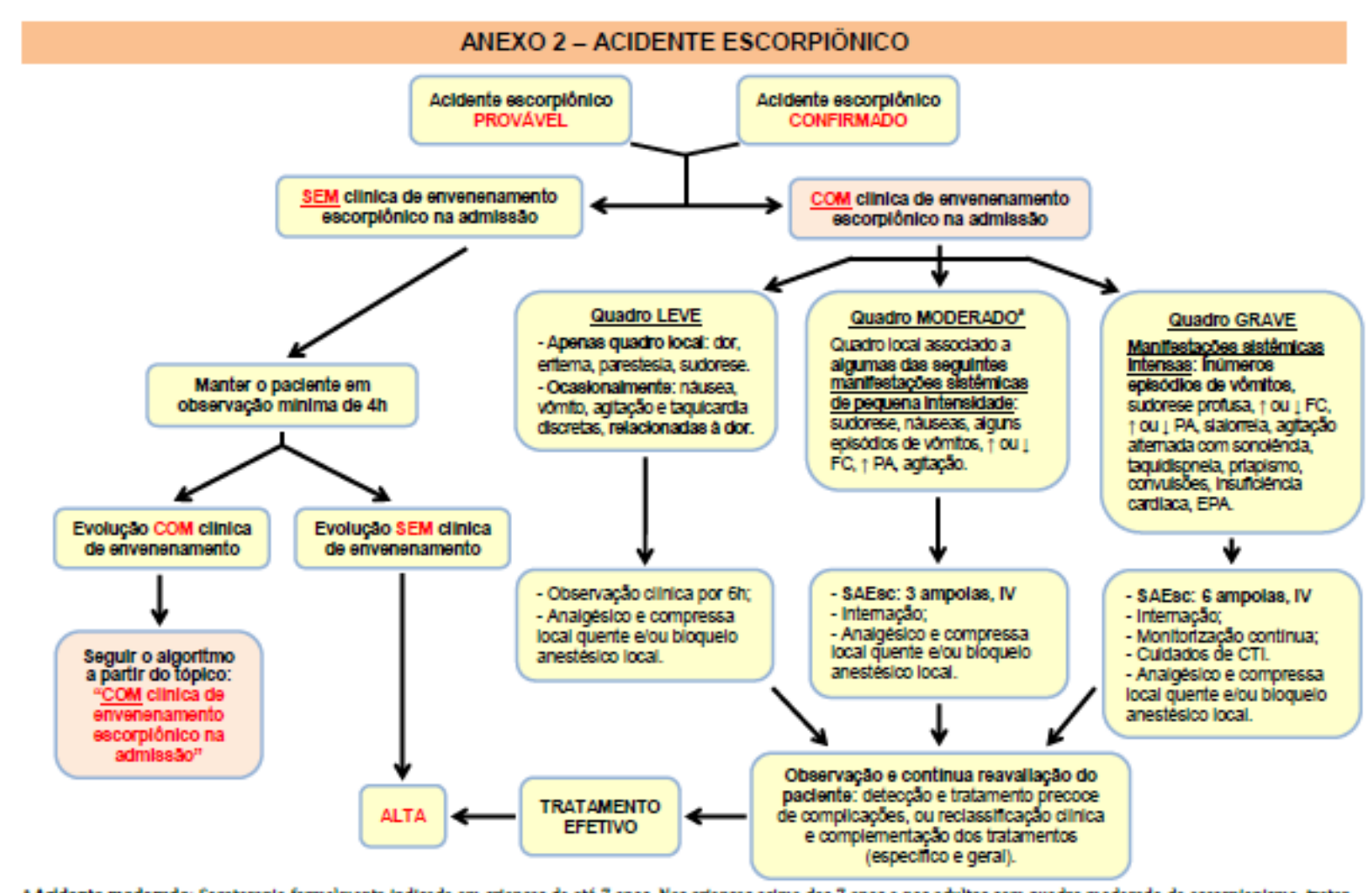

- Acidente moderado: Soroterapla formalmente indicada em crianças de ate 7 anos. Nas crianças acima dos 7 anos e nos adultos com quadro moderado de escorpionismo, tratar Inicialmente a dor e avallar o paciente. Se persistirem as manifestaçbes sistetemicas mesmo após a analgesia, iniclar soroterapla.

IMPORTASTE: Todo paciente submetido a tratamento soroteríploo deve flcar em observachio por, po minimo, 24h.

Legendat SAEsc - Soro antiescorpiSnico; IV - Intravenoso; PA - Pressäo arterial; FC - Frequetncla cardiaca; EPA - Edema Pulmonar Agudo; CTI - Centro de Terapla Intensiva.

OBS: Na falta do SAEsc, utlilzar o SMA [soro antlaracnidloo (Laxosceles, Fhoneutria e Tityw)].

Fonte: BRASIL. Portal da Saúde [Internet]. Nota Informativa: Informações da Coordenação-Geral de Doenças

Transmissíveis (CGDT) referentes à nova abordagem ao tratamento em casos de acidentes por serpentes do grupo Bothrops (“jararacas”) e por escorpiões, em situação de escassez de antivenenos, 2016.

É preciso considerar, que esta classificação não corresponde exatamente ao que se observa na prática clínica, dada a complexidade e diversidade com que se apresentam as manifestações clínicas, particularmente na Amazônia.

As manifestações clínicas do escorpionismo na região amazônica, especialmente no estado do Pará, onde são mais frequentes, ocorrem com comprometimento neuromuscular singular, não sendo observadas em outras regiões do Brasil. Especificamente nos municípios da região oeste do Pará, como Santarém, Rurópolis, Belterra, Aveiro, Itaituba, Novo Progresso, Monte Alegre, Altamira e Brasil Novo (PARDAL et al., 2003; PARDAL et al., 2014; TORREZ et al., 2015).

Na Amazônia, o escorpionismo é uma realidade cotidiana dos profissionais de saúde, porém poucos perceberam a peculiaridade do comportamento clínico deste acidente na região, seja por falta de atualização dos manuais do Ministério da Saúde, seja pela escassez de pesquisas publicadas ou mesmo pela deficiência desse conteúdo na academia. 
No interesse da presente pesquisa, na prática do Enfermeiro que atua nos acidentes nos serviços de assistência em municípios do Estado do Pará, têm se notado formas clínicas diferentes das comumente descritas. No município de Santarém, Torrez (2016) relatou 56 casos de escorpionismo onde a maioria apresentou disfunção cerebelar aguda e 94,6\% (53) queixouse de sensação de "choque elétrico" que se manifestou de forma local, regional e sistêmica. Em Igarapé Miri (Leste), Pardal et al. (2014) descreveram um acidente escorpiônico onde não foi observado este citado quadro clinico, apesar de serem todos os casos atribuídos ao Tityus obscurus. Porém, nas duas regiões, as enzimas musculares sofreram alterações, indicando uma possível lesão dos músculos esqueléticos, o que pode levar a rabdomiólise e, consequentemente, injúrias renais (TORREZ et al., 2015).

Figura 04 - Classificação da gravidade do acidente escorpiônico, segundo o Manual de Rotinas: Acidentes por Animais Peçonhentos.

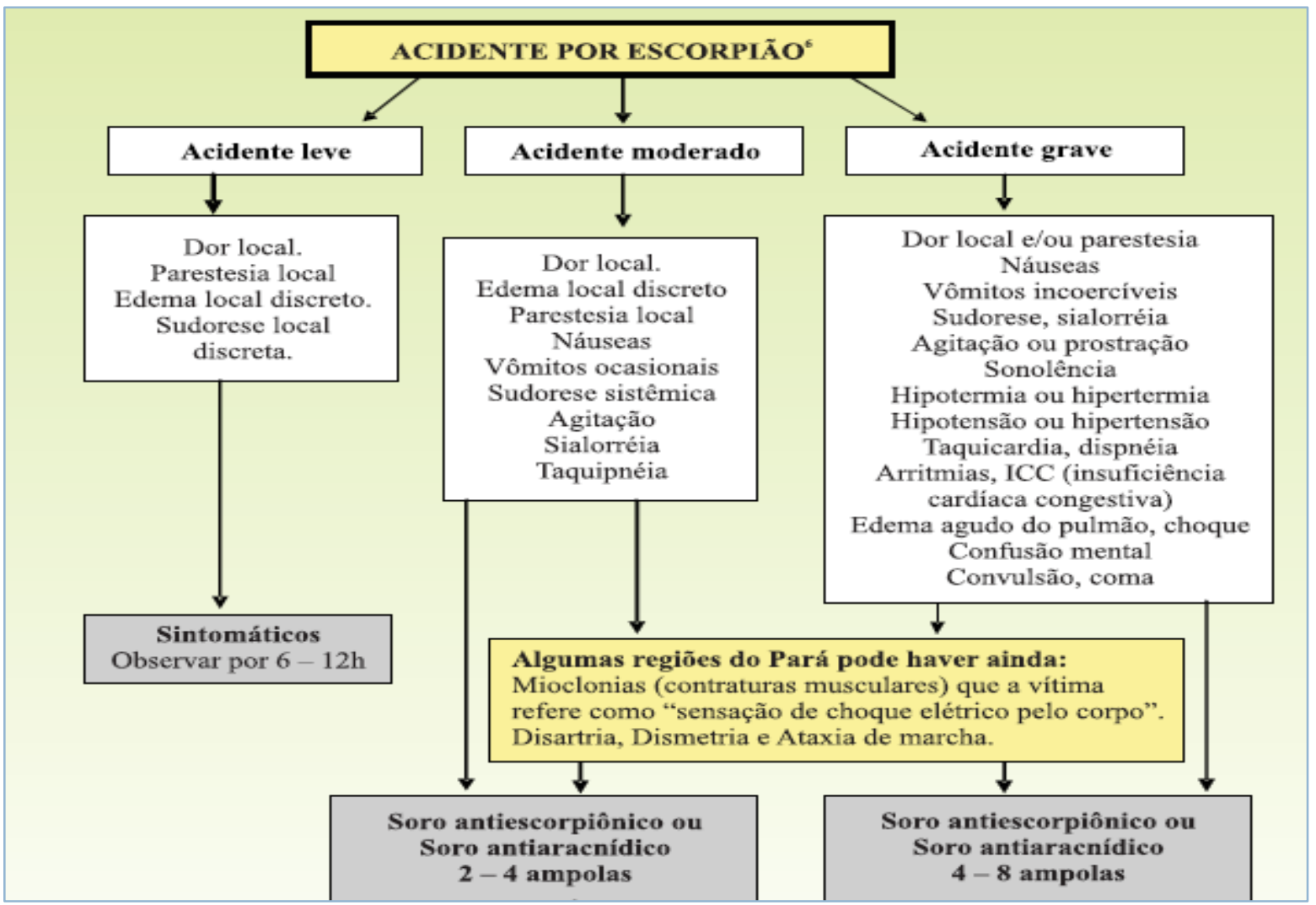

Fonte: Pardal P. P. O; Gadelha M. A. C. Acidentes por animais peçonhentos: manual de rotinas. Belém: SESPA Secretaria de Estado de Saúde Pública do Pará, 2010.

Pardal et al. (2014) e Torrez (2016) constataram que na região Oeste do Pará existe um peculiar acidente escorpiônico que cursa com manifestações clínicas neurológicas, até então não descritas na literatura científica, como ataxia cerebelar, disdiadococinesia, mioclonias, sensação de "choque elétrico", disartria, dislalia, dismetria e fasciculação. Este fato sugere que 
haja variação e diversidade na toxicidade do veneno do $T$. obscurus nas diferentes áreas da bacia amazônica brasileira.

Diante dessa peculiaridade clínica no estado do Pará, Pardal e Gadelha (2010) propuseram intervenção com o soro antiescorpiônico (SAESC) ou o soro antiaracnídico (SAAR) de acordo com a classificação do acidente e dos sintomas peculiares da região (Figura 04).

Além dos tratamentos sintomáticos e específicos, deve-se salientar a importância do suporte às condições vitais da vítima, monitorando de maneira contínua e específica o sistema respiratório, pressão arterial, oxigenação, equilíbrio ácido básico e hidratação para o sucesso do tratamento (RECKZIEGEL, 2013).

Neste contexto, a enfermagem tem papel essencial para o manejo clínico e prevenção, porém estudos realizados por enfermeiros são raríssimos. Foram encontrados dois artigos de revisão publicados nos Estados Unidos em que os autores chamam atenção exatamente para a importância do reconhecimento do quadro clínico, realizar educação em saúde e reduzir ansiedade da família e do paciente (MCGHEE et al., 2015; SIMON, 2015).

Simon (2015) chama atenção dos enfermeiros norte-americanos, especialmente do Estado do Arizona, para o envenenamento causado pelo escorpião Centruroides sculpturatus/exilicauda, chamado popularmente de escorpião com casca, pois ele pode causar neurotoxicidade grave e potencialmente fatal em crianças menores de 5 anos, mais vulneráveis aos seus efeitos. Porém, as orientações aos enfermeiros acabam se restringindo aos cuidados focados na clínica e de suporte como administrar sintomáticos, benzodiazepínicos, antiveneno e monitorar padrão respiratório e cardíaco.

Foram realizados estudos por enfermeiros no município de Rurópolis, publicados em anais de Congressos e revistas científicas que revelam a existência de casos que evoluem com quadro neuromuscular e manifestações renais, em especial o quadro de insuficiência renal (CARDOSO et al., 2011; CARDOSO; GALVÃO; RODRIGUES, 2012; SANTANA et al., 2012; CARDOSO et al., 2015).

As vítimas do escorpionismo devem ser assistidas preferencialmente no âmbito hospitalar, onde serão tratadas conforme classificação clínica do caso, recebendo medicações sintomáticas, podendo ou não receber doses de soro antiescorpiônico. Sendo que, em casos graves, alguns necessitam de monitoramento intensivo, com auxílio de ventilação mecânica para manutenção da vida. Portanto, esses acidentes requerem investimentos para prevenção, controle e manejo adequados a esses casos (BRASIL, 2009). 
A quase totalidade dos estudos sobre acidente escorpiônico refere-se à descrição dos acidentes e à gravidade dos casos ocorridos em populações hospitalares altamente selecionadas. São escassos os estudos sobre as vulnerabilidades dos acidentados ao escorpionismo, de forma a revelar os componentes sociais e programáticos envolvidos no processo do acidente e envenenamento, ultrapassando apenas o componente individual, ressaltados em estudos epidemiológicos. O acidente escorpiônico é um fenômeno social que engloba questões políticas, econômicas, sociais, ambientais e de saúde. Por se tratar de um agravo negligenciado mundialmente, existe uma deficiência de políticas públicas, de alocação de recursos, de produção de imunoglobulinas, de incentivo às pesquisas e de produção de conhecimento para orientação de profissionais de saúde.

Em virtude da ocorrência desse envenenamento em particular, em alguns municípios do Estado do Pará, torna-se necessário conhecer os contextos de vulnerabilidade ao acidente por escorpião, mas também revelar sua epidemiologia e aspectos clínicos. Este conhecimento possibilitará melhor planejamento estratégico de ações de saúde no que diz respeito ao manejo clínico, na saúde ambiental, nas políticas públicas sociais e de educação que interfiram diretamente nos modos de produção e reprodução social e, consequentemente e não menos importante, nos indicadores de saúde. De tal maneira, a presente investigação aprofunda os estudos sobre a especificidade do escorpionismo no Pará, questionando como se caracteriza a clínica e a epidemiologia dos indivíduos acometidos e quais são os contex tos de vulnerabilidade presentes neste agravo. 


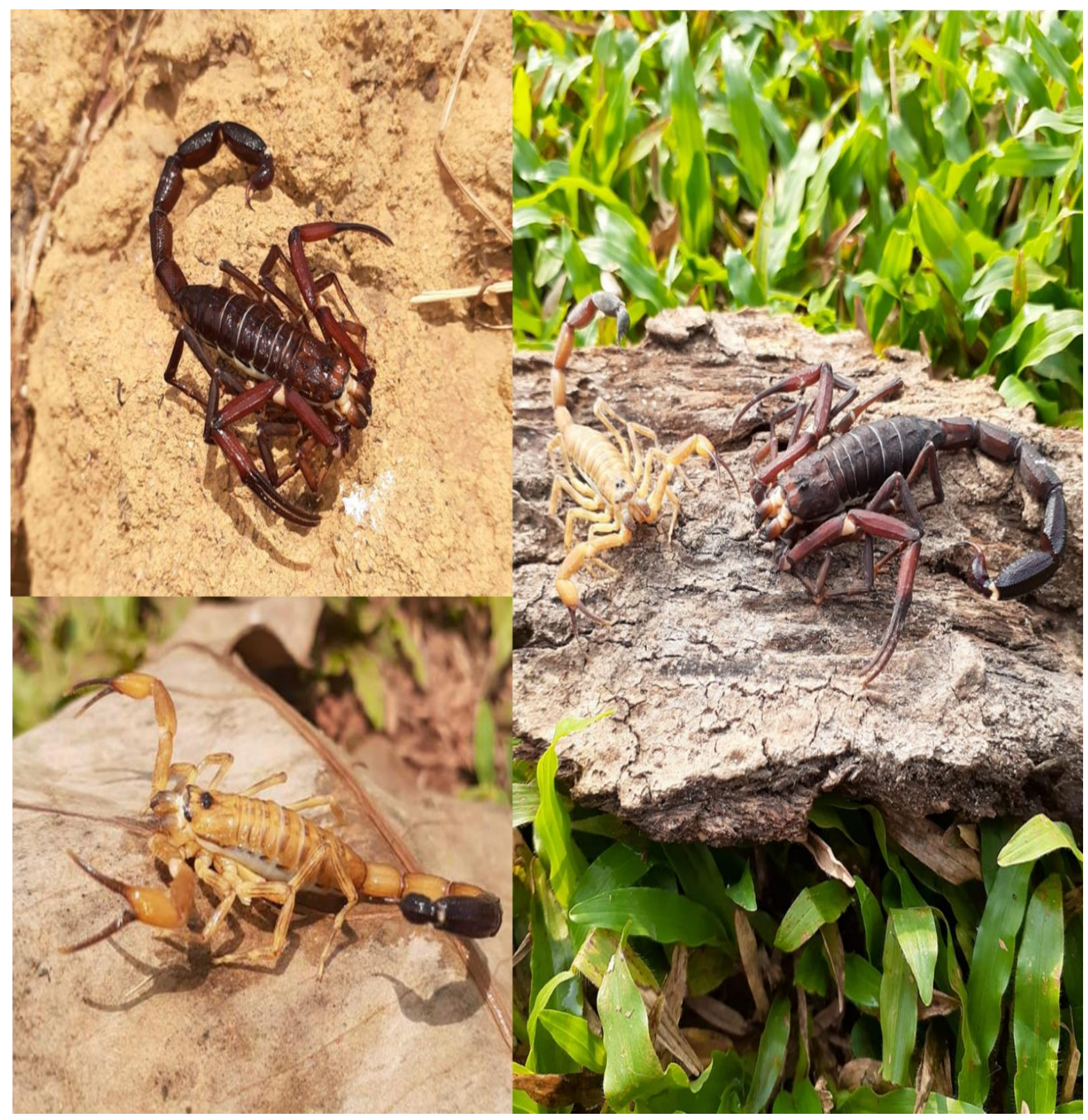




\section{OBJETIVOS}

\subsection{OBJETIVO GERAL:}

Analisar os aspectos epidemiológicos e clínicos dos acidentes escorpiônicos ocorridos no município de Rurópolis, Pará, propondo uma matriz de marcadores de vulnerabilidade.

\subsection{OBJETIVOS ESPECÍFICOS:}

1. Analisar aspectos epidemiológicos, clínicos e terapêuticos destes acidentes e;

2. Descrever elementos de vulnerabilidade individual e coletiva aos acidentes escorpiônicos. 


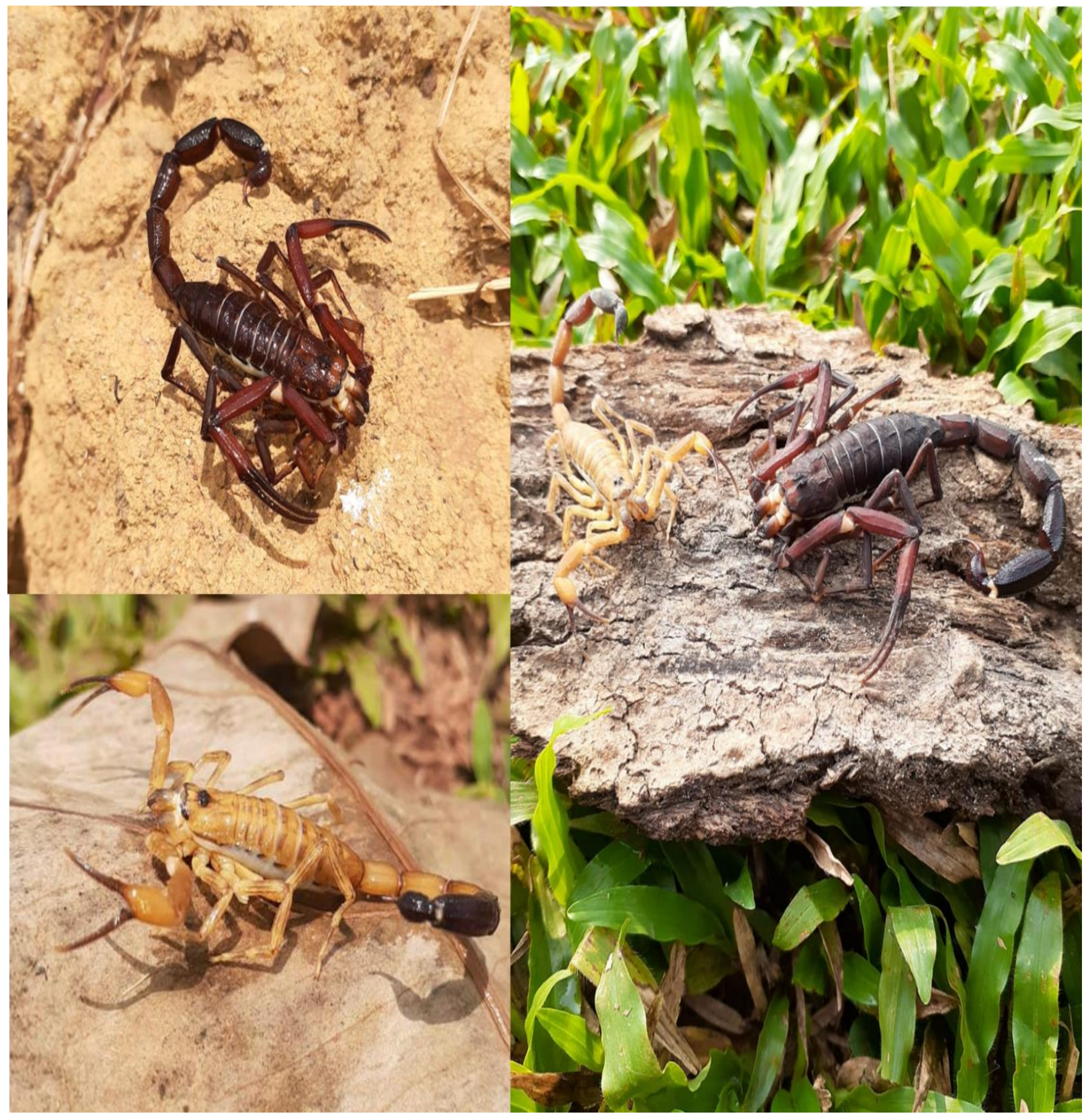




\section{MÉTODOS}

\subsection{Desenho do estudo}

O estudo é multimétodo, com abordagens quantitativa e qualitativa.

$\mathrm{Na}$ abordagem quantitativa foi feita uma pesquisa observacional, prospectiva e transversal, desenvolvida nas dependências do Hospital Municipal de Rurópolis, oeste do Estado do Pará, onde foram acompanhados os casos de escorpionismo ocorridos no período de outubro de 2016 a setembro de 2017, para caracterização clínica, epidemiológica e terapêutica.

$\mathrm{Na}$ abordagem qualitativa foram descritos e caracterizados marcadores das dimensões da vulnerabilidade, evidenciado nas entrevistas dos acidentados e no acompanhamento dos casos.

\subsection{Pressupostos teóricos e metodológicos}

Os resultados desta pesquisa com vítimas de acidente escorpiônico em Rurópolis, Pará foram analisados e organizados à luz da Teoria da Determinação Social do Processo Saúde e Doença, da Saúde Coletiva e da Epidemiologia Crítica, para então estruturar os marcadores de Vulnerabilidade ao agravo.

A Teoria da Determinação Social do Processo Saúde e Doença questiona o paradigma dominante da doença como um fenômeno individual e biológico e ressalta que a saúde e a doença também dependem das condições econômicas (renda, emprego, organização da produção), ambientes de convivência, ambientes de trabalho, cultura e valores, que podem interferir positiva ou negativamente na saúde dos grupos populacionais. Neste contexto, na superestrutura econômico ideológica, a concepção de saúde, o valor que se atribui à vida, reconhecimento de cidadania e o enfrentamento com as diferenças de gênero, etnia e classe social podem conferir maior ou menor proteção à saúde (ROCHA; DAVID, 2015; CAMPOS, 2009).

Trata-se uma teoria interpretativa que discute a abrangência da coletividade e do caráter histórico-social do processo saúde-doença. Estabelece uma relação entre o processo saúdedoença do coletivo e do indivíduo, uma vez que o primeiro determina as condições sobre as quais a variação biológica do segundo se assentará (ROCHA; DAVID, 2015). 
A determinação social da saúde é um processo multidimensional e coletivo. Neste, o sistema de acumulação econômico determina os modos de vida coletivos em distintas populações, as possibilidades de qualidade de vida, a saúde de distintas coletividades e de seus indivíduos (BREILH; MUÑOZ, 2009).

Neste contexto, a epidemiologia clássica e a causalidade não atendem às necessidades da determinação social da saúde e nem da saúde coletiva. Eis que a Epidemiologia Crítica vem para superar a noção restrita que a epidemiologia clássica tem, sem dispensá-la, mas articulando-se com ela (BREILH, 2010).

A epidemiologia crítica se baseia na clareza da teoria da necessidade, nas concepções sobre direitos humanos, nas categorias e formas de interpretar a qualidade de vida e seus determinantes, em preceitos e mecanismos de segurança humana e ética nas ações preventivas em prol da saúde (BREILH, 2006).

Sua construção exige uma bioética que extrapole as premissas clássicas (bem-estar, segurança genética, segurança ecológica e proteção às práticas e agentes nocivos) e que penetre nos direitos e na eticidade dos processos sociais e coletivos. A ética do modo de vida, como é chamada por Breilh, prima por formas humanas de trabalho, de direitos, equidade de gênero e de etnia, enfim, tudo que possibilite uma saúde coletiva como parte de um projeto emancipador da sociedade (BREILH, 2006)

Ela também propõe a construção inovadora do espaço da saúde, retomando a teoria crítica do espaço e da geografia, repensando a relação urbano-rural a partir da perspectiva da determinação social da saúde. Nessa lógica, a aceleração de processos históricos com perda de sustentabilidade, profundas inequidades urbanas, assim como o papel da nova ruralidade capitalista, estimulam a redução de espaços de vida nas cidades (BREILH, 2010).

A saúde tem caráter multidimensional, que se expressa em objeto, conceito e campo de ações de saúde que se transformam continuamente. O modo de vida de um grupo social não retrata unicamente sua história, mas também a história mais ampla de uma sociedade e, por sua vez, o modo de vida não só se expressa nos estilos de vida das pessoas e em seu cotidiano, como também se expressa nos processos que ocorrem nos organismos destas. Essa determinação não tem sentido único, como todo movimento dialético, porém os fenômenos mais específicos expressam-se nas instâncias mais gerais (BREILH, 2006). Portanto, a vulnerabilidade se refere às pessoas e não ao agravo ou doença.

Para atender a complexidade do fenômeno saúde, a epidemiologia crítica se apresenta em 3 dimensões: estrutural, particular e singular. A dimensão estrutural trata da lógica social e princípios de reprodução. A dimensão particular consiste nos modos e estilos de vida dos grupos 
sociais. A dimensão singular expressa os processos geno-fenotípicos e fisiológicos (BREILH, 2006).

Entre a dimensão geral e a particular existe uma relação hierárquica e uma forma de conexão que é a subsunção e a autonomia relativa, que são movimentos simultâneos e opostos, uma vez que entre o "macro e o micro existem determinantes do geral ante o particular, ao mesmo tempo que existe uma relativa autonomia e capacidade de incidência do particular ante o geral" (BREILH, 2006, p. 92-93).

Na terceira fase do processo de construção da epidemiologia crítica, no período de 1995 a 2002, além da proposta do neo humanismo popular e da busca da subjetividade, acentua-se a crítica sobre o risco e a exposição, como acepções reducionistas (BREILH, 2006). Nesse contexto, o conceito da Vulnerabilidade vem para superar essa ideia, sem anula-la.

O termo vulnerabilidade tem sido utilizado largamente em estudos científicos e algumas vezes, de forma equivocada. Ao longo dos tempos, vários teóricos conceituaram vulnerabilidade nas diversas áreas do conhecimento, mas foi na área de saúde, após a epidemia da AIDS na década de 80, a partir dos conceitos elaborados por Delor e Hubert, Mann e colaboradores e Paris, que Ayres e colaboradores estruturam o conceito de vulnerabilidade no Brasil.

O contexto da vulnerabilidade tem uma relação direta com a suscetibilidade, em que indivíduos e comunidades estão susceptíveis a um adoecimento ou agravo e, de modo inseparável, menor disponibilidade de recursos para sua proteção. Também pode-se dizer que consiste em uma chance de exposição das pessoas ao adoecimento, como resultante de um conjunto de aspectos que podem ser individuais e coletivos, uma vez que estes não são dissociáveis (AYRES et al., 1999; AYRES et al., 2006; SÁNCHEZ; BERTOLOZZI, 2007).

Uma pesquisa para construção de marcadores de vulnerabilidade à infecção, morte e adoecimento pelo HIV/AIDS por Takahashi (2006) abriu portas para diversos outros estudos para construção de instrumentos para avaliação de vulnerabilidade a diversos agravos. Neste sentido, Nichiata et al (2011) afirmam que o marcador de vulnerabilidade consiste em um elemento qualificador que, estando presente ou ausente, define e caracteriza a dimensão da vulnerabilidade.

As dimensões da vulnerabilidade estão estruturadas em três planos que interagem entre si: vulnerabilidade individual, vulnerabilidade social e vulnerabilidade programática (AYRES et al., 1999; AYRES et al., 2006; SÁNCHEZ; BERTOLOZZI, 2007).

A Vulnerabilidade Individual (dimensão cognitiva e comportamento pessoal) está relacionada ao grau e à qualidade da informação (saberes) que as pessoas possuem acerca dos 
problemas de saúde, sua elaboração e aplicação no cotidiano (práticas). Está diretamente ligada aos comportamentos que colaboram ou protegem a um determinado agravo ou adoecimento (AYRES et al., 1999; SÁNCHEZ; BERTOLOZZI, 2007).

Essa dimensão da vulnerabilidade depende diretamente do acesso ao conhecimento (informação) para então elabora-lo, incorpora-lo e transforma-lo em práticas protetivas, tornando-se assim uma potencialidade do sujeito. No caso do escorpionismo, é importante conhecer os hábitos e habitats do escorpião para transformar esse conhecimento em atitudes positivas como manter quintais limpos, usar equipamentos de proteção individual (EPI), checar calçados e roupas antes de vesti-los (TORREZ, 2016).

Torrez (2016) elencou como contextos que conferem vulnerabilidade individual ao escorpionismo no município de Santarém: baixa escolaridade, falta de qualificação profissional, trabalho informal, falta de acesso ao saneamento básico, coleta de lixo irregular, escassa participação em grupo comunitário, falta de proteção no trabalho e no lazer, estar em hábitat natural do animal, não fazer uso de EPI, tentar matar o animal após o acidente, falta de acesso ao serviço médico, falta de soro específico nas unidades de saúde próximas aos locais de acidente e nas unidades de referência, longo tempo de espera para o atendimento, dificuldade de acesso e acessibilidade ao serviço de referência e desconhecimento sobre a finalidade do antiveneno. Como reflexo desses fatores, observa-se a adoção de práticas inadequadas no cuidado ao acidentado como o uso de substâncias no local e fazer torniquete.

A Vulnerabilidade Social (dimensão coletiva) avalia as condições dos sujeitos que os impõem à maior ou menor poder de obtenção das informações, de acesso aos meios de comunicação, recursos cognitivos e bens materiais, bem como o poder de participar ou não de decisões políticas e em instituições. Está diretamente ligada ao acesso aos bens e serviços assegurados na constituição cidadã de 1988, como saúde, educação, trabalho e recursos materiais (MANN; TARANTOLA; NETTER, 1993; AYRES et al., 1999; SÁNCHEZ; BERTOLOZZI, 2007).

O acidente escorpiônico se configura em um problema de várias dimensões, em que se evidenciam claras vulnerabilidades. Este ultrapassa a questão meramente biológica, ao se tratar de agravo negligenciado que tem componentes ambientais, sociais, biológicos e econômicos envolvidos.

Retomando a questão do escorpionismo, a baixa escolaridade, a falta de qualificação profissional, a falta de acesso a saneamento básico, água potável e coleta irregular de lixo, falta de proteção no trabalho e lazer, morar ou estar em locais próximos ao hábitat do escorpião e 
usar substâncias no local ou usar torniquete, foram potenciais marcadores de vulnerabilidade social identificados na pesquisa de Torrez (2016).

Para mensurar as dimensões da vulnerabilidade social faz-se necessário conhecer a situação de vida das coletividades e não apenas do indivíduo, pois essas duas faces (indivíduo e coletividade) são indissociáveis e interdependentes (SÁNCHEZ; BERTOLOZZI, 2007).

Neste sentido, a questão do escorpionismo não se configura apenas como um problema de saúde pública, mas também ambiental e social, pois no Brasil e no mundo, este se tornou um evento urbano, devido desmatamento crescente e a ocupação humana desenfreada em hábitats antes silvestres. Esta invasão causa uma quebra na cadeia alimentar e destrói os abrigos do escorpião e, com isso, passa a procurar alimento e abrigo em residências, terrenos baldios e áreas de construção, aumentando o número de acidentes na zona urbana, principalmente em áreas periféricas onde existam habitações precárias e acúmulo de lixo, favorecendo a proliferação de insetos (BRASIL, 2009).

É preocupante ver a Amazônia, celeiro da biodiversidade, como nova fronteira agrícola nacional e atual porta de escoamento da produção de grãos do centro-oeste brasileiro. Com o Programa de Aceleração do Crescimento do Governo Federal, esta região recebeu obras que põem em xeque a sustentabilidade, biodiversidade e sobrevivência de povos, faunas e floras, como as hidrelétricas de Belo Monte e Tapajós. Esses grandes empreendimentos têm estimulado a imigração desenfreada, em busca de melhores condições de vida e de produção social e, consequentemente, crescimento desordenado de cidades.

Percebe-se também como um problema social a partir do crescimento desordenado de áreas periféricas nas cidades, sem mínimas condições de saneamento e moradia, aliado a um processo contínuo e avançado de desmatamento, que expõe diversos animais silvestres ao processo "urbanização". Interessa ressaltar que, diferentemente de estatísticas nacionais, o acidente escorpiônico na Amazônia ainda é predominantemente rural, apesar de se verificar o aumento de acidentes em áreas periurbanas e urbanas (CARDOSO et al., 2015; TORREZ, 2016).

A Vulnerabilidade Programática (dimensão coletiva) consiste na avaliação dos programas de controle de agravos a saúde, além do grau e qualidade de compromissos e esforços programáticos de cidades, estados e países acerca do gerenciamento, de recursos e do monitoramento dos programas nos diferentes níveis de atenção (AYRES et al., 1999).

Por meio da análise da dimensão programática da vulnerabilidade, percebe-se quantitativamente e qualitativamente o grau de comprometimento de um governo com o direito à saúde. Os territórios desses serviços de saúde devem ser interpretados e avaliados a partir das 
relações dinâmicas entre os contextos sociais e o processo saúde doença ocorridas em sua área de abrangência (organização, o vínculo e relação interpessoal entre usuários e profissionais, as ações preventivas, o controle do agravo e os recursos sociais existentes). O plano programático da vulnerabilidade é uma espécie de elo entre os planos individual e social (AYRES et al., 1999).

Percebe-se este fato ao se analisar novamente os potenciais marcadores de vulnerabilidade elencados por Torrez (2016) em relação aos acidentes escorpiônicos em Santarém, Pará, pois estes parecem compor ao mesmo tempo as três dimensões, parecendo-nos uma repetição. A pesquisadora elencou como marcadores: demora no atendimento dentro do hospital, falta de estrutura para atendimento do paciente (leito), o cuidado pré-hospitalar com aplicação de substâncias no local ou torniquete, falta de acesso ao serviço médico próximo ao local onde há maior número de acidentes, falta de soro específico nas unidades de saúde próximas aos locais de acidente e nas unidades de referência, dificuldade de acesso e acessibilidade ao serviço de referência e desconhecimento sobre a finalidade do antiveneno.

O acidente escorpiônico é um agravo negligenciado em escala mundial. No Brasil, apesar de ser um agravo de notificação compulsória, não se observam políticas públicas específicas e mais abrangentes, alocação de recursos para produção de antiveneno em quantidade suficiente para distribuição equânime às diversas regiões.

Apesar de todas as evidências científicas, publicadas em revistas internacionais renomadas, que comprovam a peculiaridade e a gravidade dos casos na região, o Ministério da Saúde ainda não atualizou as diretrizes assistenciais para o manejo clínico desses casos, estando em vigência o manual de acidentes por animais peçonhentos publicado há 16 anos. Esta defasagem representa uma fragilidade dos programas de vigilância epidemiológica no controle desse acidente em particular (BRASIL, 2001; TORREZ et al., 2015).

Também é importante ressaltar que os aspectos pós-acidentais estão intimamente relacionados ao acesso e acessibilidade ao sistema público de saúde. Portanto, o envenenamento escorpiônico se configura em grande desafio ao Sistema Único de Saúde (SUS) e à saúde pública, pois o aumento das taxas de morbidade e mortalidade requerem planejamento estratégico para o enfrentamento do problema bem como recursos financeiros para a produção de antivenenos específicos, internação hospitalar e, sobretudo, para ações preventivas e de controle dos acidentes. Este desafio torna-se ainda maior quando se trata do contexto amazônico, onde o princípio universal do SUS esbarra nas dimensões continentais da região e na má gestão dos recursos públicos. 
Caracterizar o escorpionismo, em suas interfaces clínica e epidemiológica, permitirá o desvelamento de necessidades que possam nortear adoção de medidas e ações em saúde mais eficazes no campo do cuidar da vítima, mas também no campo da promoção, proteção e prevenção em saúde. Revelar fragilidades, potencialidades e vulnerabilidades das pessoas que foram picadas por escorpião, além do fenômeno biológico, pode indicar caminhos para a superação desse problema público de saúde.

Compreende-se, portanto, que o conceito de vulnerabilidade amplia o alcance da compreensão dos fenômenos da saúde, no caso o escorpionismo, estando este no entrecruzamento de comportamentos, saberes, práticas, vivências individuais, subjetivas, condições sociais, políticas e culturais, juntamente com as ações preventivas em saúde e de controle de agravos. Este conceito não aniquila o conceito de risco, mas o engloba e amplia a perspectiva estatística e unicausal para uma perspectiva coletiva e de determinação social do processo saúde e doença (NICHIATA et al., 2008; SÁNCHEZ; BERTOLOZZI, 2007).

\subsection{Cenário do estudo}

A pesquisa foi realizada no município de Rurópolis, oeste do Estado do Pará, que está localizado a $1.170 \mathrm{~km}$ da capital, Belém, via rodoviária.

Localizada ao Oeste Paraense, na mesorregião do Tapajós, é um dos municípios que compõe a Floresta Nacional do Tapajós - FLONA Tapajós, possuindo área territorial de $7.021,321 \mathrm{~km}^{2}$ (figura 05). Sua população é estimada em 50.510 habitantes e está distribuída, majoritariamente, na zona rural e cuja economia é baseada na agricultura e na pecuária, com clima quente e úmido, com uma temperatura média anual que varia entre $22^{\circ} \mathrm{C}$ e $34^{\circ} \mathrm{C}$ (IBGE, 2019).

Figura 05 - a) Município de Rurópolis - Pará e b) Rodovias Transamazônica (BR 230) e Santarém-Cuiabá (BR 163). 


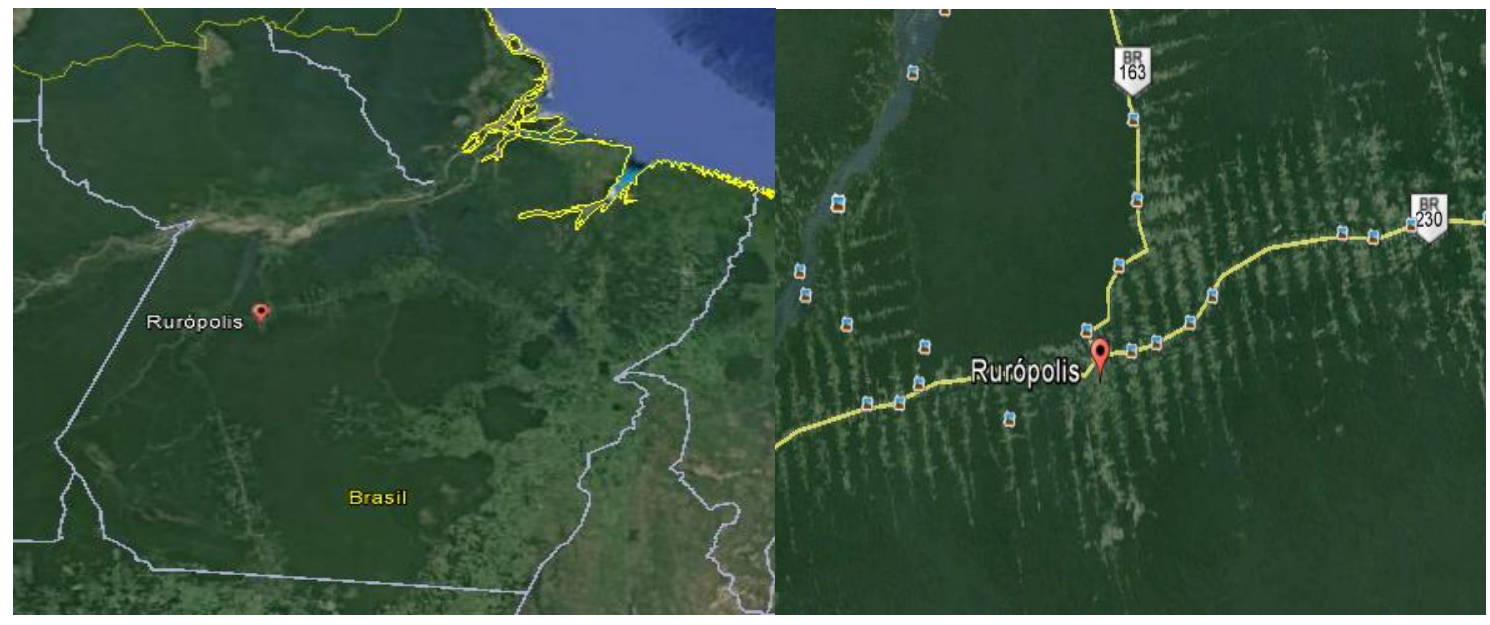

Fonte: Google Earth (2019)

O Município conta com uma rede de saúde composta por oito unidades básicas de saúde, sendo quatro na zona urbana e quatro na zona rural, um Centro de Atenção Psicossocial, uma Unidade Integrada de Atenção Primária e Vigilância em Saúde e um Hospital Municipal. A rede Suplementar de Saúde se limita a 02 clínicas com consultório médico, 04 com consultórios odontológicos e 01 laboratório de pequeno porte. Existe uma rede de atenção para referência de pacientes situado na Cidade de Santarém, a 217 Km de distância, acessível apenas por transporte rodoviário pois o transporte aéreo não é regularizado, onde os usuários contam com atendimentos especializados e alta complexidade.

A escolha do local se deu a partir da necessidade de explorar a temática em uma das cidades da mesorregião do Tapajós, uma vez que não se conhece de maneira sistemática o perfil do escorpionismo na região.

Um estudo realizado, no período de 2009 a 2013, revelou que esses casos representaram $5,15 \%$ (442/8.576) do total notificado no Pará, onde (21\%) destes foram considerados acidentes de trabalho. Com relação à classificação, $(57,23 \%)$ dos casos foram diagnosticados como leves, $(29,18 \%)$ foram moderados e $(3,62 \%)$ graves. Dos acidentados, $(93,9 \%)$ evoluíram para a cura e, em $(52,94 \%)$ deles não foi administrada antiveneno específica. Estes dados evidenciam a representatividade do acidente escorpiônico como agravo a saúde importante no município (CARDOSO et al., 2015).

Na ocorrência do acidente, mesmo os casos leves, são internados para acompanhamento clínico no Hospital Municipal de Rurópolis (HMR). Trata-se de hospital de média complexidade que atende a população não só do município, como de toda a microrregião, que corresponde a 6 municípios e também atende os que viajam pelas rodovias Santarém Cuiabá e Transamazônica. Nele são desenvolvidas práticas de campo dos estudantes dos cursos técnicos 
e de graduação em enfermagem, farmácia, biomedicina, medicina de faculdades privadas e da Universidade do Estado do Pará. O hospital dispõe de 40 leitos distribuídos entre clínica médica, cirúrgica, obstétrica, pediátrica e serviço de emergência. O mesmo conta com suporte de laboratório, exames de eletrocardiografia, exames radiológicos e ultrassonográficos.

\subsection{Sujeitos da pesquisa e caracterização da amostra}

Tomando-se amostra por conveniência, os sujeitos do estudo foram as vítimas de acidente escorpiônico e seus acompanhantes ou representantes legais atendidos no Hospital Municipal de Rurópolis. Estes foram selecionados de acordo com os critérios de inclusão: vítimas do acidente escorpiônico, TODOS que foram atendidos no HMR no período de um ano, entre outubro de 2016 a setembro de 2017. Foram adotados como critérios de exclusão: aqueles indivíduos com déficits cognitivos e memória. No entanto, nenhum dos indivíduos se enquadrou nesse critério, portanto, não necessitou exclusão de nenhum paciente ou acompanhante.

\subsection{Fonte dos dados e instrumentos de coleta de dados}

As informações foram coletadas a partir de prontuários e observação dos indivíduos, conforme fases da coleta:

1. Coleta de dados da ficha protocolar: avaliação clínica do acidentado, realização de exames laboratoriais e, se possível, eletrocardiografia (Apêdice I).

2. $\quad$ Coleta de dados da ficha de notificação do SINAN (Anexo I);

3. Coleta de dados de prontuários: sobre a reavaliação clínica a cada dia de internação até a alta hospitalar.

\subsection{Procedimentos na coleta de dados}

A coleta de dados foi realizada em tempo real, ou seja, o paciente foi acompanhado durante toda sua internação, no entanto, sem o pesquisador interferir nas condutas adotadas pelos profissionais de saúde. Toda pessoa vítima de escorpionismo foi assistida conforme o protocolo de pesquisa (Apêndice I).

A pesquisa contou com a participação de 04 pesquisadores na coleta dos dados: enfermeira Fernanda Cardoso, enfermeira Ana Beatriz Pedroso, enfermeira Yamilles Nascimento e Técnica de Enfermagem e acadêmica de Medicina Josivane Barbosa. 
Ao adentrar pelo setor de emergência do Hospital, os pesquisadores foram acionados pela equipe de plantão, independentemente do horário ou data da ocorrência. Portanto, o paciente, acompanhante ou representante legal, foi abordado após os procedimentos de admissão hospitalar, momento em que foi apresentada a pesquisa e o Termo de Consentimento Livre e Esclarecido (TCLE) ou o Termo de Assentimento (TA), o qual foi lido e assinado para que as etapas de coletas de dados fossem aplicadas, sejam elas: 1) Coleta de dados da ficha protocolar: avaliação clínica do acidentado, realização de exames laboratoriais e, quando possível, eletrocardiografia; 2) Coleta de dados da ficha de notificação do SINAN; 3) Coleta de dados de prontuários: sobre a reavaliação clínica a cada dia de internação até a alta hospitalar. A separação didática das etapas não impediu o acontecimento concomitante da coleta de dados, apesar de posteriormente serem necessárias outras revisitas aos dados.

No primeiro momento de coleta foram colhidas todas as informações acerca do acidente, seguindo os itens da ficha protocolar: I - Aspectos Socioeconômicos e Demográficos; II - Perfil de Saúde; III - Acidente Escorpiônico e IV - Assistência à Pessoa Vítima de Escorpionismo.

1. Em relação aos aspectos socioeconômicos e demográficos, foram levantados dados de identificação, data de nascimento, sexo, raça/cor, escolaridade, estado civil, crença religiosa, renda familiar (em salários mínimos), número de pessoas que habitam mesma residência, ocupação, endereço, ponto de referência, tipo de moradia, tipo de zona, número de cômodos, acesso a água encanada, rede de esgoto, coleta de lixo e destino do mesmo.

2. O perfil de saúde dos acidentados foi levantado a partir dos seguintes questionamentos: estatura, peso, Índice de Massa Corpórea -IMC, alergias, etilismo, tabagismo (quantos ao dia), antecedentes mórbidos pessoais, utiliza medicamentos (quais) e se já foi picado por escorpião (quando, qual a cor do animal e o que sentiu).

3. Para extração de dados acerca do acidente escorpiônico foram feitos questionamentos acerca da data do acidente, data da internação, horário do acidente, horário da internação, horário do início dos sintomas, local da picada, local de ocorrência do acidente, situação geradora do acidente, nome do animal, cor do animal, trouxe animal (identificação e espécie) e cuidados realizados antes da internação hospitalar. Porém, para extração dos dados clínicos foram necessários, além da entrevista, observação e avaliação clínica contínua e qualificados do acidentado para que se especificasse e constatasse a ocorrência de sinais e sintomas locais e sistêmicos, bem como a forma do surgimento, localização, evolução e duração dos mesmos. 
4. A assistência prestada ao paciente vítima do escorpionismo foi descrita a partir dos dados como sinais vitais (temperatura, pressão arterial, frequência cardíaca e frequência respiratória), escala de coma de glasglow, ausculta cardiopulmonar, exames gráficos (eletrocardiograma), exames laboratoriais (hemograma, creatinoquinase - CPK, fração miogoblina da creatinoquinase - CPK MB, transaminase oxalacética - TGO, transaminase pirúvica - TGP, uréia, creatinina, glicemia e urina I), acompanhamento clínico após 12, 24 e 48 horas após a primeira avaliação, classificação do caso, medicações utilizadas (anti-histamínico, corticoide, analgésico não esteroidal, anticonvulsivante, anestésico, hidratação venosa, antiveneno, outros), cuidados realizados, data e condições da alta hospitalar e observações.

O segundo momento ocorreu com coleta de dados da ficha de notificação de Acidentes por Animais Peçonhentos, preenchida na ocasião da internação hospitalar e atualizada após o desfecho do caso, para então ser transmitida ao SINAN. Esta ficha contém informações acerca de dados socioeconômicos, demográficos, circunstâncias geradoras do acidente, tipo de animal causador do acidente, local da picada, manifestações locais e sistêmicas, classificação do caso, antiveneno, evolução do caso e observações pertinentes.

O terceiro momento, coleta de dados de prontuários, foi necessário para confirmação e detalhamento dos dados colhidos na ficha protocolar acerca da reavaliação clínica a cada dia de internação até a alta hospitalar. Os dados gerados no prontuário são alimentados no Sistema de Informação de Informações Hospitalares - SIH, portanto geraram dados oficiais, juntamente com as informações da ficha de notificação.

\subsection{Análise dos Dados}

A análise dos resultados foi tratada a partir de diversas variáveis extraídas da ficha protocolar, da ficha de notificação e do prontuário que ao final foram traduzidas em grandes eixos de análise dos acidentes escorpiônicos: perfil socioeconômico e de saúde das vítimas, caracterizações epidemiológica, clínica e terapêutica do escorpionismo, bem como vulnerabilidades das vítimas ao acidente, conforme demonstrado no quadro 02 . 
Quadro 02 - Variáveis contidas na ficha protocolar aplicada às vítimas de acidente escorpiônico em Rurópolis, Pará.

\begin{tabular}{|c|c|}
\hline FONTE & ITENS GERAIS \\
\hline $\begin{array}{l}\text { Ficha } \\
\text { protocolar }\end{array}$ & $\begin{array}{l}\text { Aspectos } \\
\text { epidemiológicos, } \\
\text { Avaliação clínica do } \\
\text { acidentado, realização de } \\
\text { exames laboratoriais e, se } \\
\text { possível, } \\
\text { eletrocardiografia para } \\
\text { melhor descrição das } \\
\text { manifestações cardíacas } \\
\text { e musculares. }\end{array}$ \\
\hline
\end{tabular}

VARIÁVEIS

- Epidemiologia do Escorpionismo: Faixa etária, sexo, escolaridade, estado civil, crença/religião, renda per capita, ocupação, tipo de moradia, localização da moradia, água encanada, rede de esgoto e coleta de lixo (saneamento básico);

- Perfil de Saúde: IMC, alergias, etilismo, tabagismo, antecedentes mórbidos pessoais, faz uso de medicamentos, já foi picado por escorpião (quando, o que sentiu e qual a cor)

- Caracterização do Acidente Escorpiônico: acesso ao serviço de saúde (tempo para assistência), local da picada, local de ocorrência e circunstância geradora do acidente, captura do animal (identificação e cor), cuidados realizados antes da assistência em saúde;

- Caracterização Clínica do Escorpionismo: registro cronométrico de início, duração e forma de evolução dos sintomas.

- Assintomático

- Surgimento, evolução e duração de Manifestações locais (dor, edema, eritema, necrose, calor local, piloereção, sudorese, parestesia, sensação de choque elétrico e outros);

-Surgimento, evolução e duração Manifestações sistêmicas: neurológicas

(Ataxia de marcha, dismetria, disdiadococinesia, mioclonia, parestesia, disartria e sensação de choque elétrico); cardiorrespiratórias (taquicardia, bradicardia, hipertensão, hipotensão, taquipneia e bradipneia); Digestiva (náuseas, vômitos, disfagia); Oftalmológicas (visão turva, diplopia, nistagmo, anisocoria, midríase, miose, ptose palpebral, sensação de areia nos olhos); Urinárias (colúria, anúria, retenção urinária).

- Assistência à Pessoa Vítima de Escorpionismo: sinais vitais, Escala de Glasgow, ACP, glicemia, CPK, CPK-MB, TGO, TGP, hemograma, uréia, creatinina, Urina 1, ECG, avaliações com 12,24 e 48 horas após internação hospitalar, classificação de gravidade segundo o Ministério da Saúde, uso de medicamentos, antiveneno, alta hospitalar.

Elementos de Vulnerabilidade Individual

Elementos de Vulnerabilidade Programática

Elementos de Vulnerabilidade Social

Notificação Aspectos

do SINAN epidemiológicos e

clínicos da vítima do escorpionismo

Prontuário
Composta pelos grupos de dados: dados gerais, dados de residência,

antecedentes epidemiológicos, dados clínicos, dados do acidente, tratamento e conclusão do caso.

Vulnerabilidade Programática

Reavaliação clínica a - Caracterização do Acidente Escorpiônico: acesso ao serviço de cada dia de internação até a alta hospitalar

saúde (tempo para assistência), local da picada, local de ocorrência e circunstância geradora do acidente, cuidados realizados antes da assistência em saúde;

- Caracterização Clínica do Escorpionismo: registro de início, duração e forma de evolução dos sintomas.

- Assintomático

- Manifestações locais (dor, edema, eritema, necrose, calor local, piloereção, sudorese, parestesia, sensação de choque elétrico e outros);

- Manifestações sistêmicas: neurológicas

(Ataxia de marcha, dismetria, disdiadococinesia, mioclonia, parestesia, disartria e sensação de choque elétrico); cardiorrespiratórias (taquicardia, bradicardia, hipertensão, hipotensão, taquipneia e bradipneia); Digestiva (náuseas, vômitos, 
disfagia); Oftalmológicas (visão turva, diplopia, nistagmo, anisocoria, midríase, miose, ptose palpebral, sensação de areia nos olhos); Urinárias (colúria, anúria, retenção urinária).

- Assistência à Pessoa Vítima de Escorpionismo: sinais vitais, Escala de Glasgow, ACP, glicemia, CPK, CPK-MB, TGO, TGP, hemograma, uréia, creatinina, Urina 1, ECG, avaliações com 12, 24 e 48 horas após internação hospitalar, classificação de gravidade segundo o Ministério da Saúde, uso de medicamentos, antiveneno, alta hospitalar.

Elementos de Vulnerabilidade Individual

Elementos de Vulnerabilidade Programática

Para análise quantitativa os dados foram armazenados em planilhas no software Excel 2013, sendo tabulados e apresentados de forma descritiva, expostos em gráficos e tabelas para melhor visualização dos resultados.

Foi realizada análise descritiva com apoio estatístico, sendo as variáveis discretas descritas em frequências e percentuais e as variáveis numéricas por mediana e intervalo de confiança. A variáveis numéricas foram analisadas, quanto a normalidade, pelo teste de Kolmogorov-Smirnov.

Para avaliar a dimensão corporal em relação a classificação clínica e para avaliar o tempo de duração dos sintomas em relação ao uso do soro foi aplicado o teste de MannWhitney. Para relacionar o relacionar o tempo para o atendimento e a classificação do caso foi realizado o teste G. As análises estatísticas foram realizadas no bioestat 5.3. Nesses testes foi utilizado o nível de significância de $5 \%$.

A análise qualitativa foi realizada a partir de marcadores captados durante o preenchimento da ficha protocolar, que se desenvolveu de forma semiestruturada, para compor a vulnerabilidade individual e coletiva bem como dados secundários extraídos de fontes governamentais ou não. 


\subsection{Aspectos Éticos}

Com relação aos aspectos éticos da pesquisa, o estudo seguiu as recomendações da Resolução 466/12 do Conselho Nacional de Saúde (CNS), respeitando as normas e diretrizes para realização de pesquisa envolvendo seres humanos, adotando no seu âmbito as recomendações: autonomia, beneficência, não maleficência, justiça e equidade.

Esta pesquisa envolveu a participação direta de seres humanos, através de entrevista semiestruturada, gravação de vídeos e fotos, além dos prontuários, portanto foi utilizado um TCLE (Apêndice III) que foi assinado pelos participantes acidentados que aceitaram contribuir com a pesquisa.

Para os participantes menores de idade foi elaborado um TCLE diferenciado (Apêndice IV) para que o responsável assinasse autorizando a participação do menor no estudo. Quando os acidentados eram crianças maiores de sete anos ou adolescentes menores de 18 anos, foi apresentado a eles o Termo de Assentimento (Apêndice V) evidenciando que o mesmo aceitou participar da pesquisa, contudo o termo de assentimento não eliminou a necessidade de fazer o termo de consentimento livre e esclarecido que foi assinado pelo responsável ou representante legal do menor.

Além disso, para não haver identificação dos pacientes foram adotados codinomes numéricos. Por se tratar de um estudo voltado aos prontuários, foi elaborado um Termo de Consentimento de Uso de Dados (TCUD) (Apêndice VI), direcionado ao responsável pelos prontuários autorizando o fornecimento dos dados dos mesmos aos pesquisadores.

O projeto foi aprovado pelo Comitê de Ética em Pesquisa (CEP) da Universidade do Estado do Pará, campus XII - Tapajós, sob o número de Protocolo CAEE 59234916.5.0000.5168, aprovado em 21 de setembro de 2016, parecer $\mathrm{n}^{\circ} 1.737 .875$ (Anexo III). 


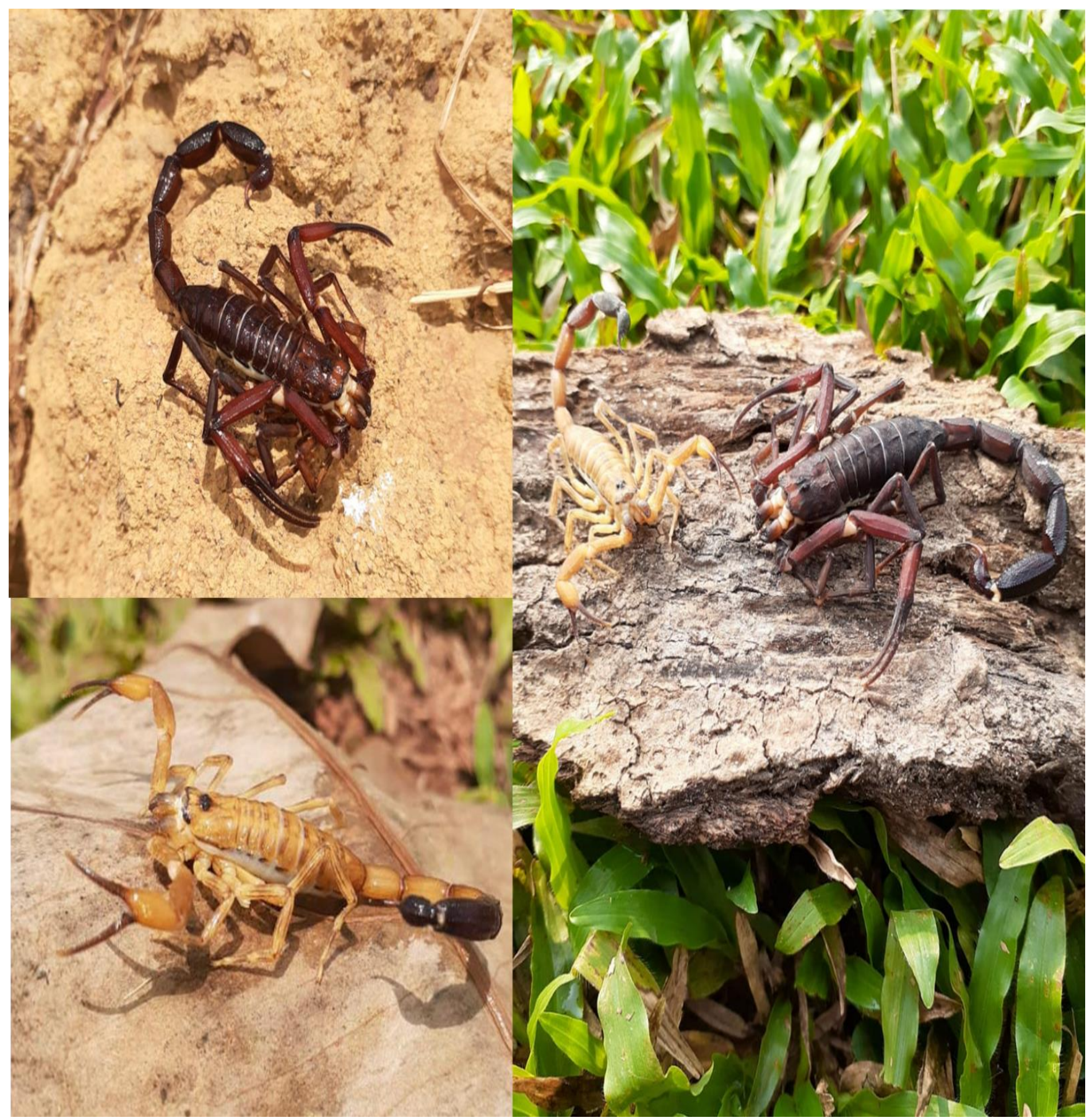




\section{RESULTADOS}

Os resultados desta pesquisa com vítimas de acidente escorpiônico em Rurópolis, Pará, foram apresentados em três eixos de análise: perfil socioeconômico e de saúde, caracterização epidemiológica, caracterização clínica e terapêutica.

\subsection{Perfil socioeconômico e de saúde das vítimas de escorpionismo}

O grupo social estudado é composto por 117 pessoas que sofreram acidente escorpiônico no período de outubro de 2016 a setembro de 2017, no hospital municipal de Rurópolis.

Tabela 01 - Perfil socioeconômico das vítimas de acidentes escorpiônicos, município de Rurópolis, PA, outubro de 2016 a setembro de 2017.

\begin{tabular}{|c|c|c|c|}
\hline Perfil sociodemográfico & Variável & $\mathrm{n}^{\circ} 117$ & $\%$ \\
\hline \multirow[t]{2}{*}{ Sexo } & Masculino & 88 & 75,20 \\
\hline & Feminino & 29 & 24,80 \\
\hline \multirow[t]{8}{*}{ Faixa etária (anos) } & $0-10$ & 10 & 08,54 \\
\hline & $11-20$ & 24 & 20,51 \\
\hline & $21-30$ & 19 & 16,23 \\
\hline & $31-40$ & 26 & 22,22 \\
\hline & $41-50$ & 14 & 12,00 \\
\hline & $51-60$ & 15 & 12,82 \\
\hline & $61-70$ & 06 & 05,12 \\
\hline & $71-80$ & 03 & 02,56 \\
\hline \multirow[t]{3}{*}{ Cor } & Pardo & 69 & 58,97 \\
\hline & Negro & 30 & 25,65 \\
\hline & Branco & 18 & 15,38 \\
\hline \multirow[t]{5}{*}{ Estado civil } & União/Estável & 13 & 11,13 \\
\hline & Solteiro & 56 & 47,86 \\
\hline & Casado & 45 & 38,46 \\
\hline & Divorciado & 01 & 00,85 \\
\hline & Viúvo & 02 & 01,70 \\
\hline \multirow[t]{9}{*}{ Ocupação } & Agricultor & 58 & 49,57 \\
\hline & Do lar/doméstica & 04 & 03,42 \\
\hline & Estudante & 27 & 23,07 \\
\hline & Autonômo/empresário & 07 & 06,00 \\
\hline & Menor fora da escola & 06 & 05,14 \\
\hline & Aposentado & 02 & 01,70 \\
\hline & Funcionário Público & 03 & 02,56 \\
\hline & $\begin{array}{l}\text { Mecânico/Serrador/Pedreiro/ma } \\
\text { deireiro }\end{array}$ & 09 & 07,69 \\
\hline & Sem ocupação & 01 & 00,85 \\
\hline Renda Familiar & $0-1$ & 12 & 10,25 \\
\hline (salário mínimo de 2017 - R\$ & $1-2$ & 17 & 14,55 \\
\hline \multirow{3}{*}{$937,00)$} & $2-3$ & 75 & 64,10 \\
\hline & $>3$ & 02 & 01,70 \\
\hline & Não Informado & 11 & 09,40 \\
\hline \multirow[t]{7}{*}{ Escolaridade } & Fundamental incompleto & 80 & 68,37 \\
\hline & Fundamental completo & 06 & 05,12 \\
\hline & Médio incompleto & 14 & 12,00 \\
\hline & Médio completo & 06 & 05,12 \\
\hline & Superior incompleto & 0 & 0 \\
\hline & Superior completo & 01 & 00,85 \\
\hline & Não alfabetizado & 10 & 08,54 \\
\hline
\end{tabular}




\begin{tabular}{|c|c|c|c|}
\hline \multirow[t]{5}{*}{ Crença Religiosa } & Católica & 54 & 46,15 \\
\hline & Evangélico & 25 & 21,36 \\
\hline & Adventista & 07 & 06,00 \\
\hline & Sem religião & 10 & 08,54 \\
\hline & Não Informado & 21 & 17,95 \\
\hline \multirow[t]{3}{*}{ Tipos de Moradia } & Madeira & 89 & 76,10 \\
\hline & Alvenaria & 26 & 22,20 \\
\hline & Mista & 02 & 01,70 \\
\hline \multirow[t]{7}{*}{$\mathrm{N}^{\mathrm{o}}$ Cômodos } & 01-02 & 05 & 04,27 \\
\hline & 03 & 07 & 06,00 \\
\hline & 04 & 47 & 40,17 \\
\hline & 05 & 18 & 15,38 \\
\hline & 06 & 09 & 07,69 \\
\hline & $>06$ & 03 & 02,56 \\
\hline & Não informado & 28 & 23,93 \\
\hline \multirow[t]{6}{*}{$\mathrm{N}^{\circ}$ de moradores } & $01-02$ & 08 & 06,85 \\
\hline & 03-04 & 44 & 37,60 \\
\hline & $05-06$ & 45 & 38,47 \\
\hline & 07-08 & 10 & 08,54 \\
\hline & $09-10$ & 05 & 04,27 \\
\hline & Não Informado & 05 & 04,27 \\
\hline \multirow[t]{2}{*}{ Local da moradia } & Urbana & 38 & 32,48 \\
\hline & Rural & 79 & 67,52 \\
\hline \multirow[t]{3}{*}{ Coleta de resíduos } & Sim & 41 & 35,05 \\
\hline & Não & 74 & 63,25 \\
\hline & Não Informado & 02 & 01,70 \\
\hline \multirow{4}{*}{$\begin{array}{l}\text { Destino dos resíduos } \quad \text { (sem } \\
\text { coleta) }\end{array}$} & Queima & 59 & 79,73 \\
\hline & Céu aberto & 12 & 16,22 \\
\hline & Fossa aberta & 01 & 01,35 \\
\hline & Não Informado & 02 & 02,70 \\
\hline \multirow[t]{3}{*}{ Água encanada } & $\operatorname{Sim}$ & 85 & 72,65 \\
\hline & Não & 17 & 14,53 \\
\hline & Não Informado & 15 & 12,82 \\
\hline \multirow[t]{2}{*}{ Rede de esgoto público } & Sim & 0 & 0 \\
\hline & Não & 117 & 100 \\
\hline
\end{tabular}

O acidente atingiu o sexo masculino $(75,2 \%)$, principalmente nas faixas etárias entre os 31 a 40 anos de idade $(22,22 \%)$ e 11 a 20 anos $(20,51 \%)$ e 21 a 30 anos (16,23\%). Ressalta-se que primeira e a terceira faixas etárias $(38,45 \%)$ representam a população economicamente ativa.

Em relação à raça ou cor, $(58,97 \%)$ declaram-se pardos e $(25,65 \%)$ negros. A maioria é solteiro $(47,86 \%)$, católico $(46,15 \%)$, agricultor $(49,57 \%)$, que conseguiram concluir o ensino fundamental $(68,37 \%)$ e que, portanto, possui renda familiar entre 2 a 3 salários mínimos $(64,10 \%)$ e que é compartilhada com mais 03 a 06 pessoas $(76,07 \%)$.

Entre as vítimas, a maioria mora em casa construída em madeira (76,10\%), com 04 cômodos $(40,17 \%)$, localizados na zona rural $(67,52 \%)$, sem acesso a coleta de resíduos sólidos $(63,25 \%)$ e entre estes $(75,73 \%)$, por conseguinte, incineram o lixo domiciliar. Entretanto, $(72,65 \%)$ possuem água encanada em suas residências, porém sem o devido tratamento. $\mathrm{O}$ município de Rurópolis não possui rede de esgoto. 
Tabela 02 - Perfil de saúde das vítimas de acidentes escorpiônicos no município de Rurópolis- PA, outubro de 2016 a setembro de 2017.

\begin{tabular}{|c|c|c|c|}
\hline Perfil de saúde & Variável & $\mathrm{n}^{\circ} 117$ & $\%$ \\
\hline \multirow{7}{*}{ IMC } & Baixo peso & 10 & 08,54 \\
\hline & Adequado & 39 & 33,33 \\
\hline & Sobrepeso & 27 & 23,10 \\
\hline & Obesidade Grau I & 05 & 04,27 \\
\hline & Obesidade Grau II & 01 & 00,85 \\
\hline & Obesidade Grau III & 0 & 0 \\
\hline & Não informado & 35 & 29,91 \\
\hline \multirow[t]{3}{*}{ Etilismo } & Sim & 27 & 23,10 \\
\hline & Não & 80 & 68,36 \\
\hline & Não Informado & 10 & 08,54 \\
\hline \multirow[t]{3}{*}{ Tabagismo } & Sim & 15 & 12,82 \\
\hline & Não & 92 & 78,64 \\
\hline & Não informado & 10 & 08,54 \\
\hline \multirow[t]{3}{*}{ Alergias } & Sim & 12 & 10,25 \\
\hline & Não & 96 & 82,05 \\
\hline & Não Informado & 09 & 07,70 \\
\hline \multirow[t]{3}{*}{ Antecedentes mórbidos } & Sim & 24 & 20,51 \\
\hline & Não & 83 & 70,95 \\
\hline & Não Informado & 10 & 08.54 \\
\hline \multirow[t]{3}{*}{ Uso de medicamentos } & Sim & 18 & 15,40 \\
\hline & Não & 89 & 76,06 \\
\hline & Não Informado & 10 & 08,54 \\
\hline \multirow[t]{2}{*}{ Sabe o nome do medicamento } & Sim & 16 & 88,88 \\
\hline & Não & 02 & 11,12 \\
\hline \multirow[t]{2}{*}{ Sabe para que serve o medicamento } & Sim & 16 & 88,88 \\
\hline & Não & 02 & 11,12 \\
\hline \multirow{3}{*}{$\begin{array}{l}\text { História anterior de picada por } \\
\text { escorpião }\end{array}$} & Sim & 47 & 40,17 \\
\hline & Não & 64 & 54,70 \\
\hline & Não Informado & 06 & 05,13 \\
\hline \multirow{11}{*}{$\begin{array}{l}\text { Tempo em que ocorreu o acidente } \\
\text { anterior }\end{array}$} & $<1$ ano & 03 & 06,40 \\
\hline & $01-03$ anos & 15 & 31,91 \\
\hline & $04-06$ anos & 08 & 17,02 \\
\hline & $07-09$ anos & 04 & 08,51 \\
\hline & $10-12$ anos & 07 & 14,89 \\
\hline & $13-15$ anos & 03 & 06,38 \\
\hline & $16-18$ anos & 01 & 02,12 \\
\hline & $19-21$ anos & 03 & 06,40 \\
\hline & $22-24$ anos & 00 & 00,00 \\
\hline & $25-28$ anos & 01 & 02,12 \\
\hline & Não sabe informar & 02 & 04,25 \\
\hline \multirow[t]{4}{*}{ Cor do animal do acidente anterior } & Preto & 28 & 59,60 \\
\hline & Amarelo & 15 & 31,90 \\
\hline & Vermelho & 02 & 04,25 \\
\hline & Não viu & 02 & 04,25 \\
\hline \multirow[t]{3}{*}{ Quadro clínico do acidente anterior } & Assintomático & 17 & 36,17 \\
\hline & Sintomático & 27 & 57,45 \\
\hline & Não Informado & 03 & 06,38 \\
\hline \multirow{8}{*}{$\begin{array}{l}\text { Sintomas referidos do acidente } \\
\text { anterior }\end{array}$} & Dor & 11 & 40,75 \\
\hline & Dor e parestesia & 05 & 18,52 \\
\hline & Dor, parestesia e choque elétrico & 04 & 14,81 \\
\hline & Parestesia & 02 & 07,41 \\
\hline & Parestesia e "língua pesada" & 01 & 03,70 \\
\hline & Parestesia e choque elétrico & 01 & 03,70 \\
\hline & Choque elétrico & 02 & 07,41 \\
\hline & Choque elétrico e disartria & 01 & 03,70 \\
\hline
\end{tabular}


Para melhor compreensão das condições de saúde foi realizado levantamento do perfil de saúde prévio que permitiu afirmar que a maioria dos acidentados possuí peso adequado à sua estatura (33,33\%), que negam consumir álcool ou tabaco, $(68,36 \%)$ e $(78,64 \%)$, respectivamente. Estes ainda negam possuir alergias de qualquer natureza (82,05\%), conhecer antecedentes mórbidos $(70,95 \%)$ e utilizar medicamentos de forma contínua $(76,06 \%)$. Entre aqueles que afirmam fazer uso contínuo de medicamentos, mostram conhecer o nome do medicamento $(88,88 \%)$ e sua função $(88,88 \%)$.

A maioria dos acidentados $(54,70 \%)$ afirmou que este foi o primeiro acidente envolvendo escorpiões. Os demais acidentados, (44,30\%) já haviam sido vítimas de escorpionismo ocorridos há, no máximo, 03 anos (31,91\%), sendo identificado o escorpião preto como causador do acidente $(59,60 \%)$. A maioria destes afirmou ter apresentado sintomas $(57,45 \%)$, entre eles a dor foi o mais citado $(74,08 \%)$, seja isolada $(40,75 \%)$ ou associada a outros sintomas $(33,33 \%)$.

\subsection{Caracterização epidemiológica do acidente escorpiônico}

Os 117 acidentes escorpiônicos aconteceram o ano inteiro, não sendo observado sazonalidade. O mês menos incidente foi setembro com 02 casos $(1,75 \%)$ e os mais incidentes foram abril e maio, com 36 casos ao total (30,76\%) (Gráfico 01).

Gráfico 01 - Distribuição dos acidentes escorpiônicos, por mês de ocorrência, durante os meses de outubro de 2016 a setembro de 2017, Rurópolis, Pará.

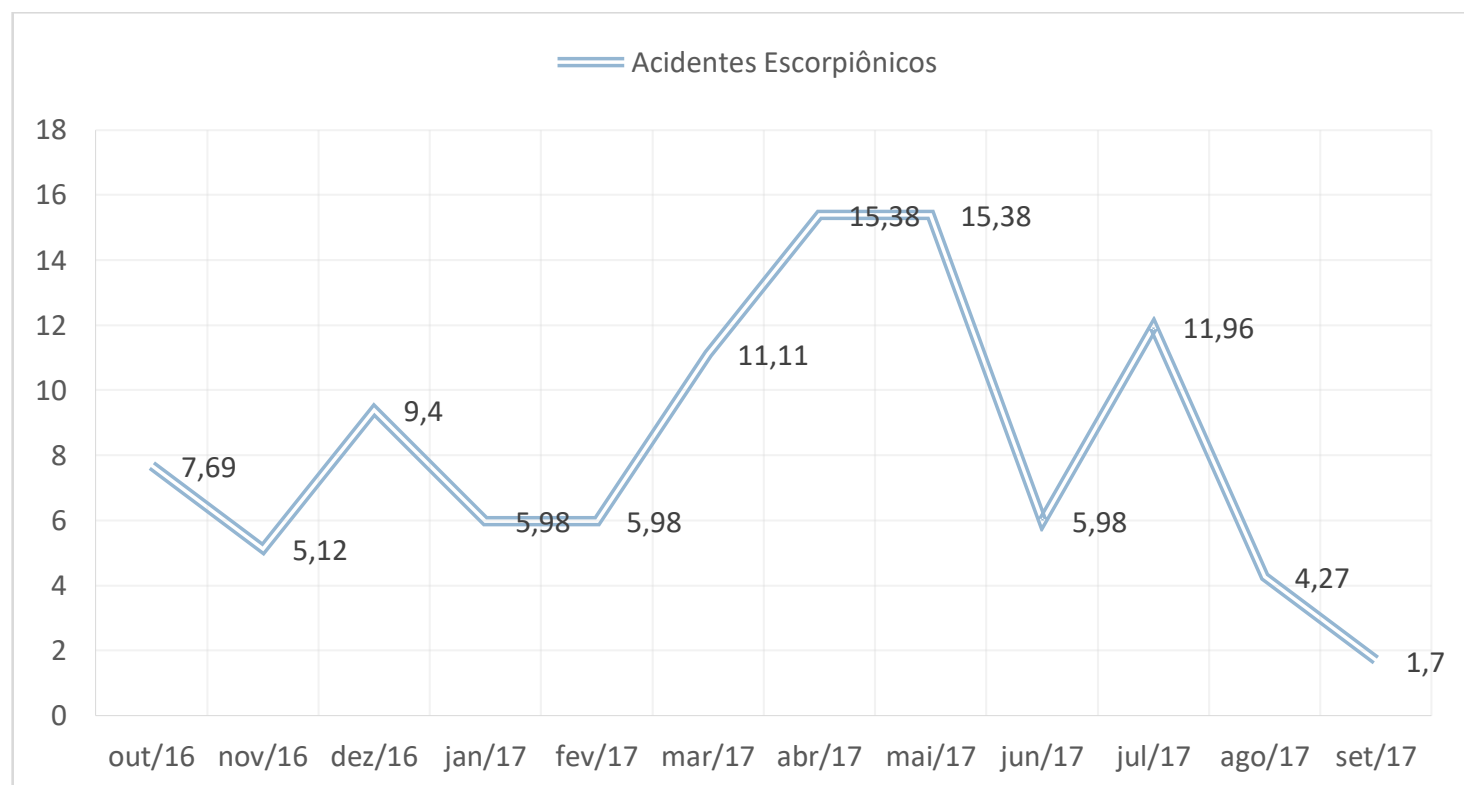


Analisando os meses de forma agrupada, o quarto trimestre de 2016 teve 26 casos (22,22\%), o primeiro trimestre de 2017 teve 27 casos (23,08\%), o segundo trimestre de 2017 teve 43 casos $(36,75 \%)$ e o terceiro trimestre de 2017 teve 21 casos $(17,95 \%)$, portanto, é possível afirmar que, nessa pesquisa, os meses de abril, maio e junho fazem parte do período mais prevalente seguidos do período menos prevalente com os meses julho, agosto e setembro.

Em relação aos aspectos epidemiológicos do acidente escorpiônico em Rurópolis, adotou-se as condições do acidente relacionados ao: o horário de ocorrência do acidente, tempo decorrido entre o acidente e o atendimento em estabelecimento de saúde, tempo decorrido entre o acidente e o início dos sintomas, local de inoculação do veneno, local de ocorrência do acidente, situação geradora do acidente, nome e cor do animal (se trouxe o animal para identificação) e se o mesmo realizou cuidados antes de chegar a unidade de saúde.

Tabela 03 - Distribuição das vítimas dos acidentes escorpiônicos, segundo as condições de ocorrência, no município de Rurópolis- PA, outubro de 2016 a setembro de 2017.

\begin{tabular}{|c|c|c|c|}
\hline Condições do acidente & Variável & $\mathrm{n}^{\circ} 117$ & $\%$ \\
\hline \multirow{5}{*}{ Horário de ocorrência do acidente } & $00-06 \mathrm{~h}$ & 08 & 06,84 \\
\hline & $06-12 \mathrm{~h}$ & 48 & 41,02 \\
\hline & $12-18 \mathrm{~h}$ & 40 & 34,20 \\
\hline & $18-24 \mathrm{~h}$ & 16 & 13,67 \\
\hline & Não informou & 05 & 04,27 \\
\hline Tempo decorrido entre o acidente e o atendimento de & $<\mathrm{ou}=1 \mathrm{~h}$ & 20 & 17,09 \\
\hline \multirow[t]{5}{*}{ Saúde } & $>1 \mathrm{~h}-3 \mathrm{~h}$ & 44 & 37,60 \\
\hline & $>3 h-6 h$ & 35 & 29,90 \\
\hline & $>6 h-12 h$ & 14 & 12,00 \\
\hline & $>12 \mathrm{~h}$ & 01 & 00,85 \\
\hline & Não Informado & 03 & 02,56 \\
\hline \multirow{5}{*}{$\begin{array}{l}\text { Tempo decorrido entre o acidente e o início dos } \\
\text { sintomas (n 116) }\end{array}$} & Imediato & 44 & 37.93 \\
\hline & Até $30 \mathrm{~min}$ & 38 & 32,75 \\
\hline & $>30 \min -01 \mathrm{~h}$ & 15 & 12,93 \\
\hline & $>01 \mathrm{~h}-03 \mathrm{~h}$ & 12 & 10,35 \\
\hline & $>03 \mathrm{~h}-06 \mathrm{~h}$ & 07 & 06,04 \\
\hline \multirow[t]{7}{*}{ Local de inoculação do veneno } & Dedo do Pé & 02 & 01,71 \\
\hline & Dedo da Mão & 19 & 16,25 \\
\hline & Pé & 18 & 15,38 \\
\hline & Mão & 18 & 15,38 \\
\hline & Perna/Coxa & 24 & 20,52 \\
\hline & Antebraço/Braço & 31 & 26,50 \\
\hline & Tronco & 05 & 04,26 \\
\hline \multirow[t]{6}{*}{ Local de ocorrência do acidente } & Área rural & 53 & 45,30 \\
\hline & Domicílio Rural & 34 & 29,06 \\
\hline & Domicílio Urbano & 24 & 20,52 \\
\hline & Peridomicílio Rural & 03 & 02,56 \\
\hline & Peridomicílio Urbano & 01 & 00,85 \\
\hline & Outros & 02 & 01,71 \\
\hline \multirow[t]{5}{*}{ Situação geradora do acidente } & Tarefas cotidianas & 42 & 35,90 \\
\hline & Trabalho & 59 & 50,42 \\
\hline & Lazer & 13 & 11,12 \\
\hline & Repouso & 01 & 00,85 \\
\hline & Sem informação & 02 & 01,71 \\
\hline
\end{tabular}




\begin{tabular}{llll}
\hline Nome do animal & Escorpião & 109 & 93,17 \\
& Não viu & 02 & 01,71 \\
& Não identificado & 03 & 02,56 \\
& Sem informação & 03 & 02,56 \\
\hline Cor do animal & Preto & 96 & 88,07 \\
& Amarelo & 11 & 10,09 \\
& Marrom & 02 & 01,84 \\
\hline Trouxe o animal & Sim & 06 & 05,12 \\
& Não & 111 & 94,88 \\
\hline Identificação do animal & Tityus obscurus & 05 & 83,33 \\
& Tityus strandi & 01 & 16,67 \\
\hline Realizou procedimentos antes do atendimento & Sim & 26,06 \\
hospitalar & Não & 70,94 \\
\hline Procedimentos realizados antes do atendimento & Ingestão de substâncias & 14 & 41,17 \\
hospitalar (n 34) & Aplicou substância no local 08 & 23,53 \\
& Ingestão de substâncias & 05 & 14,71 \\
& e aplicação de substâncias & \\
& no local & Ingestão de substâncias & 01 \\
& e aplicação de Torniquete & 02,94 \\
& Torniquete & 05 & 14,71 \\
& Lavagem com água e sabão01 & 02,94 \\
\hline
\end{tabular}

A maioria dos acidentados conseguiu chegar ao Hospital Municipal de Rurópolis em menos de 3 horas após a ocorrência do acidente $(54,69 \%)$ e apresentou sintomas em menos de 1 hora após a inoculação do veneno $(83,61 \%)$ sendo que, destes, $(37,93 \%)$ afirmou que os sintomas se manifestaram imediatamente.

Dos 117 acidentes ocorridos, $(93,18 \%)$ identificaram o animal envolvido no acidente como escorpião e, destes, $(88,07 \%)$ relataram que o animal era da cor preta, $(10,09 \%)$ amarela, $(01,84 \%)$ marrom. Apenas $(5,12 \%)$ dos 117 acidentados levou o animal ao serviço de saúde (Fotografias 02, 03, 04, 05 e 06) e (0,85\%) levou uma fotografia do animal causador do acidente, na qual é possível perceber que se trata de uma fêmea pois carregava filhotes em seu dorso (figura 11).

Figura 06 - Tityus Obscurus jovem causador de acidente $n^{\circ}$ 03, no Travessão da Perdida, BR 230 e BR 163, zona rural, Rurópolis, 2016. Legenda: a) face ventral; b) face dorsal

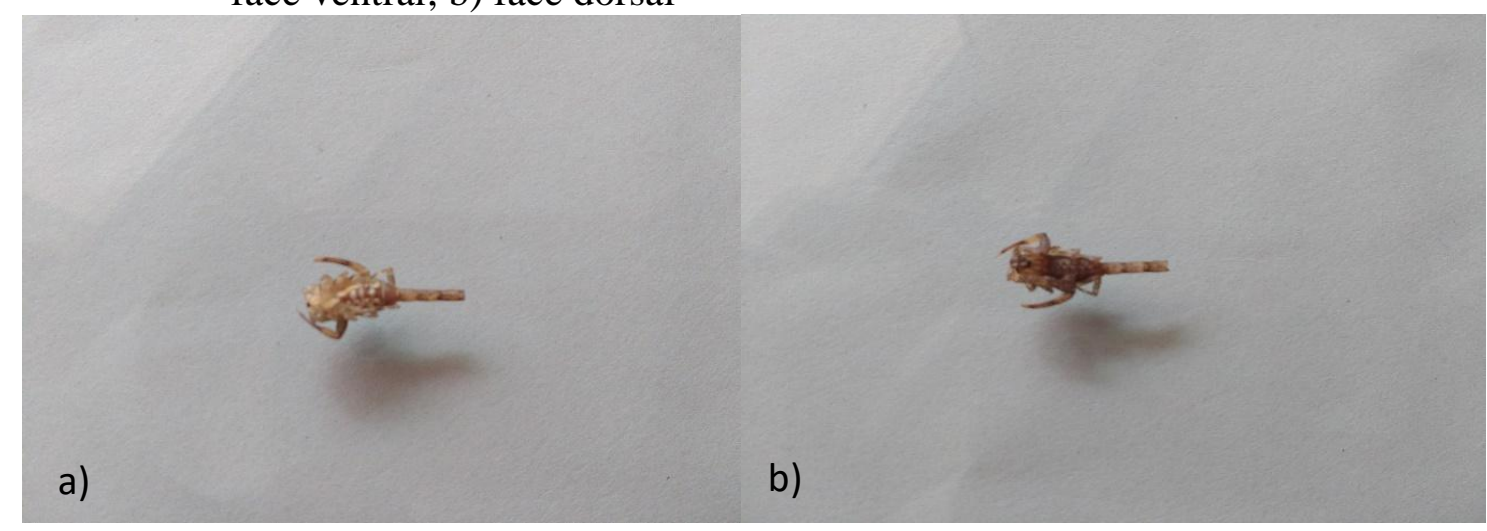

Fonte: Yamilles Nascimento (2016). Identificado por Bertani, R. Laboratório Especial de Ecologia e Evolução, Instituto Butantan, São Paulo, 2018. 
Figura 07 - Tityus strandi causador de acidente ${ }^{\circ} 36$, no Comunidade Peixotinho, Km 75, BR 230 e BR 163, zona rural, Rurópolis, 2017.

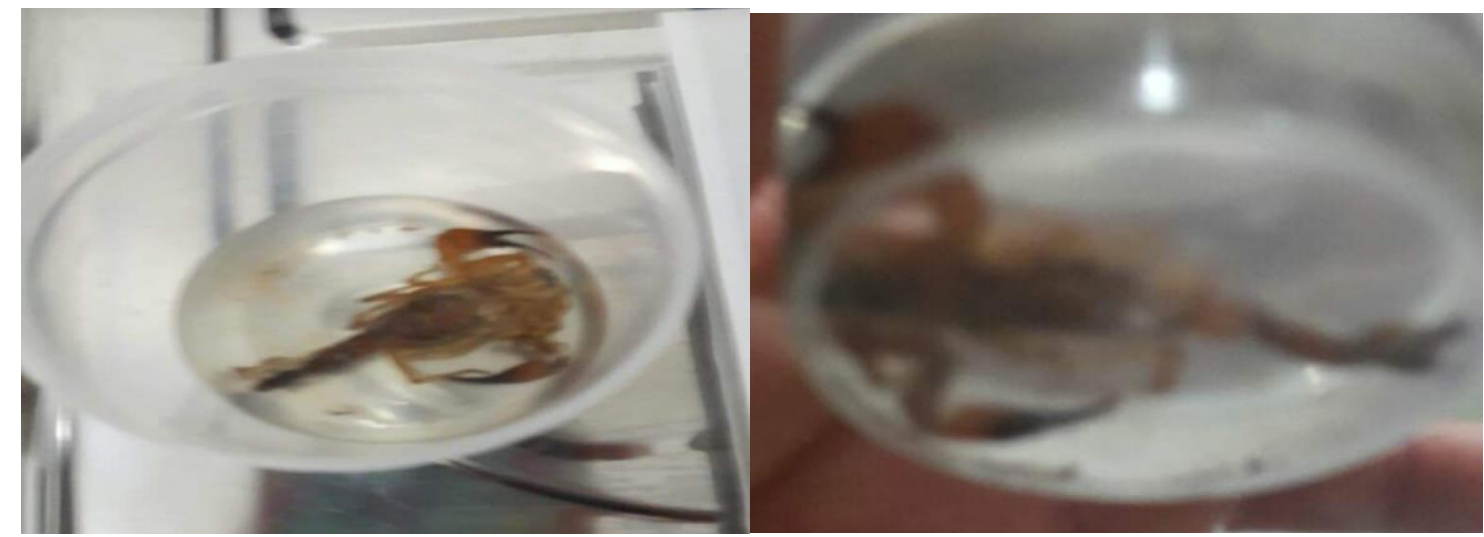

Fonte: Iraci Rocha (2017). Identificado por Bertani, R. Laboratório Especial de Ecologia e Evolução, Instituto Butantan, São Paulo, 2018.

Figura 08 - Tityus obscurus macho causador de acidente $\mathrm{n}^{\circ} 84$, no Travessão dos Baianos, zona rural, Rurópolis, 2017.
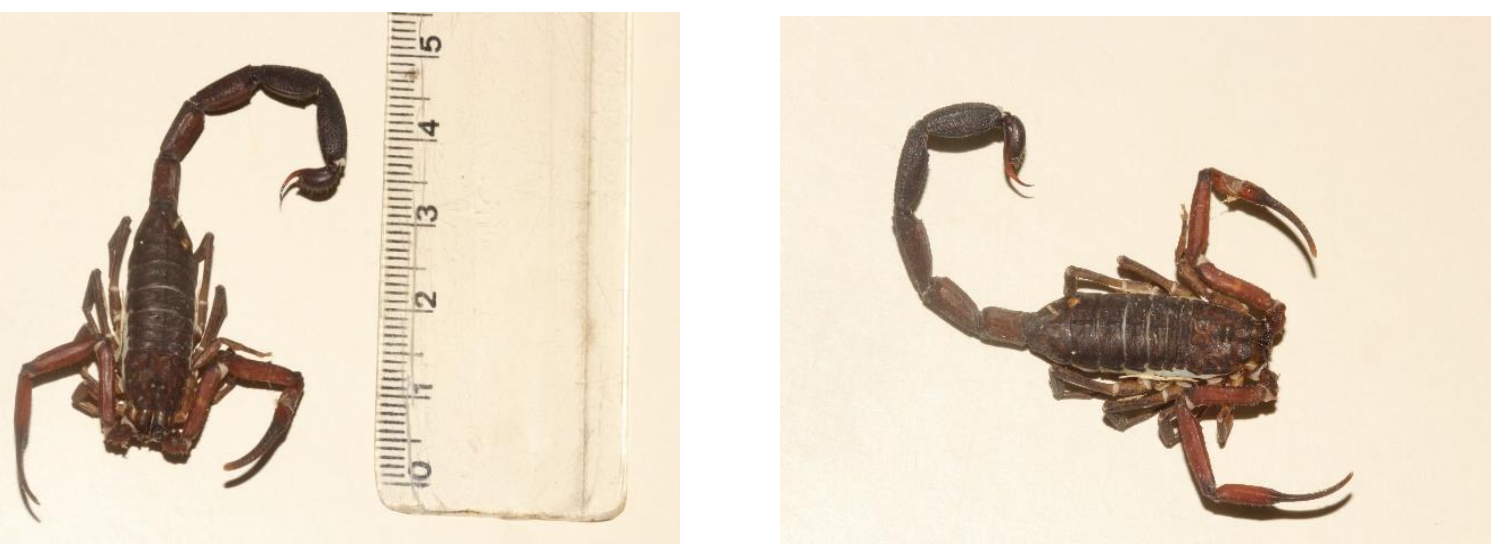

Fonte: Bertani, R. Laboratório Especial de Ecologia e Evolução, Instituto Butantan, São Paulo, 2017.

Figura 09 - Tityus obscurus fêmea causadora do acidente $n^{\circ}$ 96, na Vicinal da Eletronorte, zona rural, Rurópolis, 2017.
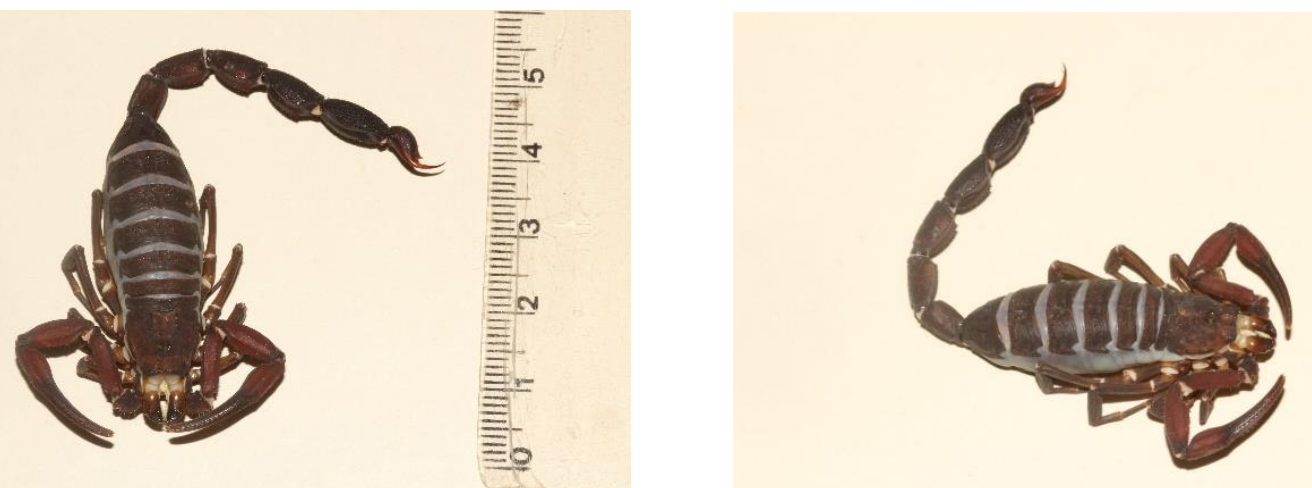

Fonte: Bertani, R. Laboratório Especial de Ecologia e Evolução, Instituto Butantan, São Paulo, 2017. 
Figura 10 - Tityus obscurus causador do acidente $n^{\circ} 113$, BR 230, Bairro Centro, zona urbana, Rurópolis, 2017.

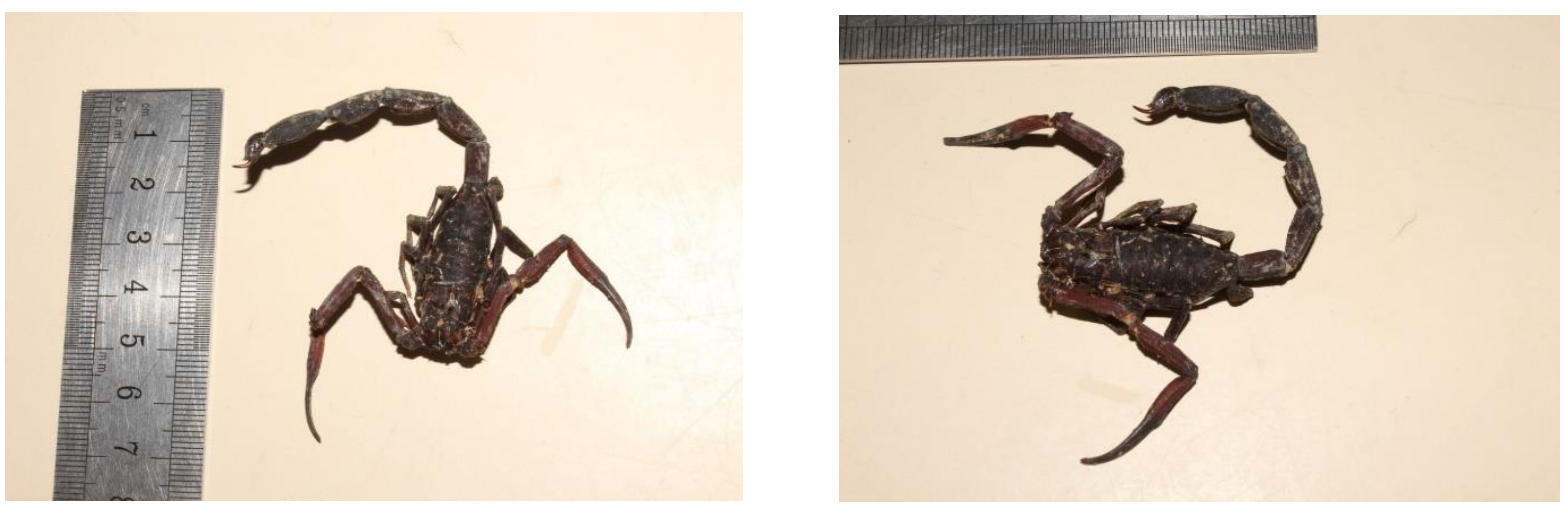

Fonte: Bertani, R. Laboratório Especial de Ecologia e Evolução, Instituto Butantan, São Paulo, 2017.

Figura 11 - Tityus obscurus fêmea causadora do acidente $\mathrm{n}^{\circ} 13$, carregando filhotes em seu dorso, Travessão das Águas Frias, BR 163, zona rural, Rurópolis, 2016.

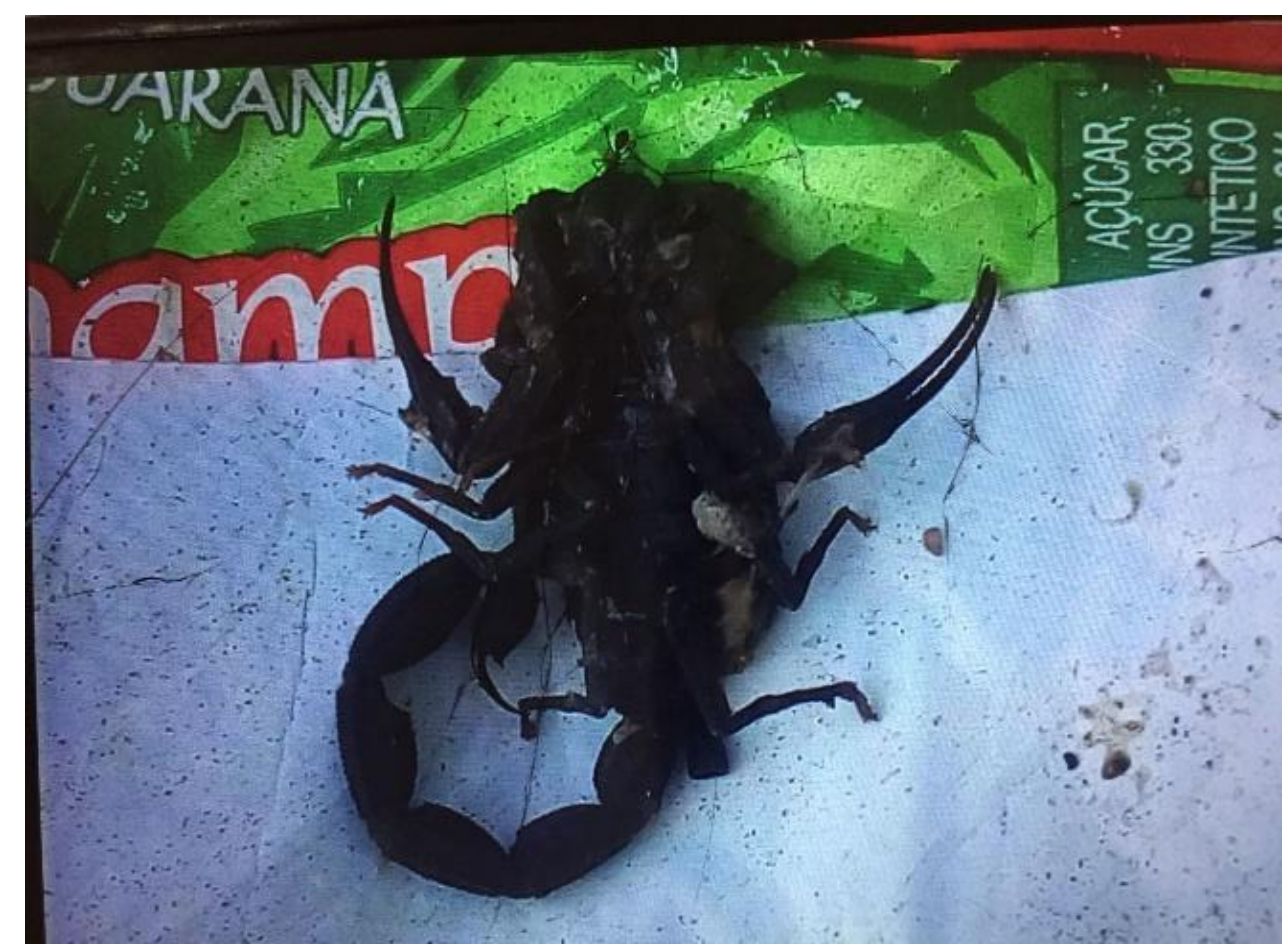

Fonte: Arquivo Hospital Municipal de Rurópolis. Identificado por Bertani, R. Laboratório Especial de Ecologia e Evolução, Instituto Butantan, São Paulo, 2018.

Dos acidentes causados por escorpião amarelo, um paciente proveniente da zona rural (Travessão do Peixotinho) trouxe o animal que foi encaminhado para identificação, porém o mesmo foi extraviado. Entretanto, mesmo com fotografia com baixa resolução retirada ainda na Unidade de Saúde do animal no recipiente, o Dr. Rogério Bertani, um dos 
maiores especialistas em artrópodes do Brasil, conseguiu identifica-lo como T. strandi, que até o presente momento ainda não estava elencado como escorpião de importância clínica.

A maioria dos acidentados $(70,94 \%)$ não realizou cuidados antes da chegada ao hospital, porém ainda existe uma parcela importante de $(26,06 \%)$ que realizou procedimentos como ingestão de substâncias diversas $(58,82 \%)$, seja de forma isolada $(41,17 \%)$ ou associada com outras práticas $(17,65 \%)$.

Entre as substâncias ingeridas o antiveneno fitoterápico denominado Específico Pessoa foi o mais utilizado (75\%), seguido de soluções caseiras (suco da malva do reino, semente e chá da castanha de caju) e bebida alcoólica (20\%) e ingestão de analgésico e antiinflamatório (5\%).

As substâncias aplicadas no local da picada foram as mais diversas: leite da castanha de caju, fel de paca, álcool, bebida alcoólica, gasolina, compressa com flor de graviola, limão morno, gel (arnica), gema de ovo, veneno de animal, cebola, vinagre e alho, gelo e fogo.

Há uma predominância na ingestão do "Específico Pessoa" que promete "cura infalível" a todos os casos de envenenamento, mas que não expõe claramente seus compostos em sua bula. Outra prática é o uso do torniquete que, apesar de ser amplamente divulgada a não recomendação em casos de acidentes por animais peçonhentos, ainda é aplicada pois esses cuidados são culturalmente aprendidos e difundidos ao longo dos anos entre as populações amazônidas.

Os dados revelam que o acidente escorpiônico é predominantemente diurno $(75,22 \%)$, sendo o matutino (06 às 12 horas) o período do dia com maior vulnerabilidade $(41,02 \%)$.

O membro superior foi o local com maior frequência de inoculação de veneno com $(58,13 \%)$ dos casos, sendo que o antebraço/braço foi o seguimento mais acometido $(26,50 \%)$. Em sua maioria, o acidente ocorreu na execução de afazeres (86,33\%), seja em trabalho $(50,43 \%)$ ou em tarefas cotidianas do $\operatorname{lar}(35,90 \%)$. Ressalta-se que o ambiente rural é o cenário mais frequente para este agravo $(78,64 \%)$ sendo $(45,30 \%)$ em área livre, $(27,35 \%)$ em domicílio e $(5,99 \%)$ em peridomicilio. 
Figura 12 - Distribuição espacial das vítimas de acidentes escorpiônicos no espaço rural do município de Rurópolis, Pará, no período de outubro de 2016 a setembro de 2017.

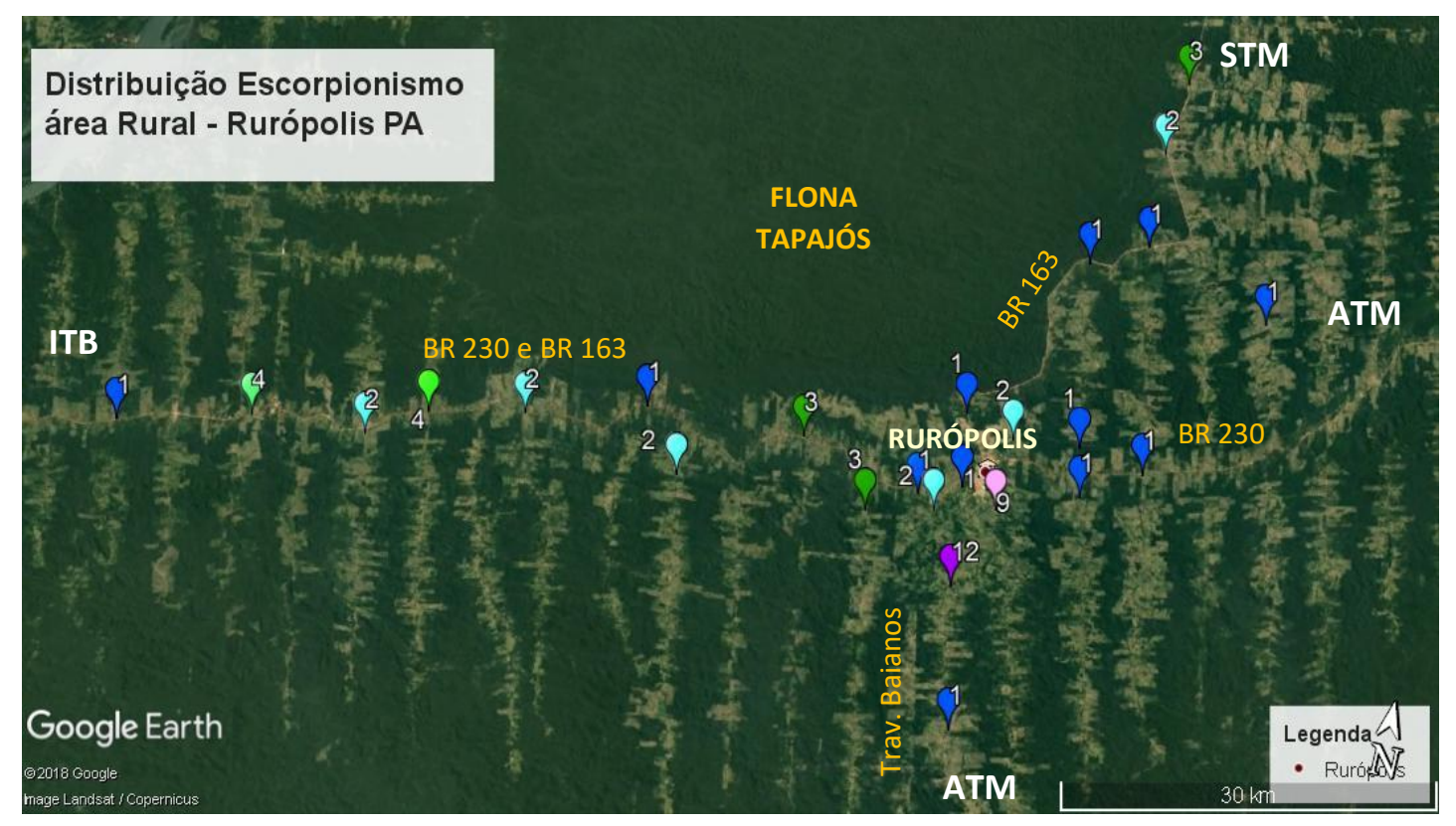

Fonte: Google Earth (2019).

Na figura 12 observa-se a distribuição espacial dos acidentes escorpiônicos ao longo das estradas BR 163 e BR 230, nos sentidos Itaituba (ITB), Santarém (STM) e Altamira (ATM) e na figura 5 observa-se a distribuição dos mesmos nos espaços urbanos e periurbanos. 
Figura 13 - Distribuição espacial das vítimas de acidentes escorpiônicos no espaço urbano e periurbano do município de Rurópolis, Pará, no período de outubro de 2016 a setembro de 2017.

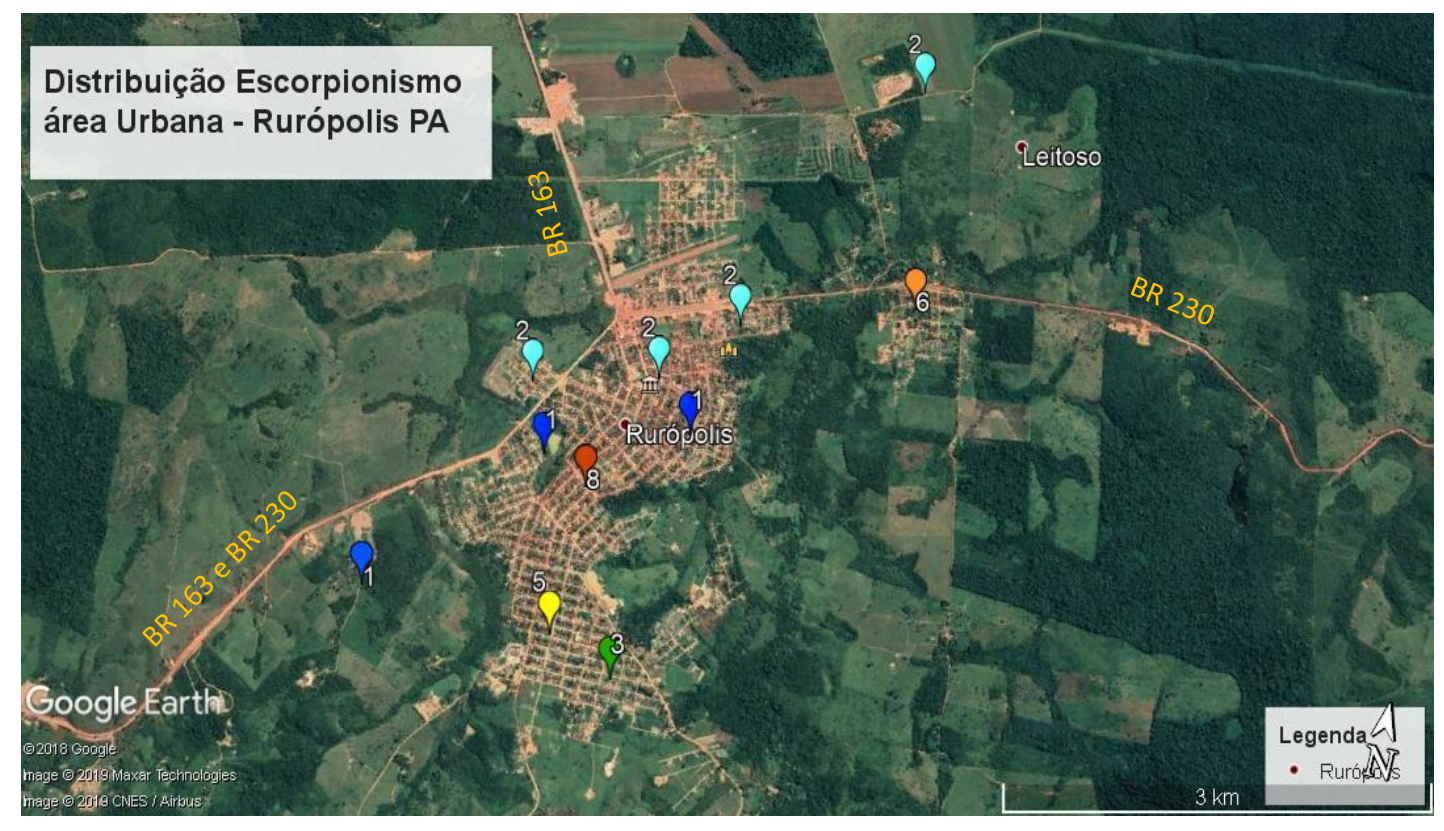

Fonte: Google Earth (2019).

Para melhor compreensão dos contextos do acidente, tornou-se necessária a apresentação de alguns dados sobre gênero e geração, apesar do homem adulto ser mais vulnerável ao escorpionismo, os contextos do acidente são diferentes para homens, mulheres, adultos e jovens como se percebe nos gráficos a seguir. 
Gráfico 02 - Distribuição das vítimas de acidentes escorpiônicos em Rurópolis, segundo local de ocorrência e sexo, outubro de 2016 a setembro de 2017.

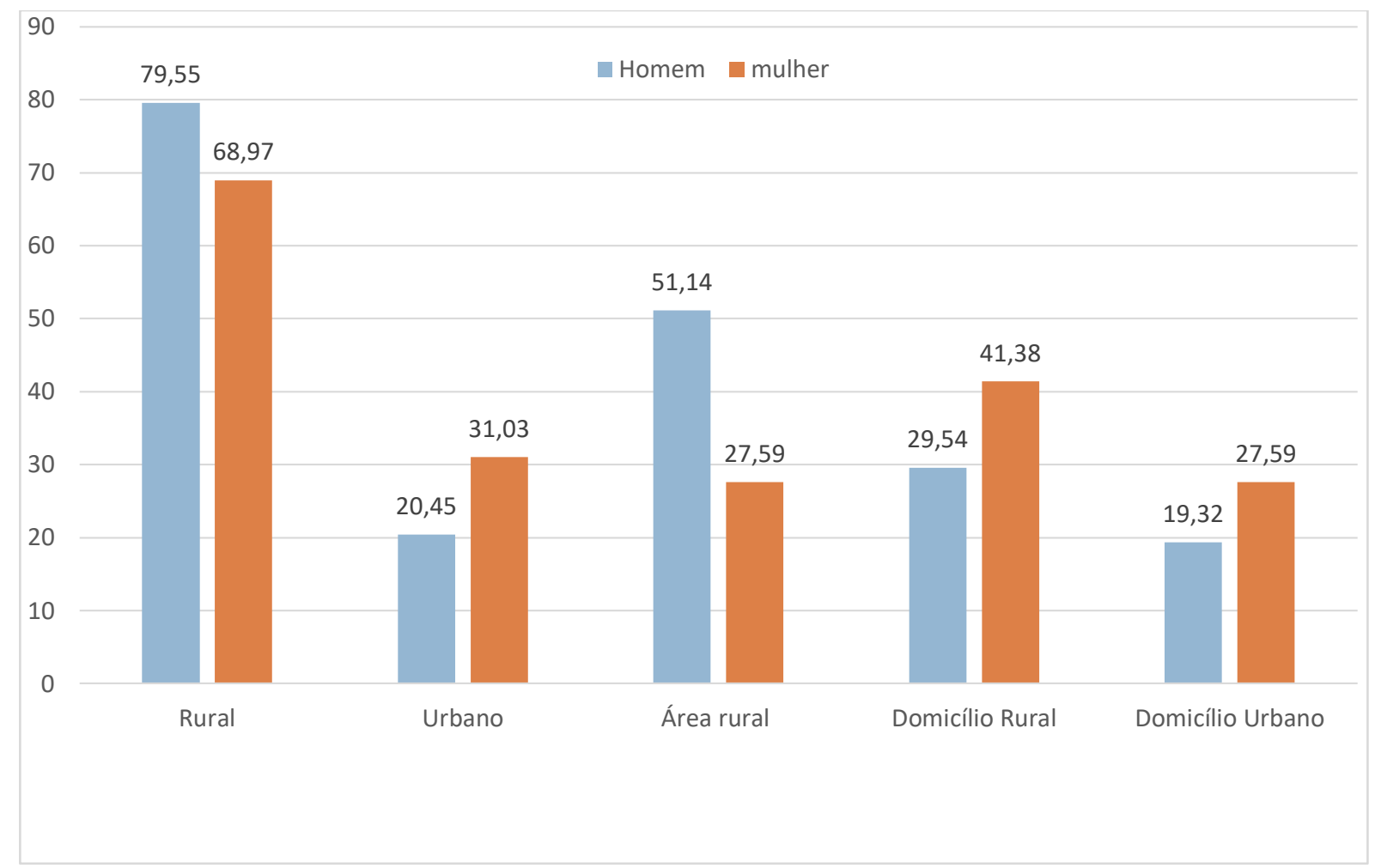

Os dados foram calculados a partir do número total de casos, segundo o sexo. As duas primeiras colunas, demonstram a prevalência de acidentes na zona rural em detrimento da zona urbana, nos dois gêneros. Porém, quando se analisa o local de ocorrência, percebe-se que o homem se acidenta mais na área rural enquanto a mulher se acidenta mais no domicílio, seja ele rural ou urbano. Observa-se que o domicílio é o local com maior ocorrência de acidentes $(52,99 \%)$, se somar os rurais e urbanos. 
Gráfico 03 - Distribuição das vítimas de acidentes escorpiônicos em Rurópolis, segundo contexto e sexo, outubro de 2016 a setembro de 2017.

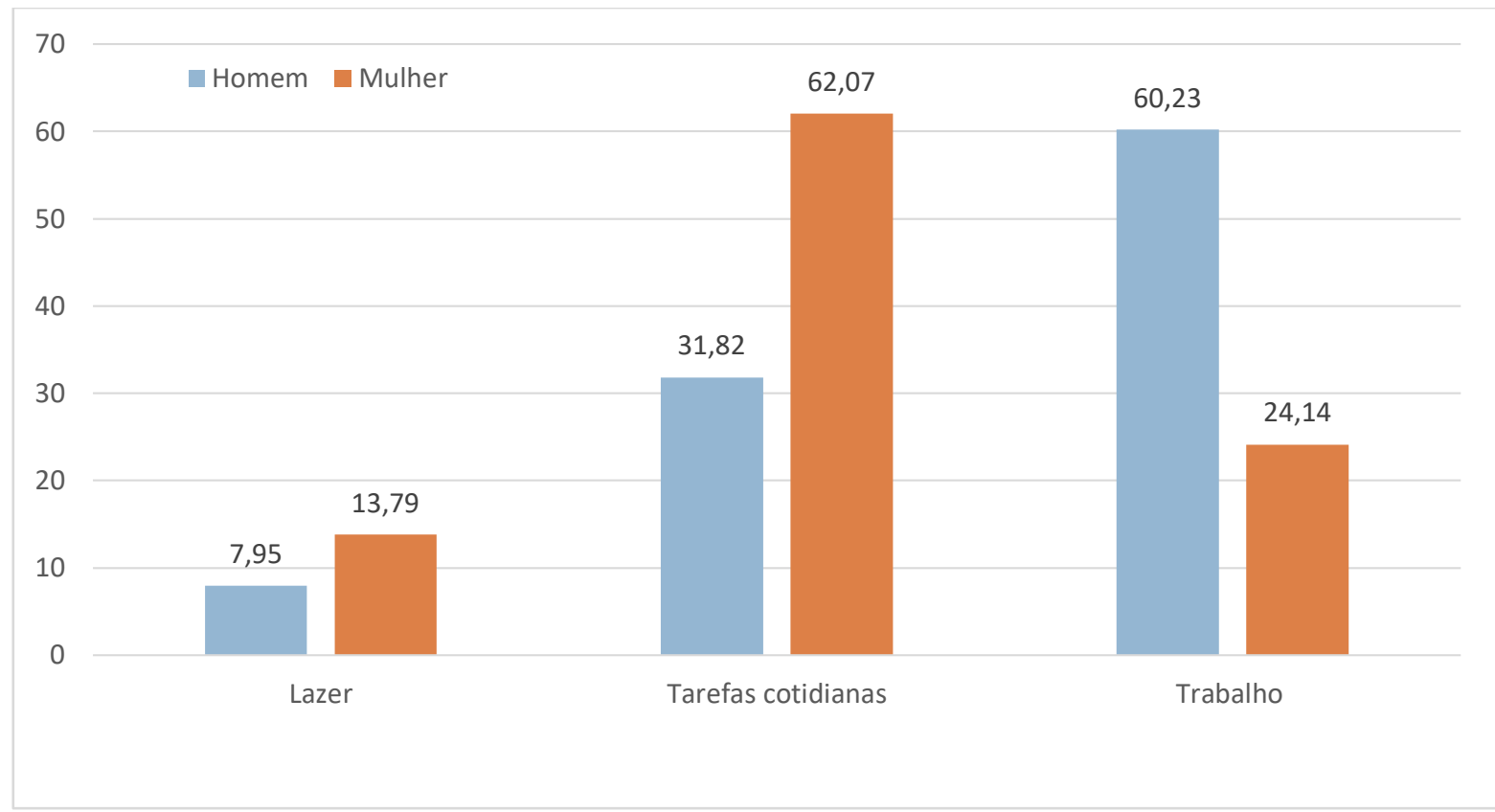

Em relação ao contexto em que aconteceu o acidente, percebe-se que há uma diferença importante pois enquanto as mulheres acidentam-se mais durante o lazer ou na execução de tarefas cotidianas, o homem se acidenta na execução do trabalho.

Gráfico 04 - Distribuição das crianças e jovens vítimas acidentes escorpiônicos em Rurópolis, segundo local de ocorrência e contexto, outubro de 2016 a setembro de 2017.

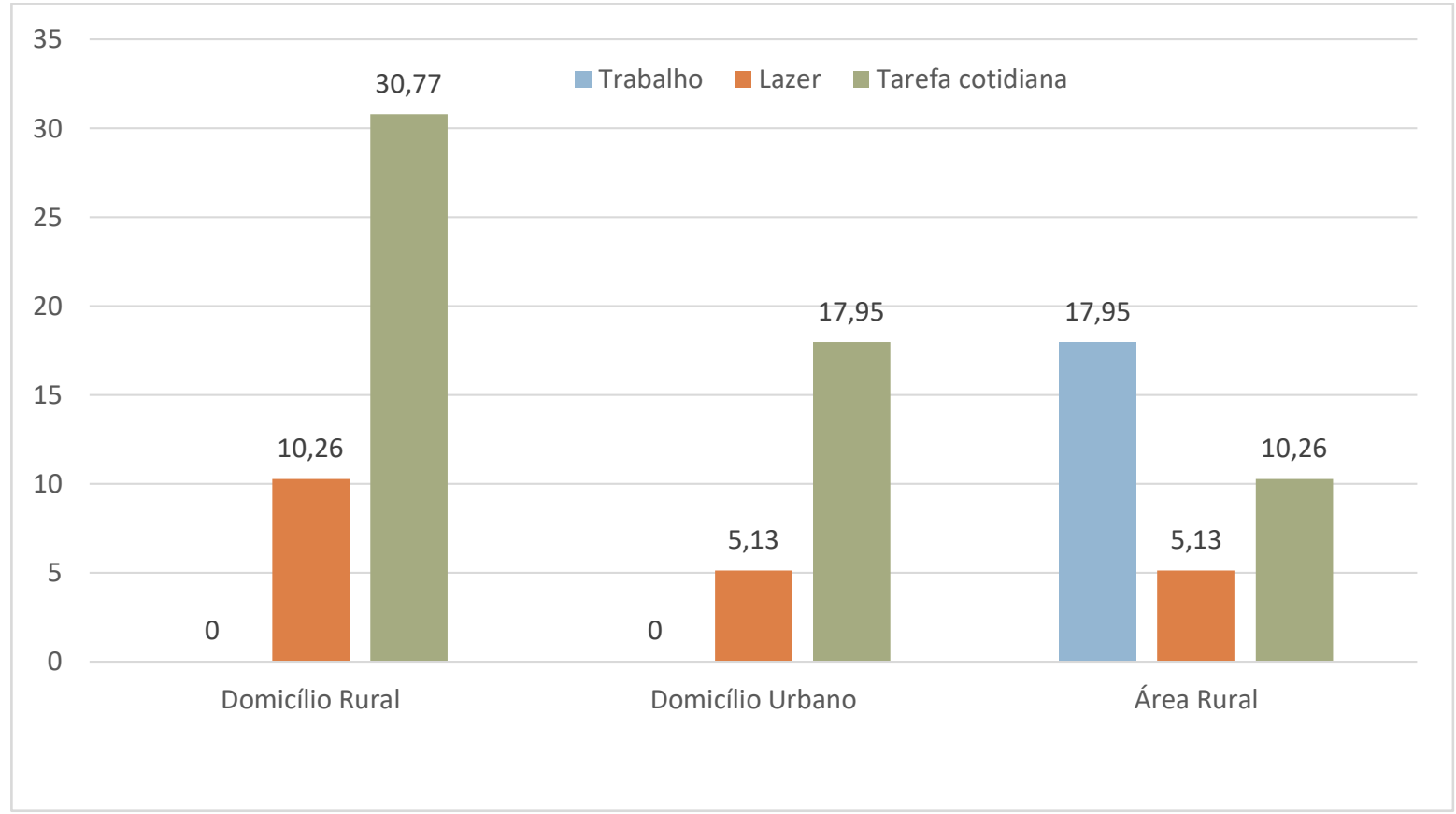


As crianças e jovens representaram $(29,05 \%)$ de todos os acidentados. Entre estes, os mais vulneráveis são os que habitam a zona rural $(74,37 \%)$ e, em outra análise, aqueles que realizam tarefa cotidiana e lazer em seus domicílios $(63,11 \%)$, sobretudo no âmbito rural $(41,03 \%)$. O contexto do trabalho esteve presente somente em acidentes em área rural $(17,95 \%)$ e foi relatado principalmente por jovens, mas também por crianças de 06 e 10 anos de idade.

Importa ressaltar que, neste estudo, consideram-se algumas tarefas cotidianas como contextos de trabalho, entretanto sem a conotação do ganho financeiro, como as atividades do lar (limpeza de casa, limpeza de quintal, lavagem de roupas, entre outros). Outras tarefas cotidianas relacionam-se a atividades de autocuidado e de necessidades fisiológicas (higienizarse, vestir-se, etc) e de trajetória (ir à escola, à igreja, ao trabalho).

\subsection{Caracterização clínica do escorpionismo}

Entre os 117 acidentados, um não apresentou manifestação clínica, sendo classificado como "picada seca" ou "dry bite". Trata-se do caso 3, C.N.N.L, 03 anos de idade, sexo masculino, pardo, morador de casa de alvenaria, no Travessão da Perdida, na zona rural. Apresenta IMC adequado e sua genitora nega qualquer tipo de antecedentes mórbidos. Foi picado no dia 21 de outubro de 2016, às 12 horas (chegando após 01 hora do acidente), em seu domicílio, enquanto tomava banho, um "escorpião marrom” o picou no glúteo esquerdo. Como sinais vitais, a pressão arterial 100x60 mmHg, temperatura axilar $36,8^{\circ} \mathrm{C}$, frequência respiratória 15 movimentos respiratórios por minuto e frequência cardíaca 72 batimentos por minuto.

A criança permaneceu em observação por 12 horas, o caso foi notificado e todos os procedimentos de rotina foram realizados. A família levou o animal ao serviço de saúde, ainda que não estivesse vivo e sem parte da cauda (Fotografia 06). O escorpião seguiu para identificação, apesar da inexistência da parte distal da cauda, evidências morfológicas sugerem se tratar de uma amostra de escorpião jovem de Tityus obscurus.

Entre os 116 pacientes que apresentaram manifestações clínicas, 93 (79,49\%) apresentaram manifestações clínicas locais e 97 (82,91\%) apresentaram manifestações clínicas sistêmicas. Analisando a distribuição dos sinais e sintomas, pode-se constatar que 19 pacientes apresentaram apenas sintomas locais, 23 apresentaram apenas sintomas sistêmicos e 74 apresentaram manifestações locais e sistêmicas concomitantemente. 
Gráfico 05 - Distribuição das vítimas de acidentes escorpiônicos em Rurópolis, segundo manifestações clínicas, outubro de 2016 a setembro de 2017.

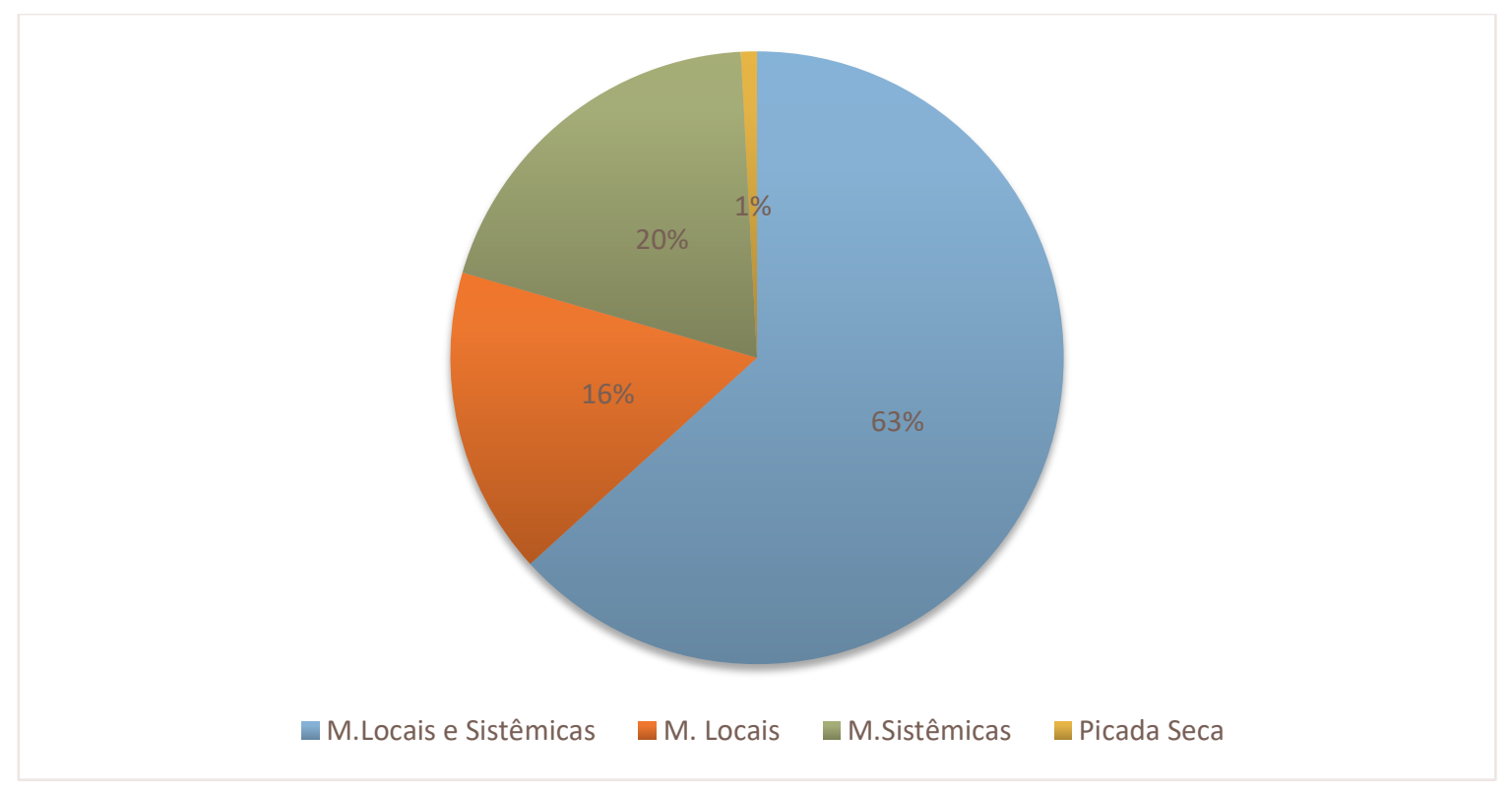

Entre as manifestações locais, a dor foi o principal e mais frequente com $(70,09 \%)$ dos casos, seguido de parestesia (referido como formigamento) com $(16,24 \%)$, edema $(13,68 \%)$, sensação de choque elétrico $(06,13 \%)$, calor local $(03,42 \%)$ e eritema $(0,85 \%)$ (Gráfico 6$)$

Gráfico 06 - Distribuição das vítimas de acidentes escorpiônicos em Rurópolis, segundo manifestações clínicas locais, outubro de 2016 a setembro de 2017.

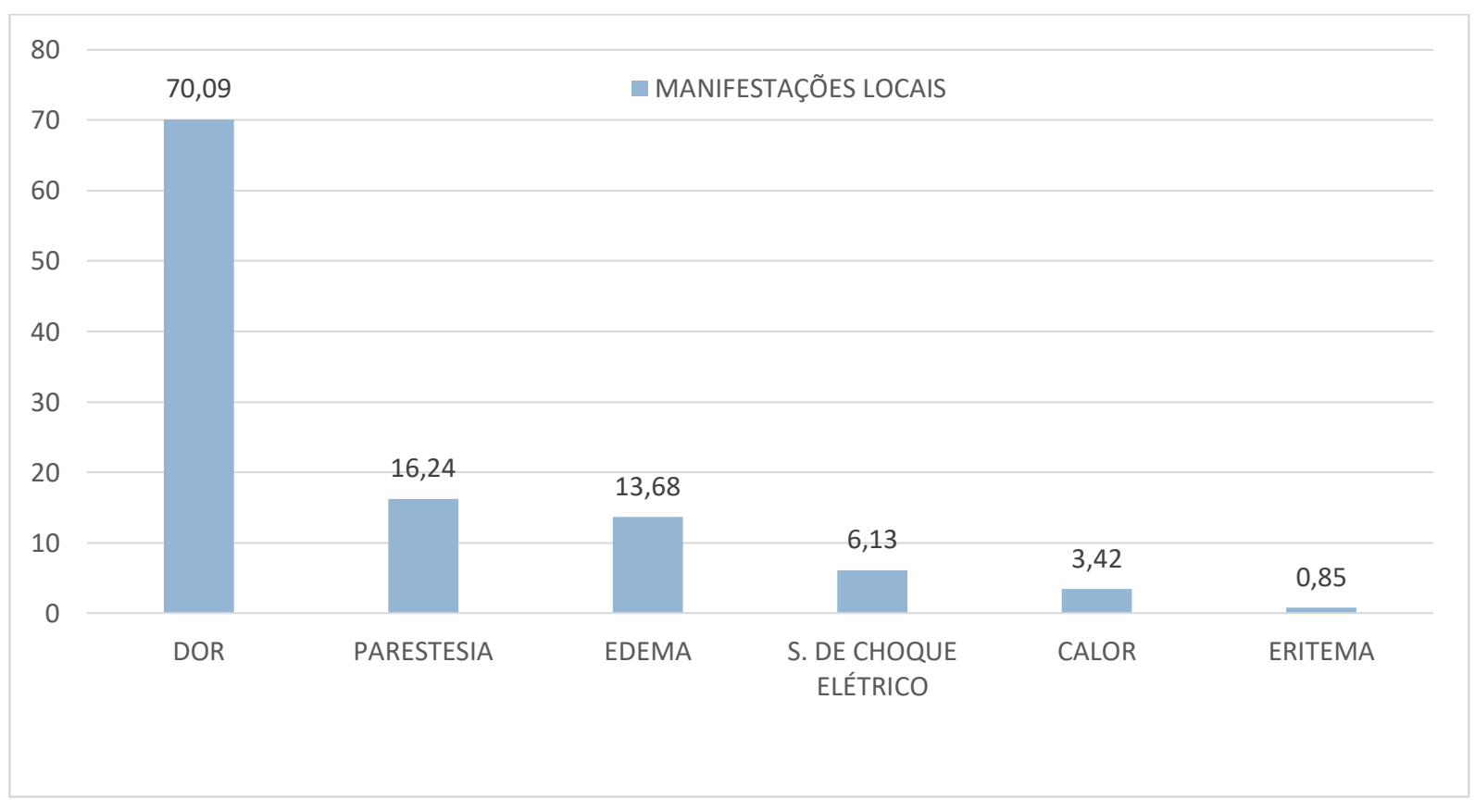


O acompanhamento dos casos clínicos permitiu melhor descrição dos sintomas considerados locais, como a dor e a parestesia, mas que no decorrer da pesquisa se percebeu que podem tomar proporções corporais, permitindo a constatação de que esses sintomas podem ser classificados como locais ou sistêmicos.

Esses sintomas foram observados quanto o tempo que levou para iniciar após a inoculação do veneno, o tempo que durou a manifestação clínica e a extensão corporal sentida pelo paciente, sendo classificada em local, regional e sistêmica (Tabela 04). Considera-se um sintoma regional aquele que se limita a acometer o membro envolvido no acidente enquanto que o sintoma sistêmico se prolonga pelo hemicorpo afetado, tronco ou toma proporção corporal total.

Tabela 04 - Distribuição das vítimas de acidentes escorpiônicos no município de RurópolisPA, segundo tempo para início, duração e localização dos sintomas Dor, Parestesia e Sensação de Choque Elétrico, outubro de 2016 a setembro de 2017.

\begin{tabular}{|c|c|c|c|c|c|c|c|c|}
\hline \multirow[t]{2}{*}{ SINTOMA } & \multirow[t]{2}{*}{$\mathrm{N}^{\mathrm{o}}$} & \multirow[t]{2}{*}{$\%$} & \multicolumn{2}{|c|}{ INÍCIO SINTOMA } & \multicolumn{2}{|l|}{$\begin{array}{l}\text { DURAÇÃO } \\
\text { SINTOMA }\end{array}$} & \multicolumn{2}{|c|}{$\begin{array}{c}\text { LOCAL } \\
\text { AFETADO }\end{array}$} \\
\hline & & & Tempo & $\%$ & Tempo & $\%$ & Localização & $\%$ \\
\hline Dor & 112 & 95,73 & $\begin{array}{l}\text { Imediato } \\
<30 \mathrm{~min} \\
>30 \mathrm{~min}<01 \mathrm{~h} \\
>01 \mathrm{~h}<02 \mathrm{~h} \\
>02 \mathrm{~h}<04 \mathrm{~h} \\
\text { Sem Informação }\end{array}$ & $\begin{array}{l}94,64 \\
02,68 \\
00,00 \\
00,00 \\
00,89 \\
01,79\end{array}$ & $\begin{array}{l}\text { Até } 06 \mathrm{~h} \\
>06 \mathrm{~h}<12 \mathrm{~h} \\
>12 \mathrm{~h}<24 \mathrm{~h} \\
>24 \mathrm{~h}<48 \mathrm{~h} \\
\text { Sem } \\
\text { Informação }\end{array}$ & $\begin{array}{l}34,82 \\
34,82 \\
23,22 \\
04,46 \\
02,68\end{array}$ & $\begin{array}{l}\text { Local } \\
\text { Regional } \\
\text { Sistêmico }\end{array}$ & $\begin{array}{l}72,32 \\
20,54 \\
07,14\end{array}$ \\
\hline Parestesia & 90 & 76,92 & $\begin{array}{l}\text { Imediato } \\
<30 \mathrm{~min} \\
>30 \mathrm{~min}<01 \mathrm{~h} \\
>01 \mathrm{~h}<02 \mathrm{~h} \\
>02 \mathrm{~h}<04 \mathrm{~h} \\
>04 \mathrm{~h}\end{array}$ & $\begin{array}{l}12,22 \\
34,45 \\
16,67 \\
23,33 \\
11,11 \\
02,22\end{array}$ & $\begin{array}{l}\text { Até } 06 \mathrm{~h} \\
>06 \mathrm{~h}<12 \mathrm{~h} \\
>12 \mathrm{~h}<24 \mathrm{~h} \\
>24 \mathrm{~h}<48 \mathrm{~h}\end{array}$ & $\begin{array}{l}05,55 \\
40,00 \\
44,45 \\
10,00\end{array}$ & $\begin{array}{l}\text { Local } \\
\text { Regional } \\
\text { Sistêmico }\end{array}$ & $\begin{array}{l}20,00 \\
20,00 \\
60,00\end{array}$ \\
\hline $\begin{array}{l}\text { Sensação de } \\
\text { Choque } \\
\text { Elétrico }\end{array}$ & 89 & 76,07 & $\begin{array}{l}\text { Imediato } \\
<30 \mathrm{~min} \\
>30 \mathrm{~min}<01 \mathrm{~h} \\
>01 \mathrm{~h}<02 \mathrm{~h} \\
>02 \mathrm{~h}<04 \mathrm{~h} \\
>04 \mathrm{~h}\end{array}$ & $\begin{array}{l}07,87 \\
38,20 \\
25,84 \\
15,73 \\
08,99 \\
03,37 \\
\end{array}$ & $\begin{array}{l}\text { Até } 06 \mathrm{~h} \\
>06 \mathrm{~h}<12 \mathrm{~h} \\
>12 \mathrm{~h}<24 \mathrm{~h} \\
>24 \mathrm{~h}<48 \mathrm{~h}\end{array}$ & $\begin{array}{l}08,99 \\
35,96 \\
48,32 \\
06,74\end{array}$ & $\begin{array}{l}\text { Local } \\
\text { Regional } \\
\text { Sistêmico }\end{array}$ & $\begin{array}{l}06,74 \\
19,10 \\
74,16\end{array}$ \\
\hline
\end{tabular}

A dor foi o sintoma mais frequente entre os acidentados (95,73\%), que surgiu de forma imediata $(94,64 \%)$, levando em média 2 minutos e 13 segundos para se manifestar e evoluindo também de forma imediata em intensidade e na extensão de localização $(75,89 \%)$. Sua manifestação pode durar por 10 minutos ou até mesmo 48 horas, tendo a média de duração de 12 horas e 28 minutos. A maioria dos pacientes afirmou que o sintoma desapareceu nas primeiras 06 horas $(34,82 \%)$. 
Dentre os pacientes que referiram dor, a maioria dos casos $(72,32 \%)$ referiu o sintoma limitado ao local da inoculação do veneno, entretanto, em alguns pacientes, o sintoma evoluiu de forma sistêmica $(27,68 \%)$. A dor sistêmica se manifestou com intensidade de forma crescente $(18,75 \%)$, chegando a acometer o membro afetado $(20,54 \%)$ ou mesmo toda superfície corpórea $(07,14 \%)$.

Diferentemente da dor, a parestesia se manifestou majoritariamente como sintoma sistêmico $(80,00 \%)$. Na maioria dos pacientes, ela surgiu em até 01 hora após a picada do escorpião (51,12\%), com tempo médio de 01 hora e 15 minutos para se manifestar, evoluindo de forma crescente $(82,22 \%)$, chegando a acometer todo seguimento corporal $(60,00 \%)$. O sintoma se manifestou com duração mínima de 4 horas e máxima de 48 horas, com tempo médio de 17 horas e 59 minutos de manifestação.

Gráfico 07 - Distribuição das vítimas de acidentes escorpiônicos no município de RurópolisPA, segundo tempo para início dos sintomas dor, parestesia e sensação de choque elétrico, outubro de 2016 a setembro de 2017.

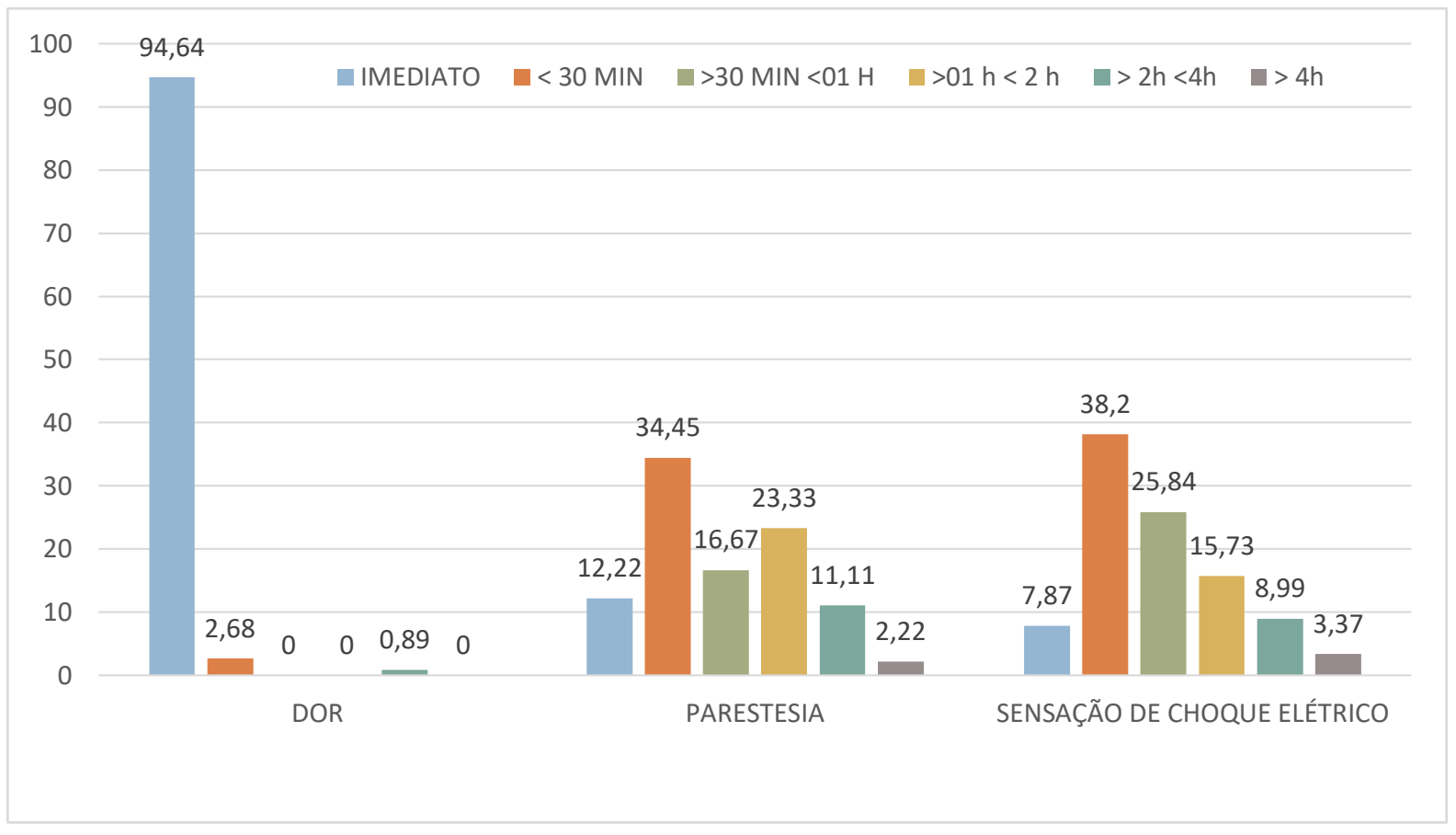

A sensação de choque elétrico se apresenta de forma semelhante à parestesia, com maioria de forma sistêmica $(93,26 \%)$, se apresentando em 89 (76,07\%) dos 117 pacientes desta pesquisa. O sintoma se apresentou em até 01 hora (64,04\%), com média de tempo de 1 hora e 13 minutos para se manifestar. A maioria evolui de forma crescente $(89,89 \%)$ e sua maior proporção acomete todo corpo do paciente $(74,16 \%)$ e que perduram por 12 a 24 horas 
(48,32\%). O tempo mínimo foi de 40 minutos e o tempo máximo referido foi de 48 horas, com média do tempo de duração de 16 horas e 23 minutos.

A análise do gráfico 07 permite constatar que, dentre os sintomas apresentados, a dor é o que se manifesta mais rapidamente $(96,46 \%)$ e que não tarda a se apresentar. Diferentemente da dor, a parestesia e a sensação de choque elétrico, apesar de mais de 30\% dos casos apresentar os sintomas em até meia hora, os pacientes ainda ficaram propensos a manifestar esses sintomas mesmo após decorridas 10 horas da picada.

Apesar da dor estar presente praticamente em todos os casos de escorpionismo e evoluir de forma mais rápida nos pacientes, é o sintoma que tem menor duração entre os sintomas analisados, cessando em média até 12 horas $(67,26 \%)$. Em contraponto, a parestesia e a sensação de choque elétrico duram em média 17 e 16 horas, respectivamente, e em mais de $80 \%$ dos casos perduram pelo período de 06 a 24 horas (Gráfico 08)

Gráfico 08 - Distribuição das vítimas de acidentes escorpiônicos no município de Rurópolis, PA, segundo tempo de duração dos sintomas Dor, Parestesia e Sensação de Choque Elétrico, outubro de 2016 a setembro de 2017.

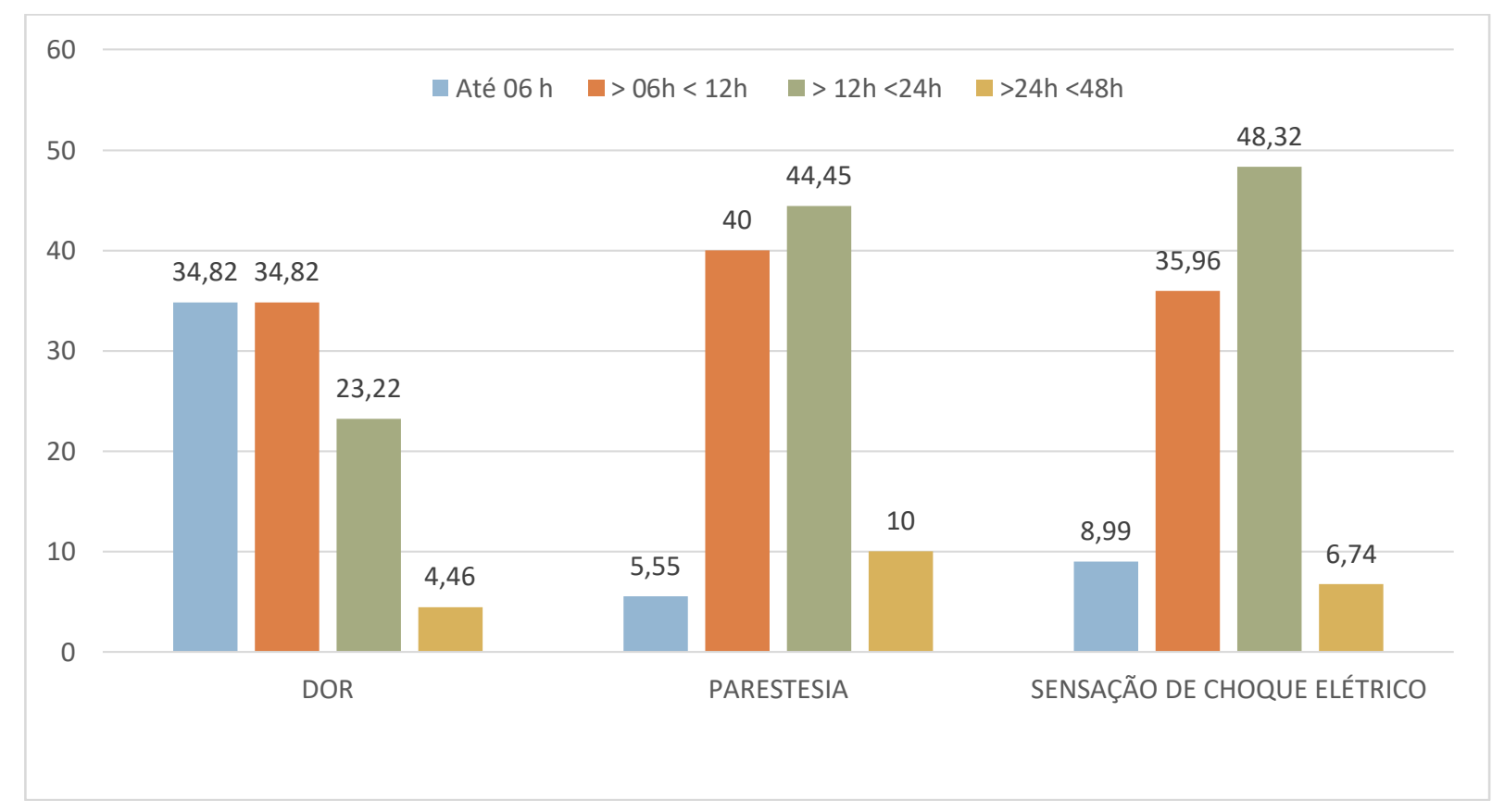

Importa relatar que alguns pacientes referiram que a sensação de choque elétrico não desaparecia completamente, bastava um simples toque no local afetado que o paciente voltava a senti-lo. Outros afirmaram que esta sensação piorava ao entrar em contato com água (ao tomar banho).

Em relação à extensão corporal afetada pelo sintoma, esta pesquisa comprovou que estes se manifestam além do local da picada podendo acometer toda superfície corporal. Este dado 
leva a constatar que dor, parestesia e sensação de choque elétrico devem ser considerados tanto manifestações clínicas locais quanto sistêmicas.

É importante observar que a manifestação da dor se comporta diferente dos outros dois sintomas, que se manifestam de forma similar. No gráfico 09, percebe-se que a dor é predominantemente uma manifestação local $(72,32 \%)$, enquanto que a parestesia $(20,00 \%)$ e a sensação de choque elétrico $(06,74 \%)$. Em contraponto, a parestesia e a sensação de choque elétrico se manifestam predominantemente de forma sistêmica pois, na maioria dos casos, se apresenta em toda superfície corporal, com $60,00 \%$ e $74,16 \%$, respectivamente.

Gráfico 09 - Distribuição das vítimas de acidentes escorpiônicos no município de RurópolisPA, segundo localização dos sintomas Dor, Parestesia e Sensação de Choque Elétrico, outubro de 2016 a setembro de 2017.

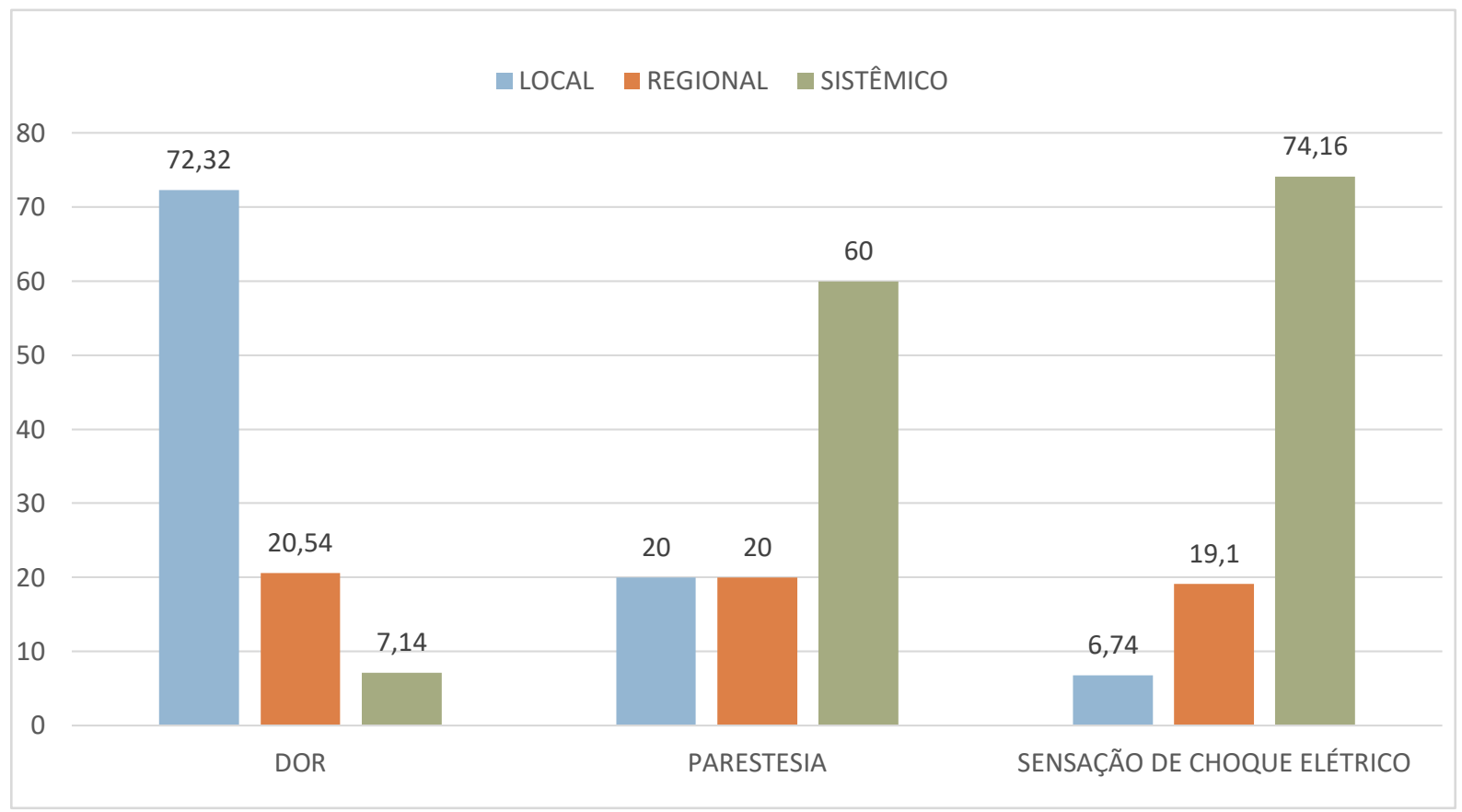


Em relação à dor, durante a avaliação dos pacientes foi utilizada a Escala Visual Analógica - EVA, em que o paciente pode classificar o sintoma como dor leve (score 0-2), moderada (score 3-7) ou intensa (8-10), cujo resultado se avalia no Gráfico 10.

Gráfico 10 - Distribuição das vítimas de acidentes escorpiônicos no município de RurópolisPA, segundo intensidade da Dor, outubro de 2016 a setembro de 2017.

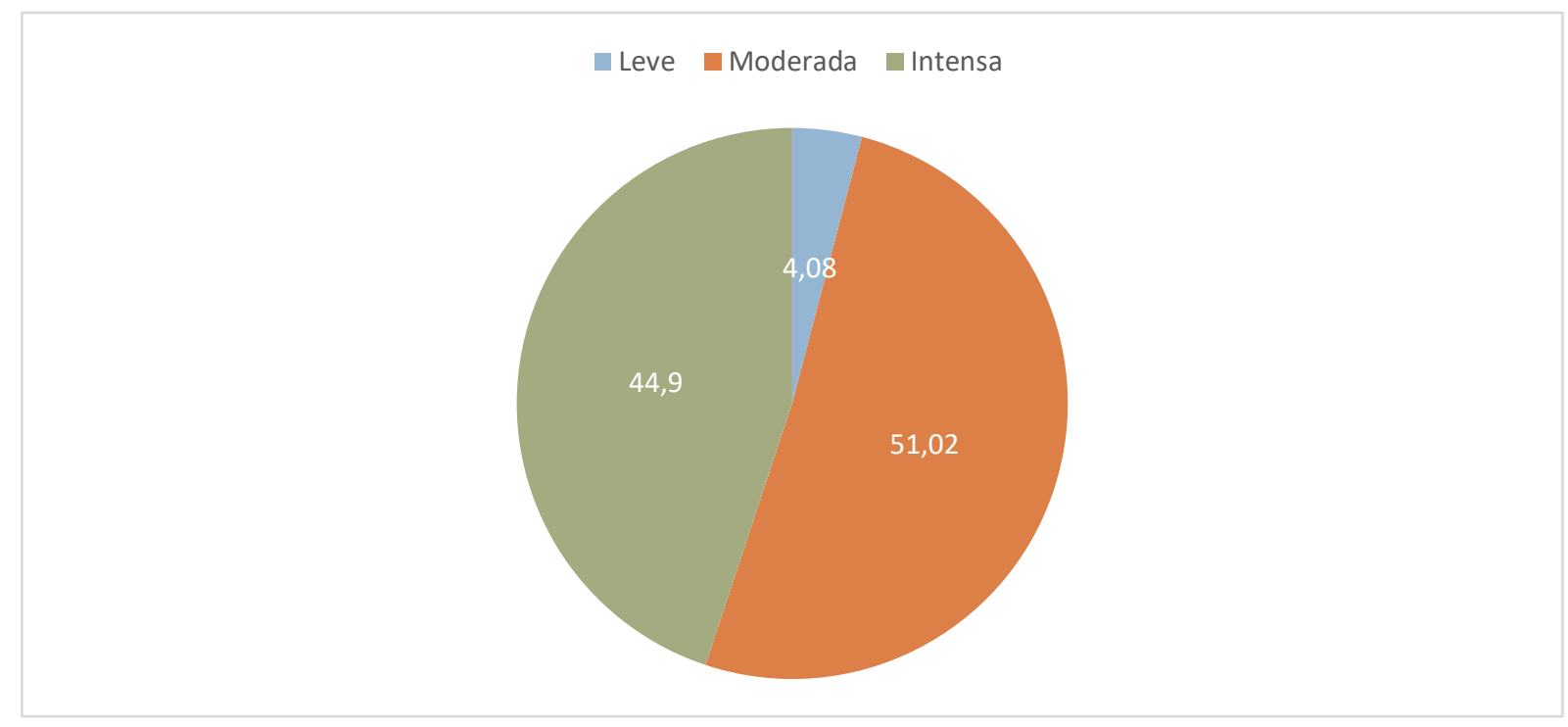

Neste estudo, $(4,08 \%)$ dos pacientes referiram dor leve, $(51,02 \%)$ dor moderada e $(44,90 \%)$ dor intensa. O valor médio atribuído pelos pacientes foi de 7,16 que corresponde a uma dor moderada.

O acidente escorpiônico em Rurópolis apresenta algumas peculiaridades em suas manifestações sistêmicas, principalmente, neuromusculares, oftalmológicas, cardiovasculares, gastrointestinais e urinárias. Os dados apresentados adiante foram calculados com base no número total de pacientes.

As manifestações neuromusculares se apresentaram de forma exuberante nesses casos de escorpionismo. Entre elas, destacaram-se a sensação de choque elétrico (72,65\%), parestesia $(61,54 \%)$, disartria $(40,17 \%)$, mioclonia $(33,33 \%)$, ataxia de marcha $(38,46 \%)$ e dismetria $(34,19 \%)$. Como os dois primeiros sintomas já foram apresentados, a Tabela 05 apresentará os demais sintomas. 
Tabela 05 - Distribuição das vítimas de acidentes escorpiônicos no município de RurópolisPA, segundo tempo para início e duração dos sintomas disartria, mioclonia, ataxia e dismetria, outubro de 2016 a setembro de 2017.

\begin{tabular}{|c|c|c|c|c|c|c|}
\hline MANIFESTAÇÃO & $\mathrm{N}^{\mathrm{o}}$ & $\%$ & \multicolumn{2}{|c|}{ INÍCIO DO SINTOMA } & \multicolumn{2}{|c|}{ DURAÇÃO DO SINTOMA } \\
\hline $\begin{array}{l}\text { Manifestações } \\
\text { Neuromusculares }\end{array}$ & & & Tempo & $\%$ & Tempo & $\%$ \\
\hline Disartria & 47 & 40,17 & $\begin{array}{l}\text { Imediato } \\
<30 \mathrm{~min} \\
>30 \mathrm{~min}<01 \mathrm{~h} \\
>01 \mathrm{~h}<02 \mathrm{~h} \\
>02 \mathrm{~h}<04 \mathrm{~h} \\
>04 \mathrm{~h}\end{array}$ & $\begin{array}{l}06,38 \\
08,51 \\
36,17 \\
21,28 \\
21,28 \\
06,38\end{array}$ & $\begin{array}{l}\text { Até } 06 \mathrm{~h} \\
>06 \mathrm{~h}<12 \mathrm{~h} \\
>12 \mathrm{~h}<24 \mathrm{~h} \\
>24 \mathrm{~h}<48 \mathrm{~h} \\
\text { Sem Informação }\end{array}$ & $\begin{array}{l}04,26 \\
38,29 \\
46,81 \\
08,51 \\
02,13\end{array}$ \\
\hline Mioclonia & 39 & 33,33 & $\begin{array}{l}\text { Imediato } \\
<30 \mathrm{~min} \\
>30 \mathrm{~min}<01 \mathrm{~h} \\
>01 \mathrm{~h}<02 \mathrm{~h} \\
>02 \mathrm{~h}<04 \mathrm{~h} \\
>04 \mathrm{~h}\end{array}$ & $\begin{array}{l}12,82 \\
30,77 \\
20,51 \\
17,95 \\
10,26 \\
07,69\end{array}$ & $\begin{array}{l}\text { Até 06h } \\
>06 \mathrm{~h}<12 \mathrm{~h} \\
>12 \mathrm{~h}<24 \mathrm{~h} \\
>24 \mathrm{~h}<48 \mathrm{~h} \\
\text { Sem Informação }\end{array}$ & $\begin{array}{l}10,26 \\
38,46 \\
41,03 \\
02,56 \\
07,69\end{array}$ \\
\hline Ataxia de Marcha & 45 & 38,46 & $\begin{array}{l}\text { Imediato } \\
<30 \mathrm{~min} \\
>30 \mathrm{~min}<01 \mathrm{~h} \\
>01 \mathrm{~h}<02 \mathrm{~h} \\
>02 \mathrm{~h}<04 \mathrm{~h} \\
>04 \mathrm{~h}\end{array}$ & $\begin{array}{l}06,67 \\
11,11 \\
33,33 \\
24,45 \\
22,22 \\
02,22\end{array}$ & $\begin{array}{l}\text { Até } 06 \mathrm{~h} \\
>06 \mathrm{~h}<12 \mathrm{~h} \\
>12 \mathrm{~h}<24 \mathrm{~h} \\
>24 \mathrm{~h}<48 \mathrm{~h}\end{array}$ & $\begin{array}{l}02,22 \\
35,56 \\
55,56 \\
06,66\end{array}$ \\
\hline Dismetria & 40 & 34,19 & $\begin{array}{l}\text { Imediato } \\
<30 \mathrm{~min} \\
>30 \mathrm{~min}<01 \mathrm{~h} \\
>01 \mathrm{~h}<02 \mathrm{~h} \\
>02 \mathrm{~h}<04 \mathrm{~h}\end{array}$ & $\begin{array}{l}07,50 \\
12,50 \\
35,00 \\
22,50 \\
22,50\end{array}$ & $\begin{array}{l}\text { Até } 06 \mathrm{~h} \\
>06 \mathrm{~h}<12 \mathrm{~h} \\
>12 \mathrm{~h}<24 \mathrm{~h} \\
>24 \mathrm{~h}<48 \mathrm{~h}\end{array}$ & $\begin{array}{l}00,00 \\
32,50 \\
57,50 \\
10,00\end{array}$ \\
\hline
\end{tabular}

A tabela 05 apresenta os principais sintomas envolvidos na disfunção cerebelar aguda causada pelo escorpionismo. No entanto, para melhor compreensão, seguem gráficos apresentando os dados de forma mais detalhada. 
Gráfico 11 - Distribuição das vítimas de acidentes escorpiônicos no município de RurópolisPA, segundo tempo para início dos sintomas disartria, mioclonia, ataxia e dismetria, outubro de 2016 a setembro de 2017.

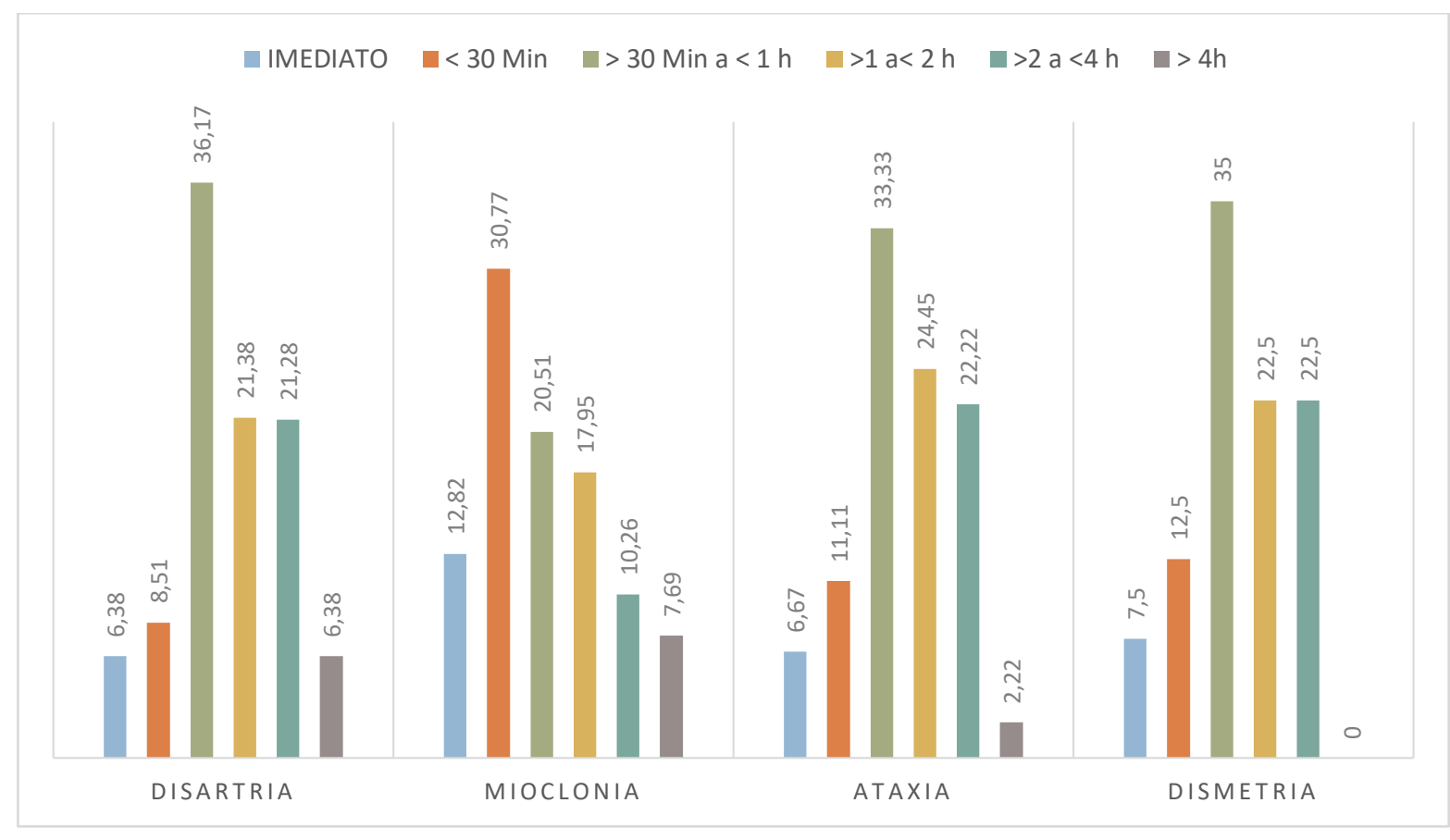

A disartria surgiu em até 01 hora após o acidente $(51,06 \%)$ na maioria dos casos, registrando-se a ocorrência de início imediato até o máximo de 06 horas após a picada do escorpião, obtendo-se uma média aproximada de 01 hora e 52 minutos para se manifestar.

A mioclonia se manifesta, predominantemente, em até 01 hora $(64,10 \%)$ após escorpionismo. Na maioria dos casos, sua evolução foi crescente $(87,18 \%, 83 \%)$ em que os segmentos corporais vão sendo acometidos paulatinamente, porém existindo relatos de evoluir de forma imediata em que os segmentos corporais são acometidos simultaneamente e imediatos à inoculação do veneno $(12,82 \%)$. O sintoma foi sentido no corpo inteiro na maioria dos casos $(92,31 \%)$.

Em alguns pacientes, a mioclonia apareceu imediatamente após a picada mas teve paciente que referiu que o mesmo surgiu 10 horas após, resultando em uma média de 01 hora e 34 minutos para o surgimento.

A ataxia de marcha geralmente se manifesta em até 01 hora $(51,11 \%)$, predominantemente após decorridos 30 minutos do acidente, a média de tempo foi de 01 h e 44 minutos para iniciar os sintomas, mas em alguns casos o início foi imediato e em um outro o início ocorreu após 05 horas do acidente. 
$\mathrm{Na}$ maioria dos acidentados a dismetria iniciou em até 01 hora após o acidente, predominantemente após decorridos 30 minutos, obtendo-se a média de 1 hora e 39 minutos, podendo ocorrer de forma imediata, mas também após 05 horas do acidente.

Gráfico 12 - Distribuição das vítimas de acidentes escorpiônicos no município de RurópolisPA, segundo tempo de duração dos sintomas disartria, mioclonia, ataxia e dismetria, outubro de 2016 a setembro de 2017.

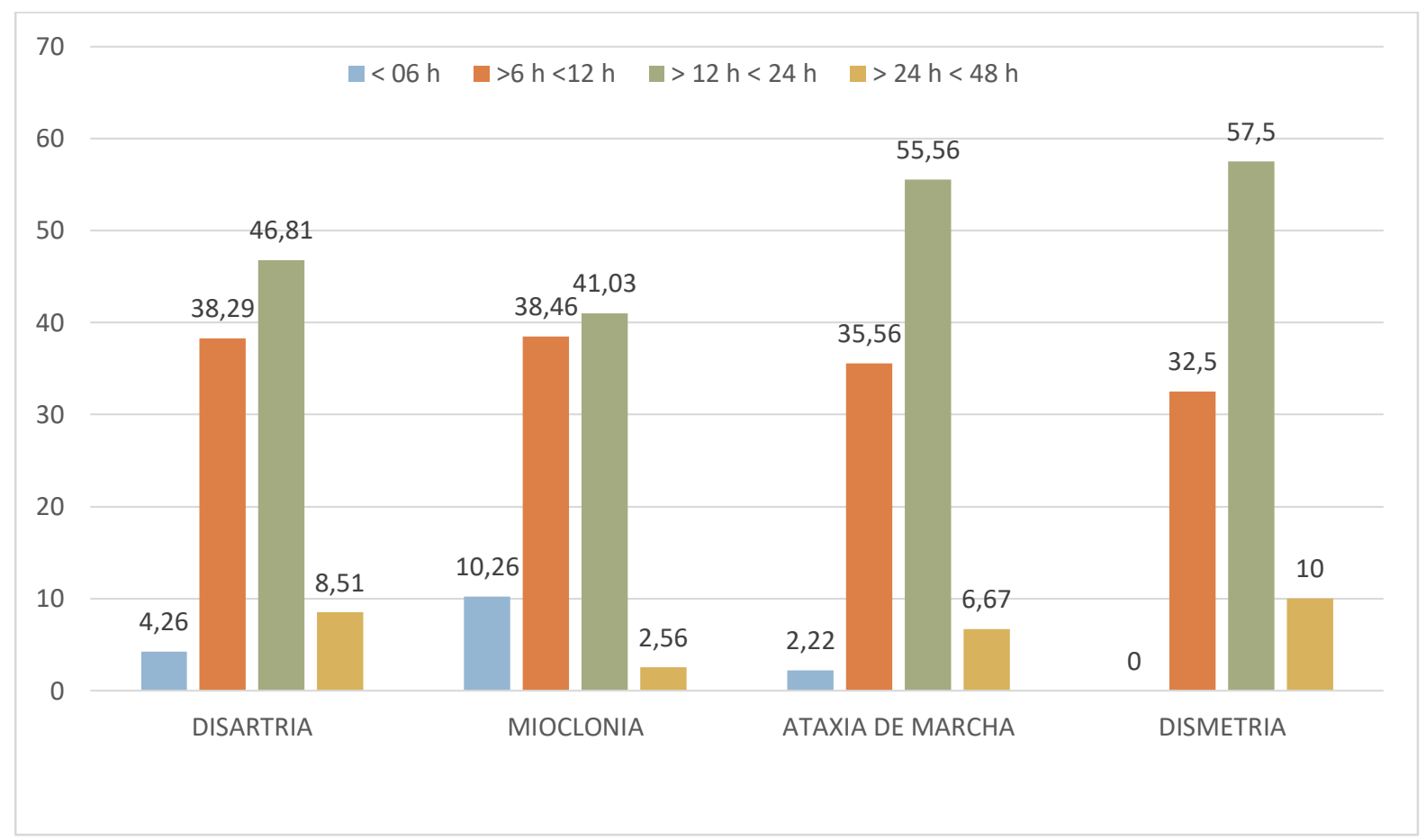

A disartria, mioclonia, ataxia de marcha e dismetria se manifestam, predominantemente, no período de 06 a 24 horas $(85,1 \%, 79,49 \%, 91,12 \%$ e $90 \%$ respectivamente).

A disartria se manifestou por, no mínimo, 04 horas e, no máximo, por 48 horas, tendo uma duração média aproximada de 16 h e 40 minutos. A mioclonia se manifestou por um período mínimo 2 horas e máximo de 48 horas, tendo uma duração média aproximada de 14 horas e 54 minutos. A ataxia de marcha se manifestou por 05 até 48 horas, com média de duração do sintoma de 16 horas e 40 minutos. A dismetria se apresentou no mínimo por 07 horas até 48 horas, com média de 18 horas e 45 minutos, acometendo simultaneamente os membros inferiores e superiores $(92,50 \%)$ e em poucos casos acometendo apenas membros superiores $(05,00 \%)$.

Os gráficos 11 e 12 mostram que o veneno escorpiônico tem a propriedade de chegar ao sistema nervoso central de forma imediata e agir sobre ele por um tempo prolongado, chegando até 48 horas de duração dos sintomas. Os quatro sintomas apresentados se manifestam 
de forma semelhante, tanto para iniciar os sintomas quanto em sua duração, que pode ser prolongada.

Outras manifestações neuromusculares também ocorreram, porém em menor frequência, como tremores $(18,80 \%)$, astenia $(15,38 \%)$, fasciculação $(07,69 \%)$, cefaleia $(03,42 \%)$, vertigem $(01,71 \%)$, hipertermia $(01,71 \%)$, paresia $(0,85 \%)$, convulsão $(0,85 \%)$ e hipotermia $(0,85 \%)$. Apesar de todas essas manifestações neurológicas, os pacientes não apresentaram rebaixamento do nível de consciência.

As manifestações cardiovasculares também foram expressivas como a hipertensão $(29,92 \%)$ e a taquipnéia $(14,53 \%)$. Outros sintomas foram bradicardia $(03,42 \%)$, taquicardia $(02,56 \%)$, arritmia $(02,56 \%)$, dispneia $(02,56 \%)$, hipotensão $(01,71 \%)$, dor torácica $(0,85 \%)$ e bradipnéia $(0,85 \%)$.

Tabela 06 - Distribuição das vítimas de acidentes escorpiônicos no município de RurópolisPA, segundo manifestações clínicas neuromusculares e cardiorrespiratórias, outubro de 2016 a setembro de 2017.

\begin{tabular}{lll}
\hline \multicolumn{1}{c}{ MANIFESTAÇÃO CLÍNICA } & $N^{\mathbf{o}} 117$ & $\%$ \\
\hline Manifestações Neuromusculares & & \\
\hline Tremores & 22 & 18,80 \\
\hline Astenia & 18 & 15,38 \\
\hline Fasciculação & 09 & 07,69 \\
\hline Cefaleia & 04 & 03,42 \\
\hline Hipertermia & 02 & 01,71 \\
\hline Vertigem & 02 & 01,71 \\
\hline Paresia de membros inferiores & 01 & 00,85 \\
\hline Convulsão & 01 & 00,85 \\
\hline Hipotermia & 01 & 00,85 \\
\hline & & \\
Manifestações Cardiorrespiratórias & & 29,92 \\
\hline Hipertensão & 35 & 14,53 \\
\hline Taquipnéia & 17 & 03,42 \\
\hline Bradicardia & 04 & 02,56 \\
\hline Taquicardia & 03 & 02,56 \\
\hline Arritmia & 03 & 02,56 \\
\hline Dispneia & 03 & 01,71 \\
\hline Hipotensão & 02 & 00,85 \\
\hline Dor torácica & 01 & 00,85 \\
\hline Bradipneia & 01 & \\
\hline
\end{tabular}


A hipertensão foi o sintoma cardiovascular com maior frequência, $(29,92 \%)$ e representa que um terço dos acidentados. O dado mais interessante é que desses 35 acidentados que manifestaram, somente 08 deles já eram hipertensos e que este sintoma se manifestou até mesmo em crianças.

O Gráfico 13 demonstra a distribuição dos níveis de pressão arterial entre todos os acidentados no período da pesquisa e, seguindo o protocolo da Sociedade Brasileira de Cardiologia (2016), esta foi dividida em hipotensão, normotensão, pré - hipertensão, hipertensão estágio I ou leve, hipertensão estágio II ou moderada e hipertensão estágio III ou grave.

Gráfico 13 - Distribuição das vítimas de acidentes escorpiônicos no município de RurópolisPA, segundo níveis pressóricos, outubro de 2016 a setembro de 2017.

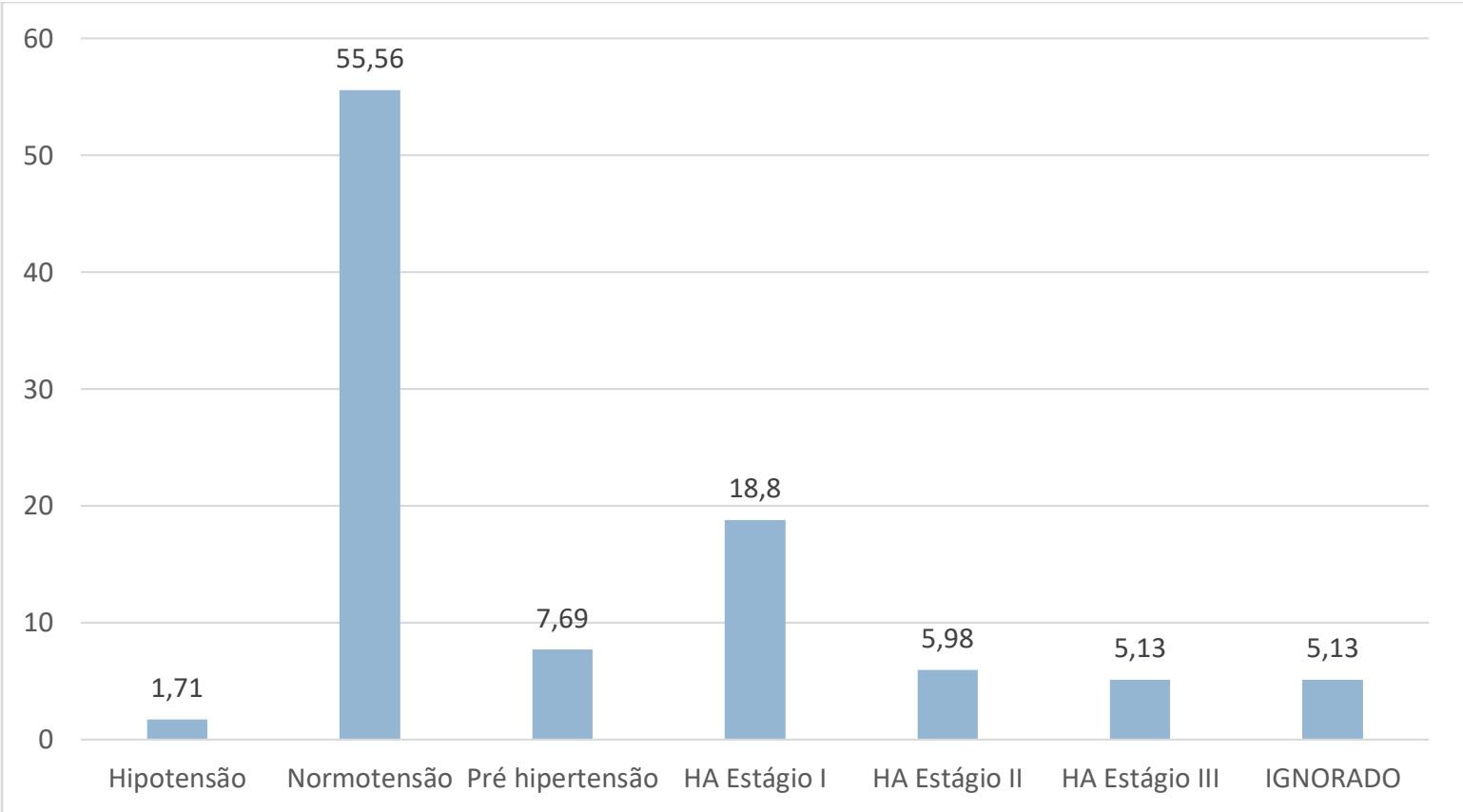

Observa-se que um pouco mais da metade dos pacientes mantiveram os níveis pressóricos dentro dos limites da normalidade $(55,56 \%)$, sendo que, entre os pacientes com alteração desse padrão, a hipertensão leve $(18,80 \%)$ foi predominante.

Entre os 117 acidentados, 10 pacientes já possuíam diagnóstico e faziam tratamento para hipertensão. Entretanto, 02 desses pacientes não manifestaram alteração dos níveis pressóricos durante a internação. 
Tabela 07 - Distribuição dos pacientes hipertensos vítimas de acidentes escorpiônicos no município de Rurópolis- PA, segundo gravidade e níveis pressóricos, outubro de 2016 a setembro de 2017.

\begin{tabular}{lccccc}
\hline & Leve & Moderado & Grave & Não classificado & Total \\
\hline Normotensão & 0 & 2 & 0 & 0 & 2 \\
HA Estágio I & 2 & 2 & 1 & 1 & 6 \\
HA Estágio II & 0 & 0 & 0 & 0 & 0 \\
HA Estágio III & 0 & 2 & 0 & 0 & 2 \\
TOTAL & 02 & 06 & 01 & 01 & 10 \\
\hline
\end{tabular}

Relacionando-se a classificação dos acidentes escorpiônicos entre os hipertensos, percebeu-se que, mesmo entre aqueles cuja pressão arterial não alterou e a classificação clínica predominante é acidente moderado, que totalizou $60 \%$ dos casos. Outros $20 \%$ foi classificado como leve, $10 \%$ grave e $10 \%$ sem classificação.

A taquipnéia ocorreu em $(14,53 \%)$ dos pacientes com sintomas sistêmicos e este sintoma pode estar relacionado com a intensidade da dor e da ansiedade diante do agravo. A arritmia $(02,56 \%)$, a taquicardia $(02,56 \%)$ e a bradicardia $(003,42 \%)$ manifestaram-se até, de certa forma, complementares pois os casos em que apresentaram variações de ritmos e frequência à ausculta cardíaca, foram submetidos à eletrocardiograma. Um dos pacientes se declarou cardiopata e ser portador de marcapasso. A bradipnéia e a hipotensão também ocorreram, porém com frequência discreta $(00,85 \%$ e $01,71 \%)$, respectivamente, diante das demais sintomatologias.

Outras manifestações clínicas também foram observadas e foram dispostas didaticamente na Tabela 08, divididas em: manifestações oftalmológicas, manifestações gastrointestinais, manifestações de pele e anexos e manifestações urinárias. 
Tabela 08 - Distribuição das vítimas de acidentes escorpiônicos no município de RurópolisPA, segundo manifestações clínicas oftalmológicas, gastrointestinais, de pele e anexos e urinárias, outubro de 2016 a setembro de 2017.

MANIFESTAÇÃO CLÍNICA
$\mathrm{N}^{\circ}$

\begin{tabular}{lll}
\hline Visão Turva & 40 & 34,19 \\
\hline Hipotonia palpebral & 18 & 15,38 \\
\hline Sensação de areia nos olhos & 04 & 03,42 \\
\hline Diplopia & 04 & 03,42 \\
\hline Pupilas anisocóricas & 03 & 02,56 \\
\hline Nistagmo & 03 & 02,56 \\
\hline Pupilas Midriáticas & 01 & 00,85
\end{tabular}

Manifestações Oftalmológicas

Manifestações Gastrointestinais

\begin{tabular}{lll}
\hline Disfagia & 32 & 27,35 \\
\hline Hipotonia/paresia da língua & 12 & 10,26 \\
\hline Náuseas & 05 & 04,27 \\
\hline Sialorréia & 03 & 02,52 \\
\hline Vômitos & 02 & 01,71 \\
\hline Polidpsia & 02 & 01,71 \\
\hline Epigastralgia & 01 & 00,85 \\
\hline Sensação de "garganta seca" & 01 & 00,85 \\
\hline Disgeusia & 01 & 00,85 \\
\hline Espasmo e edema faringeano & 01 & 00,85
\end{tabular}

Manifestações de Pele e Anexos

\begin{tabular}{llc}
\hline Piloereção & 03 & 02,56 \\
\hline Sudorese & 15 & 12,82 \\
\hline Diaforese & 01 & 00,85 \\
\hline
\end{tabular}

Manifestações Urinárias

\begin{tabular}{lll}
\hline Retenção urinária & 14 & 11,97 \\
\hline Urina concentrada & 01 & 00,85 \\
\hline Disúria & 01 & 00,85
\end{tabular}

Entre as alterações oftalmológicas, as de maior destaque nesta pesquisa foram a turvação visual $(34,19 \%)$ e a hipotonia palpebral $(15,38 \%)$. A hipotonia palpebral alguns pacientes referiram como "vista pesada" ou simplesmente alegam dificuldade de manter os olhos abertos. Outros sintomas destacam-se, não pela frequência, mas pela peculiaridade de sua ocorrência como a sensação de "ter areia nos olhos" $(03,42 \%)$, diplopia $(03,42 \%)$, anisocoria $(02,56 \%)$, nistagmo $(02,56 \%)$, midríase $(00,85 \%)$. A figura abaixo é a documentação de dois pacientes, entre os três que apresentaram anisocoria. 
Figura 14 - Pacientes apresentando pupilas anisocóricas. Legenda: a) Paciente - Caso 10; b) Olho direito (Caso 2); c) Olho esquerdo (Caso 2).

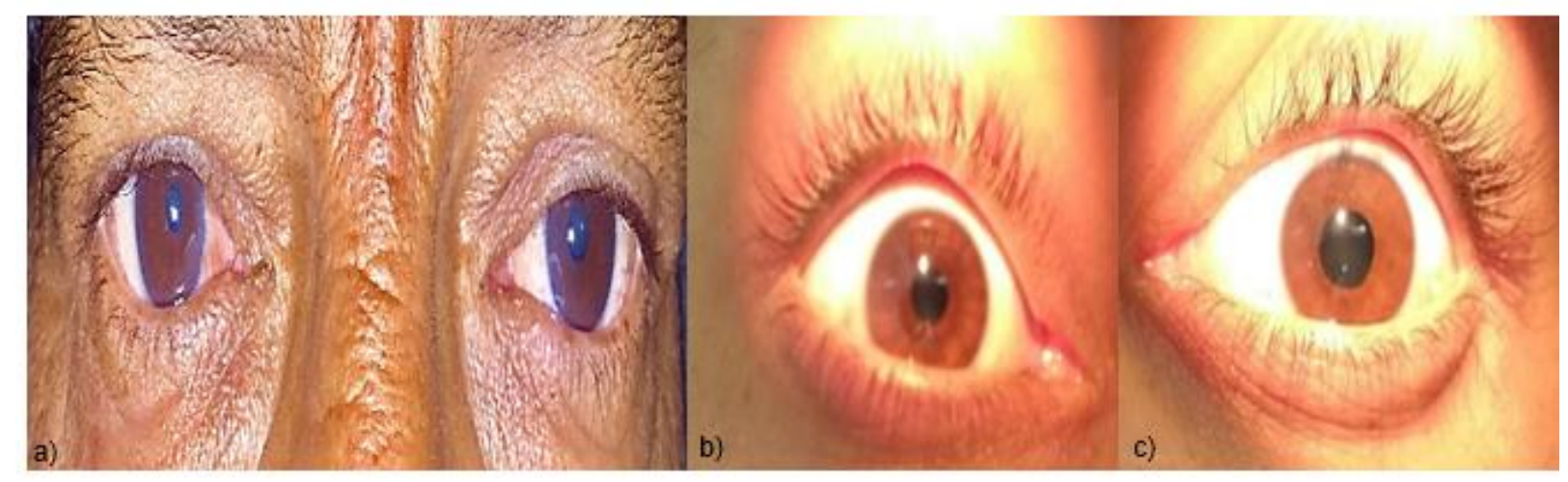

Fonte: Ana Beatriz Pedroso (2016).

Os sintomas de disfagia $(27,35 \%)$ e hipotonia/paresia da língua $(10,26 \%)$ são relatados como dificuldade de deglutir e sensação de língua pesada. De certa forma, relacionam-se aos sintomas neuromusculares, porém convencionou-se classifica-lo didaticamente como pertencente ao sistema gastrointestinal. Alguns pacientes apresentaram ainda náuseas $(04,27 \%)$, sialorréia $(02,56 \%)$, polidpsia $(01,71 \%)$, vômitos $(01,71 \%)$, epigastralgia $(00,85 \%)$, sensação de "garganta seca" $(00,85 \%)$, disgeusia $(00,85 \%)$, espasmo e edema faringeano $(00,85 \%)$. A diarreia não foi registrada nessa pesquisa.

As manifestações urinárias aconteceram em $(11,97 \%)$ dos acidentados. O principal sintoma urinário registrado nesta pesquisa foi a retenção urinária $(11,97 \%)$, que alguns pacientes referiram como "não conseguir urinar" por, no mínimo 06 horas e, no máximo, 19 horas após a picada do escorpião, tendo uma média de duração aproximada de 11 horas e 40 minutos. A "urina concentrada" e a disúria foram referidas por um paciente cada, sendo que esta última não pode ter outro diagnóstico correlacionado devido o paciente não ter realizado exame sumário de urina.

Entre as manifestações clínicas de pele e anexos, a sudorese foi a mais predominante ocorrendo e $(12,82 \%)$ dos casos. A piloereção $(02,56 \%)$ e a diaforese $(00,85 \%)$ também se apresentaram, porém em poucos casos.

Um dado importante desse estudo é a caracterização do acidente escorpiônico causado supostamente T. strandi que causa sintomatologias parecidas com os acidentes por T.obscurus. Interessa ressaltar que até o momento o mesmo não é considerado um escorpião causador de acidente de importância clínica no país, portanto exige uma caracterização dos acidentes ocasionados pelo escorpião amarelo. 
Foram 11 pacientes acidentados, em que foram picados no membro superior $(63,64 \%)$, não havendo variação muito importante entre período diurno e noturno. A maioria dos acidentes ocorreu no domicílio ou peridomicílio $(72,73 \%)$, durante a realização de tarefas cotidianas ou de lazer. Todos os pacientes apresentaram sintomas em até meia hora após a picada e $(45,45 \%)$ afirmou que o sintoma foi imediato. Em $(90,91 \%)$ dos casos apresentou sintomas locais e em $(54,55 \%)$ apresentou sintomas sistêmicos.

Tabela 09 - Distribuição dos pacientes picados por escorpião amarelo, supostamente T.strandi, no município de Rurópolis, PA, segundo manifestações clínicas, outubro de 2016 a setembro de 2017 .

\begin{tabular}{lll}
\hline \multicolumn{1}{r}{ MANIFESTAÇÃO CLÍNICA } & $\mathrm{N}^{\mathbf{0}}$ & $\%$ \\
\hline Manifestações clínicas locais & 05 & 45,45 \\
\hline Manifestações clínicas sistêmicas & 01 & 09,10 \\
\hline Manifestações clínicas locais e sistêmicas & 05 & 45,45 \\
\hline Manifestações Clínicas Locais & & \\
\hline Dor & 06 & 54,55 \\
\hline Edema & 03 & 27,27 \\
\hline Parestesia & 03 & 27,27 \\
\hline Sensação de choque elétrico & 01 & 09,10 \\
\hline Calor local & 02 & 01,71 \\
\hline & & \\
Manifestações Clínicas Sistêmicas & & 45,45 \\
\hline Dor & 05 & 45,45 \\
\hline Sensação de choque elétrico & 05 & 27,27 \\
\hline Parestesia & 03 & 27,27 \\
\hline Mioclonia & 03 & 27,27 \\
\hline Fasciculação & 03 & 18,18 \\
\hline Visão turva & 02 & 18,18 \\
\hline Dispneia & 02 & 18,18 \\
\hline Taquipnéia & 02 & 18,18 \\
\hline Cefaleia & 02 & 18,18 \\
\hline Astenia & 02 & 18,18 \\
\hline Hipertensão & 02 & 09,10 \\
\hline Sudorese & 01 & 09,10 \\
\hline Bradicardia & 01 & 09,10 \\
\hline Ataxia de Marcha & 01 & 09,10 \\
\hline Disfagia & 01 & 09,10 \\
\hline Tremores & 01 & 09,10 \\
\hline Agitação & 01 & \\
\hline & & \\
\hline
\end{tabular}

Todos os pacientes picados por escorpião amarelo sentiram dor, sendo que (90,91\%) sentiram o sintoma imediatamente e $(09,10 \%)$ sentiu até em 30 minutos. A dor foi local em $(63,54 \%)$, regional em $(18,18 \%)$ e sistêmica em $(18,18 \%)$, evoluindo em $(63,64 \%)$ dos casos 
de forma imediata e em outros $(36,36 \%)$ foi evoluindo de forma gradativa em intensidade e extensão corporal. O sintoma durou até 6 horas em $(54,55 \%)$, de 12 a 24 horas em $(27,27 \%)$ e em $(09,10 \%)$ dos casos durou até 48 horas. Em relação ao score de dor, $(36,36 \%)$ dos pacientes a classificaram como dor intensa ou máxima.

A sensação de choque elétrico foi referida por $(54,55 \%)$ dos pacientes. Em $(83,33 \%)$ dos casos, o sintoma surgiu em até meia hora e que durou de 12 a 48 horas em $(66,67 \%)$. O sintoma se manifestou de forma local em $(33,33 \%)$ e de forma sistêmica em $(66,67 \%)$ dos pacientes, acometendo o local do sintoma de forma imediata em (50\%), em intensidade e localização.

A parestesia acometeu $(54,55 \%)$ dos pacientes, iniciando em até meia hora após a picada em $(83,33 \%)$ dos casos e, em mesma proporção, durou por 12 a 48 horas. Em $(66,67 \%)$ dos pacientes o sintoma se restringiu ao local de inoculação do veneno.

A mioclonia ocorreu em (36,36\%) dos casos, iniciando em (100\%) após 30 minutos até o limite de 2 horas, com duração de até 12 horas em (50\%) dos pacientes. Em (75\%) evoluiu de forma sistêmica e gradativamente em intensidade e extensão corporal em (50\%) dos casos.

No entanto, independentemente da espécie do escorpião, a gravidade clínica dos casos foi avaliada e classificada durante a internação hospitalar, não havendo interferência dos pesquisadores. Portanto, $(45,30 \%)$ dos casos foram considerados leves, $(33,33 \%)$ moderados, $(03,42 \%)$ graves e $(17,95 \%)$ não foram classificados até o momento da alta hospitalar. Não houve letalidade no período.

Em relação aos elementos que possam atribuir gravidade, foi realizado teste $\mathrm{G}$ para relaciona-la ao tempo para o atendimento e o teste de Mann Witney para relaciona-la ao IMC, de forma a esclarecer potenciais elementos de vulnerabilidade (tabelas 10 e 11).

Tabela 10 - Distribuição das vítimas de acidentes escorpiônicos no município de RurópolisPA, segundo tempo para o atendimento e classificação clínica, outubro de 2016 a setembro de 2017.

\begin{tabular}{lccccccccc}
\hline Tempo (h) & Leve & $\%$ & Moderado & $\%$ & Grave * & $\%$ & $\begin{array}{c}\text { Não } \\
\text { Classificado }\end{array}$ & $\%$ & Valor de p \\
\hline$<1$ & 4 & 7.8 & 3 & 6.8 & 0 & 0.0 & 3 & 15.8 & 0.3983 \\
1 a 3 & 29 & 56.9 & 18 & 40.9 & 1 & 50.0 & 7 & 36.8 \\
3 a 6 & 12 & 23.5 & 17 & 38.6 & 0 & 0.0 & 7 & 36.8 \\
> 6 & 6 & 11.8 & 6 & 13.6 & 1 & 50.0 & 1 & 5.3 \\
Não informado & 0 & 0.0 & 1 & 2.3 & 0 & 0.0 & 1 & 5.3 \\
\hline Total & 51 & 100.0 & 44 & 100.0 & 2 & 100.0 & 19 & 100.0 \\
\hline \multicolumn{2}{r}{ Teste G } & & & & & & &
\end{tabular}


Na tabela 10 , verifica-se que o valor de $\mathrm{p}$ foi superior a 0,05 , revelando que neste estudo não houve associação significativa entre a classificação clínica do caso em detrimento ao tempo que o paciente levou até obter atendimento hospitalar.

Tabela 11 - Relação entre índice de massa corpórea e classificação clínica oficial dos acidentes escorpiônicos no município de Rurópolis- PA, outubro de 2016 a setembro de 2017.

\begin{tabular}{lcccc}
\hline Classificação & Freq & Mediana do IMC & IC 95\% & Valor de p \\
\hline Leve & 35 & 23.6 & 22.1 a 24.9 & 0.573 \\
Moderado & 33 & 23.9 & 22.4 a 25.0 & \\
Grave & 1 & 37.9 & - & \\
Não classificado & 14 & & & \\
\multicolumn{2}{c}{ Total } & 83 & &
\end{tabular}

Na tabela 11, verifica-se que o valor de p foi superior a 0,05 , revelando que neste estudo não houve associação significativa entre a classificação clínica do caso e a constituição corpórea do acidentado. Observa-se que a mediana do IMC foi aumentando conforme o grau de gravidade dos acidentes. Necessitando-se explorar dados além da clínica que possam indicar gravidade.

Entre esses dados a serem explorados, os exames laboratoriais demonstram mais indícios que não se apresentaram clinicamente, mas que podem repercutir em sinais de gravidade (tabela 12). 
Tabela 12 - Distribuição das vítimas de acidentes escorpiônicos no município de Rurópolis, PA, segundo exames laboratoriais, outubro de 2016 a julho de 2017.

\begin{tabular}{|c|c|c|c|c|}
\hline $\begin{array}{l}\text { EXAME } \\
\text { LABORATORIAL }\end{array}$ & $\mathrm{N}^{\mathrm{o}}$ & $\%$ & RESULTADO & $\%$ \\
\hline Glicemia & 94 & 80,34 & $\begin{array}{l}\text { Hipoglicemia }(<60 \mathrm{mg} / \mathrm{dl}) \\
\text { Normal }(60 \text { a } 110 \mathrm{mg} / \mathrm{dl}) \\
\text { Tolerância diminuída à glicose }(110 \text { a } 126 \mathrm{mg} / \mathrm{dl}) \\
\text { Hiperglicemia (> } 126 \mathrm{mg} / \mathrm{dl})\end{array}$ & $\begin{array}{l}00,00 \\
46,81 \\
22,34 \\
30,85\end{array}$ \\
\hline Colesterol & 05 & 04,27 & $\begin{array}{l}\text { Normal }(<200 \mathrm{mg} / \mathrm{dl}) \\
\text { Alterado }(>200 \mathrm{mg} / \mathrm{dl})\end{array}$ & $\begin{array}{l}100,00 \\
00,00\end{array}$ \\
\hline Triglicerídeos & 05 & 04,17 & $\begin{array}{l}\text { Normal }(<150 \mathrm{mg} / \mathrm{dl}) \\
\text { Alterado }(>150 \mathrm{mg} / \mathrm{dl})\end{array}$ & $\begin{array}{l}80,00 \\
20,00\end{array}$ \\
\hline Creatinina & 96 & 82,05 & $\begin{array}{l}\text { Normal }(<1,2 \mathrm{mg} / \mathrm{dl}) \\
\text { Alterado }(>1,2 \mathrm{mg} / \mathrm{dl})\end{array}$ & $\begin{array}{l}96,87 \\
03,13 \\
\end{array}$ \\
\hline Uréia & 96 & 82,05 & $\begin{array}{l}\text { Normal }(15-45 \mathrm{mg} / \mathrm{dl}) \\
\text { Alterado }(>45 \mathrm{mg} / \mathrm{dl})\end{array}$ & $\begin{array}{l}97,92 \\
02,08\end{array}$ \\
\hline TGO & 95 & 81,20 & $\begin{array}{l}\text { Normal (<37 U/L) } \\
\text { Alterado (> } 37 \text { U/L) }\end{array}$ & $\begin{array}{l}45,26 \\
54,74\end{array}$ \\
\hline TGP & 95 & 81,20 & $\begin{array}{l}\text { Normal }(<41 \mathrm{U} / \mathrm{L}) \\
\text { Alterado }(>41 \mathrm{U} / \mathrm{L})\end{array}$ & $\begin{array}{l}80,00 \\
20,00\end{array}$ \\
\hline Ácido Úrico & 06 & 05,13 & $\begin{array}{l}\text { Normal }(<07 \mathrm{mg} / \mathrm{dl}) \\
\text { Alterado }(>07 \mathrm{mg} / \mathrm{dl})\end{array}$ & $\begin{array}{l}100,00 \\
00,00\end{array}$ \\
\hline CPK & 72 & 61,54 & $\begin{array}{l}\text { Normal }(<175 \mathrm{mg} / \mathrm{dl}) \\
\text { Alterado }(>175 \mathrm{mg} / \mathrm{dl})\end{array}$ & $\begin{array}{l}15,28 \\
84,72\end{array}$ \\
\hline CPK MB & 57 & 48,72 & $\begin{array}{l}\text { Normal }(<05 \mathrm{mg} / \mathrm{dl}) \\
\text { Alterado }(>05 \mathrm{mg} / \mathrm{dl})\end{array}$ & $\begin{array}{l}00,00 \\
100,00\end{array}$ \\
\hline PCR & 27 & 23,08 & $\begin{array}{l}\text { Normal }(<0,8 \mathrm{mg} / \mathrm{dl}) \\
\text { Alterado }(>0,8 \mathrm{mg} / \mathrm{dl})\end{array}$ & $\begin{array}{l}92,59 \\
07,41\end{array}$ \\
\hline Plaquetas & 98 & 83,76 & $\begin{array}{l}\text { Trombocitopenia }(<150.000 / \mu \mathrm{L}) \\
\text { Normal }(150.000 \mathrm{a} 400.00 / \mu \mathrm{L}) \\
\text { Trombocitose } \quad(>150.000 / \mu \mathrm{L})\end{array}$ & $\begin{array}{l}11,22 \\
88,78 \\
00,00\end{array}$ \\
\hline \multirow[t]{3}{*}{ Hemograma } & 96 & 82,05 & $\begin{array}{l}\text { Hemácias } \\
\text { Baixa }(<4 \text { milhões/ } \mu \mathrm{L}) \\
\text { Normal }(4 \text { a } 6 \text { milhões/ } \mu \mathrm{L}) \\
\text { Alta }(>6 \text { milhões/ } \mu \mathrm{L})\end{array}$ & $\begin{array}{l}02,08 \\
93,75 \\
04,17\end{array}$ \\
\hline & & & $\begin{array}{l}\text { Hemoglobina } \\
\text { Baixa }(<12 \mathrm{~g} / \mathrm{dl}) \\
\text { Normal }(12 \text { a } 16,5 \mathrm{~g} / \mathrm{dl}) \\
\text { Alta }(>16,5 \mathrm{~g} / \mathrm{dl})\end{array}$ & $\begin{array}{l}05,21 \\
89,58 \\
05,21\end{array}$ \\
\hline & & & $\begin{array}{l}\text { Hematócrito } \\
\text { Baixo }(<37 \%) \\
\text { Normal }(37 \text { a } 50 \%)\end{array}$ & $\begin{array}{l}05,21 \\
78,13\end{array}$ \\
\hline
\end{tabular}




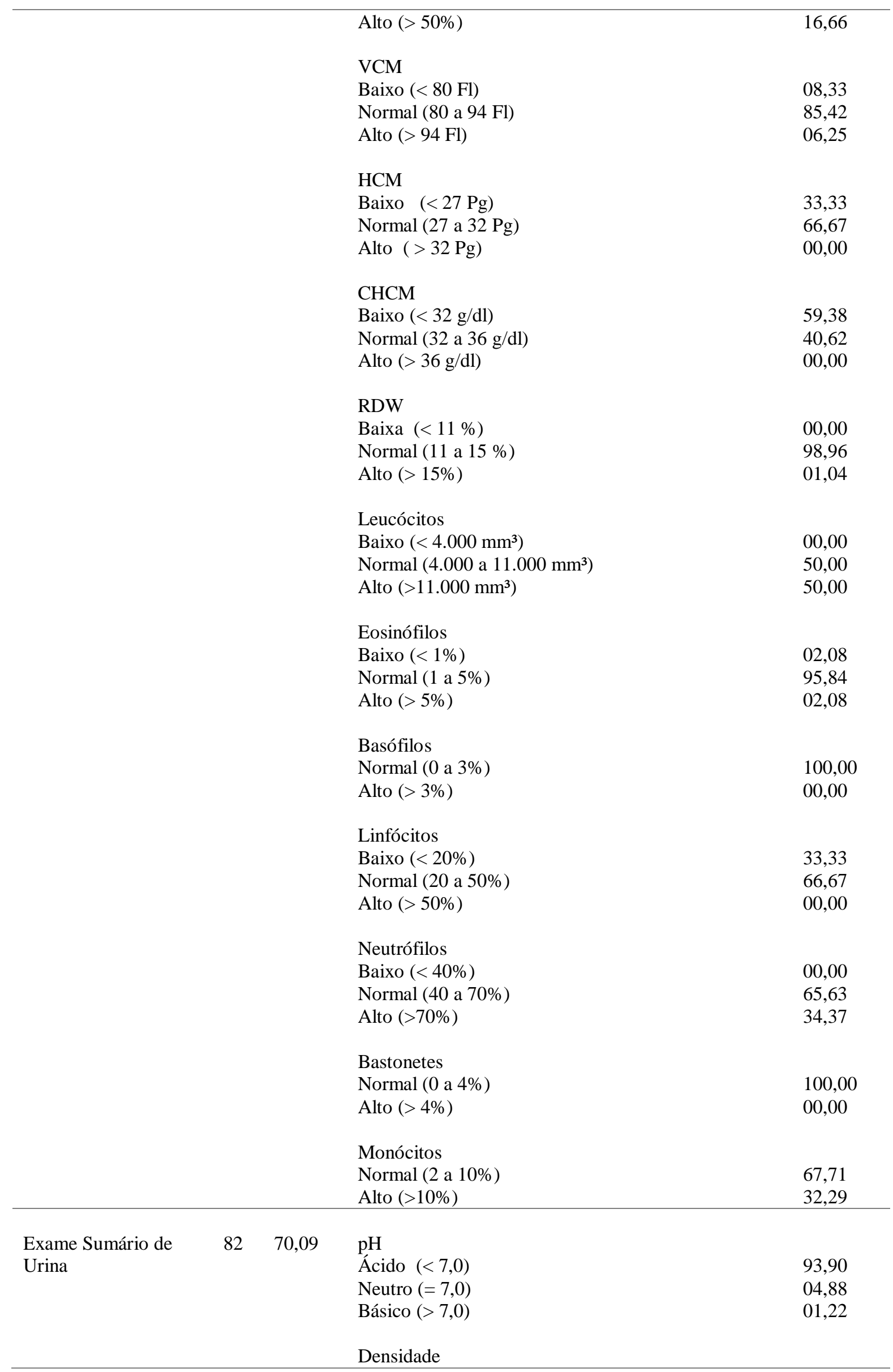




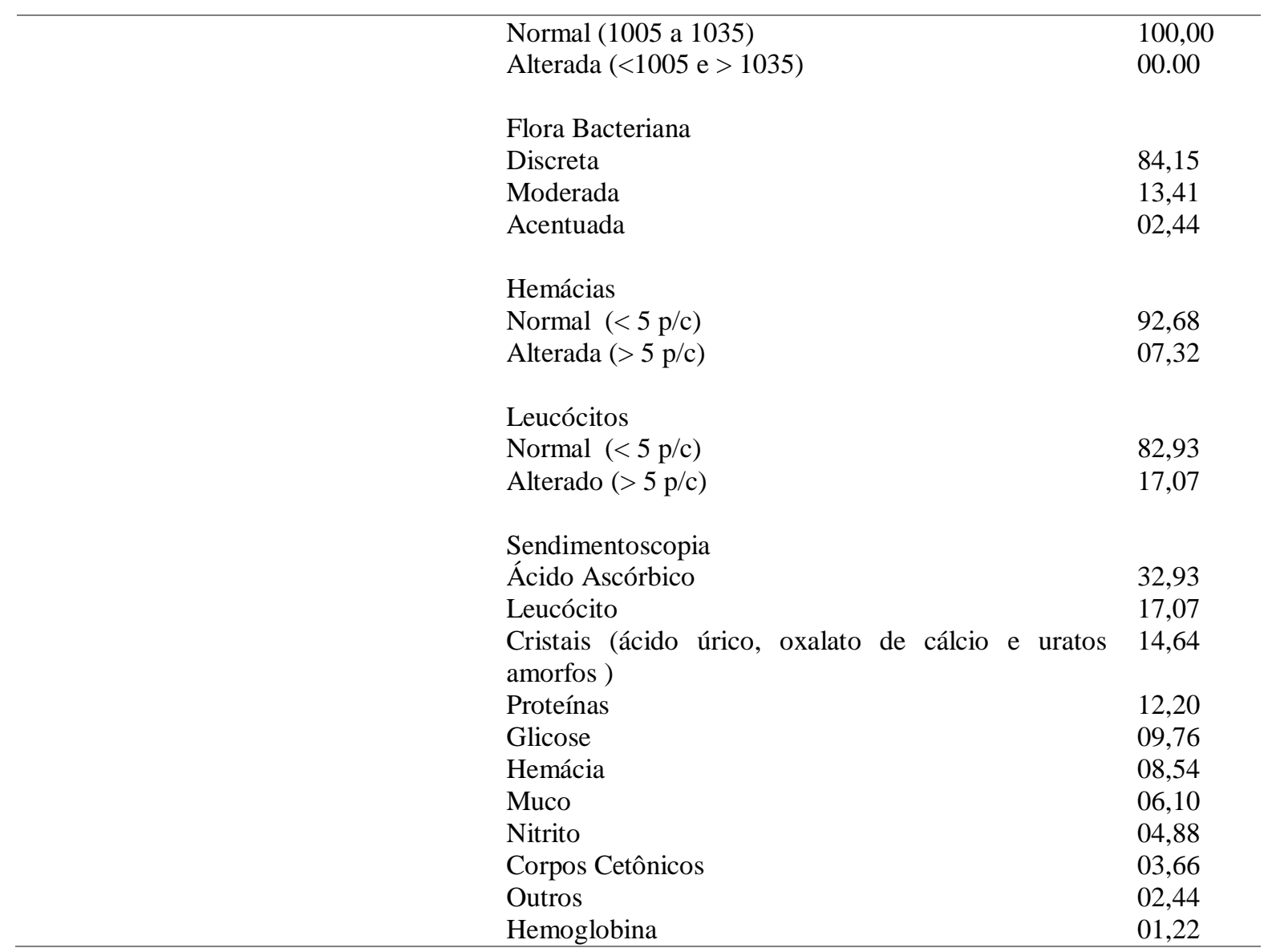

Os exames bioquímicos foram realizados em 96 pacientes e conforme a disponibilidade no serviço de saúde. Estes exames revelaram uma importante elevação dos níveis de glicemia, transaminases e de creatinoquinases.

Os valores da glicemia variaram entre 60 a 246 mg/dl, obtendo-se uma média global de $116,55 \mathrm{mg} / \mathrm{dl}$. A alteração da glicose no sangue ocorreu em $(54,95 \%)$ dos pacientes testados, sendo $(23,08 \%)$ com tolerância diminuída à glicose e $(31,87 \%)$ com hiperglicemia, a média glicêmica entre esses pacientes foi de 139,76 mg/dl. Do total de pacientes com glicemia elevada, apenas (14\%) já eram diabéticos.

Entre os 95 pacientes que realizaram exames para mensurar as transaminases, $(54,74 \%)$ e $(20 \%)$ dos pacientes testados mostraram elevados níveis de TGO e TGP, respectivamente. O nível de TGO variou de 12 a 355 U/L, com média total de 56, 87 U/L e média, entre os pacientes com níveis elevados, de 81,88 U/L. O nível de TGP variou de 10 a 123 U/L, com média total de 31,58 U/L e média, entre os pacientes alterados, de 65,47 U/L.

Os níveis de CPK foram os mais alarmantes. Entre os 72 pacientes examinados, $(84,72 \%)$ tiveram níveis elevadíssimos, chegando a uma média total de 1.459,49 mg/dl, sendo a menor taxa de 48 e chegando a taxa máxima de $17.033 \mathrm{mg} / \mathrm{dl}$ que corresponde quase 100 
vezes o valor limite de referência. Entre os pacientes com CPK alterado, a média foi de 1.705,54 $\mathrm{mg} / \mathrm{dl}$, ou seja, quase 10 vezes o valor limite de referência.

Os valores de CPK MB foram elevados em todos os 57 pacientes que foram examinados, com valor mínimo de 09 ao máximo de $401 \mathrm{mg} / \mathrm{dl}$ e com média de 53,14 mg/dl.

A creatinina e a uréia apresentaram pequenas alterações em seus valores em relação aos exames anteriores. A creatinina apresentou valor mínimo de 0,2 e máximo de 1,5 mg/dl com média global de $0,773 \mathrm{mg} / \mathrm{dl}$, sendo que apenas $(03,13 \%)$ dos pacientes apresentaram níveis séricos discretamente elevados, apresentando média de 1,366 mg/dl.

Alguns pacientes $(23,08 \%)$ coletaram amostras para PCR, obtendo-se apenas $(07,41 \%)$ de alteração. Outros exames como ácido úrico, colesterol e triglicerídeos foram realizados, porém com frequência muito pequena e com resultados que não mostraram qualquer alteração como no caso do primeiro e do segundo. No caso do triglicerídeo, um paciente apresentou nível elevado, dentro de universo de 5 examinados, mas que não poderia representar o universo dos acidentados.

Os exames hematológicos foram realizados em $(83,76 \%)$ dos pacientes, sendo constatado trombocitopenia em $(11,22 \%)$ dos casos, com níveis variando de 111.000 a $372.000 / \mu \mathrm{L}$ e média de $213.680 / \mu \mathrm{L}$.

O eritrograma revela que a quantidade de hemácias e hemoglobinas no plasma estão em concentrações normais com $(93,75 \%)$ e $(89,58 \%)$, respectivamente. Entretanto, em $(16,66 \%)$ dos pacientes identificou-se hemoconcentração, em $(4,17 \%)$ policitemia e $(5,21 \%)$ hemoglobinemia. Importa ressaltar que em $(14,58 \%)$ houve alteração do volume corpuscular médio, com $(8,33 \%)$ de microcitose e $(6,25 \%)$ de macrocitose e, quando se avalia a hemoglobina corpuscular média, observa-se $(33,33 \%)$ de hipocromia. A maioria dos pacientes apresenta baixa concentração de hemoglobina corpuscular média $(59,38 \%)$.

O leucograma revela leucocitose em (50\%) dos pacientes examinados, com neutrofilia em $(34,37 \%)$, linfopenia em $(33,33 \%)$ e monocitopenia em $(32,29 \%)$. Em (2,08\%) dos pacientes ocorreu eosinofilia, enquanto que em basófilos e bastonetes não ocorreram alterações.

A urianálise revelou que as eliminações urinárias em sua maioria são ácidas (93,90\%), ocorrendo também com pH neutro $(04,88 \%)$ e pH básico $(01,22 \%)$, todos com densidade normal e a maioria com flora bacteriana discreta (84,15\%). A sendimentoscopia revelou eliminação importante de ácido ascórbico (32,93\%), leucócitos $(17,07 \%)$ e cristais $(14,64 \%)$. Outras eliminações relevantes, não pela frequência e sim pelo significado clínico, como proteinúria $(12,20 \%)$, glicosúria $(09,76 \%)$, hematúria $(08,54 \%)$, cetonúria $(03,66 \%)$ e hemoglobinúria $(1,22 \%)$. 
O eletrocardiograma foi realizado em 60 pacientes, porém houve exclusão de 13 pelo especialista que analisou os traçados devido a impossibilidade de emitir laudo do exame. Portanto, os eletrocardiogramas de 47 pacientes foram analisados e destes $(51,06 \%)$ não apresentaram alterações em seus traçados.

Tabela 13 - Distribuição das vítimas de acidentes escorpiônicos no município de RurópolisPA, segundo eletrocardiograma, outubro de 2016 a setembro de 2017.

\begin{tabular}{llr}
\hline & ELETROCARDIOGRAMA & $\%$ \\
\hline Laudo & Distúrbios eletrofisiológicos cardíacos & 51,06 \\
\hline Normal & - & 04,26 \\
\hline Alteração de Ritmo e Frequência & Taquicardia sinusal & 08,52 \\
& & 02,13 \\
\hline Alteração de Repolarização & Alteração de repolarização anterior & 14,89 \\
& Alteração de repolarização anterosseptal & 02,13 \\
\hline Bloqueio intraventricular & Bloqueio de ramo D & 02,13 \\
& Atraso final de condução pelo ramo D & 02,13 \\
\hline Bloqueio atrioventricular & Bloqueio divisional anterossuperior & 02,13 \\
\hline Associação de Bloqueio & BAV tipo 2:1 & 02,13 \\
& Bloqueio de ramo esquerdo+ Bloqueio divisional & \\
& anterossuperior & 02,13 \\
& Atraso final de condução pelo ramo D+ bloqueio divisional & 02,13 \\
\hline Associação de Alterações & anterossuperior & 02,13 \\
\hline Área inativa & Taquicardia sinusal+ bloqueio de ramo D & 02,13 \\
\hline & Taquicardia sinusal + alteração de repolarização anterior & \\
\hline
\end{tabular}

As principais alterações eletrocardiográficas diagnosticadas foram: alteração de ritmo e frequência de onda $\mathrm{P}$, bloqueio intraventricular, alterações de repolarização e bloqueio atrioventricular. A alteração de ritmo e frequência presente foi a taquicardia sinusal $(4,26 \%)$. Os bloqueios intraventriculares presentes foram predominantemente a direita: bloqueio do ramo direito $(14,89 \%)$, bloqueio divisional anterossuperior $(2,13 \%)$ e atraso final da condução pelo ramo direito $(2,13 \%)$. As alterações de repolarização que surgiram foram a de parede anterior $(08,52 \%)$ e a anterosseptal $(2,13 \%)$.

Sendo que, em alguns casos, pacientes apresentaram dois distúrbios eletrofisiológicos simultâneos como associação de bloqueios (4,26\%), alteração de ritmo com bloqueio intraventricular $(2,13 \%)$ e alteração de ritmo com alteração de repolarização $(2,13 \%)$. Em um dos casos de associação de bloqueio ocorreu o único caso de bloqueio de ramo esquerdo associado a bloqueio divisional anterossuperior. 
Em um paciente ocorreu a extra-sístole ventricular isolada $(2,13 \%)$ e em outros foi diagnosticado área inativa $(2,13 \%)$ devido infarto do miocárdio anterior.

\subsection{Caracterização terapêutica dos acidentes escorpiônicos}

Independentemente da apresentação clínica dos acidentes escorpiônicos, o tratamento sintomático foi administrado em 116 pacientes, sendo registrada uma recusa $(0,85 \%)$ de tratamento hospitalar. A maioria dos pacientes $(81,20 \%)$ foi submetida a tratamento exclusivamente sintomático e a outra parcela $(17,95 \%)$ recebeu antiveneno específico e tratamento sintomático concomitante.

Tabela 14 - Distribuição das vítimas de acidentes escorpiônicos no município de RurópolisPA, segundo terapêutica, outubro de 2016 a julho de 2017.

\begin{tabular}{|c|c|c|c|c|}
\hline Tratamento & $\mathrm{N}^{\circ}$ & $\%$ & Discriminação & $\%$ \\
\hline Hidratação Venosa & 97 & 82,91 & $\begin{array}{l}\text { Solução Fisiológica } \\
\text { Solução Glicofisiológica } \\
\text { Solução Glicosada } \\
\text { Solução de Ringer Simples }\end{array}$ & $\begin{array}{l}62,89 \\
28,87 \\
05,15 \\
03,09\end{array}$ \\
\hline Anti-histamínico & 89 & 76,07 & $\begin{array}{l}\text { Anti-histamínico H1 } \\
\text { Anti-histamínico H2 } \\
\text { Anti-histamínicos H1 e H2 }\end{array}$ & $\begin{array}{l}19,10 \\
08,99 \\
71,91\end{array}$ \\
\hline Corticóides & 98 & 83,76 & $\begin{array}{l}01 \text { corticóide } \\
02 \text { corticóides } \\
03 \text { corticóides }\end{array}$ & $\begin{array}{l}88,77 \\
10,21 \\
01,02\end{array}$ \\
\hline Analgésicos & 107 & 91,45 & $\begin{array}{l}01 \text { analgésico } \\
02 \text { analgésicos } \\
03 \text { analgésicos }\end{array}$ & $\begin{array}{l}54,20 \\
43,93 \\
01,87\end{array}$ \\
\hline Benzodiazepínico & 56 & 47,86 & $\begin{array}{l}01 \text { benzodiazepínico } \\
02 \text { benzodiazepínicos }\end{array}$ & $\begin{array}{l}96,43 \\
03,57\end{array}$ \\
\hline Antiveneno & 21 & 17,95 & $\begin{array}{l}02 \text { ampolas } \\
03 \text { ampolas } \\
04 \text { ampolas }\end{array}$ & $\begin{array}{l}23,81 \\
28,57 \\
47,62\end{array}$ \\
\hline
\end{tabular}

No Hospital Municipal de Rurópolis há, aproximadamente, 09 anos se instituiu o cuidado de internar todas as vítimas de escorpionismo que buscarem atendimentos de emergência e administrar medicação sintomática e pré-soroterápica, se houver necessidade. Então, rotineiramente, os pacientes são notificados, submetidos a hidratação venosa $(82,91 \%)$ 
e recebem analgesia $(91,45 \%)$, sendo que alguns casos recebem ainda bloqueio anestésico no local da picada $(07,69 \%)$.

A medicação pré-antiveneno é realizada a partir de administração de corticoides e antihistamínicos com objetivo de minimizar ou bloquear efeitos alérgicos ao SAESC, porém, verificou-se nesse estudo que, na maioria dos pacientes, os medicamentos foram administrados apesar do paciente não ter recebido antiveneno específico.

Os anti-histamínicos foram administrados em (76,07\%) dos pacientes. O antagonista dos receptores H1 da histamina (prometazina) foi administrado em $(91,01 \%)$ dos pacientes, sendo que em $(19,10 \%)$ destes foi o único anti-histamínico administrado. Os antagonistas dos receptores $\mathrm{H} 2$ da histamina (cimetidina e ranitidina) foram administrados em $(80,90 \%)$ dos pacientes sendo que, em $(08,99 \%)$ dos casos, foi o único anti-histamínico administrado.

Os corticoides foram administrados em $(83,76 \%)$ dos pacientes, sendo administrado 01 $(88,77 \%)$ ou $02(10,21 \%)$ tipos de corticoides nos pacientes. Em um paciente foi administrado 3 tipos de corticoides.

A analgesia, em sua maioria, é feita com dipirona endovenosa ou diclofenaco intramuscular $(54,20 \%)$ ou com os dois medicamentos simultaneamente $(43,93 \%)$. Em 04 pacientes foi necessário administrar analgésico opióide.

Os benzodiazepínicos foram administrados em $(47,86 \%)$ dos pacientes, sendo que, em (100\%) desses receberam administração parenteral de diazepam. O outro benzodiazepínico administrado a $(03,57 \%)$ dos pacientes, em associação com diazepam, foi o clonazepam em gotas.

Os medicamentos pré-antiveneno foram realizados em única dose enquanto que analgésicos e anticonvulsivantes precisaram ser administrados outras vezes. Também foram administrados, em discreta porcentagem, anti-eméticos, anti-hipertensivos, diuréticos, entre outros.

A terapia antiveneno depende da classificação clínica do escorpionismo, porém esta classificação é um ponto controverso quando se trata de acidentes causados por T.obscurus ou T. strandi, uma vez que o conhecimento sobre suas manifestações clínicas ainda não está bem consolidado. Observa-se essa dificuldade quando simplesmente $(17,95 \%)$ dos casos não foram classificados ou quando se verifica inconsistências na indicação do antiveneno e/ou número de ampolas para classificações diversas. 
Tabela 15 - Distribuição das vítimas de acidentes escorpiônicos no município de RurópolisPA, segundo gravidade, dose de antiveneno administrada e duração dos principais sintomas neurológicos, outubro de 2016 a setembro de 2017.

\begin{tabular}{|c|c|c|c|c|c|c|c|c|c|}
\hline 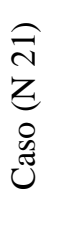 & 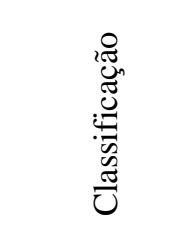 & 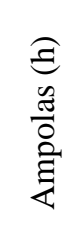 & 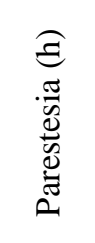 & 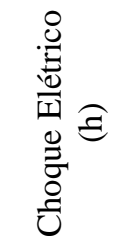 & 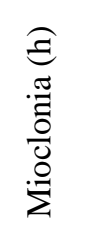 & 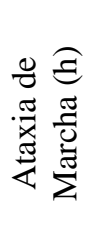 & 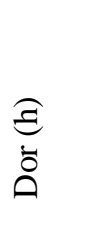 & 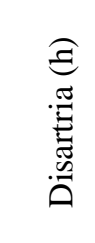 & 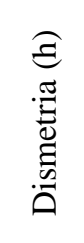 \\
\hline 6 & Leve & 3 & 15 & 15 & 2,83 & 0 & 15 & 0 & 0 \\
\hline 78 & Leve & 4 & 24 & 24 & 0 & 23 & 12 & 0 & 23 \\
\hline 84 & Leve & 4 & 11 & 14 & 24 & 0 & 12 & 14 & 0 \\
\hline 100 & Leve & 2 & 48 & 46,5 & 0 & 0 & 48 & 0 & 0 \\
\hline 1 & Moderado & 4 & 48 & 11 & 11 & 11 & 12 & 10 & 47 \\
\hline 2 & Moderado & 4 & 22 & 17 & 10 & 14 & 0 & 18 & 18 \\
\hline 4 & Moderado & 3 & 0 & 24 & 24 & 32 & 10 & 42 & 23 \\
\hline 19 & Moderado & 2 & 10 & 10 & 8 & 14 & 0 & 14 & 14 \\
\hline 26 & Moderado & 2 & 48 & 48 & 48 & 48 & 48 & 48 & 48 \\
\hline 55 & Moderado & 3 & 22 & 23 & 0 & 20 & 0,3 & 20 & 20 \\
\hline 59 & Moderado & 4 & 0 & 17 & 17 & 0 & 24 & 25 & 25 \\
\hline 67 & Moderado & 4 & 12 & 36 & 20 & 47 & 12 & 47 & 47 \\
\hline 69 & Moderado & 4 & 23 & 19 & 17 & 17 & 6 & 17 & 17 \\
\hline 73 & Moderado & 3 & 24 & 17 & 0 & 20 & 24 & 20 & 20 \\
\hline 74 & Moderado & 3 & 18 & 23 & 0 & 20 & 24 & 20 & 20 \\
\hline 77 & Moderado & 2 & 12 & 0 & 0 & 0 & 0,3 & 0 & 0 \\
\hline 97 & Moderado & 4 & 24 & 24 & 0 & 12 & 8 & 12 & 12 \\
\hline 98 & Moderado & 3 & 24,5 & 15 & 0 & 11 & 2 & 11 & 11 \\
\hline 114 & Moderado & 4 & 10 & 19 & 0 & 22 & 9 & 0 & 0 \\
\hline 9 & Grave & 4 & 12 & 11 & 14 & 14 & 12 & 7 & 16 \\
\hline 24 & $\begin{array}{c}\text { Sem } \\
\text { classificação }\end{array}$ & 2 & 16 & 24 & 24 & 24 & 0 & 24 & 24 \\
\hline & Média & 3,24 & 20,17 & 20,83 & 10,47 & 16,62 & 13,27 & 16,62 & 18,33 \\
\hline
\end{tabular}

Observa-se que apenas $(17,95 \%)$ dos pacientes receberam antiveneno de um total elegível de (36,75\%), de acordo com a classificação atribuída aos pacientes e que, apesar de receberem o antiveneno, alguns sintomas duraram até 48 horas após o acidente.

Em dois casos $(01,71 \%)$ o médico prescreveu e a unidade não dispunha de soro antiescorpiônico e este não prescreveu o soro antiaracnídico como segunda opção por receio de 
reações alérgicas. Em outros casos, apesar de haver o SAESC no hospital, não houve a prescrição médica para administração do mesmo.

Entre os 21 pacientes que receberam a antiveneno específica, $01(04,76 \%)$ apresentou reações alérgicas. A urticária foi constatada após o início da infusão de 04 ampolas de antiveneno que foi interrompida imediatamente, sendo adotados cuidados de suporte (Figura $15)$.

Figura 15 - Criança vítima de escorpionismo apresentando urticária após a administração do antiveneno, 2016.

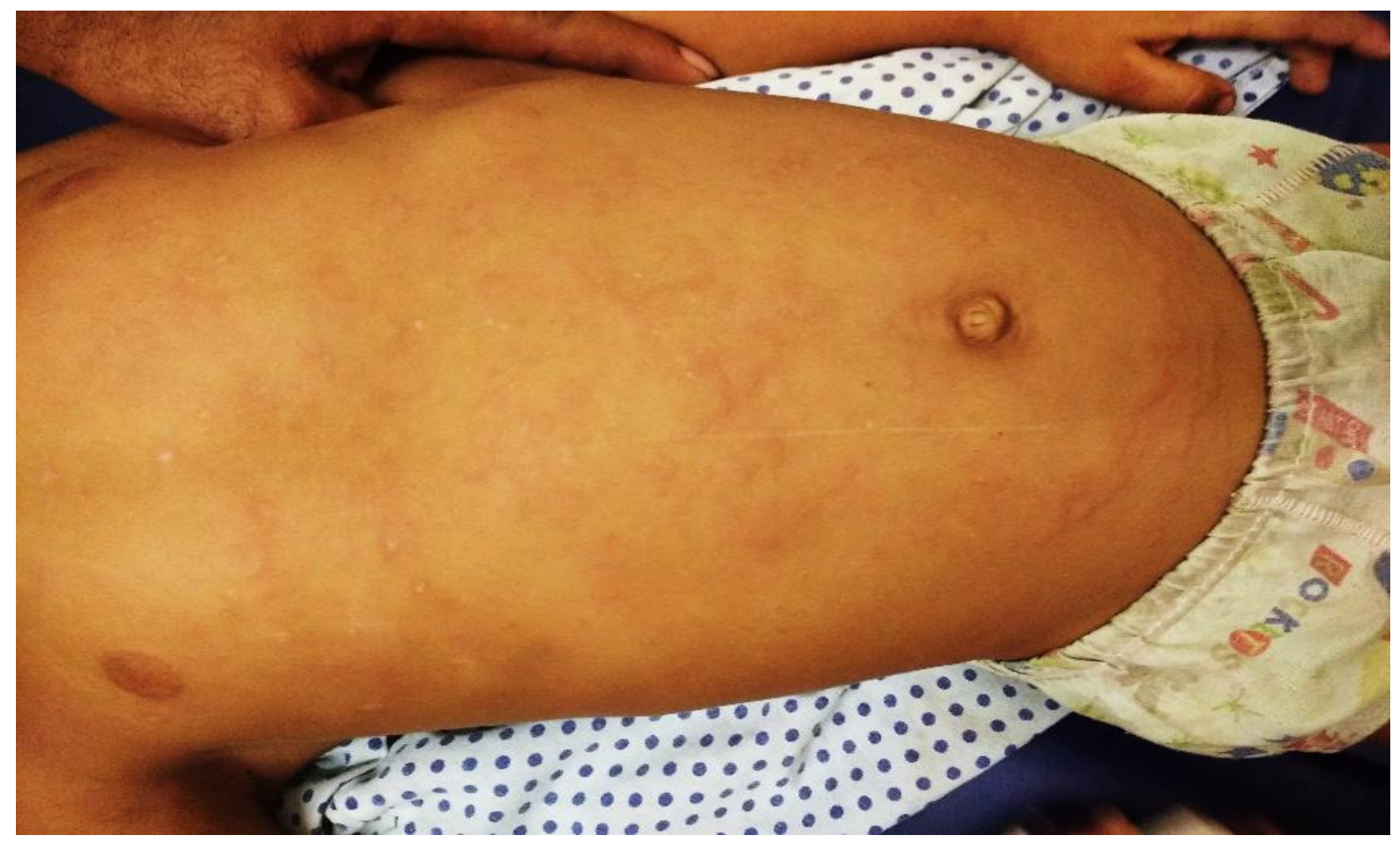

Fonte: Ana Beatriz Pedroso (2016).

Para testar a eficácia do soro antiescorpiônico no controle dos sintomas neurológicos, realizou-se teste estatístico (Mann - Whitney) com pacientes cujas manifestações sistêmicas foram monitoradas em sua duração em horas (ataxia, parestesia, choque elétrico, mioclonia, dor, disartria e dismetria), dividindo-os em dois grupos: os que receberam e os que não receberam antiveneno específica. A partir da obtenção da mediana de duração de tempo de cada sintoma, nos dois grupos, pode-se obter diversos valores de $\mathrm{p}$. 
Tabela 16 - Distribuição das vítimas de acidentes escorpiônicos no município de RurópolisPA, segundo uso ou não de antiveneno e a duração dos sintomas neurológicos, outubro de 2016 a julho de 2017.

\begin{tabular}{|c|c|c|c|}
\hline & Uso de soro & Não uso de soro & Valor de $\mathrm{p}$ \\
\hline \multicolumn{4}{|l|}{ Ataxia de marcha } \\
\hline Freq & 18 & 27 & 0.0035 \\
\hline Mediana & 20.0 & 11.0 & \\
\hline IC 95\% & $14.0-22.5$ & $10.0-15.1$ & \\
\hline \multicolumn{4}{|l|}{ Parestesia } \\
\hline Freq & 19 & 71 & 0.0106 \\
\hline Mediana & 22.0 & 12.0 & \\
\hline IC $95 \%$ & $15.4-24.0$ & $11.8-18.4$ & \\
\hline \multicolumn{4}{|l|}{ Choque elétrico } \\
\hline Freq & 20 & 69 & 0.0073 \\
\hline Mediana & 19.0 & 12.0 & \\
\hline IC 95\% & $15.5-24.0$ & $11.0-15.1$ & \\
\hline \multicolumn{4}{|l|}{ Mioclonia } \\
\hline Freq & 13 & 23 & 0.0727 \\
\hline Mediana & 17.0 & 12.0 & \\
\hline IC $95 \%$ & $10.8-24.0$ & $8.0-16.9$ & \\
\hline \multicolumn{4}{|l|}{ Dor } \\
\hline Freq & 18 & 91 & 0.4098 \\
\hline Mediana & 12.0 & 12.0 & \\
\hline IC 95\% & $10.1-20.4$ & $8.0-12.0$ & \\
\hline \multicolumn{4}{|l|}{ Disartria } \\
\hline Freq & 16 & 30 & 0.0379 \\
\hline Mediana & 19.0 & 11.0 & \\
\hline IC $95 \%$ & $13.3-24.2$ & $10.0-18.5$ & \\
\hline \multicolumn{4}{|l|}{ Dismetria } \\
\hline Freq & 16 & 25 & 0.0092 \\
\hline Mediana & 20.0 & 14.0 & \\
\hline IC 95\% & $16.8-24.2$ & $11.0-19.8$ & \\
\hline
\end{tabular}

Teste de Mann-Whitney

Observa-se que as medianas de duração dos sintomas ataxia, parestesia, choque elétrico, mioclonia, disartria e dismetria foram bem maiores no grupo de pacientes que receberam soro antiescorpiônico do que entre os pacientes que não receberam a antiveneno específica. No entanto, a mediana do sintoma dor foi exatamente igual entre os dois grupos. Esses dados sugerem que, de fato, o antiveneno disponível na rede de saúde não seja eficaz para reduzir a duração dos sintomas apresentados no acidente escorpiônico em Rurópolis, Pará.

No quadro 03 apresenta-se os casos clínicos que trouxeram o animal para confirmação da espécie causadora do acidente. 
Quadro 03 - Aspectos sociais, epidemiológicos, clínicos e terapêuticos das vítimas de acidente escorpiônico, que apresentaram o animal para identificação, atendidos no Hospital Municipal de Rurópolis, Pará, outubro de 2016 a setembro de 2017.

\begin{tabular}{|c|c|}
\hline ESCORPIÃO & DESCRIÇÃO DO CASO CLÍNICO \\
\hline T. obscurus jovem & $\begin{array}{l}\text { Caso } 03 \\
21 / 10 / 2016 \text { - } 12: 50 \mathrm{~h} \text { - C.N.N.L, } 03 \text { anos, sexo masculino, pardo, renda } \\
\text { familiar de } 01 \text { a } 02 \text { salários mínimos, mora com } 4 \text { pessoas, em casa própria } \\
\text { construída em alvenaria localizada no km } 3, \mathrm{BR} 230 \text { e BR } 163 \text {, Travessão da } \\
\text { Perdida, zona rural, Rurópolis, onde não há coleta de lixo e que chegou ao } \\
\text { Hospital após } 30 \text { minutos do acidente escorpiônico ocorrido em seu } \\
\text { domicílio. A genitora relata que o menor foi picado na nádega esquerda, no } \\
\text { momento do banho e que só chorou porque seu pai matou o animal } \\
\text { pressionando uma sandália contra a superfície da sua pele. Foi admitido no } \\
\text { HMR sem queixas, os responsáveis trouxeram apenas para observação por se } \\
\text { tratar de escorpionismo, o animal também foi trazido, porém sem } \\
\text { extremidade da cauda. } \\
\text { Exame físico: Consciente, orientado, verbalizando, couro cabeludo íntegro, } \\
\text { pupilas isocóricas, mucosas normocoradas. Tórax simétrico com boa } \\
\text { expansibilidade, murmúrios vesiculares presentes, bulhas cardíacas } \\
\text { normofonéticas, em } 2 \text { tempos, ritmo regular. Abdome plano, ruídos } \\
\text { hidroaéreos presentes, sons timpânicos à percussão. Membros e demais } \\
\text { localidades sem alterações visíveis. Sinais vitais: PA=100 x } 60 \text { mmHg; T: } \\
36,8^{\circ} \text { C; FC: } 72 \text { bpm; FR: } 15 \text { ipm. } \\
\text { Estatura: } 96 \text { cm Peso: } 22 \text { kg IMC: } 23,91 \\
\text { Observação: Sem demais avaliações pois o paciente permaneceu em } \\
\text { observação por aproximadamente } 4 \text { horas, entretanto não apresentou sintoma } \\
\text { nenhum e foi liberado para ir para a casa. } \\
\text { Classificação: Leve }\end{array}$ \\
\hline T.obscurus fêmea & $\begin{array}{l}\text { Caso } 13 \\
18 / 11 / 2016 \text { - 08:20h - L.V.P, } 32 \text { anos, sexo masculino, pardo, ensino } \\
\text { fundamental incompleto, agricultor, renda familiar de } 01 \text { a } 02 \text { salários } \\
\text { mínimos, mora com mais } 02 \text { pessoas, em casa própria construída em madeira } \\
\text { com } 2 \text { cômodos, banheiro externo com fossa em forma de "buraco negro", } \\
\text { localizada no Travessão das Águas Frias, BR } 163 \text {, zona rural, Rurópolis, onde } \\
\text { não há coleta de lixo. Foi admitido no HMR } 02 \text { horas e } 10 \text { minutos após o } \\
\text { acidente ocorrido em seu domicílio quando estava se vestindo, sendo picado } \\
\text { na coxa direita. } \\
\text { Antecedentes mórbidos pessoais: foi picado } 5 \text { vezes, sendo } 2 \text { vezes pelo } \\
\text { escorpião amarelo e } 3 \text { pelo escorpião preto, nega doenças pregressas, nega } \\
\text { tabagismo e refere etilismo. } \\
\text { Manifestações locais: edema, calor local, dor de início imediato, score } 7 \text { e } \\
\text { que durou } 30 \text { minutos. } \\
\text { Manifestações Sistêmicas: hipertensão estágio I, diaforese, náuseas, } \\
\text { fasciculação, tremores, visão turva, sensação de olhos pesados, sensação de } \\
\text { areia nos olhos, nistagmo. } \\
\text { - Sensação de choque elétrico: iniciou após } 30 \text { minutos, evoluiu de forma } \\
\text { crescente, acometeu todo corpo e durou } 20 \text { h; } \\
\text { - Parestesia: iniciou em } 30 \text { minutos, evoluiu de forma crescente, em todo } \\
\text { corpo e durou } 17 \text { h; } \\
\text { - Mioclonia: iniciou em } 30 \text { minutos, evoluiu de forma crescente, em todo } \\
\text { corpo e durou } 12 \text { h; } \\
\text { - Ataxia de marcha: iniciou após } 01 \text { h e durou } 23 \text { h; } \\
\text { - Dismetria que iniciou após } 01 \mathrm{~h} \text { e durou } 23 \text { h; } \\
\text { - Retenção urinária: durou } 12 \text { h; } \\
\text { Exame físico: Couro cabeludo íntegro, pupilas isocóricas com episódios de } \\
\text { nistagmo, mucosas normocoradas, tórax simétrico com boa expansibilidade, } \\
\text { murmúrios vesiculares presentes, bulhas cardíacas normofonéticas, em } 2\end{array}$ \\
\hline
\end{tabular}




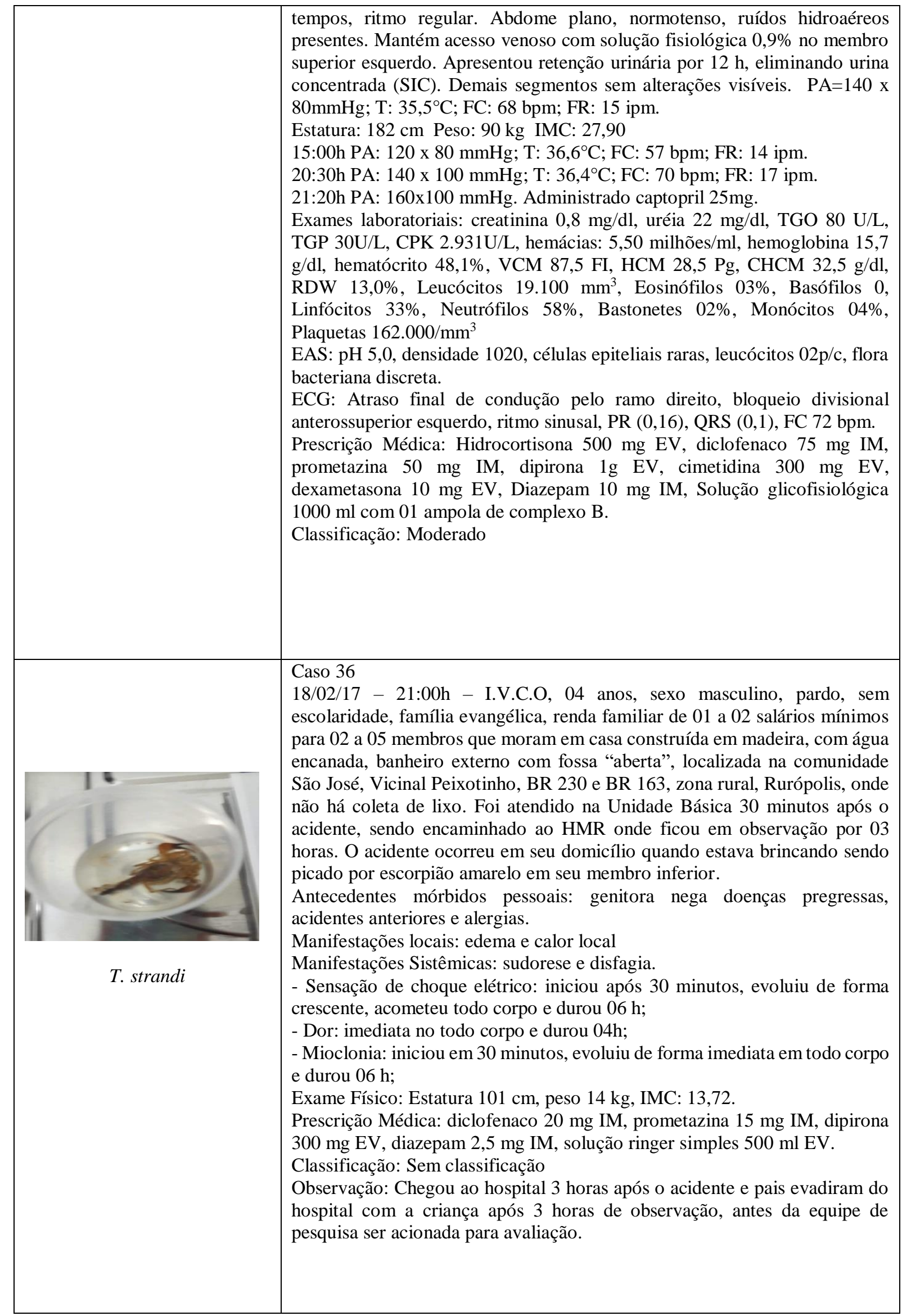




\begin{tabular}{|c|c|}
\hline T, obscurus macho & 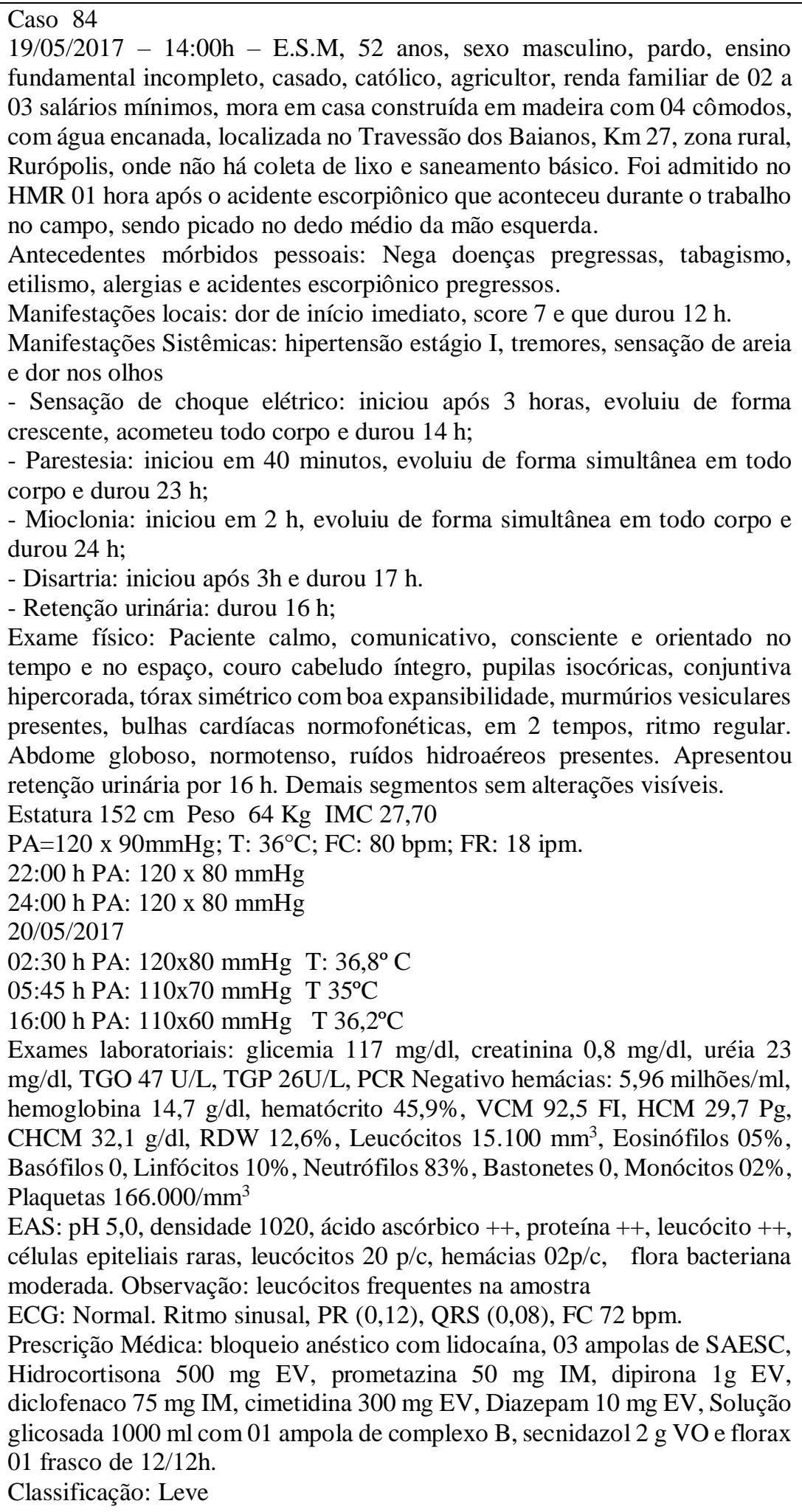 \\
\hline & $\begin{array}{l}\text { Caso } 96 \\
19 / 06 / 2017 \text { - 17:30h - M.S.S, } 3 \text { anos, sexo feminino, parda, sem } \\
\text { escolaridade, renda familiar de } 02 \text { a } 03 \text { salários mínimos, família católica } \\
\text { composta por } 02 \text { a } 05 \text { pessoas, em casa construída em madeira com } 6 \\
\text { cômodos, com água encanada, localizada na Vicinal da Eletronorte zona } \\
\text { rural, Rurópolis, onde não há coleta de lixo e saneamento básico. Foi } \\
\text { admitida no HMR } 01 \text { hora e } 30 \text { minutos após o acidente ocorrido em seu }\end{array}$ \\
\hline
\end{tabular}




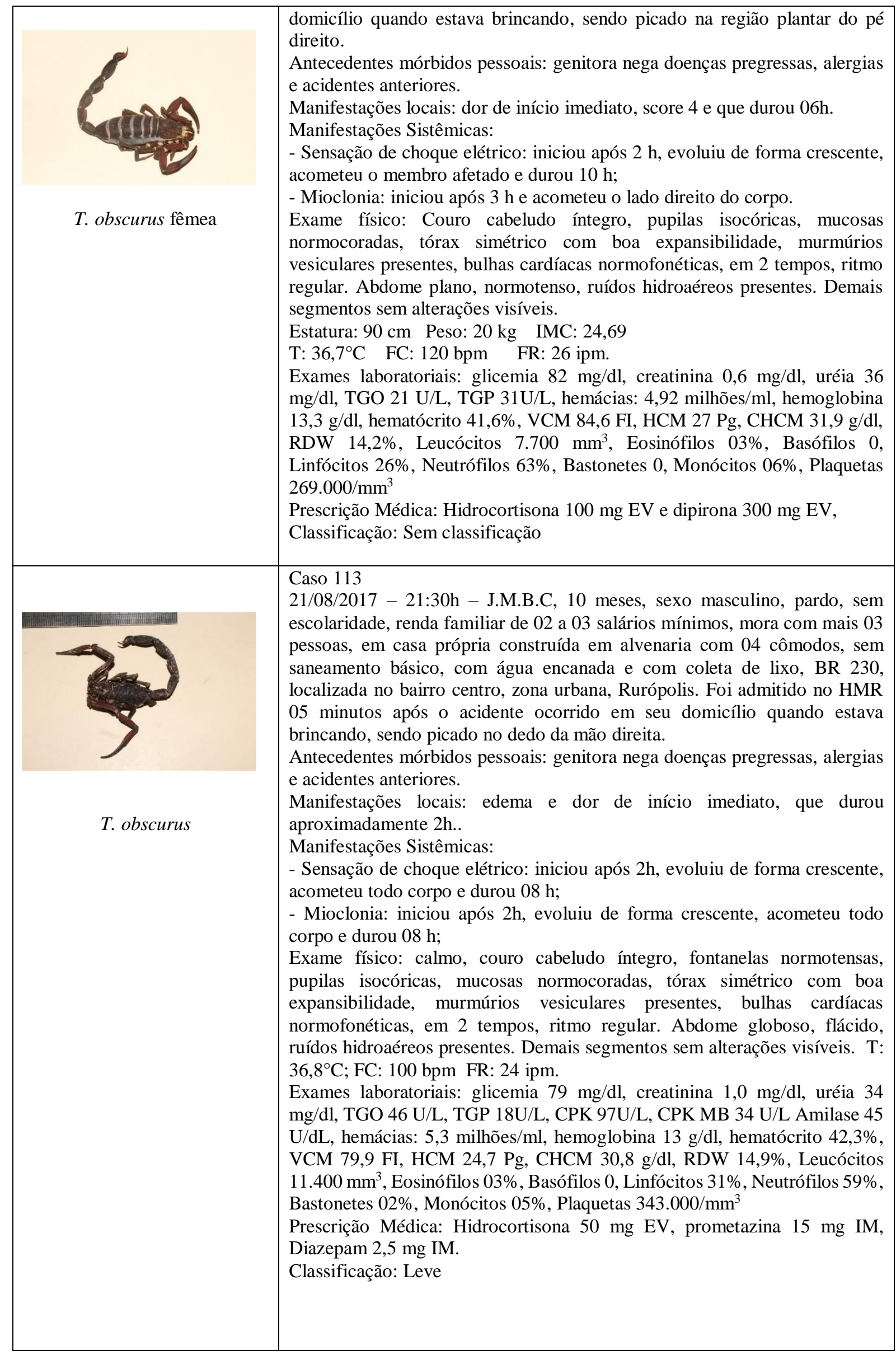


Estes foram os resultados com vítimas de acidente escorpiônico em Rurópolis, Pará, apresentados em três eixos de análise: perfil socioeconômico e de saúde, caracterização epidemiológica, caracterização clínica e terapêutica. Na sequência, segue a discussão da vulnerabilidade individual e coletiva aos acidentes escorpiônicos. 


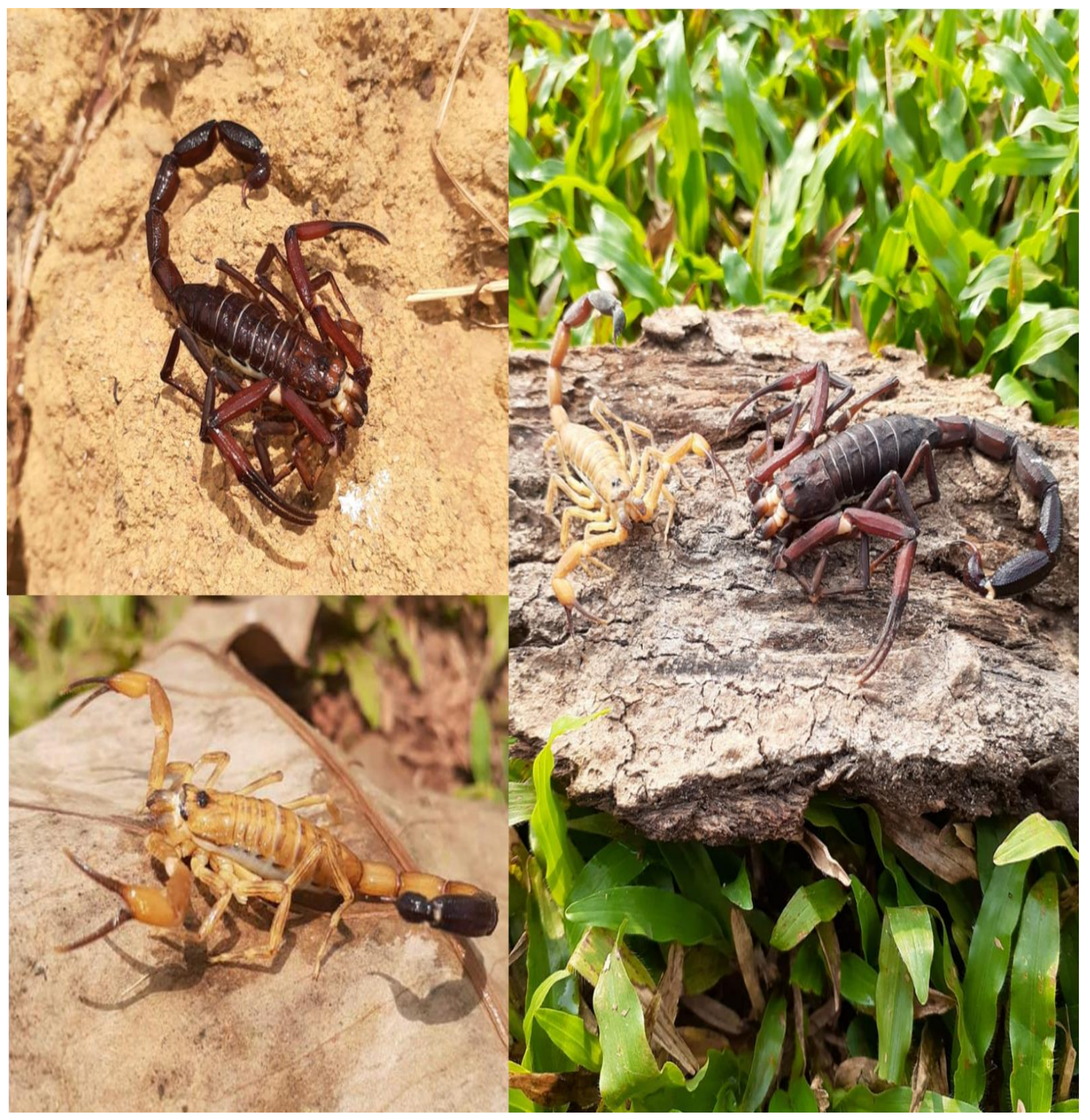




\section{VULNERABILIDADE AOS ACIDENTES ESCORPIÔNICOS}

A discussão dos dados apresentados, à luz da vulnerabilidade aos acidentes escorpiônicos, teve por referência teórica a Determinação Social do Processo Saúde e Doença e a Epidemiologia Crítica.

Breilh (2006) afirma que uma investigação epidemiológica, como no exemplo da sua pesquisa com intoxicação, deve buscar a compreensão e relacionar as três dimensões da saúde/doença: a saúde/doença diretamente evidente, a saúde/doença atual e a saúde/doença real ou realidade completa de saúde.

Neste sentido, por analogia à intoxicação, pode-se dizer que o "escorpionismo observável" é aquele que se expressa de imediato nos pacientes, aquele que se vê, como os sinais, sintomas, exames laboratoriais e gráficos. O "escorpionismo atual" engloba o primeiro e vai além, inclui todos os processos determinantes que se dão nos modos de vida típicos das coletividades e em seus estilos de vida cotidianos. O "escorpionismo real" incorpora os anteriores e inclui os processos determinantes mais amplos, inclusive processos históricos que continuam a influenciar a saúde atual. Portanto, a compreensão da doença ou do agravo perpassa pela compreensão dos contextos sociais onde o indivíduo vivencia o processo saúde/doença.

Para analisar o polo saúde, e não somente polo doença, é preciso articular os processos específicos e biológicos do acidente escorpiônico com a realidade social, econômica, cultural, política, e geoecológica da população (BREILH, 2006). Nesta perspectiva, acredita-se que condições econômicas, ambientais (de convivência ou trabalho), cultura e valores podem interferir de forma destrutiva ou protetiva na saúde das pessoas, determinando um processo de vida saudável ou de adoecimento, ou seja, o indivíduo é um ser social e histórico (DAVID; ROCHA, 2014; BREILH, 2006).

Partindo do pressuposto que, no sistema capitalista, as relações sociais de produção e reprodução da vida são permeadas por contradições que se expressam em formas desiguais de viver, adoecer e morrer, esta pesquisa analisa o acidente escorpiônico a partir da estrutura a sociedade ruropolense e como se expressam os perfis epidemiológicos.

Para tanto, o presente estudo se constituiu em um esforço para apresentar modestamente a compreensão que se teve do complexo saúde-escorpionismo como um processo multidimensional e contraditório, estruturado a partir das dimensões estrutural, particular e individual (BREILH, 2006). Essas dimensões, partindo do macro ao micro, do "escorpionismo 
real" ao "escorpionismo observável", serão apresentados a seguir, para então se construir a matriz de análise sobre os acidentes escorpiônicos na perspectiva do conceito de vulnerabilidade.

Apresenta-se a primeira dimensão da vulnerabilidade - individual e, na sequência, a coletiva, a partir das quais será apresentada a matriz de análise que compõe estas duas dimensões.

\subsection{Dimensão singular e marcadores de vulnerabilidade individual}

Considerando ainda o exemplo dos estudos de Breilh sobre intoxicações, pode-se dizer que o "escorpionismo observável" é aquele que se expressa no corpo dos pacientes, como os sinais, sintomas, exames laboratoriais e gráficos. São esses processos observáveis que se discute nesta dimensão para então compor a vulnerabilidade individual.

Durante o período pesquisado, um paciente vítima de escorpionismo não expressou qualquer manifestação clínica. Quando um animal peçonhento pica uma vítima e não inocula veneno capaz de produzir efeitos, esse evento é denominado picada seca ou dry bite. Em estudos realizados nas regiões leste e oeste do Pará, foram relatados casos de picada seca (PARDAL et al., 2014; OLIVEIRA, 2018).

Autores chamam atenção para inclusão desses casos na classificação oficial de gravidade para acidentes por animais peçonhentos adotados pelos serviços de saúde, como foi proposto em um consenso de especialistas (NAIK, 2017; KHATTABI et al., 2011).

Os sintomas iniciaram imediatamente em, aproximadamente, um terço dos casos, entretanto eles podem surgir tardiamente em até 6 horas. Este dado reforça a importância de procurar o serviço de saúde imediatamente mesmo estando ou não com algum sintoma e permaneça em observação por algumas horas. Além disso, as manifestações dependem da quantidade de veneno inoculada, do tempo de atendimento e tratamentos realizados (MAGALHÃES; PEREIRA; AMARAL, 1999; BRASIL, 2001).

Entre os pacientes, $(79,49 \%)$ apresentaram manifestações clínicas locais e $(82,91 \%)$ apresentaram manifestações clínicas sistêmicas. Estes dados aproximam-se dos resultados de um estudo realizado no Hospital Municipal de Santarém em que foram acompanhados 72 pacientes e, destes, $(91,7 \%)$ apresentaram manifestações locais e $(98,6 \%)$ apresentaram manifestações sistêmicas (PARDAL et al., 2003).

Entretanto, durante a coleta de dados, percebeu-se que alguns sintomas considerados locais como dor e parestesia, em muitas situações, ultrapassava o local da picada e acometia 
membros, hemicorpo e, até mesmo, toda extensão corporal. Da mesma forma, sintoma considerado sistêmico, como a sensação de choque elétrico, também ocorre na forma local, dado também constatado no estudo de Oliveira (2018).

Esse fato permitiu constatar que somente $(16,24 \%)$ pacientes apresentaram sintomas exclusivamente locais, $(19,66 \%)$ apresentaram sintomas exclusivamente sistêmicos e $(63,25 \%)$ apresentaram manifestações locais e sistêmicas concomitantemente. Apesar dessa divisão em sintomas locais e sistêmicos serem critérios para classificação, não foi encontrado artigo que dispusesse esses sintomas dessa forma.

As manifestações locais constatadas foram dor, parestesia, sensação de choque elétrico, edema, calor local e eritema, que também foram registrados em outros estudos (PARDAL, 2014; TORREZ et al., 2015; SILVA, 2017; OLIVEIRA, 2018). Esses três últimos sintomas podem ser resultados da ação de peptídeos NDBPs, identificados recentemente a partir da toxina de T. obscurus, e que estão envolvidos com processo inflamatório (DIAS et al., 2017).

Entre os sinais e sintomas locais, a dor foi a principal e mais frequente manifestação com $(70,09 \%)$ dos casos. Em pesquisas realizadas na América Latina com escorpiões do gênero Tityus, verificou-se que na Colômbia (95\%) e na Argentina (85\%) das pessoas picadas por escorpião referiram dor (GÓMEZ et al., 2010; DE ROODT et al., 2003).

Estudo no Piauí identificou a presença de dor em (100\%) dos acidentados e, no Pará, em dois estudos diferentes, a dor também foi o sintoma que mais aconteceu, sendo que nas cidades de Belém, Ananindeua, Santarém e Rurópolis a incidência foi de (91,6\%), enquanto que na cidade de Santarém foi (54\%) (CARVALHO, 2007; PARDAL et al., 2013; TORREZ, 2016).

Na maioria dos acidentados, a dor surgiu e evoluiu imediatamente, em intensidade e na extensão de localização, mas também foi o sintoma que desapareceu mais rapidamente, cessando em até 12 horas (em média), apesar outros casos durarem até 48 horas. Semelhante a este estudo, o acompanhamento qualitativo dos sintomas realizado no Oeste do Pará, permitiu constatar que os pacientes referiram dor imediata após a picada e que durou, em média, 11 horas (OLIVEIRA, 2018)

Apesar da dor ter sido eminentemente restrita ao local da picada, em alguns casos ela foi considerada sistêmica por acometer o membro afetado $(20,54 \%)$ ou mesmo em toda superfície corpórea $(07,14 \%)$. Ao utilizar a Escala Visual Analógica para avaliar a dor, mais da metade considerou a dor moderada, sendo o valor médio atribuído foi de 7,16. Este resultado difere dos estudos de Torrez (2016) e Silva (2017) em que a maioria dos pacientes atribuíram dor intensa. 
A dor é, indiscutivelmente, um mecanismo essencial e necessária à manutenção da vida, pois alerta que há algo acontecendo o organismo (JAMI et al., 2018). Ao citar estudos de Deuis et al (2013) e Deuis et al (2016), Jami et al (2018) afirmam que venenos de escorpião podem causar dor, pois possuem compostos que ativam seletivamente canais de sódio dependentes de voltagem (NAv1.6 e NAv 1.7) que, por sua vez, ativam a dor em diferentes modalidades.

Outras manifestações locais expressivas foram parestesia $(20,00 \%)$ e sensação de choque elétrico $(06,74 \%)$. A parestesia é relatada por estudos no Brasil e no mundo está presente nos protocolos de classificação do acidente escorpiônico estadual, nacional e internacional (PARDAL; GADELHA, 2010; BRASIL, 2001; KHATTABI et al., 2011).

A parestesia se manifestou majoritariamente como sintoma sistêmico $(80,00 \%)$ e, em mais da metade destes, surgiu em até 01 hora após a picada do escorpião. Evoluiu de forma crescente, chegando a acometer todo seguimento corporal $(60,00 \%)$. O sintoma se manifestou com tempo médio de 17 horas e 59 minutos de manifestação. No estudo de Oliveira (2018) a parestesia iniciou em até 30 minutos e durou, em média, 23 horas.

A sensação de choque elétrico foi descrita nas cidades de Rurópolis e Santarém por diversos estudos (GALVÃO; RODRIGUES, 2012; PARDAL et al., 2003; PARDAL, 2014; TORREZ et al., 2015; SILVA, 2017; OLIVEIRA, 2018). Esse sintoma também foi documentado em quatro casos de picadas de escorpião causadas por Tityus apiacas, registrados no município de Apuí, ao leste do Estado do Amazonas e que faz fronteira com o Oeste do Pará (SILVA et al., 2017)

Diferentemente da dor e semelhante à parestesia, a sensação de choque elétrico se apresenta de forma sistêmica $(93,26 \%)$ e iniciou em até 01 hora $(64,04 \%)$. No estudo de Silva (2017) surgiu em até 15 minutos em (36,8\%) dos casos enquanto Oliveira (2018) descreveu um caso em que o sintoma surgiu em 84 horas após a picada.

O sintoma evoluiu de forma crescente, acometendo todo corpo do paciente na maioria dos casos, durando entre 12 a 24 horas, com média do tempo de duração do sintoma aproximada de 16 horas. Oliveira (2018) constatou uma média de duração da sensação de choque elétrico aproximada de 20 horas, registrando caso de paciente que referiu o sintoma por 100 horas.

Fora do contexto do escorpionismo, a sensação de choque elétrico foi relatada por Siegal (1996) em seu estudo com 42 pacientes oncológicos que apresentaram após tratamento quimio ou radioterápico. O autor relata que, nesses casos, a sensação de choque elétrico poderia ser o efeito do aumento da mecanossensibilidade dos axônios centrais ou periféricos danificados da área cérvico-braquial. 
Analisando esses três sintomas, percebe-se que a dor, parestesia e sensação de choque elétrico podem ser tratados como manifestações locais ou sistêmicas. No entanto, há uma clara distinção entre o mecanismo de ação que leva à manifestação da dor e o mecanismo de ação que leva à manifestação da parestesia e da sensação de choque elétrico, que precisa ser melhor esclarecido. Apesar desses sintomas serem sensitivos, a dor manifesta-se principalmente como sintoma local, de início imediato e cessação mais precoce enquanto a parestesia e a sensação de choque elétrico são predominantemente sistêmicos, que iniciam após 30 minutos e duram em média pouco mais de 16 horas.

As manifestações sistêmicas do envenenamento do escorpião ocorrem devido a liberação de neurotransmissores em resposta às ações das toxinas nos canais de sódio, causando uma intoxicação adrenérgica ou colinérgica, o que desenvolve uma série de quadros clínicos de acordo com cada espécie de escorpião (MEKI; MOHAMED; MOHEY EL-DEEN, 2003).

Os envenenamentos por T. obscurus e T.strandi, escorpiões identificados como causadores de alguns acidentes deste estudo, apresentam sintomas sistêmicos neuromusculares, oftalmológicos, cardiorrespiratórios, gastrointestinais e urinários. Porém, a exuberância dos sintomas neuromusculares e oftalmológicos destacaram-se diante dos demais sintomas.

Os sintomas neuromusculares identificados foram a ataxia de marcha $(38,46 \%)$, disartria (40,17\%), mioclonia $(33,33 \%)$ e dismetria $(34,19 \%)$. Esses resultados são concordantes com estudos realizados no oeste do Pará (PARDAL et al., 2003; PARDAL et al., 2014; TORREZ et al., 2015; SILVA, 2017; OLIVEIRA, 2018).

A disartria surgiu em até 01 hora após o acidente, variando de imediato até o máximo de 06 horas após a picada do escorpião, com média aproximada de 01 hora e 52 minutos para se manifestar. Diferentemente, Silva (2017) demonstrou que o sintoma surgiu após 1 hora em (26,3\%) dos casos. Oliveira (2018) constatou que este iniciou em até 30 minutos, com média de tempo para o surgimento de 01hora e 37 minutos, resultado semelhante a este.

Em relação ao seu tempo de manifestação, a disartria durou cerca de 16 horas e 40 minutos, variando entre 04 a 48 horas. Este tempo foi menor ao encontrado no estudo de Oliveira (2018) que foi de aproximadamente 20 horas e 14 minutos.

A mioclonia se manifestou em até 01 hora após o acidente e os segmentos corporais vão sendo acometidos paulatinamente até atingir o corpo inteiro. Este sintoma leva, em média, 01 hora e 34 minutos para surgir e cerca de 14 horas e 54 minutos para desaparecer. Diferentemente, Oliveira (2018) registrou uma média aproximada de 02 horas e 34 minutos para seu surgimento e cerca de 23 horas e 38 minutos para desaparecer, quase o dobro de tempo nos dois quesitos. 
A ataxia de marcha geralmente se manifesta em até 01 hora com média de tempo de 01 h e 44 minutos e leva, em média, 16 horas e 40 minutos para cessar. Resultado diferente do estudo de Silva (2017) em que o sintoma surgiu mais precocemente, em até 15 minutos (31,5\%), e do estudo de Oliveira (2018) onde sintoma surgiu mais tardiamente, levando em média 3 horas e 44 minutos para se manifestar e 25 horas e 38 minutos para encerrar.

Do ponto de vista evolutivo, a dismetria iniciou em até 01 hora após o acidente com média de tempo de 1 hora e 39 minutos para iniciar e de 18 horas e 45 minutos para desaparecer. Não foram encontrados estudos que qualificassem esse sintoma, especialmente em relação ao escorpionismo.

Os quatro sintomas apresentados se manifestaram de forma semelhante, tanto para iniciar quanto em sua duração, que pode ser prolongada, reforçando a necessidade de prestar assistência de qualidade desde as primeiras horas ao paciente até o término dos sintomas.

Neste estudo, os dados confirmaram que o veneno escorpiônico ultrapassa a barreira hematoencefálica e chega ao sistema nervoso central imediatamente, podendo agir sobre o cerebelo por um tempo prolongado, chegando até 48 horas de duração dos sintomas. Essas manifestações clínicas foram caracterizadas como disfunção cerebelar aguda por Torrez et al. (2015). Esta constatação é corroborada pelo estudo de Batista et al. (2002) que conseguiu mostrar a capacidade que a toxina escorpiônica tem de afetar a permeabilidade dos canais de Sódio, íon positivo das células granulares do cerebelo de camundongos.

Um quadro aproximado do que ocorre na região foi relatado na Índia em que dois pacientes apresentaram história de início agudo de disartria, ataxia e falta de coordenação motora após picada de escorpião, compatíveis com sinais cerebelares. Após realização de tomografia computadorizada, constatou-se infartos cerebelares extensos bilaterais, o que levou os pesquisadores a concluir que os pacientes sofreram um acidente vascular cerebral trombótico causado pela ação vasculotóxica do veneno do escorpião (GADWALKAR et al., 2006).

A diferença de tempo verificada entre os estudos provavelmente deve-se ao fato de que, parte dos pacientes participantes da pesquisa de Oliveira (2018), tenha sido atendido em um Hospital de Referência, onde se espera os casos mais graves. Ao contrário dos pacientes do Hospital Municipal de Rurópolis que atende a toda demanda de acidentes, seja leve, moderado ou grave, sendo retrato mais aproximado da realidade epidemiológica de um território.

Outros sintomas neuromusculares, não menos importantes, referidos pelos pacientes foram tremores, astenia, fasciculações, hipertermia, vertigem, cefaleia, paresia de membros inferiores, hipotermia e convulsão. Outros estudos apresentam manifestações neuromusculares 
pelo mundo, como Zimbabue, Tunísia, Guiana Francesa, Estados Unidos (BERGMAN, 1996; BOUAZIZ et al., 2008; BENMOSBAH et al., 2013; BOYER et al., 2009).

A convulsão foi diagnosticada pela pediatra que assistiu o menor de 11 anos de idade, sem antecedentes mórbidos, mas que foi picado por 3 vezes pelo mesmo escorpião, uma vez que o mesmo ficou preso entre o corpo e a camisa do adolescente. Apesar de o Ministério da Saúde incluir a convulsão como um dos sintomas neurológicos que podem surgir durante o envenenamento, a sua ocorrência é rara no Brasil (BRASIL, 2001). No entanto, Ismail et al. (1990) afirmam que o comprometimento do sistema nervoso central pode ocorrer em jovens e crianças devido o estágio de desenvolvimento da barreira hematoencefálica.

Estudos experimentais mostraram que a injeção de toxinas escorpiônicas (ou frações purificadas) de algumas espécies de Tityus podem causar convulsões (LIMA et al., 1975; LOURENÇO; LEBRUN; DORCE, 2002). No entanto, a injeção de toxinas de T.obscurus em camundongos não provocou convulsões (SANTOS-DA-SILVA et al., 2017).

No México foi registrada a ocorrência de convulsões (CHOWELL et al., 2006; PETRICEVICH, 2009). Na Índia, registra-se o envolvimento do sistema nervoso devido escorpionismo em $2 \%$ a $8 \%$ dos pacientes. No entanto, vários estudos afirmam que algumas manifestações do sistema nervoso central como convulsões, ocorre devido anóxia em complicações cardiovasculares (BAWASKAR; BAWASKAR, 2012; THOMAS et al., 2017; KUMAR et al., 2014).

A turvação visual e hipotonia palpebral, referida como "vista pesada ou olho pesado", destacaram-se entre as manifestações oftalmológicas encontradas. Outros sintomas peculiares foram a sensação de ter "areia nos olhos", diplopia, anisocoria, nistagmo e midríase. Ressaltase que este estudo é o primeiro a documentar a diplopia, midríase e sensação de areia nos olhos em escorpionismo na Amazônia.

Estudos realizados no Pará registraram a ocorrência de visão turva, hiperemia conjuntival, fotofobia, nistagmo, ptose palpebral, anisocoria e ardência nos olhos (PARDAL et al., 2014; TORREZ et al., 2015; OLIVEIRA, 2018). Em outros países, como a Índia e estados Unidos, as manifestações oftalmológicas como a midríase, anisocoria, nistagmo e opsoclonus são elencadas no quadro clínico do escorpionismo (KHATTABI et al., 2011; BAWASKAR; BAWASKAR; BAWASKAR, 2017; SIMON, 2015; BOYER et al., 2009).

Estas manifestações oftalmológicas podem surgir por vários mecanismos. No caso específico, as manifestações, como nistagmo, diplopia, turvação visual podem ser resultado do acometimento cerebelar (GODEIRO JUNIOR et al., 2007; GRIMALDI; MANTO, 2011). No 
entanto, majoritariamente podem surgir como resultantes da tempestade autonômica que pode desenvolver uma irregularidade na atividade neuromuscular, podendo manifestar-se através de movimentos oculares anormais ou mesmo pelo envolvimento de pares de nervos cranianos no acidente (BOYER et al., 2009; BAWASKAR; BAWASKAR; BAWASKAR, 2017; PETRICEVICH, 2009; BENMOSBAH et al., 2013; CHOWELL et al., 2006).

Apesar da aparente singularidade das manifestações neuromusculares e oftalmológicas apresentadas no acidente causado por T.obscurus, estudos mostram que os acidentes causados pelo Centruroides sculpturatus/exilicauda, ocorridos no Arizona, Estados Unidos, também apresentam sintomas semelhantes. Segundo pesquisadores, este acidente se caracteriza, entre outros sintomas, por dor, parestesia, disfunção de nervos cranianos (visão turva, nistagmo, opsoclonus, fala arrastada, fasciculação da língua e hipersalivação) e manifestações neuromusculares (fasciculação muscular esquelética, ataxia ou perda da coordenação motora) (SIMON, 2015; BOYER et al., 2009; CHOWELL et al., 2006).

As manifestações cardiovasculares também foram expressivas como a hipertensão e a taquipnéia. Outros sintomas constatados foram: bradicardia, taquicardia, arritmia, dispneia, hipotensão, dor torácica e a bradipnéia. Estes sintomas fazem parte de consensos nacionais e internacionais (BRASIL, 2001; KHATTABI et al., 2011).

A hipertensão arterial acometeu um terço dos acidentados, inclusive criança, sendo a hipertensão leve foi predominante. Vale ressaltar que 10 pacientes já eram hipertensos, porém 02 desses mantiveram níveis pressóricos normais durante a internação. Análises proteômicas revelaram a presença de enzimas conversoras da angiotensina e da endotelina nos venenos de T. obscurus e T.serrulatus, o que explica em parte o surgimento da hipertensão e outros sintomas cardiovasculares (DE OLIVEIRA et al., 2018). Outro mecanismo de ação para esse sinal refere-se aos efeitos simpáticos/adrenérgicos das toxinas escorpiônicas (BOYER et al., 2009)

A taquipnéia, arritmia, a taquicardia, bradicardia e hipotensão foram descritas. Esses sintomas também foram constatados em outras pesquisas realizadas no Pará, porém com frequências e gravidade menores do que aqueles acidentes, de outras espécies do gênero Tityus, ocorridos no Piauí e outros estados onde a taquicardia e a hipotensão podem ocorrer em mais de (50\%) dos casos (PARDAL et al., 2003; PARDAL et al., 2013; CARVALHO et al., 2007).

Segundo Cupo (2015) esses sintomas decorrem, majoritariamente, da liberação de catecolaminas e acetilcolina. No entanto, a bradicardia e a hipotensão também podem estar relacionadas à presença de peptídeo potencializador da bradicinina que também foi identificada na análise proteômica dos venenos de T.obscurus e T.serrulatus (DE OLIVEIRA et al., 2018). 
Um registro nesta pesquisa pareceu controverso que foi o diagnóstico de edema de glote a um paciente que apresentara "falta de ar porque a garganta estava fechada", em que o médico relatou processo inflamatório na orofaringe e laringe. No entanto, relatos de espasmo e edema faríngeo (sensação de garganta fechada), perda do reflexo da faringe, sensação de nódulo na garganta ou pelo na garganta (corpo estranho), no México, encorajou a classificar o dado objetivo como espasmo de faringe (MANZANO et al., 2016; PETRICEVICH, 2009; CHOWELL et al., 2006). Importa ressaltar um caso de um paciente que necessitou de traqueostomia devido espasmo laríngeo no Zimbabue (BERGMAN, 1996).

A disfagia e a hipotonia/paresia da língua (chamada de língua pesada) foram os sintomas gastrointestinais mais referidos. Acidentes escorpinônicos do México, Estados Unidos e Zimbabue apresentam disfagia e fasciculação de língua e pesquisadores os qualifica como sintomas que acometem pares de nervos cranianos ou como sintoma parassimpático (OSNAYA-ROMERO et al., 2001; PETRICEVICH, 2009; BERGMAN, 1996). No entanto, nesse estudo, eles ainda podem estar relacionados ao comprometimento neuromuscular da disfunção cerebelar aguda.

Alguns pacientes apresentaram ainda epigastralgia, sialorréia, náuseas, vômitos polidpsia, "sensação de garganta seca", disgeusia. O único estudo encontrado, que relata este último sintoma, envolveu envenenamento por Centruroides sculpturatus em que a disgeusia se manifestou juntamente com a hiposmia, sugerindo disfunção do nervo craniano (HURST et al., 2017).

A epigastralgia, sialorréia, náuseas e vômitos são reconhecidamente sintomas colinérgicos. $\mathrm{O}$ vômito é um sintoma relatado na maioria dos acidentes escorpiônicos pelo mundo e que, se apresentar de forma incoercível, é considerado um marcador de gravidade (PETRICEVICH, 2009; BRASIL, 2001; RECKZIEGEL, 2013). Não foram encontrados estudos que relacionassem a polidpsia e a "sensação de garganta seca" com o escorpionismo.

A retenção urinária que alguns referiram como "não conseguir urinar", foi relatada inclusive com período de duração de até 19 horas após a picada do escorpião, no entanto é considerada como sintoma não ameaçador da vida, conforme consenso internacional (KHATTABI et al., 2011).

Bergman (1996) documentou o bexigoma e a dificuldade para urinar, que neste estudo foi classificado como disúria. Oliveira (2018) e Torrez et al. (2015) constataram a anúria. A oligúria foi referida por poucos pacientes e também foi descrita em estudos na região Oeste do Pará e no Zimbabue. Esses sintomas urinários são considerados colinérgicos (OLIVEIRA, 2018; BERGMAN, 1996). Não houve priaprismo. 
A sudorese, a piloereção e a diaforese também se apresentaram. A piloereção e a sudorese são resultantes da liberação de acetilcolina, portanto são sintomas parassimpáticos (MEKI et al., 2003; CUPO, 2015). No entanto, a diaforese é elencada como sintoma do sistema nervoso autônomo simpático (PETRICEVICH, 2010).

Um dado importante desse estudo é a caracterização do acidente escorpiônico causado pelo T. strandi. $\mathrm{O}$ caso aconteceu com uma criança de 04 anos, que foi picada no membro inferior em seu domicílio quando estava brincando. Apresentou edema e calor, como manifestações locais, e sudorese, disfagia, sensação de choque elétrico (que iniciou após 30 minutos, evoluiu de forma crescente, acometeu todo corpo e durou $06 \mathrm{~h}$ ), dor (imediata em todo corpo e durou 04h) e mioclonia (iniciou em 30 minutos, evoluiu de forma imediata em todo corpo e durou 06 h), como manifestações sistêmicas. Este paciente não teve classificação clínica registrada em seu prontuário ou ficha de notificação.

Esta foi a primeira documentação de acidente escorpiônico causado por T.strandi na cidade de Rurópolis. No entanto é a segunda na região oeste do Pará pois a primeira foi feita por Oliveira (2018) que registrou dois acidentes na cidade de Santarém e um acidente na cidade de Monte Alegre. Nesses, o envenenamento se apresentou com sintomas locais como dor, edema, calor, parestesia, eritema, sensação de choque elétrico. Os sintomas sistêmicos foram náuseas, tremores, espasmos, hipertensão arterial, vômitos, taquicardia, arritmia, formigamento, astenia, vertigem, ataxia de marcha, dor regional, parestesia regional e sensação de choque elétrico regional.

A dor iniciou em até 15 minutos e durou até 06 horas. Os espasmos musculares iniciaram em até 02 horas do acidente e durou por 05 horas. A parestesia iniciou em até 30 minutos e durou até 10 horas. A Sensação de choque elétrico iniciou em até 20 minutos e durou 05 horas. Um dos três pacientes apresentou mioclonia que iniciou em 20 minutos e durou até 05 horas e ataxia de marcha que iniciou em 10 minutos e durou 05 horas (OLIVEIRA, 2018).

Os dados de Oliveira (2018) revelam que o T.strandi também é um escorpião de importância clínica e que causa manifestações neuromusculares importantes, inclusive a disfunção cerebelar aguda. Entretanto, neste estudo se registra os sintomas disfagia, sudorese e o acometimento em toda extensão corporal dos sintomas dor, sensação de choque elétrico e mioclonia, que ainda não haviam sido registrados para esse tipo de escorpionismo.

Considerando-se todos os casos de acidentes provocados por escorpião amarelo, que provavelmente seria causado pelo $T$. strandi, este estudo ainda registrou como manifestações sistêmicas: visão turva, dispneia, fasciculação, cefaleia, bradicardia e agitação. 
Os exames bioquímicos revelaram uma importante elevação dos níveis de glicemia, com ocorrência em mais da metade dos pacientes e, no entanto, somente (14\%) já eram diabéticos. A hiperglicemia também foi constatada em estudos na Tunísia e no Brasil (BOUAZIZ et al., 2008; CUPO et al., 2003). Outros estudos realizados com vítimas de escorpionismo por $T$. obscurus, realizados na Guiana Francesa e Santarém, também registram a hiperglicemia (BENMOSBAH et al., 2013; TORREZ et al., 2015).

As transaminases apresentaram-se alteradas em (54,74\%) e (20\%) dos pacientes testados para TGO e TGP, respectivamente, este fato se deve à lesão de músculo esquelético como ocorreu no caso grave de acidente por T.obscurus, na cidade de Igarapé Miri, nordeste do Estado do Pará (PARDAL et al., 2014 b).

As enzimas de músculos esqueléticos tiveram resultados mais alarmantes. Os níveis de CPK, em média, foi de 1.705,54 U/L, ou seja, quase 10 vezes o valor limite de referência. Esta elevação de CPK também foi constatado nos demais estudos com T. obscurus e T. serrulatus (PARDAL et al., 2014 b; BENMOSBAH et al., 2013; TORREZ et al., 2015; CUPO et al., 2003).

Os valores de CK MB foram elevados em todos os pacientes examinados, com valor mínimo de 09 ao máximo de 401 U/L (média de 53,14 U/L). Em acidentes com $T$. serrulatus, o CK MB variou de 20 a 170 U/L (CUPO; HERING, 2002). Em estudos clínicos com vítimas de T.obscurus, Oliveira (2018) constatou nível de 28,7 U/L enquanto Pardal et al (2014b) constatou $186 \mathrm{U} / \mathrm{L}$.

A elevação de CPK entre 500 a 1000 U/L é critério diagnóstico para definir rabdomiólise, bem como sua relação proporcional aos níveis de CK MB abaixo de 5\% reforça esse diagnóstico (OKINO; FREZZA, 2018). Diante destes critérios, constatou-se que, do universo de 76 pacientes examinados, o aumento da CPK acima de $500 \mathrm{U} / \mathrm{L}$ ocorreu em $(57,89 \%)$ e que sua proporção com a CK MB, em 57 pacientes, foi inferior a $5 \%$ em $(50,88 \%)$ dos pacientes. Portanto, pode-se afirmar que a rabdomiólise ocorreu em mais da metade dos pacientes que realizaram estes exames bioquímicos.

A rabdomiólise consiste em lesão direta ou indireta aos músculos esqueléticos, que libera componentes intracelulares na circulação, como eletrólitos, mioglobina e proteínas sarcoplasmáticas (OKINO; FREEZA, 2018). No escorpionismo, essa lesão pode ser causada pela peçonha, catecolaminas e por ação de citocinas, que esteve presente em escorpionismo por T. obscurus (TEIXEIRA et al., 2001; BENMOSBAH et al., 2013; TORREZ et al., 2015; PARDAL et al, 2014 b). 
Poucos pacientes apresentaram alterações em creatinina $(3,13 \%)$ e uréia $(2,08 \%)$. Esses percentuais se aproximam do estudo de Torrez et al. (2015) em que a creatinina alterou em $(3,4 \%)$ e a uréia em $(3 \%)$, inclusive relatando caso que evoluiu com injúria renal aguda e necessitou de hemodiálise. Na Tunísia, a uréia elevada ocorreu em (10,7\%) dos casos (BOUAZIZ et al., 2008).

Os exames hematológicos revelaram trombocitopenia em 11,22\% dos casos, resultado superior ao encontrado por Benmosbah et al. (2013) que a detectou em 2\% dos casos. O eritrograma revelou $(16,66 \%)$ de hemoconcentração, $(4,17 \%)$ policitemia e $(5,21 \%)$ hemoglobinemia. No entanto, os dados mais intrigantes consistiram em importantes alterações nas hemoglobinas desses pacientes, tanto em tamanho (33,33\%) como em sua concentração no interior da hemácia $(59,38 \%)$.

O leucograma revela leucocitose em (50\%) dos pacientes examinados, com neutrofilia em $(34,37 \%)$, linfopenia em $(33,33 \%)$ e monocitopenia em $(32,29 \%)$. Vários estudos em escorpionismo por T. obscurus revelam leucocitose (ISERSON; RANCHARRAN, 2019; PARDAL et al., 2014 b; TORREZ et al., 2015). Na Tunísia, a leucocitose ocorreu em (80\%) dos acidentados e foi relacionada com mau prognóstico quando se apresenta acima de 25.000 $\mathrm{mm}^{3}$ (BOUAZIZ et al., 2008).

Outros dados intrigantes apareceram na urianálise que revelou, na sendimentoscopia, eliminação importante de ácido ascórbico (32,93\%), leucócitos (17,07\%), cristais (14,64\%), proteinúria $(12,20 \%)$, glicosúria $(09,76 \%)$, hematúria $(08,54 \%)$, cetonúria $(03,66 \%)$ e hemoglobinúria $(1,22 \%)$.

Foram encontrados poucos estudos que descrevessem a análise das eliminações urinárias. No Irã, acidentes escorpiônicos apresentam como alterações urinárias frequentes a hemoglobinúria e hematúria (VAZIRIANZADEH et al., 2012). Os resultados dessa pesquisa, chamam a atenção para sedimentoscopia da urina pois há vestígios de comprometimento clínico grave, especialmente com a constatação de hemoglobinúria, hematúria, proteinúria, glicosúria e cetonúria.

O eletrocardiograma revelou alteração nos traçados em $(48,94 \%)$ dos pacientes que realizaram o exame, sendo os bloqueios intraventriculares os mais prevalentes $(19,15 \%)$, como bloqueio do ramo direito $(14,89 \%)$, bloqueio divisional anterossuperior $(2,13 \%)$ e atraso final da condução pelo ramo direito $(2,13 \%)$. O bloqueio atrioventricular é descrito como uma manifestação do escorpionismo no Brasil (BRASIL, 2001).

As alterações de repolarização que surgiram foram a de parede anterior e a anterosseptal. A alteração de ritmo e frequência presente foi a taquicardia sinusal e alguns pacientes 
apresentaram dois distúrbios eletrofisiológicos simultâneos como associação de bloqueios, alteração de ritmo com bloqueio intraventricular e alteração de ritmo com alteração de repolarização. Em um paciente ocorreu a extra-sístole ventricular.

Cupo et al., (2003) afirma que os achados eletrocardiográficos do escorpionismo se assemelham aos de um infarto agudo do miocárdio. Entre outros achados, os autores descrevem a ocorrência de alterações que foram constatadas nesta pesquisa, como a taquicardia sinusal, extra-sístole ventricular, distúrbios de repolarização. No estado do Amazonas, Souza et al., (1995) relatou um caso grave de uma criança vítima de escorpionismo por T. metuendus em que foi constatado uma isquemia subepicárdica na parede anterosseptal.

Na dimensão individual, a vulnerabilidade se expressa a partir do grau e qualidade de informações sobre os problemas de saúde, da forma como ela é processada e aplicada na prática, através do comportamento pessoal (AYRES et al., 2009; MUÑOZ-SANCHEZ; BERTOLOZZI, 2009).

O quadro de vulnerabilidade aos acidentes escorpiônicos foi elaborada a partir de dados objetivos relacionados aos casos, que permitiram detectar potenciais marcadores que compõem as dimensões individuais e coletivas. 
Quadro 04 - Marcadores de vulnerabilidade individual identificados nos dados obtidos das vítimas de acidente escorpiônico em Rurópolis, Pará.

\begin{tabular}{|c|c|c|}
\hline \multicolumn{3}{|c|}{ CATEGORIAS DEFINIDORAS DE VULNERABILIDADE INDIVIDUAL } \\
\hline Eixos norteadores & Marcadores & Dados objetivos \\
\hline $\begin{array}{l}\text { Modos de produção e } \\
\text { reprodução social }\end{array}$ & $\begin{array}{l}\text { - Homens, jovens, faixa etária economicamente } \\
\text { ativa (21-40 anos) foi mais vulnerável para o } \\
\text { escorpionismo e o agravamento do quadro } \\
\text { - Crianças e adolescentes que vivem em áreas } \\
\text { rurais } \\
\text { - Trabalhadores e moradores de áreas rurais } \\
\text { (habitat natural do escorpião) } \\
\text { - Localidades sem infraestrutura sanitária } \\
\text { - Vítimas do acidente em plena execução de seu } \\
\text { trabalho ou tarefas cotidianas domiciliares } \\
\text { - A não disponibilidade de Equipamentos de } \\
\text { Proteção Individual, em especial para membros } \\
\text { superiores, envolvendo processo produtivo da } \\
\text { região } \\
\text { - Localidades com rede de transporte } \\
\text { rodoviário precária. }\end{array}$ & $\begin{array}{l}\text { - 75,20\% em homens } \\
\text { - 38,45\% 21-40 anos } \\
\text { - } 84,62 \% \text { população negra (pardos e } \\
\text { negros) } \\
\text { - 49,57\% agricultores } \\
\text { - 64,10\% renda familiar entre } 2 \text { a } 3 \\
\text { salários mínimos } \\
\text { - 68,37\% com ensino fundamental } \\
\text { incompleto } \\
\text { - } 58,13 \% \text { acidentes envolvendo } \\
\text { membros superiores } \\
\text { - 31,62\% dos acidentes ocorreram em } \\
\text { domicílios rurais } \\
\text { - 63,25\% localidades sem coleta de } \\
\text { resíduos (maioria rural) } \\
\text { - 100,00\% do município não possui } \\
\text { rede de esgoto (maioria fossa negra) } \\
\text { - Trabalhadores em cultivo de banana, } \\
\text { cacau e sementes (pimenta e urucum), } \\
\text { muitos agricultores familiares, com } \\
\text { participação de todos os membros, } \\
\text { inclusive crianças } \\
\text { - Dificuldade de acesso aos serviços } \\
\text { essenciais (saúde, educação, cartórios } \\
\text { etc). }\end{array}$ \\
\hline $\begin{array}{l}\text { Grau e qualidade da } \\
\text { informação que os } \\
\text { indivíduos, famílias e } \\
\text { grupos possuem } \\
\text { sobre o escorpião e } \\
\text { sobre o acidente em } \\
\text { si e formas de } \\
\text { prevenção }\end{array}$ & $\begin{array}{l}\text { - Como o acidente por animal peçonhento faz } \\
\text { parte do cenário em que habitam, os saberes e } \\
\text { as práticas no manejo do acidentado } \\
\text { representam o repasse de conhecimento } \\
\text { tradicionalmente apreendidos do senso } \\
\text { comum. } \\
\text { - Pouca informação de qualidade sobre } \\
\text { prevenção } \\
\text { - Participação da população em grupos } \\
\text { associativos é condicionada para benefícios } \\
\text { financeiros, porém pouco utilizada para } \\
\text { fortalecimento de grupo social. }\end{array}$ & $\begin{array}{l}\text { - 40,17\% já havia sido picado por } \\
\text { escorpião. } \\
\text { - } 26,06 \% \text { conhece e aplica } \\
\text { algumas práticas de cuidado em } \\
\text { casos de envenenamento antes de } \\
\text { chegar a Unidade de Saúde } \\
\text { - } 12 \text { bairros e somente } 02 \text { possuem } \\
\text { associação de moradores ativa. }\end{array}$ \\
\hline $\begin{array}{l}\text { Existência ou não de } \\
\text { pré-condições para } \\
\text { diminuir a } \\
\text { vulnerabilidade (ex.: } \\
\text { valores, crenças e } \\
\text { representações sobre } \\
\text { as escorpião e sobre o } \\
\text { acidente); }\end{array}$ & $\begin{array}{l}\text { Pré-condições que não diminuem a } \\
\text { vulnerabilidade. } \\
\text { - Existem pessoas que creem em benefícios } \\
\text { dos procedimentos realizados antes do } \\
\text { atendimento em saúde como aplicar } \\
\text { torniquete, colocar substâncias sobre o local } \\
\text { da picada e ingerir soluções com efeitos } \\
\text { duvidosos. } \\
\text { - Experiência cotidiana com os acidentes } \\
\text { escorpiônicos de ocorrência recorrente, de } \\
\text { baixa gravidade e letalidade, faz com haja } \\
\text { "naturalização do fenômeno". }\end{array}$ & $\begin{array}{l}\text { - 40,17\% com história prévia de } \\
\text { acidente por escorpião } \\
\text { - 26,06\% uso de práticas de cuidado } \\
\text { em casos de envenenamento antes de } \\
\text { chegar a Unidade de Saúde: ingestão } \\
\text { de alguma solução/suspensão; uso de } \\
\text { alguma substância no local da picada; } \\
\text { uso do torniquete; } \\
\text { - Dos que sofreram acidente } \\
\text { anteriormente, } 57,45 \% \text { afirmaram ter } \\
\text { sido assintomáticos e, dos } \\
\text { sintomáticos, as manifestações foram } \\
\text { do quadro clínico leve (dor, parestesia, } \\
\text { choque elétrico) }\end{array}$ \\
\hline
\end{tabular}




\begin{tabular}{|c|c|c|}
\hline & $\begin{array}{l}\text { Pré-condição que pode reduzir a } \\
\text { vulnerabilidade. } \\
\text { - O reconhecimento do animal pelo próprio } \\
\text { nome; } \\
\text { - Não aplicação de práticas inadequadas antes } \\
\text { da chegada ao hospital } \\
\text { - Há o reconhecimento quanto a necessidade } \\
\text { de ida ao serviço de saúde. }\end{array}$ & $\begin{array}{l}\text { - } 100 \% \text { reconheceram o animal como } \\
\text { escorpião. } \\
\text { - A maioria dos acidentados } 70,94 \% \\
\text { afirmou que não realizou cuidados } \\
\text { antes da chegada ao hospital. } \\
\text { - No período, foram } 119 \text { pacientes e } \\
\text { apenas } 2 \text { não procuraram o serviço de } \\
\text { saúde }\end{array}$ \\
\hline $\begin{array}{l}\text { Condição de } \\
\text { imunidade } \\
\text { Presença de doenças } \\
\text { pregressas } \\
\text { (cardiovasculares, } \\
\text { renais, neurológicas, } \\
\text { doenças } \\
\text { imunodepressoras, } \\
\text { medicamentos } \\
\text { imunossupressores, } \\
\text { etc) }\end{array}$ & $\begin{array}{l}\text { Pré-condições que diminuem a } \\
\text { vulnerabilidade. } \\
\text { - Estilo de vida saudável: em sua maioria, } \\
\text { pessoas com peso adequado à sua estatura, } \\
\text { que negam consumir álcool ou tabaco, negam } \\
\text { possuir alergias de qualquer natureza e não } \\
\text { possuem antecedentes mórbidos } \\
\text { Pré-condição que não reduzem a } \\
\text { vulnerabilidade. } \\
\text { - A Hipertensão Arterial Sistêmica- HAS e } \\
\text { Diabetes Melitus - DM foram as condições } \\
\text { mórbidas que mais representaram } \\
\text { suscetibilidade ao agravamento do quadro } \\
\text { clínico, tanto pela elevação da pressão arterial, } \\
\text { pelas alterações de ritmo, de frequência } \\
\text { cardíacas e do eletrocardiograma, mas } \\
\text { também pela elevação da glicemia e } \\
\text { eliminação da glicose na urina. }\end{array}$ & $\begin{array}{l}\text { - 33,33\% acidentados possuíam peso } \\
\text { adequado à sua estatura } \\
\text { - 68,36\% negam etilismo } \\
\text { - 78,64\% negam tabagismo } \\
\text { - 70,95\% negam antecedentes } \\
\text { mórbidos } \\
\\
\text { - 29,92\% evoluiu com hipertensão } \\
\text { - A hipertensão acometeu até crianças } \\
\text { - Dos 35 pacientes, } 10 \text { já eram } \\
\text { hipertensos. } \\
\text { - Alterações importantes no ECG } \\
\text { - Exames revelaram hiperglicemia e } \\
\text { glicosúria. }\end{array}$ \\
\hline $\begin{array}{l}\text { Suscetibilidade } \\
\text { relacionada à fatores } \\
\text { de risco como: } \\
\text { obesidade, } \\
\text { desnutrição, } \\
\text { tabagismo, entre } \\
\text { outros. }\end{array}$ & $\begin{array}{l}\text { - Pessoas com peso adequado e com sobrepeso } \\
\text { foram mais vulneráveis ao agravamento. }\end{array}$ & $\begin{array}{l}\text { - O único caso grave acometeu } \\
\text { homem, } 34 \text { anos com obesidade grau } \\
\text { II. } \\
\text { - Dos } 33 \text { casos moderados, } 15 \\
\text { ocorreram em indivíduos com IMC } \\
\text { adequado e } 13 \text { com IMC para } \\
\text { sobrepeso. }\end{array}$ \\
\hline $\begin{array}{l}\text { Condições clínicas } \\
\text { que impõe } \\
\text { vulnerabilidades }\end{array}$ & $\begin{array}{l}\text { Disfunção cerebelar aguda incapacita } \\
\text { temporariamente o indivíduo a realizar o } \\
\text { autocuidado, deambular, alimentar-se, } \\
\text { comunicar-se e limita a acuidade visual. } \\
\text { Expondo-o a lesões por quedas, suporte } \\
\text { nutricional aquém do necessário e dificuldades } \\
\text { na comunicação verbal. } \\
\text { O veneno causa liberação de citocinas, } \\
\text { rabdomiólise e a eliminação de proteínas, } \\
\text { glicose, entre outras substâncias podem levar à } \\
\text { injúria renal. }\end{array}$ & $\begin{array}{l}\text { Ataxia de marcha } \\
\text { Dismetria } \\
\text { Disartria } \\
\text { Disfagia } \\
\text { Turvação visual } \\
\text { Diplopia } \\
\text { Nistagmo } \\
\text { Mioclonia } \\
\text { Fasciculações } \\
\text { Astenia } \\
\text { CPK alterada } \\
\text { CK MB alterada } \\
\text { Proteinúria } \\
\text { Glicosúria } \\
\text { Cetonúria } \\
\text { Ureia alterada } \\
\text { Creatinina alterada }\end{array}$ \\
\hline
\end{tabular}


5.2 Dimensões particular e estrututal e marcadores de vulnerabilidade coletiva (programático e social)

$\mathrm{Na}$ dimensão particular, buscou-se conhecer os modos de vida típicos ou modos peculiares à cidade de Rurópolis, sua história, seus grupos sociais, como se formaram, sua cultura, seus saberes, suas práticas e como se relacionam com o ecossistema. Também se buscou a compreensão de como vivem, o que produzem, como trabalham, qual a situação econômica, seus específicos modos de trabalho, os processos geradores e mediadores que conferem exposição ou proteção (fortalecimento ou desgaste) bem como seus contextos de vulnerabilidade das mais distintas ordens.

Rurópolis é um município considerado rural remoto, situado na região oeste do Pará e estrategicamente localizado no encontro das rodovias Santarém-Cuiabá e Transamazônica. Seu território foi se constituindo na década de 70 a partir da abertura dessas rodovias, através do Programa de Integração Nacional do Governo Federal durante a ditadura militar (IBGE, 2017). Esta abertura se deu através de intenso processo de desmatamento da floresta amazônica e à custa de vidas silvestres e humanas, a partir da mudança de hábitat da fauna e da flora e do contato com agentes etiológicos que ceifavam a vida dos trabalhadores que "abriram" estrada.

Com os slogans "integrar para não entregar" e "terras sem homens para homens sem terra”, o governo atraiu para região populações migrantes oriundas de todos os Estados da federação, especialmente nordestinos e sulistas. Essas populações chegaram à região com a promessa de reforma agrária e assentamento ao longo das rodovias, que contariam com núcleos "urbanos" denominados Agrovilas, Agrópolis e Rurópolis que lhes proporcionariam uma infraestrutura básica.

As agrovilas eram conjuntos de lotes com casas instaladas no espaço de 100 hectares que tinham 1 escola de ensino fundamental (primeiro grau à época), 1 igreja ecumênica e 1 posto médico. As agrópolis eram um conjunto de agrovilas e que dispunham de serviços bancários, correios, telefônicos e escolas de ensino médio (segundo grau). As Rurópolis eram, por sua vez, um conjunto de agrópolis (CASTELFRANCHI, 2007).

Em escala crescente populacional e de organização, esses núcleos teriam infraestrutura necessária para atender às necessidades sociais desses migrantes, como por exemplo, escolas, hospitais, agências bancárias, entre outros. Entretanto, na prática, foram implantadas poucas agrovilas, apenas a agrópolis Brasil Novo e a Rurópolis Presidente Médice (CASTELFRANCHI, 2007). 
À época, chegavam ônibus lotados de pessoas em busca de melhores condições de vida, que recebiam lotes de terra do Governo Federal, mas sem qualquer subsidio financeiro ou condições que o permitisse produzir, ou seja, não houve a reforma agrária. O que de fato aconteceu é que, após a inauguração da Rurópolis Presidente Médice e da Rodovia Transamazônica em 1974, o governo abandonou os colonos e os deixou em um território desconhecido, com projetos inacabados, sem assistência técnica para produção e comercialização. Muitos que foram para região, seja para trabalhar ou colonizar, morreram de malária ou de febre amarela.

É neste contexto histórico que nasceu a Rurópolis Presidente Médice, como parte do município de Aveiro, com uma população rural, migrante, miserável, isolada e abandonada pelas políticas públicas. Em 1988, emancipou-se e, com status de cidade, extinguiu o nome do ditador passando a chamar-se somente Rurópolis (cidade rural, do grego).

Importa ressaltar que essas bases históricas de formação do território ruropolense e de sua população estão sustentadas em políticas públicas que não se consolidaram e que deixaram um contingente populacional marginalizado e abandonado em meio à selva amazônica, com núcleo urbano com pouca infraestrutura, mas com um hotel 5 estrelas construído somente para hospedar o presidente durante uma única noite na data de inauguração da Transamazônica. Relatos de antigos moradores revelam que o mesmo não chegou a pernoitar na cidade.

Foram milhares de agricultores e agricultoras, oriundos do Nordeste (retirantes da seca) e do sul do País, que buscavam terras agricultáveis e meios de produção, prometidos pelo governo federal, para prover melhores condições de vida para suas famílias. Sem condições de retornar à terra natal, esses colonos se organizaram em comunidades, associações, sindicatos, igrejas e formaram a população ruropolense que já nascia sob desigualdade social, com acesso restrito às políticas públicas e que ergueram uma cidade à base da agricultura e da pecuária.

Devido essa composição heterogênea de povos, a cultura e a culinária ruropolense não se expressam como tipicamente paraenses e amazônicas. As danças e comidas sulistas e nordestinas se sobressaem, da mesma forma saberes, práticas e crenças. Seu patrimônio histórico vem sendo depredado ao longo dos anos.

Seu território não possui comunidades indígenas ou quilombolas, apenas comunidades rurais e ribeirinhas, situadas ao longo dos $185 \mathrm{~km}$ rodovias federais (e suas estradas vicinais) e dos mais de 40 km de margem do rio Tapajós, respectivamente. Rurópolis tem grande potencial para o ecoturismo com inúmeras cachoeiras, rios e cavernas. Ressalta-se que é o $5^{\circ}$ município do Brasil em número de cavernas catalogadas e que possui inscrições rupestres em algumas delas. 
É um município de extrema pobreza. Em 2010, foi o $5.225^{\circ}$ município com menor índice de desenvolvimento humano (IDH 0,548) e o $4.938^{\circ}$ em produto interno bruto - PIB entre os 5.565 municípios do país (IBGE, 2010). Em 2016, o PIB foi de R \$ 7.119,47 (sete mil cento e dezenove reais e quarenta e sete centavos) por habitante, possuindo menor PIB da região do Tapajós e $120^{\circ}$ lugar entre os 144 municípios paraenses.

Em contraste, quando se trata de extensão territorial é o $203^{\circ}$ entre esses mais de 5.000 municípios, obtendo uma densidade populacional de 5,68 habitantes por $\mathrm{km}^{2}$. Com um território de 7.021,321 km², Rurópolis é maior do que países como Palestina $\left(6,020 \mathrm{~km}^{2}\right)$, Trinidad e Tobago $\left(5.130 \mathrm{~km}^{2}\right)$, quase o triplo de Luxemburgo $\left(2.586 \mathrm{~km}^{2}\right)$ e 15 vezes maior que o Vaticano $\left(0,44 \mathrm{~km}^{2}\right)$ (IBGE, 2010).

Ainda segundo o censo do IBGE em 2010, a população estudou até o ensino fundamental $(75,6 \%)$, morava na zona rural $(61,90 \%)$ e possuía renda per capita de $\mathrm{R} \$ 242,49$ (duzentos e quarenta e dois reais e quarenta e nove centavos) e obteve o índice Gini 0,57 (índice que mede a desigualdade social, em que 0 significa sem desigualdade e 1 significa muito desigual). Com $(73,89 \%)$ da população vulnerável à pobreza, $(65,35 \%)$ de pessoas com 18 anos ou mais com ensino fundamental incompleto e em ocupação informal.

Os empregos formais da cidade se concentram no funcionalismo público, pequena parte no comércio e em uma pequena indústria local enquanto os informais estão na agricultura, pecuária e no comércio. Vale ressaltar que são agricultores familiares e alguns produtores rurais, que se agruparam em dois sindicatos: o de trabalhadores rurais e dos produtores rurais. Estas instituições garantem a eles busca por direitos à seguridade social entre outras políticas públicas.

Entre as mães chefes de família, (16,73\%) não possuem ensino fundamental e tem filho menor. Rurópolis apresenta ainda $(24,40 \%)$ de taxa de mortalidade infantil, (70\%) de crianças de 0 a 5 anos fora da escola e, de todas as crianças, $(29,11 \%)$ são extremamente pobres. Entre as pessoas de 15 a 24 anos, $(31,27 \%)$ não estudam, não trabalham e são vulneráveis. Do total da população, somente $(27,71 \%)$ morava em domicílio com banheiro e água encanada (IBGE, 2010).

Rurópolis vem sofrendo algumas transformações em seu território devido grandes empreendimentos que se situaram nas áreas de influência da rodovia transamazônica e Santarém Cuiabá. Trata-se da construção de Usinas Hidrelétricas - UHE em Belo Monte e Tapajós, pavimentação das rodovias anteriormente citadas e Construção de portos graneleiros. Empreendimentos que vem para atender os anseios do capital, uma vez que a energia gerada se destina para manter as ricas regiões do país, os portos e a pavimentação para atender a 
exportação para o mercado internacional. Em suma, estes representam grande impacto ambiental, crescimento desordenado de cidades sem infraestrutura, desenvolvimento social e sustentável que geram processos de desgaste e fazem emergir processos de adoecimento da população.

Carente de infraestrutura urbana como sistema de esgoto, tratamento de água, gerenciamento de resíduos de forma sustentável, drenagem de águas pluviais e cuja população depende totalmente de educação e saúde públicas (única escola de ensino médio), Rurópolis é um cenário propício para o surgimento de diversos agravos, especialmente o escorpionismo.

A taxa de natalidade de Rurópolis é de $(8,37 \%)$ e com média de $(34,25)$ partos ao mês. Em 2017, nasceram 411 crianças de partos hospitalares, sendo (56\%) vaginais e (44\%) cesarianos. Em relação às consultas durante a gestação, $(0,97 \%)$ das mulheres não realizou consultas, $(4,62 \%)$ realizou de 1 a 3 consultas, $(28,18 \%)$ realizou de 4 a 6 consultas e $(66,18 \%)$ realizou 7 ou mais consultas pré-natal (DATASUS, 2019).

Possui alta incidência de gravidez entre jovens, sendo (1,70\%) entre 10 a 14 anos de idade e $(27,01 \%)$ de 15 a 19 anos. Entretanto, a maior proporção de mulheres grávidas está na faixa etária superior a 20 anos de idade, sendo (31,14\%) de 20 a 24 anos, (17,76\%) 25 a 29 anos, $(8,76 \%)$ de 35 a 39 anos e $(0,97 \%)$ tem mais de 40 anos (DATASUS, 2019).

Em 2017, a taxa de mortalidade geral foi de (2,04\%) com 100 óbitos, sendo (65\%) em homens e (35\%) em mulheres. Não houve mortalidade materna em 2017, em contraponto, a taxa de mortalidade infantil foi de $(21,90 \%)$ e taxa de mortalidade em menores de 05 anos foi de $(24,33 \%)$ (DATASUS, 2019).

As maiores causas de óbito são doenças do aparelho circulatório com (24\%), causas externas (17\%) e doenças do aparelho respiratório com (10\%). Em menor proporção, mas não menos importante, as neoplasias causam (7\%) e as doenças infecciosas e parasitárias causam (3\%) dos óbitos. Em relação ao local de ocorrência dos óbitos, (56\%) ocorreram em hospital, (26\%) em domicílio, (10\%) em via pública, (02\%) em outros estabelecimentos de saúde e (06\%) em outros locais (DATASUS, 2019).

Rurópolis tem alta prevalência de doenças diarreicas, hanseníase, leishmaniose, doenças sexualmente transmissíveis e acidentes por animais peçonhentos. No período de 2001 a 2017, aconteceram 1.841 acidentes por animais peçonhentos sendo 480 (26,07\%) acidentes ofídicos e 1.305 (70, 88\%) acidentes escorpiônicos (DATASUS, 2019).

Vale ressaltar que, no período de 2001 a 2006, a média anual de notificações de acidentes escorpiônicos era de 44,16 e, no período de 2007 a 2017, passou para 85,45 
(DATASUS, 2019). Esse incremento no número de casos mostra a estreita relação entre as mudanças no seu ecossistema e o agravo.

Em 2017, Rurópolis registrou 95 acidentes escorpiônicos, o que corresponde a (5,29\%) dos casos notificados no Pará. Em números absolutos, é o $6^{\circ}$ município do Estado em notificações de escorpionismo, ficando atrás de Prainha (141), Brasil Novo (137), Santarém (137), Altamira (114) e Uruará (104). Em números relativos, considerando o censo de 2010 e calculando a taxa a cada 1.000 habitantes, é $5^{\circ}$ município em casos de escorpionismo $(2,37)$, sendo que Brasil Novo fica na primeira posição $(8,56)$ seguido de Trairão $(5,53)$, Prainha $(4,70)$ e Medicilândia $(3,39)$. Ressalta-se que todos esses municípios pertencem à macrorregião III.

A dinâmica relação do ser humano com o meio ambiente, através do trabalho, e com o local onde vivem pode gerar processos de desgaste que oferecem condições que exponham os sujeitos à maior ou menor morbidade. Nessa dimensão, busca-se a compreensão das condições de vida, trabalho e de saúde, bem como as condições e características de como ocorre o processo saúde - acidente escorpiônico.

Nesta pesquisa, a maior parte dessa população de acidentados mora em casa de madeira, na zona rural, sem acesso a coleta de resíduos sólidos e que possui água encanada, porém sem o devido tratamento. Rurópolis não possui rede de esgoto.

São agricultores (as) que vivem com uma renda per capita inferior a 01 salário mínimo, residem em áreas sem infraestrutura e marginalizados pelas políticas públicas, propícios para proliferação do escorpião, configurando potenciais de desgaste para essa população. Borges (2004) observou, em seu estudo, que as áreas de maior ocorrência de acidentes escorpiônicos também são áreas de maior desigualdade social.

A maioria dos acidentados pertence à população negra $(84,62 \%)$ que historicamente, sofre exclusões, discriminações e com inserção social desqualificada/desvalorizada. Homens e mulheres negros acumulam desvantagens individuais, sociais e políticas que os tornam susceptíveis ao adoecimento (GUIMARÃES, 2001). Entre essas desvantagens, a pouca escolaridade impõe dificuldade de acesso à informação, formação e qualificação.

Entretanto, apesar das condições adversas, consideram-se saudáveis, a partir da concepção de saúde como presença ou não de doença. Diante do perfil de saúde dos acidentados com IMC adequado ao peso, a maioria nega tabagismo, etilismo, antecedentes mórbidos, alergias e que ainda não tinham sofrido acidente, considerou-se como potencial de fortalecimento e protetivo para o agravo.

Um dado interessante deste estudo é quase a metade, (44,30\%), já havia vivenciado o escorpionismo e, tanto em acidentes anteriores e quanto no acidente atual, identificou o animal 
envolvido como escorpião e, destes mais de (75\%) relatou que o animal era preto. Em Rurópolis nenhum paciente denominou o animal de lacrau e este dado difere de outros estudos realizados no Oeste do Pará. Nos estudos de Torrez (2016), Silva (2017), Oliveira (2018), respectivamente, $(87,5 \%),(57,8 \%)$ e $(36 \%)$ dos acidentados denominaram o animal causador de lacrau.

Esta experiência de vida, oportunizou saberes práticos sobre o agravo, uma vez que durante as entrevistas, os pacientes relatavam comparações entre o acidente atual e o anterior. Entretanto, uma parcela dos sujeitos dessa pesquisa, a partir do seu saber tradicional e popular, adotou práticas que consideram cuidados importantes durante o envenenamento, sendo a maioria ingestão de substâncias. Entre as substâncias ingeridas o fitoterápico Específico Pessoa foi o mais utilizado, entre outras substancias como soluções caseiras (suco da malva do reino, semente e chá da castanha de caju), bebida alcoólica (20\%) e ingestão de medicamentos. Alguns pacientes aplicaram substancias no local da picada ou aplicaram torniquete.

As dimensões e ordens de complexidade do objeto saúde podem explicar essas práticas de saúde. Especificamente na dimensão epistemológica (ideias sobre saúde) como campo teórico-prático em que se constrói objeto, conceito e "práxis" em saúde, a partir do ser intercultural ou unicultural. Portanto, a construção histórica do saber sobre saúde determina práticas que podem ser protetivas ou destrutivas. O desafio se encontra na desconstrução de práticas destrutivas que vem sido transmitidas tradicionalmente com integração de outros saberes (interculturalidade) e sem impor a episteme moderna (BREILH, 2006).

Em relação às circunstâncias do acidente, a maioria dos acidentados conseguiu chegar ao Hospital Municipal de Rurópolis em menos de 3 horas e este tempo para chegada ao atendimento em saúde foi considerado ágil, considerando as dimensões territoriais do município. Esses dados são concordantes com pesquisas realizadas no Oeste do Pará e em São Paulo, realidades tão distintas, que evidenciam que mais da metade das vítimas são atendidas nas duas e três primeiras horas do acidente (OLIVEIRA, 2018; RIBEIRO; RODRIGUES; JORGE, 2001). Este fato evita complicações dos quadros sintomáticos, pois indivíduos graves quando tratados após 3 horas do acidente apresentam risco de óbito 2,84 vezes, se comparado àqueles tratados em até 1 hora pós-acidente (RECKZIEGEL; PINTO JUNIOR, 2014).

$\mathrm{O}$ acidente escorpiônico é predominantemente matutino (06 às 12 horas) como também foi constatado em um estudo da Guiana Francesa (BENMOSBAH et al., 2013). Sendo o membro superior o local mais afetado, ocorrendo na execução trabalho, seja formal ou informal. O membro superior foi o local da picada com maior frequência com $(56,60 \%)$, 
achado também presentes nos estudos de Pardal et al., (2003), Reckziegel (2013) e Oliveira (2018).

Ressalta-se que o ambiente rural é o cenário propício para o acidente, especificamente em área livre (trabalho remunerado) e o domicílio (trabalho para subsistência), diferentemente do que ocorre nas regiões nordeste, sudeste, sul e centro-oeste, mas concordante como ocorre em toda região norte (RECKZIEGEL, 2013). A compreensão do contexto do acidente escorpiônico perpassa pelo movimento do ser humano no espaço geográfico e sua ação sobre ele e os contextos do acidente são diferentes para homens, mulheres, adultos e jovens.

Os acidentados, em sua maioria foram homens $(75,2 \%)$ de 21 a 40 anos $(38,45 \%)$, com pouca escolaridade e pouca qualificação profissional, portanto pertencente à população economicamente ativa, mesmo perfil encontrado nos estudos de Oliveira (2018). A pouca escolaridade, reflexo da dificuldade de acesso às políticas públicas e da desigualdade social, torna esta população vulnerável principalmente para assimilação de informações com qualidade e, por conseguinte, disponibilidade de recursos destinados à sua proteção (SANCHES; BERTOLOZZI, 2007).

Em um estudo no México, (45\%) das vítimas foram adultos com mais de 20 anos, mas, em relação à proporção por sexo, houve igualdade de incidência (BOUREE et al., 2005; CHOWEL et al., 2006). Entretanto, quando se remete ao cenário nacional e regional, os dados são concordantes. Na epidemiologia nacional, $(46,9 \%)$ dos acidentes concentraram-se na faixa etária de 20 a 49 anos e os homens foram mais acometidos (51,1\%) (RECKZIEGEL, 2013). Estudos realizados no Pará por Pardal et al. (2013) mostraram que a faixa etária mais atingida também é de adultos jovens. Torrez (2016), em sua pesquisa realizada em Santarém, mostrou que $(66 \%)$ das vítimas foram homens e a faixa etária mais atingida foi de 21 a 30 anos.

Nesta pesquisa, percebeu-se que o homem se acidenta mais na área rural enquanto a mulher se acidenta mais no domicílio, seja ele rural ou urbano. Este dado reflete claramente a divisão social do trabalho no ambiente rural, quando a agricultura desenvolveu processos de trabalho demasiadamente pesados que separaram as tarefas entre homens e mulheres, com a passagem do matriarcado ao patriarcado (RENTERIA; ESPINOSA, 2017).

Outra constatação é que as crianças e jovens do campo estão mais vulneráveis ao acidente, especialmente em seus domicílios, seja realizando tarefas cotidianas $(48,72 \%)$ ou de lazer $(15,39 \%)$. Sendo que, quando ele se acidente fora do lar e em área rural, a maioria se encontra no contexto do trabalho $(17,95 \%)$, como ajudante dos pais que veem esse trabalho como aprendizado de um ofício e não como atividade ilegal e penosa à criança. 
A partir dessa perspectiva, a família rural passou a ser uma unidade de produção e de transmissão hereditária dos bens, onde a mulher passou a se dedicar à horticultura, fruticultura, criação de animais, entre outras atividades realizadas na residência ou próxima a ela (RENTERIA; ESPINOSA, 2017). E crianças e jovens, conforme gênero, aprendem ou realizam tarefas distintas.

Analisando-se o local de ocorrência, o domicílio foi o mais frequente com $(50,95 \%)$ dos casos, sendo ele um domicílio rural $(28,30 \%)$ ou urbano $(22,65 \%)$. Dado semelhante ao encontrado em outro estudo no Pará onde (52\%) dos casos ocorreram em residência, (19\%) em ambiente externo e (3\%) em outros locais (MAESTRI NETO et al., 2008). Na Bahia, em torno de (92,3\%) dos acidentes escorpiônicos são domiciliares (AMORIM et al., 2003).

Este fenômeno é reflexo direto da ação antrópica sobre o ecossistema, o crescimento da área urbana sobre a mata, deixando o animal sem hábitat natural e sem alimento. Além disso, com desmatamentos crescentes na região, os predadores naturais do escorpião, tais como macacos, quatis, sapos e pássaros também são expulsos do local onde vivem, deixando-os livres, o que facilita ainda mais sua dispersão. Dessa forma, por terem facilidade de adaptar-se, esses animais aproximam-se das moradias, onde encontram alimento (COSTA, 2012).

Os acidentes escorpiônicos aconteceram o ano inteiro, sendo observada maior incidência de casos nos meses de abril, maio e junho e os meses menos prevalentes julho, agosto e setembro. Uma pesquisa realizada na Guiana Francesa constatou que os meses mais prevalentes são abril e maio e atribui ao fato de serem mais chuvosos do ano nas regiões e florestas tropicais (BENMOSBAH et al., 2013). Em relação aos meses mais prevalentes, um estudo realizado no período de 2000 a 2010, revelaram que os meses mais prevalentes no Brasil são outubro, novembro, dezembro e janeiro. Entretanto, quando se faz um recorte da região norte, neste mesmo estudo, os meses mais prevalentes são junho e julho (RECKZIEGEL; PINTO JUNIOR, 2014).

A maioria dos casos foi classificado como leve $(45,30 \%)$, sendo seguido por moderado $(33,33 \%)$ e graves $(03,42 \%)$. Importante demonstrar que $(17,95 \%)$ não foram classificados até o momento da alta hospitalar. Os pacientes hipertensos e diabéticos apresentaram-se mais vulneráveis durante o processo de adoecimento, uma vez que o veneno possui componentes adrenérgicos que poderiam agravar doenças cardiovasculares e endócrinas, como constatado nos exames laboratoriais e eletrocardiograma. Não houve letalidade no período.

Neste estudo, não houve associação significativa entre a classificação clínica do caso em relação ao tempo que o paciente levou até obter atendimento hospitalar e sua constituição corpórea do acidentado. Esse resultado não significa que crianças ou que maiores distâncias 
não são determinantes para o desfecho dos casos, devido a fragilidade que houve para classificação correta, uma vez que os testes estatísticos foram realizados a partir da classificação oficial atribuída pelo serviço de saúde pois diversos estudos regionais, nacionais e internacionais reforçam que esses fatores são determinantes para melhores prognósticos (CHOWELL et al., 2006; BERGMAN, 1996; BENMOSBAH et al., 2013; BOUAZIZ et al., 2008; GONZÁLEZ; SANTALÁN; POSSANI, 2018).

A realização desse estudo permitiu identificar algumas fragilidades em relação aos serviços de saúde, como distância e dificuldade de acesso às unidades de saúde. Quando acessa o nível de média complexidade, a maioria dos pacientes foi tratada com medicações sintomáticas e uma pequena parcela recebeu antiveneno específica, apesar de cerca de 1/3 dos casos ter apresentado sintomas da disfunção cerebelar aguda. Segundo Pardal e Gadelha (2010) e Torrez et al (2015), essas manifestações clínicas caracterizam casos moderados ou graves e, portanto, necessitariam ser tratados com antiveneno.

O Hospital de Rurópolis não possui protocolo clínico próprio documentado para manejo dos casos, sendo rotina administrar as medicações pré-antiveneno, mesmo naqueles casos em que não há indicação de antiveneno. A inexistência de protocolo atualizado, oficial e específico para os acidentes escorpiônicos da região dificulta classificação clínica adequada e, consequentemente, a terapêutica a ser adotada para cada caso. O Manual distribuído em 2010 pelo Estado foi edição limitada e o Manual do Ministério da Saúde não sofre atualização desde 2001.

Esses vieses dificultam a classificação clínica dos acidentes escorpiônicos ocorridos no Pará. Primeiramente não há um consenso entre os manuais estaduais e federais de manejo clínico desses acidentes, bem como os dois apresentam-se falhos na descrição do escorpionismo causado pelo T. obscurus e T. strandi.

No SUS, os Protocolos Clínicos e Diretrizes Terapêuticas (PCDT) são documentos oficiais que subsidiam o aperfeiçoamento do cuidado ao paciente, a partir de recomendações a serem seguidas por profissionais, gestores e pacientes acerca de uma determinada condição de saúde, garantindo assim a assistência terapêutica integral (MEGA et al., 2015). Esses protocolos otimizam a gestão em saúde e o cuidado ao paciente.

A equivocada classificação representa vulnerabilidade ao adoecimento ou agravamento do quadro, passo que reflete diretamente na administração da antiveneno. Este é um aspecto que remete à dimensão programática da vulnerabilidade ao acidente. Teoricamente, todos os casos moderados e graves necessitariam receber imunidade passiva, porém neste estudo verificou-se que (25\%) dos pacientes que necessitavam de antiveneno tiveram acesso a ela, seja 
pela falta de conhecimento ou seja pelo desabastecimento do imunobiológico no hospital (RECKZIEGEL, 2013; TORREZ, 2016).

Não há processo sistematizado de assistência de enfermagem e nem gerenciamento de risco para segurança das vítimas do escorpionismo, apesar das mesmas apresentarem diversos riscos, principalmente risco de queda e de lesão. Esses processos sistematizados de assistência são essenciais para o exercício da enfermagem com autonomia, baseada em conhecimentos técnicos-científicos, a partir do pensamento crítico e do reconhecimento de necessidades do paciente e da família (SILVA et al., 2011). Em relação à segurança do paciente, o gerenciamento de risco consiste em práticas que subsidiam cuidados e ações de enfermagem com excelência, propiciando assistência segura e de qualidade (COSTA; MEIRELLES; ERDMANN, 2013).

Ressalta-se um aspecto importante é a necessidade crescente de se qualificar a avaliação e o registro dos sintomas apresentados, principalmente em relação à sua localização, pois algumas manifestações clínicas consideradas locais, em alguns casos tomou proporções corporais, hemicorporais ou acometem segmentos completos.

Verificou-se que o serviço de saúde se limitava a disponibilizar atendimento de emergência e internação aos que se acidentassem, com administração de medicações e antiveneno específica quando necessitassem, com recolhimento das fichas de notificação para alimentação no SINAN e a quantidade de ampolas para alimentar o sistema de imunobiológicos. Constatou-se, portanto, que o fenômeno acidente escorpiônico é conduzido por dois eixos de interpretação: cuidado medicamentalizado e cuidado burocratizado.

$\mathrm{Na}$ medicamentalização, o cuidado se restringe à prescrição de medicamentos como única forma terapêutica possível de atender às situações da vida cotidiana (BEZERRA et al., 2014), principalmente no âmbito hospitalar. Não se prescreviam cuidados, somente medicamentos.

No âmbito da Vigilância em Saúde, os cuidados se limitavam a recolher as notificações preenchidas pelas equipes do hospital e dos postos de saúde, sem qualquer análise crítica, e alimentar os sistemas de informação, para que esses dados entrassem nas estatísticas oficiais que subsidiam o fornecimento de imunobiológicos para o município. Não eram feitos planejamentos ou ações, somente executavam as formalidades burocráticas que os órgãos de controle de agravos exigiam.

No entanto, é preocupante quando, em alguns casos, a unidade não dispunha de antiveneno e nem de câmara de imunobiológico para armazenamento adequado das ampolas. Em 2017, o Ministério da Saúde emitiu nota informativa para a utilização racional de 
antivenenos em que informa que os laboratórios produtores passavam por adequações, que os soros eram de difícil fabricação e que, portanto, os serviços de saúde receberiam quantidades criteriosas. No entanto, até o momento não foi regularizado o fornecimento de imunobiológicos.

Atualmente, o antiveneno escorpiônico é considerado o único tratamento específico para picada de escorpião e ele tem o objetivo de neutralizar o veneno do animal e minimizar sintomas, como a dor que melhora rapidamente com a infusão deste (BRASIL, 2001). Porém, esta pesquisa mostrou que a mediana de tempo de duração da dor foi igual entre pacientes que receberam e os que não receberam o SAESC. Quando comparado entre esses dois grupos, a mediana de tempo de duração dos sintomas ataxia de marcha, parestesia, choque elétrico, mioclonia, disartria e dismetria, constatou-se que a duração desses sintomas foi menor entre aqueles que não receberam o antiveneno.

Esses dados mostram o que muitos profissionais de saúde relatavam durante a pesquisa e que estudos de Torrez et al (2015) e Oliveira (2018) haviam constatado: o antiveneno produzido a partir do veneno do $T$. serrulatus não é eficaz no controle de sintomas neurológicos do escorpionismo na região oeste do Pará, no caso específico, em Rurópolis.

Um estudo de comparação dos venenos de T.obscurus e T. serrulatus demonstrou que as composições dos venenos são semelhantes em suas principais classes de proteínas produzidas e secretadas, embora suas sequências de toxinas sejam divergentes. Essas diferenças podem interferir na eficácia de antivenenos, produzidos a partir de outras espécies de escorpiões (inclusive $T$. serrulatus), no controle dos sinais e sintomas ocasionados pelo veneno do T.obscurus (DE OLIVEIRA et al., 2018)

Apesar da composição diferente, mas um estudo na Tunísia testou a eficácia do antiveneno com 600 pacientes, sendo divididos grupos homogêneos de casos e controles, cuja avaliação foi realizada a partir da taxa de alteração do grau de gravidade em ambos os grupos (melhora ou piora clínica durante um período de observação de pelo menos 4 horas). Os pesquisadores constataram que não houve alteração do curso clínico do escorpionismo e nem no tempo de internação (BLEGHITH et al., 1999).

Importa ressaltar ainda que este estudo registrou um caso de reação alérgica à infusão do antiveneno, mesmo administrando-se as medicações pré-antiveneno. No estudo de Torrez et al (2015) em Santarém, 03 (5,20\%) dos pacientes apresentaram reação adversa ao antiveneno, sendo 01 deles $(1,72 \%)$ com manifestações alérgicas como urticária e broncoespasmo. No estudo Bleghith et al (1999), realizado na Tunísia, três casos desenvolveram choque anafilático como consequência da administração do antiveneno. Na Índia, Bhoite et al (2015) e, em seu estudo, descreve o manejo clínico a um caso de anafilaxia grave ao antiveneno. 
O Ministério da Saúde (2001), no Manual de Diagnóstico e Tratamento de Acidentes por Animais Peçonhentos, afirma que a administração do soro é segura e que a liberação de adrenalina pelo veneno do animal seria uma condição de proteção às manifestações alérgicas. Bhoite et al (2015) afirmam que embora raras, reações graves de hipersensibilidade, incluindo anafilaxia ao antiveneno escorpiônico, são possíveis e precisam ser manejadas com presteza e qualidade.

A fragilidade da educação permanente no Estado, a falta de conhecimento das diversas realidades e cenários em saúde do Pará, acabam resultando em estatísticas inverídicas. Algumas inconsistências presentes no estudo, por exemplo, o número de casos leves foi maior que o número de pacientes que apresentaram somente sintomas locais enquanto que o número de casos moderados e graves foram inferiores ao número de pacientes que apresentaram sintomas sistêmicos.

Porém, apesar desses vieses, este estudo não apresentou letalidade e a distribuição da frequência de casos leves, moderados e graves estão de acordo com outros estudos realizados nos âmbitos regional e nacional (MAESTRI NETO et al., 2008; RECKZIEGEL, 2013).

Neste sentido, a grande extensão territorial dos municípios do oeste do Pará, as estradas intrafegáveis, principalmente no período chuvoso, bem como a existência de vazios assistenciais, tornam-se potenciais de desgaste no processo saúde e doença de populações rurais amazônicas. Entretanto, a compreensão e a luta para manter a floresta em pé torna-se um potencial de fortalecimento e proteção, não somente para prevenir o acidente escorpiônico, mas também para outros diversos agravos que advém da ação antrópica sobre os ecossistemas.

Importa ressaltar que os casos moderados se concentraram na faixa etária de adultos jovens, seguidos por adolescentes, idosos e crianças. Isto reflete a influência do modo de produção social, uma vez que as duas categorias mais frequentes estavam realizando trabalhos ou tarefas cotidianas.

Além disso, há necessidade de desenvolver um antiveneno eficaz para o acidente escorpiônico do Oeste do Pará, produzir em quantidade necessária à demanda e distribuir em tempo hábil para que não haja desabastecimento. Outro tópico importante é melhorar a rede de assistência regionalizada em saúde, investir em infraestrutura hospitalar municipal, ampliar a cobertura do PACS e das ESF, criar o Programa de Saúde da Família Rural para as Unidades que atendem zona rural e criar Unidades de Saúde da Família Rural, com financiamento e processo de trabalho diferenciado que propiciem acesso ao serviço de saúde. 
Quadro 05 - Marcadores de vulnerabilidade programática identificados nos dados obtidos das vítimas de acidente escorpiônico em Rurópolis, Pará.

\section{CATEGORIAS DEFINIDORAS DE VULNERABILIDADE PROGRAMÁTICA}

\begin{tabular}{lll}
\hline \multicolumn{1}{c}{ Eixos norteadores } & \multicolumn{1}{c}{ Marcadores } & \multicolumn{1}{c}{ Dados objetivos } \\
\hline $\begin{array}{l}\text { Quanto e como governos } \\
\text { respeitam, protegem e }\end{array}$ & - Corrupção no poder público nas diversas & - Estado do Pará com menor \\
promovem o direito à & esferas & investimento per capita para saúde. \\
qualidade da atenção em & - Estado neoliberal. & - Menor cobertura de Estratégia de \\
Saúde: & - Estado avançando com Leis que & Saúde da Família; \\
& fragilizam a saúde pública: novo & - Vigilância e educação em saúde \\
& financiamento da APS, PEC da & fragilizados (subfinanciados). \\
& desvinculação e Proposta de extinção do & - Só há o hospital Municipal de \\
& seguro DPVAT; & Santarém como referência de \\
& - Controle social fragilizado no cenário & Urgência e Emergência para a \\
& nacional, porém fortalecido no cenário & Região Oeste do Pará. \\
& municipal. O Hospital Regional do Baixo \\
& - Fragilidade das Comissões Intergestores & Amazonas é referência para Alta \\
& Regionais e bipartites (órgãos & acesso. \\
& deliberativos) & \\
& - Emendade, porém é de difícil \\
& - Financiamento insuficiente para & \\
& Vigilância em Saúde e Atenção Primária & \\
& - Rede hospitalar da região insuficiente e & \\
pouco estruturada para atender as & \\
necessidades da região. & \\
&
\end{tabular}

Grau e a qualidade do compromisso das diferentes instâncias da sociedade para a prevenção do acidente por escorpião;
- Governo Federal com atuação controversa para controle do desmatamento na Amazônia;

- Gerenciamento de resíduos precisa cobrir toda zona urbana e comunidades rurais; -As três esferas tem sido pouco atuantes para prevenção do acidente;

- Os materiais educativos existentes concentram-se na questão do manejo clínico e não na prevenção.
Existência de bases racionais e democráticas para a definição dos conteúdos dos programas de prevenção do acidente por escorpião.
- Em todas as esferas, a definição do conteúdo dos programas de prevenção do escorpionismo são centralizados no órgão gestor em saúde, principalmente por acreditarem se tratar de decisão técnica. - Fortalecimento da estratégia de Agentes Comunitários de Saúde para democratização para construção de programas de prevenção ao escorpionismo.
- Número de casos de acidentes em Rurópolis vem aumentando nos últimos anos.

- Aumento do desmatamento na Amazônia;

- Aumento do acidente escorpiônico domiciliar e urbano, em comparação a outros anos. - Inexistência de materiais educativos voltados para prevenção.

\section{- Pouca participação da} comunidade em decisões.

Organização dos serviços
de saúde (planejamento,
avaliação e
monitoramento) para
prestação de cuidado com
qualidade.

Organização dos serviços de saúde (planejamento, monitoramento) para qualidade.
- Fragilidade do planejamento, avaliação e monitoramento;

- Instrumentos avaliativos possuem vieses;

- Planejamento é descendente;

- Os sistemas de informação nem sempre traduzem a realidade em saúde;

- Os planos municipais de saúde deveriam preceder Leis orçamentárias;
- A avaliação e monitoramento ficam prejudicados quando o planejamento é falho.

- Planejamento deve ser ascendente;

- Notificações incompletas não geram relatórios fidedignos que 


\begin{tabular}{|c|c|c|}
\hline & $\begin{array}{l}\text { - Os planos municipais de saúde deveriam } \\
\text { ser construídos coletivamente; } \\
\text { - Não há ações/metas sobre escorpionismo } \\
\text { no plano municipal; } \\
\text { - Melhorar a qualidade do registro de } \\
\text { notificações; } \\
\text { - Qualificar equipe multiprofissional para } \\
\text { melhorar o manejo clínico, prevenção e } \\
\text { promoção à saúde. } \\
\text { - Otimizar o uso de antivenenos. }\end{array}$ & $\begin{array}{l}\text { subsidiem ações de Vigilância e de } \\
\text { Terapêutica. } \\
\text { - Casos sem classificação. }\end{array}$ \\
\hline $\begin{array}{l}\text { Instituição de Políticas } \\
\text { Públicas voltadas aos } \\
\text { acidentes por escorpião. }\end{array}$ & $\begin{array}{l}\text { - Centro de Informações Toxicológicas - } \\
\text { CIT somente na capital do Estado. } \\
\text { - Política de Educação Permanente em } \\
\text { Saúde fragilizada; } \\
\text {-A vigilância em saúde prioriza agravos } \\
\text { financiados e que constem no quadro de } \\
\text { metas estadual. } \\
\text { - Não há política e financiamento para } \\
\text { Equipes de Saúde da Família Rural; } \\
\text { - Pouca aplicabilidade prática da Política } \\
\text { Nacional de Saúde Integral da população } \\
\text { do campo e da floresta. }\end{array}$ & $\begin{array}{l}\text { - Difícil e pouco acesso dos } \\
\text { municípios ao CIT. } \\
\text { - Monitoramento de Acidentes por } \\
\text { Animais Peçonhentos não compõe } \\
\text { as metas do Programa de } \\
\text { Qualificação das Ações de } \\
\text { Vigilância em Saúde -PQAVS } \\
\text { - As unidades de Saúde seguem } \\
\text { programas pensados para zona } \\
\text { urbana, focadas na doença, cunho } \\
\text { sexista e na geração. } \\
\text { - Não distinção de financiamento } \\
\text { para manutenção de Unidades de } \\
\text { Saúde na zona urbana e na zona } \\
\text { rural. }\end{array}$ \\
\hline $\begin{array}{l}\text { Correta avaliação do grau } \\
\text { de gravidade do acidente }\end{array}$ & $\begin{array}{l}\text { - Dificuldade em classificar a gravidade } \\
\text { devido as atuais diretrizes não } \\
\text { contemplarem as manifestações do } \\
\text { envenenamento por T.obscurus e T. } \\
\text { strandi. } \\
\text { - Discordância entre o número de } \\
\text { classificações leve, moderado e grave } \\
\text { com o número de pacientes que } \\
\text { apresentaram somente manifestações } \\
\text { locais e de pacientes que apresentaram } \\
\text { manifestações locais e sistêmicas. } \\
\text { - Alguns sintomas considerados locais, } \\
\text { como a dor e parestesia podem tomar } \\
\text { proporções corpóreas amplas. } \\
\text { - Alguns sintomas considerados sistêmicos } \\
\text { podem ser locais (Ex: sensação de choque } \\
\text { elétrico) } \\
\text { - Complexidade e variedade de } \\
\text { apresentação clínica do escorpionismo. } \\
\text { - Poucos treinamentos e capacitações para } \\
\text { profissionais de saúde para prevenção e } \\
\text { manejo clínico dos acidentes por animais } \\
\text { peçonhentos. } \\
\text { - Ausência de classificação na ficha de } \\
\text { notificação e prontuários. } \\
\text { - Indisponibilidade de antiveneno em } \\
\text { quantidade suficiente para atender os casos } \\
\text { moderados e graves. }\end{array}$ & $\begin{array}{l}\text { - Casos sem classificação. } \\
\text { - Número de casos leves } \\
\text { superior ao número de pacientes } \\
\text { que apresentaram somente } \\
\text { sintomas locais. } \\
\text { - Número de casos moderados e } \\
\text { graves inferior ao número de } \\
\text { pacientes com manifestações } \\
\text { sistêmicas. } \\
\text { - Falta de antivenenos na rede } \\
\text { pública de saúde. }\end{array}$ \\
\hline $\begin{array}{l}\text { Estrutura do serviço de } \\
\text { saúde conforme } \\
\text { recomendações para } \\
\text { prevenção }\end{array}$ & $\begin{array}{l}\text { - Dificuldade de acesso aos serviços de } \\
\text { saúde, principalmente os que habitam áreas } \\
\text { rurais. } \\
\text { - Pouca cobertura de Estratégias de Saúde } \\
\text { da Família }(53 \%) \text {; }\end{array}$ & $\begin{array}{l}\text { - Existência de } 04 \text { unidades de } \\
\text { saúde na zona rural (possui mais de } \\
200 \mathrm{Km} \text { de estradas e vicinais) } \\
\text { - Existência de } 01 \text { Equipe de Saúde } \\
\text { da Família Ribeirinha }\end{array}$ \\
\hline
\end{tabular}


- Ampla cobertura do Programa de Agentes

Comunitários de Saúde.

- Mensuração de Agentes de Combate às

Endemias por imóveis e não por extensão territorial ou populacional.

- Inexistência de educação em saúde para

população em relação aos acidentes escorpiônico.

- Indisponibilidade de informativos para população nas unidades de saúde.
- Existência de áreas descobertas de ACS.

- Poucos ACE na zona urbana e na zona rural.

- Unidades de Saúde não abordam o acidente por animal peçonhento em suas ações educativas;

- As Secretarias de Saúde estadual e municipal não produzem materiais educativos para distribuir à população para prevenção do agravo.

Capacitação para o manejo - A capacitação aos acidentes por animais do acidente peçonhentos são prejudicados pela ausência de protocolos clínicos que dificultam classifica-los.

- Não captura ou registro do animal para a correta identificação

- Estratégias de educação permanente em saúde devem ser adotadas para todos os profissionais de saúde da rede pública. - Implementação da Política de Educação Permanente baseada na realidade local.

Uso adequado de medicamentos e imunobiológicos nos serviços de saúde, visando o alívio da dor, desconforto e ansiedade
- De 117 pacientes, somente 06 trouxeram o animal para identificação.

- Ausência de capacitações relacionados ao tema com profissionais de saúde na região e no município.
- Medicações pré-antiveneno só devem ser administradas em casos em que há indicação de SAESC.

- Não administrar medicamentos via intramuscular nos acidentados.

- A dificuldade em classificar adequadamente os casos, levam à administração incorreta do antiveneno. - Disponibilidade insuficiente de imunobiológicos ao número e gravidade dos casos.

- Assistência segura, humanizada e qualificada: não realizar toques bruscos; oferecer ambiente seguro e tranquilo.

\author{
- A maioria recebeu medicamentos \\ pré-antiveneno, sem necessidade; \\ - Casos moderados não puderam \\ receber imunobiológico por \\ desabastecimento do Hospital; \\ - Casos leves receberam \\ imunobiológico, apesar de não \\ terem indicação para tal; \\ - Falta de imunobiológicos no \\ Hospital para atender a demanda; \\ - Medicações administradas \\ intramuscular podem potencializar \\ a rabdomiólise e desconforto ao \\ paciente; \\ - Pacientes referem aumento da \\ intensidade de dor irradiada e \\ sensação de choque elétrico ao \\ toque.
}

Adequação da rede de frios - Inadequação do espaço e infraestrutura da - Falta de imunobiológicos no e logística em saúde rede de frios municipal. - Sala de imunobiológicos do Hospital de fácil acesso aos profissionais de saúde. - Preenchimento inadequado da ficha de notificação.

- Alimentação irregular dos sistemas de informação.

- Pouco abastecimento do $9^{\circ}$ Centro Regional para atendimento das demandas

Oferta de tratamento de - Serviços de Saúde municipais são equipados para manejo de pacientes leves e moderados, porém não atende às necessidades de pacientes graves;

- Ausência de exames laboratoriais mais específicos como ionograma e gasometria arterial;

- Ausência de equipamentos de suporte ventilatório para adultos no HMR.
Hospital para atender a demanda.

- Casos não notificados e sem informações em sistemas.

- Casos com notificações incompletas;

- Casos notificados sem preenchimento da classificação de gravidade.

- Dificuldade para transferir pacientes graves ao Hospital de referência Regional (Hospital Municipal de Santarém).

- Somente 01 UTI neonatal (06 leitos), 01 UTI Pediátrica (10 leitos porém 07 deles ocupados com pacientes residentes e 2 UTI adulto com 20 leitos. Insuficiente para 
- Poucos leitos de Unidade de Terapia Intensiva- UTI na região Oeste do Pará;

- Hospitais de referência gerenciados por Organizações Sociais - OS que reduziram, nos últimos anos, o acesso aos serviços de média e alta complexidade. uma região com população de mais de 1 milhão de habitantes.

- Gerenciamento terceirizado precariza o trabalho, a qualidade da assistência e reduz capacidade de atendimento em função de "controle de gastos".

- Não há informações aos usuários sobre direitos em relação à assistência segura. visem a segurança do paciente, apesar de tecnicamente os profissionais conhecerem e monitorarem os riscos envolvidos em casos de escorpionismo.

Profissionais de saúde com - Aumento da migração para o Município carga de trabalho em excesso. nos últimos anos;

- Recursos humanos qualificados escassos.

- Quantitativo de profissionais aumentou pouco nos últimos 15 anos.

- Recursos financeiros escassos para ampliação do quadro de funcionários e Lei de Responsabilidade Fiscal.

- Falta de concursos públicos nos últimos 14 anos.

- O alto valor cobrado por médicos para trabalhar em municípios menores.

- Ampliação da relação médico/habitante após a implantação do Programa mais médicos- PMM.

- Financiamento de Equipes de Atenção

Primária em Saúde condicionada à presença do médico.
Disponibilização de equipamentos e materiais que buscam garantir a segurança para não ocorrência de acidente

- Acidentados não relatam uso de Equipamento de Proteção Individual;

- Poucos recursos (equipamentos e materiais) disponíveis ou mesmo inexistentes.

- Recurso financeiro limitado para aquisição de EPI

- Inexistência de materiais educativos que abordem cuidados com a saúde baseados na realidade local, para que o escorpião não se aproxime da residência. Ex: criação de galinhas (predadoras) ao ar livre ao invés de presas em galinheiros.

Participação na elaboração e consenso sobre as normativas locais.
- Os municípios aguardam diretrizes nacionais e estaduais. Pouquíssimos elaboram consensos para normativas locais. - Os consensos ainda partem da gestão em saúde, de forma centralizadora.

- Pouca participação popular em momentos e espaços democráticos municipais.
- Investimento em qualificação dos profissionais efetivos do município;

- Subfinanciamento do SUS;

- Pouca arrecadação municipal (15\%);

- Último concurso público foi em 2005;

- Médicos cobram, no mínimo, 30 mil reais para trabalharem 30 dias no município;

- PMM como suporte aos pequenos municípios.

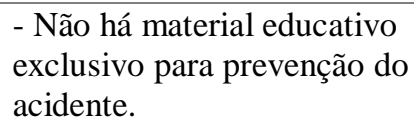
exclusivo para prevenção do acidente.

\author{
- Inexistência de consensos e ou \\ documentos norteadores das \\ práticas em Rurópolis.
}

A vulnerabilidade programática se expressa na capacidade de acesso aos serviços de saúde, a partir de sua organização, estabelecimento de vínculo com território e com o usuário, realização de ações preventivas e de controle ao escorpionismo bem como recursos sociais existentes no território da Unidade de Saúde (BERTOLOZZI et al., 2009). 
Mann, Tarantola e Netter (1993) propuseram os seguintes parâmetros para análise da vulnerabilidade programática relacionadas ao HIV/AIDS mas que se adequam ao escorpionismo: expressão do compromisso, transformação do compromisso em ação, desenvolvimento da coalizão, planejamento e coordenação, gerenciamento, respostas às necessidades de prevenção individuais e coletivas, repostas às necessidades de tratamento, obtenção de recursos financeiros, sustentação do esforço, avaliação do programa e avaliação do impacto.

No entanto, constatou-se que desses 11 passos elencados pelos autores, o município de Rurópolis estava realizando parcialmente o passo 7 que trata das respostas às necessidades de tratamento que consistem em dar acesso e melhorar a qualidade do tratamento, uma vez que a disponibilização do antiveneno estava prejudicada. Passos importantes como criar programa, enfrentar o problema de forma específica, desenvolver ações intersetoriais e interinstitucionais, estabelecimento de parcerias governamentais e não governamentais para implementar o programa, elaborar plano de ação que contemple as populações vulneráveis, treinamento de recursos humanos, realizar intervenções em respostas às necessidades de indivíduos e coletivos, obtenção de recursos específicos para continuidade do programa, sintonia entre este e a sociedade, avaliação e retroavaliação do mesmo bem como desenvolvimento de avaliações periódicas do impactos do programa não estavam sendo realizados no município.

No entanto, com essa pesquisa, percebe-se a dimensão do fenômeno que precisa ser trabalhado desde o espaço domiciliar, comunitário, até os níveis de alta complexidade que possivelmente uma vítima de escorpionismo requeira. São necessárias ações de educação popular e permanente, de promoção à saúde, de prevenção ao agravo e de assistência ao acidentado (protocolos clínicos), sendo todas essas faces de um mesmo problema. No entanto, é necessário sensibilizar os profissionais para a realidade de saúde do território ruropolense, especialmente às equipes que atuam na zona rural.

Este estudo revela a dimensão do agravo e sua importância como um problema de saúde pública no município, que requer compreensão de todo processo para que então se possa interferir nos desfechos, seja ele para o polo saúde ou polo doença.

Na dimensão estrutural, o cenário brasileiro de uma sociedade capitalista marcada por profundas desigualdades sociais que passa por uma instabilidade política produzida de forma consciente, a partir de interesses ideológicos ou por busca do poder, que resultou em uma crise econômica que acentua a pobreza e fez ascender ao poder de grupos políticos ultraneoliberais que visam a venda do patrimônio público e a minimização de direitos adquiridos. 
Nos últimos anos, percebe-se um crescimento (ou desvelamento) do fascismo, do fanatismo religioso e político que permite o desmonte de direitos, da cidadania, ataca professores, universidades, cientistas e classe artística como justificativa de combater pensamentos diversos aos seus e que acreditam ser "nocivos à sociedade". Neste cenário, o Brasil mostra-se polarizado entre os que defendem a diversidade e os direitos sociais e os que defendem uma sociedade conservadora, preconceituosa e desigual.

O Estado ultraneoliberal, nos últimos dois anos, avançou com políticas de desmonte de direitos sociais como: a) a Emenda Constitucional 95 que congela o financiamento da saúde, educação e seguridade social por 20 anos; b) a fragilização do controle social, extinguindo por decreto algumas comissões, comitês e conselhos; c) a fragilização dos sindicatos e dos direitos trabalhistas; d) a nova proposta de reforma da previdência que mantém regalias e altos vencimentos a poucos e reduz os vencimentos de muitos, obrigando-os a trabalhar por mais tempo, expondo-se ao adoecimento; e) o projeto de Emenda Constitucional que propõe a desvinculação do orçamento, retirando a obrigatoriedade de investimento mínimo em saúde e educação, principalmente; f) a fragilização dos órgãos de controle ambiental e g) a política de privatização de diversos patrimônios públicos.

Neste contexto, o Sistema Único de Saúde vem sofrendo uma asfixia financeira que se intensificou após mudanças em seu financiamento, que aos poucos inviabilizam o sistema universal, gratuito, acessível, integral, equânime e de qualidade. Mendes (2019) afirma que essa asfixia está sustentada em 05 principais eixos: a) insuficiência de recursos e baixo volume de gastos com recurso público; b) indefinição de fontes de recursos; c) ausência de maior comprometimento do Governo Brasileiro, destaca Federal e Estadual; d) Elevadas transferências do setor público para o setor privado e e) gasto público financiado por uma estrutura tributária defasada à "dinâmica do capitalismo financeirizado" e que tende a penalizar os mais pobres.

O autor ressalta que o subfinanciamento do SUS é histórico, mas que nos últimos anos vem sofrendo reduções importantes. Em 2015, a União investia 4,14\% dos recursos públicos em saúde e em 2017 reduziu para 3,16\%. No entanto, a União gastou 42,43\%, em 2015, e passou a gastar 50,66\%, em 2017, dos recursos públicos com juros e amortização da dívida externa (MENDES, 2017).

Assumindo esse caráter, o governo brasileiro acaba por reduzir o acesso à saúde de qualidade. O financiamento do SUS continua sendo baseado na população, sem considerar realidades e desigualdades regionais, bem como a dimensão territorial e sua densidade demográfica, que são barreiras para o acesso e melhorias dos serviços de saúde. 
Além disso, o SUS vem sofrendo mudanças em algumas políticas, retrocedendo ao modelo centrado na figura do médico, como se evidencia na nova Política Nacional de Atenção Básica- PNAB e na proposta de mudança de financiamento da Atenção Primária em Saúde. Este modelo, remonta ao modelo hospitalocêntrico, biologicista e positivista, que não favorece a visão do ser humano com um ser social e histórico que se busca para se alcançar a compreensão de necessidades e vulnerabilidades em saúde.

Levando em consideração a região norte do país, o cenário da saúde pública brasileira se torna mais desesperadora, principalmente porque é nesta região que existem os maiores bolsões de pobreza e inequidade. É a região com menor desenvolvimento econômico, altos índices de desigualdade social, baixo IDH, muitos conflitos por terra, maior desmatamento. Apesar de alguns avanços no SUS nos últimos 30 anos, entre os sete Estados nortistas, o Pará é o que menos investe em saúde, considerando-se o investimento per capita (CONASEMS, 2018). Infelizmente, não é só em saúde que se constatam poucos investimentos. Neste contexto, é relevante conhecer os aspectos políticos e econômicos do Pará, estado onde se realizou o estudo.

Grandioso em extensão territorial e com a maior população da região Norte, em 2010, ocupava a $9^{a}$ posição em população, com densidade demográfica de $6,07 \mathrm{hab} / \mathrm{km}^{2}$. É o estado com o $24^{\circ}$ índice de desenvolvimento humano do país $(0,646)$ e $23^{\circ}$ no ranking no índice do desenvolvimento da educação básica - IDEB (4,5) (IBGE, 2010).

Em relação ao produto interno bruto - PIB per capita, em 2015, o Pará apresentou o menor índice da região norte e o ficou em $22^{\circ}$ no ranking nacional, com $\mathrm{R} \$ 16.689,55$ (dezesseis mil, seiscentos e oitenta e nove reais e cinquenta e cinco centavos) por habitante. Quanto ao rendimento mensal domiciliar per capita o valor foi $\mathrm{R} \$ 863,00$ (oitocentos e sessenta e três reais), $20^{\mathrm{a}}$ no ranking. E ainda apresenta um PIB per capita que reflete intensa desigualdade social entre seus municípios, onde o município de Canaã dos Carajás apresentou o valor de R \$ 103.806,81 (cento e três mil, oitocentos e seis reais e oitenta e um centavos) por habitante enquanto que o município de Cachoeira do Piriá apresentou o valor de $\mathrm{R} \$ 4.824,65$ (quatro mil, oitocentos e vinte e quatro reais e sessenta e cinco centavos) (IBGE, 2015).

É um estado historicamente é marcado pela exploração da natureza pelo homem (atividades extrativistas, mineração e exploração de recursos hídricos) e da exploração do homem pelo homem (em garimpos, fazendas, comércio e indústria). Atualmente, apresenta-se como nova fronteira agrícola nacional e vem sofrendo com o processo da "nova ruralidade" com altos investimentos no campo, uso indiscriminado de agrotóxico e desmatamento. 
O Pará é palco de conflitos fundiários e violência no campo, onde são ameaçados e assassinados ativistas que lutam pelo direito à terra (sindicalistas no Sul do Pará), à saúde (Conselheiros de Saúde no nordeste do Estado), à educação (professores no nordeste do Estado) e ao meio ambiente (ativistas da região do Marajó e do Xingu, destaca-se aqui a morte da freira Dorothy Stang). Entretanto, percebe-se também que a mão do Estado está presente na repressão à movimentos organizados que lutam por reforma agrária (como no caso da chacina de Eldorado dos Carajás) ou mesmo contra jovens negros das periferias de Belém (chacinas nos Bairros Guamá, Terra Firme e Jurunas).

Por longos anos, o Estado é governado por grupos políticos ligados com esquemas de corrupção e que concentravam investimentos na região metropolitana, que lhes ofereciam maior quantidade de votos. Essa discrepância no investimento no território estadual, fez surgir movimentos separatistas no Sul e no Oeste do Pará, cujos Estados seriam denominados Carajás e Tapajós, respectivamente.

Na região Oeste do Pará, os municípios que comporiam o Estado do Tapajós seriam aqueles das regiões do Xingu, Baixo Amazonas e Tapajós, com total de 27 municípios, que representam cerca de 20\% da população do Estado com 1.300.090 habitantes em um território que representa 58\% do território atual do Pará. Este estado nasceria com uma população duas vezes maior que o Estado de Roraima e com a $3^{\text {a }}$ posição em extensão territorial, ficando atrás de Amazonas e Mato Grosso. O movimento separatista ainda está ativo e articulando com parlamentares um novo plesbicito, uma vez que no primeiro, toda a população do Estado foi consultada e a maioria foi contrária à ideia de divisão territorial.

Os municípios da região vêm sofrendo algumas transformações em seu território devido grandes empreendimentos que se situaram nas áreas de influência da rodovia transamazônica e Santarém Cuiabá. Trata-se da construção de Usinas Hidrelétricas - UHE em Belo Monte e Tapajós, pavimentação das rodovias anteriormente citadas e Construção de portos graneleiros. Empreendimentos que vem para atender os anseios do capital, uma vez que a energia gerada se destina para manter as ricas regiões do país e os portos e a pavimentação para atender a exportação para o mercado internacional. Em suma, estes representam grande impacto ambiental, crescimento desordenado de cidades sem infraestrutura, desenvolvimento social e sustentável.

Além das UHE, a região também virou uma nova fronteira agrícola com a vinda de produtores de outros estados, principalmente do Mato Grosso via rodovia Santarém-Cuiabá, que chegam para comprar milhares de hectares de terra e em busca de maior proximidade com portos para o escoamento de seus produtos. Entre esses portos, destacam-se o da Cargill na 
cidade de Santarém, o de Miritituba na cidade de Itaituba e, futuramente, o de Santarenzinho na cidade de Rurópolis.

Ressalta-se ainda, que um projeto chinês da construção de uma ferrovia que ligaria o Estado do Mato Grosso ao porto de Santarenzinho tramita na esfera do governo federal com o objetivo de otimizar o tempo de escoamento dos produtos agrícolas brasileiros (especialmente a soja) para os mercados internacionais. Com estes empreendimentos, a região sofreu um segundo fluxo migratório intenso que acentuou o desmatamento, aprofundou a desigualdade social e fez aumentar a violência na cidade e no campo.

O processo de desmatamento e queimadas na região, que se intensificaram em 2019, representam maior vulnerabilidade ao acidente por animal peçonhento, uma vez que o animal perde seu habitat natural e a passa a procurar alimentos, que geralmente estão disponíveis próximos aos domicílios. Em outra análise, o crescimento urbano desordenado também promove maior vulnerabilidade social, ao passo que crescem conglomerados sem a infraestrutura habitacional necessária, como saneamento básico e gerenciamento de resíduos, propiciando a vinda de animais famintos ao ambiente urbano e domiciliar.

A partir dessa análise, avaliando os indicadores da macrorregião III, que reúne municípios das regiões Baixo Amazonas, Tapajós e Xingu, no período de 2001 a 2006, percebeu-se que o acidente ofídico (5.123 casos) era mais incidente que o acidente escorpiônico (4.067 casos). Esta lógica inverteu no período de 2007 a 2017, quando o escorpionismo (14.151 casos) superou o ofidismo (11.288 casos). Importa ainda ressaltar que a média anual de acidentes escorpiônicos nesta macrorregião passou de 677,83 casos, no período de 2001 a 2006, para 1.286,45 casos, no período de 2007 a 2017.

Apesar dessa mudança de incidência nos tipos dos acidentes causados por animais peçonhentos, a macrorregião III sempre foi a que mais notificou escorpionismo no Estado do Pará. No período de 2001 a 2006, apresentou uma incidência de 4.067 acidentes escorpiônicos que correspondeu a 77,01\% dos 5.281 casos notificados em todo Estado. No período de 2007 a 2017, foram notificados 14.151 casos que equivaleram a $77,21 \%$ dos 18.327 acidentes escorpiônicos notificados no Pará. Esses dados mostram a significância deste agravo para população desta macrorregião.

A compreensão e apreensão desse contexto social, econômico e histórico permitiu a construção do quadro de marcadores de vulnerabilidade social abaixo (quadro 06). 
Quadro 06 - Marcadores de vulnerabilidade social identificados nos dados obtidos das vítimas de acidente escorpiônico em Rurópolis, Pará.

CATEGORIAS DEFINIDORAS DE VULNERABILIDADE SOCIAL

\begin{tabular}{|c|c|c|}
\hline Eixos norteadores & Marcadores & Dados objetivos \\
\hline $\begin{array}{l}\text { Desenvolvimento } \\
\text { econômico e social do } \\
\text { país, Estado, região } \\
\text { Oeste do Pará e } \\
\text { Rurópolis. }\end{array}$ & $\begin{array}{l}\text { - Pouco investimento em políticas de } \\
\text { desenvolvimento sustentável } \\
\text { - Concentração do desenvolvimento e } \\
\text { investimento nas regiões sul e sudeste } \\
\text { - Crescimento desordenado sem } \\
\text { desenvolvimento econômico: surgimento de } \\
\text { novos bairros em Rurópolis, avançando } \\
\text { desmatamento. } \\
\text { - Grande extensão territorial e baixa } \\
\text { densidade populacional: distâncias para } \\
\text { acesso ao serviço de saúde. } \\
\text { - Corrupção no poder público: pouca } \\
\text { infraestrutura e disponibilidade de serviços } \\
\text { de saúde. } \\
\text { - Acirramento das desigualdades sociais e } \\
\text { regionais: população negra maior vítima do } \\
\text { acidente. } \\
\text { - Aumento da violência no campo e nas } \\
\text { cidades. } \\
\text { - Rurópolis nasceu sob desigualdade social e } \\
\text { abandonada pelas políticas públicas. } \\
\text { - Rurópolis com baixo IDH e com pior PIB } \\
\text { da região do Tapajós. } \\
\text { - Agricultores formaram sua população e são } \\
\text { os mais afetados pelo escorpionismo. } \\
\text { - Acidentados fazem parte da população } \\
\text { economicamente ativa que sofre acidente, } \\
\text { em sua maioria, no contexto do trabalho. }\end{array}$ & $\begin{array}{l}\text { - Região norte apresenta menor } \\
\text { desenvolvimento econômico } \\
\text { - Estado do Pará com alto índice de } \\
\text { desigualdade social, baixo IDH, com } \\
\text { conflitos por terra. } \\
\text { - População com menor renda per } \\
\text { capita para saúde. } \\
\text { - Rurópolis, município rural remoto, } \\
\text { de extrema pobreza, eminentemente } \\
\text { rural. } \\
\text { - Falta de equipamentos essenciais } \\
\text { para saúde e para o controle de } \\
\text { qualidade de imunobiológicos como } \\
\text { câmara de conservação no Hospital } \\
\text { Municipal de Rurópolis. }\end{array}$ \\
\hline Bases democráticas & $\begin{array}{l}\text { - Instabilidade política e econômica do } \\
\text { governo federal } \\
\text { - Estado ultraneoliberal e conservador } \\
\text { - Política de minimização de direitos e da } \\
\text { cidadania } \\
\text { - Política de privatização de bens e serviços } \\
\text { - Crescimento do fascismo e da intolerância. }\end{array}$ & $\begin{array}{l}\text { - Impeachment e novas eleições } \\
\text { federais; } \\
\text { - Reformas antidemocráticas; } \\
\text { - Aumento do tempo de contribuição } \\
\text { para previdência (exposição ao } \\
\text { acidente). } \\
\text { - Privatização do pré-sal } \\
\text { - Aumento da intolerância e crimes } \\
\text { de ódio e injúria racial. }\end{array}$ \\
\hline $\begin{array}{l}\text { Relação entre Estado e } \\
\text { sociedade civil }\end{array}$ & $\begin{array}{l}\text { - Controle social fragilizado } \\
\text { - Estado com ações que fragilizam a saúde e } \\
\text { a educação pública sem consultar o controle } \\
\text { social. } \\
\text { - Fragilização dos sindicatos e dos direitos } \\
\text { trabalhistas. } \\
\text { - Conselhos nacional, estadual e municipal } \\
\text { de Saúde atuantes; } \\
\text { - Maior proximidade e presença do governo } \\
\text { do Estado na região Oeste do Pará. } \\
\text { - Rurópolis com governo democrático e } \\
\text { participativo. }\end{array}$ & $\begin{array}{l}\text { - Extinção de algumas comissões, } \\
\text { comitês e conselhos pelo atual } \\
\text { presidente. } \\
\text { - Extinção da contribuição sindical } \\
\text { obrigatória } \\
\text { - Governo do Estado criou a } \\
\text { Secretaria Regional de Governo, uma } \\
\text { subgovernadoria em Santarém, para } \\
\text { estar mais próximo da região } \\
\text { separatista do oeste do Pará. } \\
\text { - Fortalecimento da participação do } \\
\text { controle social, criação e resgate de } \\
\text { Conselhos, como do meio ambiente, }\end{array}$ \\
\hline
\end{tabular}


- Existência de sindicatos de Produtores

Rurais, de Trabalhadores Rurais, Associação de Mulheres do Campo e da Cidade, Associação de Moradores de Bairro e de comunidades rurais.

- Parte dos acidentados são sindicalizados. agricultura e da previdência

municipal. Existência no município de Conselho Tutelar e do Direito da Criança, Conselho do Fundo da Educação Básica Conselho de Saúde. - Não há conselho fiscal ou conselho da cidade;

Políticas sociais
públicas e
intersetorialidade
(desenvolvimento
agrário, controle
ambiental, logística
nacional e de
transportes,
pavimentação de
rodovias, geração de
energia e Vigilância
em Saúde)

- Região norte como nova fronteira agrícola

- Grandes projetos hidrelétricos na região do Tapajós

- Avanço do desmatamento na região norte

- Fragilização dos órgãos de controle ambiental.

- Pavimentação das rodovias 230 e 163.

- Melhor política de educação no campo;

- Rurópolis em situação geográfica estratégica para logística nacional.

- Futuras instalações de portos graneleiros em Rurópolis.

- Crescimento urbano sem desenvolvimento sustentável e sem planejamento.

- Avanço de doenças tropicais e acidentes por animais peçonhentos
- Impactos ambientais de

hidrelétricas.

- Aumento do êxodo rural.

- Crescimento desordenado de cidades.

- Aumento das mazelas sociais e violência.

- Aumento do número de acidentes de trânsito, acidentes por animais peçonhentos, DST/AIDS, ressurgimento de doenças tropicais e doenças emergentes na Amazônia.

\section{- Financiamento baseado em dados} suficiente e estável. populacionais sem contextualizar a realidade social, ambiental e geográfica do território.

- Subfinanciamento do Sistema Único de Saúde e congelamento de seu financiamento por 20 anos.

- Pouco investimento em educação em saúde e educação permanente.

- Lei Kandir, isenção fiscal das empresas multinacionais/nacionais proveniente da exploração dos minérios

- Pouca arrecadação municipal para subsidiar as diversas ações de saúde.

- Irrisório repasse de recursos financeiros para a saúde pelo governo estadual
- Sucateamento do SUS

- Proposta de mudanças no financiamento da Atenção Básica.

- Congelamento do financiamento do recurso para saúde - Emenda

Constitucional 95

- PEC da desvinculação

- Mudanças no financiamento da Atenção Básica Estadual

- Arrecadação municipal insuficiente. Não há emissão de nota fiscal na cidade e nem recolhimento de impostos (água, Imposto Predial Territorial Urbano, Imposto sobre Serviços e outros)

\section{Conformação de normativas de âmbito nacional e internacional de prevenção e controle dos acidentes com escorpião}

- Carência de pesquisas na área das doenças negligenciadas, entre elas os acidentes por animais peçonhentos.

- Desatualização de guidelines ou manuais acerca dos novos espectros de envenenamentos por escorpião.

- Carência de pesquisas para composição de soro escorpiônico mais eficaz e eficiente que atenda às diversidades dos venenos da escorpiofauna brasileira

- Apesar de ser um grave problema de saúde pública, o escorpionismo ainda não é tratado como uma das prioridades na política de saúde brasileira.
- Investimento insuficiente em pesquisas.
- Estudos escassos na área da prevenção e vulnerabilidades ao escorpionismo.
- Manual de Diagnóstico e Tratamento de Acidentes por Animais Peçonhentos vigente é do ano de 2001.
- Soro antiescorpiônico não apresenta eficácia contra o envenenamento por $T$. obscurus $e$ T. strandi.
- Poucas pesquisas direcionadas aos acidentes por animais peçonhentos, especialmente na Amazônia.

- Não existe um plano de educação permanente no Estado que alcance 


\begin{tabular}{|c|c|c|}
\hline & $\begin{array}{l}\text { - Educação permanente fragilizada } \\
\text { - Investimento insuficiente para divulgação } \\
\text { de informações em diversos meios de } \\
\text { comunicação } \\
\text { - Poucas Tecnologias educativas } \\
\text { direcionadas ao tema. }\end{array}$ & $\begin{array}{l}\text { todas as regionais de Saúde do Pará, } \\
\text { em especial ao } 9^{\circ} \text { Centro, na cidade } \\
\text { de Santarém. } \\
\text { - Redirecionamento dos recursos da } \\
\text { educação permanente para outras } \\
\text { áreas de saúde. } \\
\text { - Inexistências de campanhas ou } \\
\text { financiamento para campanhas para } \\
\text { prevenção de acidentes por animais } \\
\text { peçonhentos. }\end{array}$ \\
\hline $\begin{array}{l}\text { Estigma/ crenças } \\
\text { religiosas/ }\end{array}$ & $\begin{array}{l}\text { - Cultura de automedicação de forma } \\
\text { caseira. } \\
\text { - Saberes e Práticas culturais tradicionais } \\
\text { - Algumas práticas podem ser nocivas }\end{array}$ & $\begin{array}{l}\text { - Amazônia, cenário rico de } \\
\text { populações tradicionais e saberes } \\
\text { milenares. } \\
\text { - Uma parcela dos acidentados } \\
\text { ingeriu substâncias químicas ou } \\
\text { aplicou substâncias no local da } \\
\text { picada, como prática de cuidado. }\end{array}$ \\
\hline
\end{tabular}

Para Ayres et al (2009) a vulnerabilidade social busca a compreensão do contexto social. Neste sentido, o quadro da vulnerabilidade social reflete a realidade de muitos municípios brasileiros, especialmente do norte do país. Populações vivenciam processo de extração de suas riquezas, seja por meios escusos ou por exploração de sua natureza, sem ter retorno sustentável com políticas que assegurem os direitos constitucionais, como acesso à saúde e educação de qualidade.

Vivencia-se um processo de "desenvolvimento econômico" regional relacionado à logística nacional de exportação de grãos, geração de energia e ampliação da fronteira agrícola, que se traduzem em mais desmatamentos, agravos à saúde e mais mazelas sociais advindas de crescimento sem planejamento e sem desenvolvimento. Para Oliveira (2018), os registros de acidentes escorpiônico ocorridos no período de sua pesquisa podem ser associados às transformações espaciais e sociais ocorridas na região na última década.

Aliado a isso, o momento histórico da política nacional em um governo que adota reformas que aprofundaram a desigualdade social, ampliaram a exploração do trabalho e exposição a doenças ocupacionais e legislações que limitam o financiamento da saúde e da educação por 20 anos. Em um cenário desse, não há como vislumbrar potenciais de fortalecimento e de redução de vulnerabilidades. Um estado que dificulta e ainda reduz o financiamento sustentável às políticas sociais necessárias para atender os direitos dos cidadãos, não é um Estado Democrático de Direito.

Percebe-se, portanto, que a Amazônia e, especificamente, a região do Tapajós precisam ainda de investimentos em políticas básicas que impactam diretamente nos indicadores de saúde, como: a) saneamento básico e coleta de resíduos; b) trafegabilidade de rodovias e investimento para que o cidadão consiga chegar ao serviço de saúde e vice-versa; c) ofertar 
mais serviços para fortalecer a rede de atenção à saúde na região; d) investimentos em conectividade para que a informatização da saúde seja uma realidade em todos os municípios; e) financiamento diferenciado para que dê subsídio às ações de saúde no território; f) investimentos em tecnologias sustentáveis e g) programas de saúde que atendam às especificidades da população do campo. E nesse contexto, percebe-se uma negligência histórica aos direitos básicos do cidadão nesta região.

As necessidades sociais e em saúde na região evidenciam claramente que o acidente escorpiônico representa um grave problema e que requer investimentos em pesquisas para doenças negligenciadas, especialmente acidente por animal peçonhento, e para composição de soro que atenda a diversidade de venenos da escorpiofauna brasileira.

Ainda se percebe a carência de ações de educação em saúde, voltadas à temática, nas três esferas de governo, evidenciada pela dificuldade de compreensão e execução da política de educação permanente. Há pouca tecnologia educativa direcionada aos acidentes escorpiônicos e investimento insuficiente para divulgação de informações em diversos meios de comunicação, para maior alcance da população. Torrez (2019) ressalta a importância da educação para profissionais e estudantes de graduação em saúde acerca do escorpionismo para melhor controle desse problema de saúde pública.

No caso do escorpionismo, percebe-se a necessidade de uma atitude "cuidadora" intersetorial e multidisciplinar que envolva outros campos como economia, meio ambiente, agricultura, educação e assistência social, pois é importante diversas perspectivas para que haja uma verdadeira mudança estrutural. Como afirma Ayres (2001), a atitude de cuidar não se limita às práticas de saúde e que a atitude "cuidadora" precisa envolver a totalidade de reflexões e intervenções no campo da saúde (SANCHEZ; BERTOLOZZI, 2007).

Nesse contexto, importa ressaltar que o escorpionismo é uma realidade de populações pobres e que esta pobreza não consiste apenas falta de acesso a bens e serviços, mas também na falta de acesso às políticas públicas de qualidade que possibilite alternativas, mecanismo de participação de construção dessas políticas, como também ausência de resolução de conflitos e precariedade nas relações ambientais sustentáveis (BRASIL, 2013).

Percebe-se, portanto, que população ruropolense é vulnerável socialmente ao escorpionismo, pois apresenta dificuldade de obtenção de informações de qualidade e frágeis recursos cognitivos e materiais. Entretanto, alguns acidentados apresentam potenciais de fortalecimento, como acesso aos meios de comunicação, principalmente rádio, televisão e redes sociais virtuais e, principalmente os trabalhadores rurais, participam de sindicatos, associações, 
comunidades e instituições religiosas que lhes permitem participar de decisões políticas. Esses elementos são avaliados na vulnerabilidade social (AYRES et al., 2009).

5.3 Proposta de uma matriz de análise da vulnerabilidade aos acidentes escorpiônicos

A análise do escorpionismo passa necessariamente pelo resgate histórico da formação das populações e do território. Para além da compreensão dos aspectos epidemiológicos, clínicos e terapêuticos, mais relativos aos casos, foi necessário buscar uma compreensão ampliada do fenômeno à luz do entendimento da Determinação Social do Processo Saúde e Doença.

O fenômeno escorpionismo é multidimensional e dinâmico, portanto necessita de práticas de intervenção intersetorial e multidisciplinar para redução de inequidades, proteção ambiental, proteção no mundo do "fazer" e qualificação do cuidado em saúde desde o planejamento até o produto final da intervenção com os diferentes grupos sociais.

Neste sentido, o conceito da vulnerabilidade possibilitou o reconhecimento e visão acerca do escorpionismo que acomete indivíduos, com modos de vida peculiares, inseridos em contextos social, ambiental, econômico, cultural e político que o determina ao adoecimento. Padoveze et al. (2018) afirmam que a vulnerabilidade aumenta a possibilidade o enfrentamento de indivíduos ou grupos sociais a partir do reconhecimento de potenciais de desgaste e de fortalecimento e que, portanto, estes não vivenciam o processo saúde e doença passivamente.

No quadro 08, apresenta-se a Matriz de análise das dimensões de vulnerabilidade aos acidentes por escorpião em Rurópolis, onde se destaca os principais marcadores presentes em cada dimensão. 


\section{Quadro 07 - Categorias analíticas das dimensões da Vulnerabilidade das vítimas de acidente escorpiônico em Rurópolis, Pará.}

\section{INDIVIDUAL}

Reconhecimento da pessoa como sujeito de direito e busca da participação em construções coletivas, fiscalização e efetivação de políticas públicas.

Saberes que os indivíduos, famílias e grupos possuem sobre $\mathrm{o}$ escorpião, sobre o acidente em si, sobre o meio ambiente e formas de prevenção do escorpionismo.

Práticas, representações, crenças, valores, que os indivíduos, famílias e grupos mantém para prevenção do acidente e para o cuidado com as vítimas.

Modos de vida, produção e reprodução social

Suscetibilidade ao acidente: seu lugar no território, questões de gênero, geração, classe social e raça/cor.

Condição de saúde: IMC, doenças pregressas (cardiovasculares, renais, neuromusculares, hematológicas e endócrinas) e histórico de acidente anterior

Adesão às medidas de prevenção no trabalho e no cotidiano

\section{SOCIAL \\ PROGRAMÁTICO \\ COLETIVA}

Rurópolis: contexto histórico de desigualdade social, tríplice inequidade e abandono pelo poder público

Grandes empreendimentos na Amazônia: necessidade de desenvolvimento econômico, social e ambiental

sustentável.

\section{Ameaça às bases} democráticas: fragilização e marginalização do controle e dos movimentos sociais.

Políticas públicas para intersetorialidade: agricultura, Assistência Social, Educação, Meio Ambiente, Saneamento Básico, Transportes e logística nacional e Minas e Energia.

\section{Subfinanciamento do SUS}

Desmatamento e queimadas na Amazônia.

Conformação de normativas de âmbito nacional e internacional de prevenção e controle dos acidentes com escorpião

Disponibilização de equipamentos e materiais que buscam garantir a segurança para não ocorrência de acidente.

-Vazios populacionais na Amazônia e baixa densidade demográfica.
Necessidade de melhor cobertura de Atenção Primária em Saúde e proposição de Unidade de Saúde da Família Rural.

Compromisso multiprofissional, intersetorial e interdisciplinar para a prevenção, controle e manejo do acidente por escorpião;

Qualificação, atualização e investimento no programa de controle de acidentes por animais peçonhentos.

Base democráticas para definição de planos e metas para saúde, incluindo programas de prevenção do acidente.

Melhor execução e financiamento das políticas para prevenção do escorpionismo: Vigilância em Saúde (imunização), Saúde da População do Campo e da Floresta, Saúde do Trabalhador e Saúde do Homem.

Educação Permanente em Saúde sobre escorpionismo: correta avaliação do grau de gravidade do acidente, manejo do acidente, uso adequado de medicamentos e imunobiológicos nos serviços de saúde

Adequação da rede de frio e logística em saúde

Tratamento de suporte com segurança e humanização, visando conforto e alívio da dor e da ansiedade.

Carga de trabalho dos profissionais de saúde.

Participação na elaboração e consenso sobre as normativas locais.

Infraestrutura e rede hospitalar de referência

Dificuldade de acesso ao serviço de saúde

Formação do Profissional de Saúde 


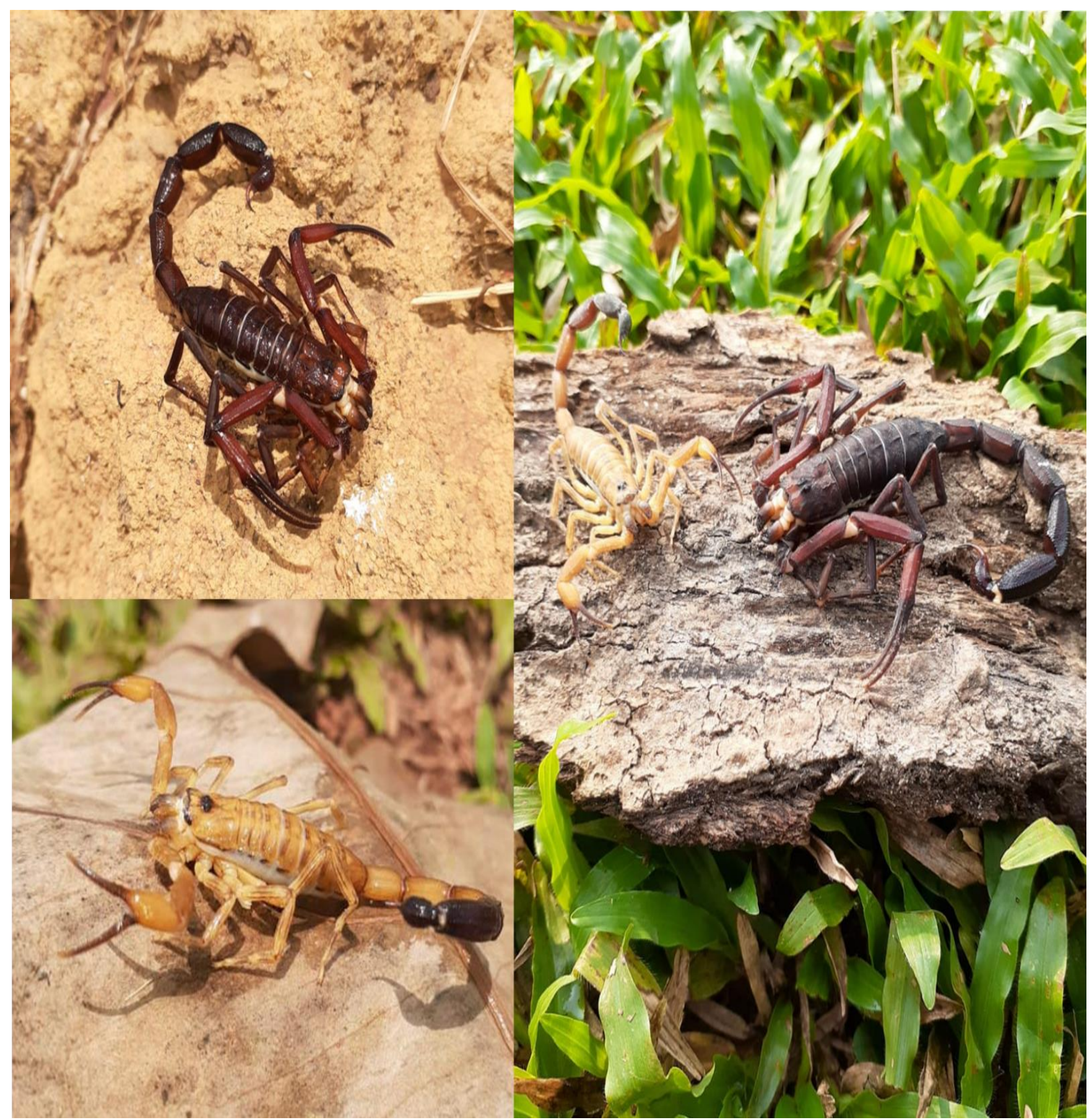




\section{CONSIDERAÇÕES FINAIS}

O acidente escorpiônico em Rurópolis, assim como a região oeste paraense, apresentase de forma peculiar, cuja incidência aumenta com o avanço desordenado dos centros urbanos sobre a floresta, precárias condições de saneamento básico e gerenciamento de resíduos. Trata-se de um fenômeno multidimensional e dinâmico presente em espaços de pobreza e se configura como agravo negligenciado. Acrescenta-se ao processo, o contexto e o espaço amazônico continental que impõe barreiras naturais que dificultam o acesso às políticas de saúde.

O estudo permitiu elaborar uma matriz de análise na perspectiva do conceito de Vulnerabilidade, conforme os objetivos específicos de "Analisar aspectos epidemiológicos, clínicos e terapêuticos destes acidentes" e de "Descrever a vulnerabilidade individual e coletiva aos acidentes escorpiônicos". Sintetizado na seguinte conclusão:

Evidenciou-se marcadores de vulnerabilidades sociais, programáticas e individuais que muitas vezes se entrelaçam e transitam nas dimensões.

A desigualdade social que se expressa em condições sociais e de acesso às políticas públicas compõem marcadores de vulnerabilidade social e individual ao escorpionismo. Homens negros e trabalhadores rurais estão mais expostos ao acidente escorpiônico e são propensos a sofrer mais de um acidente escorpiônico no decorrer da vida.

Os homens se acidentam mais no campo na ocasião do trabalho enquanto que mulheres e crianças se acidentam no domicílio, na realização de tarefas domésticas do cotidiano. Ou seja, a realização do trabalho, seja formal, informal ou do cotidiano, no campo ou no domicílio conferem vulnerabilidade individual ao escorpionismo, principalmente nos membros superiores.

O conhecimento tradicional determina práticas que podem ser nocivas à saúde.

Neste estudo foi constatado que $T$. strandi também é um escorpião clinicamente importante.

A presença de manifestações cardiovasculares também pode conferir vulnerabilidade individual ao agravamento clínico. E estas são potencializadas se o paciente já possuir histórico de doenças cardiovasculares e endócrinas.

As manifestações clínicas tem componentes motores e sensitivos que dificultam o autocuidado ao paciente, causam grande desconforto e levam à rabdomiólise. 
Em Rurópolis, as vítimas de escorpionismo também apresentam disfunção cerebelar aguda, no entanto esta não é um quadro exclusivo do acidente por escorpião preto pois também foi constatada em acidentes causados por escorpiões amarelos.

Acrescentam-se manifestações oftalmológicas (diplopia e sensação de areia nos olhos), digestivas (disgeusia e espasmo faríngeo) e neurológicas (convulsão) ao quadro clínico do escorpionismo na Amazônia.

A vulnerabilidade programática expressa a angústia vivenciada por muitos profissionais e gestores em saúde. Primeiramente, sem acesso à educação permanente e sem financiamento adequado não há política de saúde de que se consolide. A inexistência de um consenso nacional e regional sobre o manejo clínico dos casos de escorpionismo, que levam em cadeia, vulnerabilidades como classificação e utilização de imunobiológicos de forma inadequada.

A produção limitada de imunobiológicos, a falta de estrutura adequada à rede de frios e falta de equipamentos e materiais para suporte aos casos graves também são reflexos do investimento limitado na área. $\mathrm{O}$ antiveneno não se mostrou eficaz na remissão dos sintomas neurológicos apresentados pelos pacientes do estudo e ainda pode causar reações alérgicas durante sua administração.

Proporcionar o número adequado de profissionais de saúde devidamente qualificados, que participem da construção de diretrizes clínicas, é um dos passos importantes para que se tenha uma educação em saúde voltada tanto para prevenção, mas também para o manejo clínico adequado dos pacientes.

Essas são conclusões do estudo, mas abre-se novas possibilidades de estudo sobre: identificação de novas espécies clinicamente importantes, composição e produção de novos antivenenos que contemplem os acidentes amazônicos, pesquisas de intervenção nos marcadores de vulnerabilidade evidenciados, pesquisas com exames diagnósticos para investigação de efeitos hematológicos do veneno do escorpião na Amazônia, pesquisas sobre o impacto do desmatamento sobre a saúde das populações amazônicas e pesquisas voltadas para o tema são necessários para reduzir vulnerabilidades, principalmente programáticas (classificação clínica).

O protagonismo da enfermagem na Amazônia se constata na execução, acesso e produção de serviços de saúde. Portanto, este estudo contribui no âmbito individual e coletivo, ao trazer uma abordagem mais ampla sobre a determinação do escorpionismo em Rurópolis, mudando a forma de se planejar e intervir, buscando maior resolutividade. 
Uma mudança necessária à enfermagem no cenário amazônico é mudança de captar a realidade objetiva que se apresenta aos olhos e não apenas seguir protocolos e cronogramas impostos pelo Ministério da Saúde.

É necessária essa mudança de olhar principalmente nas unidades presentes nas áreas rurais cujos programas executados não contemplam a dimensão da família do campo. Para tanto, este estudo propõe a mudança de paradigma e de processo de trabalho de serviços de saúde rurais, visando principalmente o acesso, prevenção e promoção deste agravo e de outros que acometem principalmente famílias rurais.

Outra contribuição para enfermagem é propor mudança da prática na assistência hospitalar que hoje está concentrada na medicalização que pode conferir mais vulnerabilidade se realizado de forma desnecessária e/ou inadequada. A enfermagem de Rurópolis precisa melhorar e qualificar sua avaliação e registro dos casos de escorpionismo, buscando um olhar crítico sobre o processo de saúde e histórico do indivíduo que, por hora, está dependente de seus cuidados.

A compreensão do papel do Enfermeiro na Vigilância em Saúde também necessita ser ressignificado pois, geralmente, o Ministério e as Secretarias de Saúde tendem a exigir metas e números que não dão conta do contexto real de um agravo. É preciso superar o conceito de risco e pensar a partir dos contextos de vulnerabilidade. É difícil essa mudança de paradigma quando a única forma de ver o mundo é a luz da epidemiologia clássica. Neste sentido, este estudo tentou trazer uma nova perspectiva à luz da epidemiologia crítica e da vulnerabilidade.

No entanto, sabe-se que o fenômeno Escorpionismo é multifacetado e que a Enfermagem precisa compor uma equipe maior, multiprofissional e intersetorial, com objetivo de prevenir o acidente. Os esforços de diversos setores são necessários, pois, como foi constatado na matriz de análise da vulnerabilidade, o agravo é o desfecho de uma condição de susceptibilidade que a população de Rurópolis está exposta, desde sua fundação no Plano de Integração Nacional.

Porém, no cenário amazônico, o Enfermeiro se gradua para atuar no SUS e, quando esse profissional atua com raciocínio crítico sobre a realidade e desperta para sua capacidade de promover transformação social e de saúde, a partir da sua prática, os resultados não podem ser reduzidos a números. Espera-se que este estudo contribua para esse despertar! 


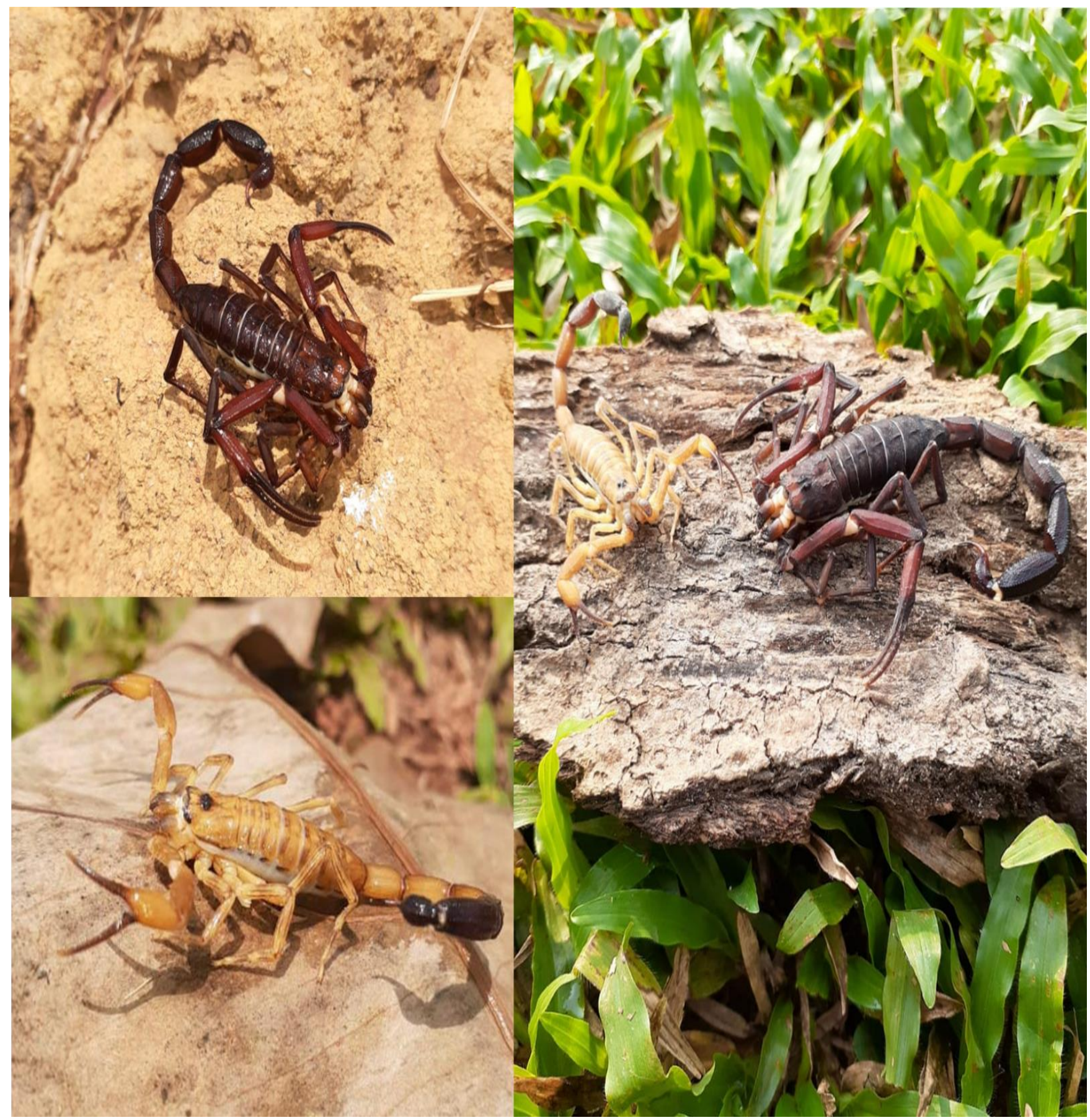




\section{REFERÊNCIAS}

AMITAI, Y. Clinical manifestation and management of scorpion envenomation. Public Health Reviews, v.26, p.257-263, 1998.

AMORIM, A. M. et al. Acidentes por escorpião em uma área do Nordeste de Amaralina, Salvador, Bahia. Brasil. Revista da Sociedade Brasileira de Medicina Tropical, v.36, n.1, p.51-56, jan-fev, 2003.

AYRES, J.R.C.M. et al. Vulnerabilidade e prevenção em tempos de AIDS. In: Barbosa R, Parker R, organizadores. Sexualidade pelo avesso: direitos, identidades e poder. Rio de Janeiro: Relume Dumará,1999.

AYRES, J.R.C.M. et al. Risco, vulnerabilidade e práticas de prevenção e promoção de saúde. In: Campos, G.W.S. Tratado de Saúde Coletiva. Rio de Janeiro: Hucitec Fiocruz, 2006.

BATISTA, C.V. et al. Proteomics of the venom from the Amazonian scorpion Tityus cambridgeii and the role of prolines on mass spectrometry analysis of toxins. Journal of Chromatography B, v.803, p.55-66, 2004.

BATISTA, C.V. et al. Scorpion toxins from Tityus cambridgeii that affect $\mathrm{Na}(\mathrm{p})$-channels. Toxicon, v.40, p. 557-562, 2002.

BAWASKAR, H.S.; BAWASKAR,P.H.; BAWASKAR, P.H. Pathophysiology of dilatation of pupils due to scorpion and snake envenomation and its therapeutic value: Clinical observations. Indian Journal of Oftalmology, v.65, n.1, p.67-70, 2017.

BOYER, L.V. et al. Antivenom for Critically Ill Children with Neurotoxicity from Scorpion Stings. N Engl J Med, v.360, p. 2090-2098, 2009.

BENGUEDDA, A. C. et al. Experience de quinze annees de lutte contre l'envenimation scorpionique en Algerie. Bull. Soc, p. 205-208, 2002.

BENMOSBAH, $\mathrm{M}$ et al. Estudo epidemiológico e clínico sobre o escorpionismo na Guiana Francesa. Toxicon, v.73, p. 56-62, 2013. doi: 10.1016 / j.toxicon.2013.05.025.

BERGMAN, N.J. Clinical description of Parabuthus Transvaalicus scorpionism in Zimbabwe. Toxicon, v. 35, n. 5, p. 759-771, 1997.

BERTOLOZZI, M.R. et al. Os conceitos de vulnerabilidade e adesão na saúde coletiva. Rev Esc Enferm USP, v.43, p.1326-30, 2009. Número especial.

BEZERRA, I.C. et al. "Fui lá no posto e o doutor me mandou foi pra cá": processo de medicamentalização e (des) caminhos para o cuidado em saúde mental na Atenção Primária. Interface Comunicação Saúde Educação, v.18, n.48, p.61-74, 2014.

BLEGHITH, M. et al. Efficacy of serotherapy in scorpion sting: a matchef-pair study. J.Toxicol clin.Toxicol, v.37, n.1, p.51-57, 1999. 
BORGES M. A. F. S. A vigilância epidemiológica dos acidentes por escorpiões: uma abordagem no campo da saúde coletiva. 2004. Tese (Doutorado em Ciências) - Escola de enfermagem, Universidade de São Paulo, São Paulo.

BOUAZIZ, M; BAHLOUL, H; KALLEL, H; SAMET, H; KSIBI, H; DAMMAK, H; AHMED, M.N; CHTARA, K; CHELLY, H; HAMIDA,C.B; REKIK, N. Epidemiological, clinical, characteristics and outcome of severe scorpion envenomation in South Tunisia: Multivariate analysis of 951 cases. Toxicon, v.52, n.8, p.918-26, 2008.

BOUREE, P. et al. Les piqures de scorpion: un probleme de sante publique a Morelos (Mexique). Cahiers Sante, 2005.

BRASIL. Ministério da Saúde. Fundação Nacional de Saúde. Manual de Diagnóstico e Tratamento de Acidentes por Animais Peçonhentos. Brasília: Ministério da Saúde, 2001.

BRASIL. Ministério da Saúde. Secretaria de Vigilância em Saúde. Departamento de Vigilância Epidemiológica. Manual de controle de escorpiões. Brasília: Ministério da Saúde, 2009.

BRASIL. Portal da Saúde [Internet]. NOTA INFORMATIVA: Informações da Coordenação-Geral de Doenças Transmissíveis (CGDT) referentes à nova abordagem ao tratamento em casos de acidentes por serpentes do grupo Bothrops ("jararacas") e por escorpiões, em situação de escassez de antivenenos. 2016. Disponível em: http://portalsaude.saude.gov.br/index.php/o-ministerio/principal/leia-mais-o-ministerio/197secretaria-svs/24972-nova-abordagem-ao-tratamento-em-situacao-de-escassez-deantivenenos. Acesso em 15 de janeiro de 2019.

BRASIL. Ministério da Saúde. SINAN NET. Secretaria de Saúde de Rurópolis, 2011.

BRAZIL T. K.; PORTO, T. J. Os escorpiões. Salvador: Edufba, 2010.

BREILH, J; MUÑOZ, Y.T. Aceleracion global y despojo in ecuador: el retrocesso del derecho a la salud em la era neoliberal. 1 Ed.. Ediciones Abyl Yala. Quito: Universidad Andina Simon Bolivar, 2009.

BREILH, J. Epidemiologia Crítica: ciência emancipadora e interculturalidade. Rio de Janeiro: Editora FIOCRUZ, 2006.

BROWNELL, P.; POLIS, G. Scorpion biology and research. New York: Oxford University Press, 2001.

CAMPOLINA, D. et al. Escorpionismo. In: ANDRADE FILHO, A.; CAMPOLINA, D.; DIAS, M.B. Toxicologia na prática clínica. 2 ed. Belo Horizonte: Folium, 2013.

CAMPOS, G.W.S. et al. (org). Tratado de saúde coletiva. São Paulo: Hucitec; 2009. p. 41 80.

CARDOSO, F. J. T. et al. Escorpionismo em Rurópolis-Pará: Descrição de casos, In: IV CONGRESSO DO HOSPITAL UNIVERSITÁRIO JOÃO DE BARROS BARRETO/UFPA: ATENÇÃO À SAÚDE COM RESPONSABILIDADE SOCIAL, 2011.Belém. Anais. Belém: HUJBB, 2011. 
CARDOSO, F. J. T. et al. Escorpionismo em Rurópolis, Oeste Paraense. In: $67^{\circ}$ CONGRESSO BRASILEIRO DE ENFERMAGEM, 2015, São Paulo. Anais. São Paulo: ABEN Seção SP, 2015.

CARDOSO, F.J.T. et al. Estudos de caso: Acidente escorpiônico no Município de RurópolisPA. Em Foco, v.4, n.17, p.51-56, 2012.

CARVALHO, L. S; SANTOS, M. P. D; DIAS, S. C. Escorpionismo na zona rural de Teresina, Estado do Piauí: relato de casos de envenenamento. Revista da Sociedade Brasileira de Medicina Tropical, v.40, n.4, p.491, 2007.

CASTELFRANCHI, Y. Poeiras e esperanças na Transamazônica de hoje. Rev Com Ciência. 2004. Disponível em http://www.comciencia.br/200404/reportagens/07.shtml. Acesso em 10 de outubro de 2019.

CHIPPAUX, J. P.; GOYFFON, M. Epidemiology of scorpionism: a global appraisal. Acta Trop, v.107, p. 71-79, 2008.

CHOWELL, G. et al. Epidemiological and clinical characteristics of scorpionism in Colima, Mexico (2000-2001). Toxicon, v.47, n.7, p.738-753, 2006.

CODDINGTON, J. A.; COLWELL, R. K. Arachnida. In: LEVIN, S. C. (Org.). Encyclopedia of biodiversity. New York: Academic Press, p.199-218, 2001.

CONASEMS, Conselho Nacional de Secretarias Municipais de Saúde. 30 anos CONASEMS. ISSN 1679-9259. Brasília: CONASEMS, 2018.

COSTA, C.L. S. O. Aspectos epidemiológicos do escorpionismo na região de Santarém, Estado do Pará, Brasil. Rev. Colombiana Cienc. Anim, v.4, n.1, p. 59-68, 2012.

COSTA,V.T; MEIRELLES, B.H.S; ERDMANN, A.L. Melhores práticas do enfermeiro gestor no gerenciamento de risco. Rev.Latino-Am.Enfermagem, v.21, n.5, [07 telas], 2013.

CRUZ, E. F. S. Biologia dos Escorpiões. In: BARRAVIERA, B. (Ed.). Venenos Animais Uma Visão Integrada. Rio de Janeiro: Editora de Publicações científicas. Ltda, 1994.

CUPO, P.; AZEVEDO-MARQUES, M. M.; HERING, S. E. Escorpionismo. In: CARDOSO, J.L.C.; FRANÇA, F. O. S.; WEN, F. H.; MÁLAQUE, C. M. S.; HADDAD, V. (Eds.), Animais Peçonhentos no Brasil: Biologia, Clínica e Terapêutica dos Acidentes. São Paulo: Sarvier, 2009.

CUPO, P. Clinical update on scorpion envenoming. Rev Soc Bras Med Trop, v.48, n.6, p.642$9,2015$.

DATASUS. Acidente por animais peçonhentos - Notificações registradas no Sistema de Informação de Agravos de Notificação - Sinan Net (2019), s/d. Disponível em: http://dtr2004.saude.gov.br/sinanweb/ Acesso em 15 de novembro de 2019. 
DÁVILA, C. A. M.; DÁVILA, D. F.; DONIS, J. H. Sympathetic nervous system activation, antivenin administration and cardiovascular manifestations of scorpion envenomation. Toxicon, v.40, p.1339-1346, 2002.

DE HARO, L.; POMMIER, P. Envenomation: a real risk of keeping exotic house pets. Vet. Hum. Toxicol, v.45, n.4, p.214-216, 2003.

DE-PAULA-SANTOS-DA-SILVA, A. et al. Some pharmacological effects of Tityus obscurus venom in rats and mice. Toxicon, v.126, p.51-58, 2017.

DE ROODT, A.R. et al. Epidemiological and clinical aspects of scorpionism by Tityus trivittatus in Argentina. Toxicon, v.41, p. 971-977, 2003.

DIAS, N.B. Profiling the short, linear, non-disulfide bond-containing peptidome from the venom of the scorpion Tityus obscurus. Journal of Proteomics, v.170, p.70-79, 2017.

ERWIN, T. L. Tropical forests: their richness in Coleoptera and other arthropod species. The Coleopterists Bulletin, v. 36, p.74-75,1982.

FORRESTER, M. B.; STANLEY, S. K. Epidemiology of scorpion envenomations in Texas. Vet. Hum. Toxicol, v.46, p. 219-221, 2004.

FREITAS, M. A. Guia Ilustrado dos Animais Venenosos e Peçonhentos no Brasil. Pelotas: USEB, 2011.

GAlvão, A. P.; RODRIGUES, D. Aspectos Clínicos e Epidemiológicos dos Acidentes Escorpiônicos no Município de Rurópolis, Pará. 2012. Monografia de Conclusão de Curso (Graduação em Enfermagem) - Universidade do Estado do Pará, Santarém.

GÓMEZ, J. et al. Picaduras por scorpión Tityus asthenes en Mutatá, Colombia: aspectos epidemiológicos, clínicos y toxinológios. Biomédica: Revista del Instituto Nacional de Salud, p.26-39, 2010.

GUERRERO-VARGAS, J. A. et al. Identification and Phylogenetic Analysis of Tityus pachyurus and Tityus obscurus Novel Putative Na+-Channel Scorpion Toxins. PLoS ONE, v.7, n.2, 2012.

GUIMARÃES, M. A. Vulnerabilidade subjetiva. In: SEMINÁRIO A VULNERABILIDADE DA POPULAÇÃO AFRO-BRASILEIRA Â EPIDEMIA DE HIV/AIDS, 2001, Rio de Janeiro.

IBGE. Instituto Brasileiro de Geografia e Estatística - 2017. Disponível em <http:// www.cidades.ibge.gov.br/historico. Acessado em 15 de julho de 2018.

IBGE. Instituto Brasileiro de Geografia e Estatística - 2015. Disponível em <http:// www.cidades.ibge.gov.br/historico. Acessado em 30 de agosto de 2017.

IBGE. Instituto Brasileiro de Geografia e Estatística. Censo 2010. Disponível em <http:// www.cidades.ibge.gov.br/historico. Acessado em 05 de dezembro de 2018. 
JAMI, S; ERICKSON, A; BRIERLEY, S.M; VETTER; I. Pain-Causing Venom Peptides: Insights into Sensory Neuron Pharmacology. Toxins, v. 10, n.15, 2018.

KHATTABI, A. et al. Classification of clinical consequences of scorpion stings: consensus development. Transactions of the Royal Society of Tropical Medicine and Hygiene, p.364, 2011.

LOURENÇO, W. R. Scorpiones. In: ADIS, J. (Org.). Amazonian arachnida and myriapoda: identification keys to all classes, orders, families, some genera and lists of known terrestrial species. Moscow: Pensoft Publishes, 2002.

LOURENÇO, W. R.; EICKSTEDT, V. R. D. Escorpiões de Importância Médica. In CARDOSO JLC et al. Animais Peçonhentos no Brasil. Biologia, Clínica e Terapêutica dos Acidentes. São Paulo: Sarvier, 2003.

MAESTRI NETO, A. et al. Aspectos do Escorpionismo no Estado do Pará-Brasil. Revista Paraense de Medicina, v.22, n.1, 2008.

MAGALHÃES, M. M. et al. Serum levels of cytokines in patientes envenomed by Tityus serrulatos scorpion sting. Toxicon, v.37, n.08, p.1155-64,1999.

MANN, J.; TARANTOLA, D.J.M.; NETTER, T.W. (Org). A AIDS no mundo: história social da AIDS. Rio de Janeiro: Relume Dumará, UERJ, 1993.

MATTHIESEN, F.A. Revisão sobre parasitas e predadores de escorpiões. Naturalia, v. 9, p. $1-5,1984$.

MCGHEE, S. et al. Assessing and managing spider and scorpion envenomation. Emergency Nurse, v.23, n.7, p.32-39, 2015.

MEGA, T.P. et al. Protocolos clínicos e diretrizes terapêuticas no SUS: histórico, desafios e perspectivas. Rev Eletrônica Gestão \& Saúde, v.6 (supl.4), p.3275-85, 2015.

MEJIAS, R. J. et al. Ocurrencia de escorpionismo en los distritos sanitarios de estado Merida,Venezuela. Invest Clin, p.48, 2007.

MEKI, A.R.; MOHAMED, Z.M.; MOHEY EL-DEEN, H.M. Significance of assessment of serum cardiac troponin I and interleukin-8 in scorpion envenomed children. Toxicon, v.4, n.2, p.129-37, 2003.

MENDES, A. A saúde no capitalismo financeirizado em crise: o financiamento do SUS em disputa. Centro de Estudos Estratégicos da FioCruz: futuro do Brasil, idéias para ação. FioCruz, 2017.

MUÑOZ-SANCHEZ, A.I; BERTOLOZZI, M.R. Pode o conceito de vulnerabilidade apoiar a construção do conhecimento em saúde coletiva? Ciência e Saúde Coletiva, v.12, n.2, p.319324, 2007.

MURGIA, A.R. et al. Amino acid sequence and function of a new alpha-toxin from the Amazonian scorpion Tityus cambridgeii. Toxicon, v.43, p.737-740, 2004. 
NAIK, B.S. "Dry bite” in venomous snakes: a review. Toxicon, v. 133, p.63-67, 2017.

NICHIATA, L.Y.I. et al. Utilização do conceito "vulnerabilidade" pela enfermagem. Rev. Latam Enfermagem, v. 16, n.5, 2008.

NICHIATA, L.Y.I. et al. Potencialidade do conceito de vulnerabilidade para compreensão das doenças transmissíveis. Rev. Esc Enf USP, v. 45, p. 1769-73, 2011.

NJAH, M. B. E. N. et al. Programmes de sante et recours aux agents de sante communautaire: l'exemple de l'envenimation scorpionique en Tunisie. Cahiers Sante, p. 57-62, 2001.

OLIVEIRA, S.M.S. Escorpionismo no interior da Amazônia: geoespacialização e aspectos clínico-epidemiológicos. 2018. Tese (Doutorado em Ciências) - Escola de Enfermagem, Universidade de São Paulo.

OSNAYA-ROMERO, N. et al. Clinical symptoms observed in children envenomed by scorpion stings, at the children's hospital from the state of Morelos, Mexico. Toxicon, v.39, n.6, p.781$5,2001$.

OTERO, R. et al. Scorpion envenoming in two regions of Colombia: clinical, epidemiological and therapeutic. Trans. R. Soc. Trop. Med. Hyg, p.742-750, 2004.

PADOVEZE, M.C; et al. O conceito de vulnerabilidade aplicado à Infecções Relacionadas à Assistência à Saúde. Rev Bras Enferm, v.72, n.1, p.311-6, 2019.

PARDAL, P. P. O. et al. Clinical aspects of envenomation caused by Tityus obscurus (Gervais, 1843) in two distinct regions of Pará state, Brazilian Amazon basin: a prospective case series. Journal of Venomous Animals and Toxins including Tropical Diseases, v.20, n.3, p.1-7, 2014.

PARDAL, P. P. O. et al. Aspectos epidemiológicos e clínicos do escorpionismo na região de Santarém, Estado do Pará, Brasil. Revista da Sociedade Brasileira de Medicina Tropical, v.36, n.3, p. 349-353, 2003.

PARDAL, P. P. O.; GADELHA, M. A. C. Acidentes por animais peçonhentos: manual de rotinas. Belém: SESPA -Secretaria de Estado de Saúde Pública do Pará, 2010.

PETRICEVICH, V.L. Scorpion venom and the inflammatory response. Mediat. Inflamm. Epub, 2010.

PINTO, L. R. et al. Tityus fasciolatus envenomation induced cardio-respiratory alterations in rats. Toxicon, v.55, n.6, p.1132-1137, 2010.

PIPELZADEH, M. H. An epidemiological and a clinical study on scorpionism by the Iranian scorpion Hemiscorpius lepturus. Toxicon, v. 50, p. 984-992, 2007.

POLIS, G. A (Org). The Biology of Scorpions. Stanford: Stanford University. Press. p. 587, 1990. 
POSSANI, L.D. et al. Scorpion toxin specific for Nap - channels. Eur. J. Biochem, v.264, p.287-300, 1999.

RECKZIEGEL, G. C. Análise do escorpionismo no Brasil no período de 2000 a 2010.2013. Dissertação (Mestrado em Saúde Coletiva) - Programa de Pós Graduação em Saúde Coletiva, Universidade de Brasília. Brasília.

RECKZIEGEL, G. C.; JUNIOR, V. L. P. Análise do escorpionismo no Brasil no período de 2000 a 2010. Rev Pan-Amaz Saude, v.5, n.1, p.67-68, 2014.

RENTERIA, M.A.S; ESPINOSA, R.R. Investigaciones socioambientales, educativas y humanísticas para el médio rural. Universidad de Málaga. España, 2017.

RIBEIRO, L. A.; RODRIGUES, L.; JORGE, M. T. Aspectos clínicos e epidemiológicos do envenenamento por escorpiões em São Paulo e municípios próximos. Rev Patol Trop, v.30, n.1, p.83-92, 2001.

ROCHA, P.R; DAVID, H.M.S. Determinação ou determinantes? Uma discussão com base na Teoria da Produção da Saúde. Rev. Esc Enf, v. 49. n. 1, p. 129-135, 2015.

ROOT, T. M. Neurobiology. In: POLIS, G. A. (Org.). The biology of scorpions. Stanford: Stanford University Press, p. 341-413. 1990.

SANCHEZ, A.I.M; BERTOLOZZI, M.R. Pode o conceito de vulnerabilidade apoiar a construção do conhecimento em Saúde Coletiva? Ciência e Saúde Coletiva, v.12, n.2, p.319324, 2007.

SCHENONE, H.; FONTECILLA, J. Brotes epidemicos de picaduras de escorpion en habitantes de viviendas urbanas de construccion reciente. Bol. Chil. Parasitol, p.35-37, 1998.

SIEGAL, T; LOSSOS, A. Electric shock-like sensations in 42 cancer patients: clinical characteristics and distinct etiologies. Journal of Neuro-Oncology, v. 29, p.175-181, 1996.

SILVA, A.J.S. et al. Implication of Tityus apiacas (Lourenco, 2002) in scorpion envenomations in the Southern Amazon border, Brasil. Rev Soc Bras Med Trop, v.50, n.3, p.427-430, 2017.

SIMON, R.B Managing scorpion envenomation in children. Nursing, p.13-15, 2015.

SISSOM, W. D. Systematics, biogeography and paleontology. In: POLIS, G. A. (Org.). The biology of scorpions. Stanford: Stanford University Press, p. 64-160. 1990.

SOLEGLAND, M. E.; FET, V. High level systematics and phylogeny of the extant scorpions (Scorpiones: Orthosterni). Euscorpius, n.11, p. 1-175, 2003.

SOULAYMANI-BENCHEIKH, R. et al. Epidemiologie des piqures de scorpion au Maroc. Rev. Epidemiol. Santé Publique, v. 50, p.341-347, 2002.

TORREZ, P. P. Q. Estudo clínico-epidemiológico, laboratorial e de vulnerabilidades dos acidentes escorpiônicos atendidos no Hospital Municipal de Santarém - PA. 2016. Tese 
(Doutorado em Doenças Infecciosas e Parasitárias) - Faculdade de Medicina, Universidade de São Paulo, 2016.

TORREZ, P. P. Q. et al. Acute cerebellar dysfunction with neuromuscular manifestations after scorpionism presumably caused by Tityus obscurus in Santarém, Pará/ Brazil. Toxicon, v. 96, p.68-73, 2015.

TORREZ, P. P. Q. et al. Scorpionism in Brazil: exponential growth of acidentes and deaths from scorpion stings. Rev. Soc.Bras Med Trop, v. 52, e 20180350, 2019.

UTKIN, Y.N. Animal venom studies: current benefits and future development. World J Biol Chem, v.6, n.2, p. 28-33, 2015.

VASCONCELOS, F. et al. Effects of voltage-gated $\mathrm{Na}+$ channel toxins from Tityus serrulatus venom on rat arterial blood pressure and plasma catecholamines. Comp. Biochem. Physiol. C Toxicol. Pharmacol, v.141, n.1, p.85-92, 2005.

VAZIRIANZADEH, B. et al. An epidemiological and clinical study on scorpionism in hospitalized children in Khuzestan. J. Arthrop-Borne Dis. Iran, v.6, p.62-69, 2012.

VIANA, N.S; SOARES, C.B; CAMPOS, C.M.S. Reprodução social e processo saúde-doença: para compreender o objeto da saúde coletiva. In: SOARES, C.B; CAMPOS, C.M.S, organizadores. Fundamentos de saúde coletiva e o cuidado de enfermagem. Barueri: Manole; 2013. p. 107-42. 11. 
APÊNDICES 


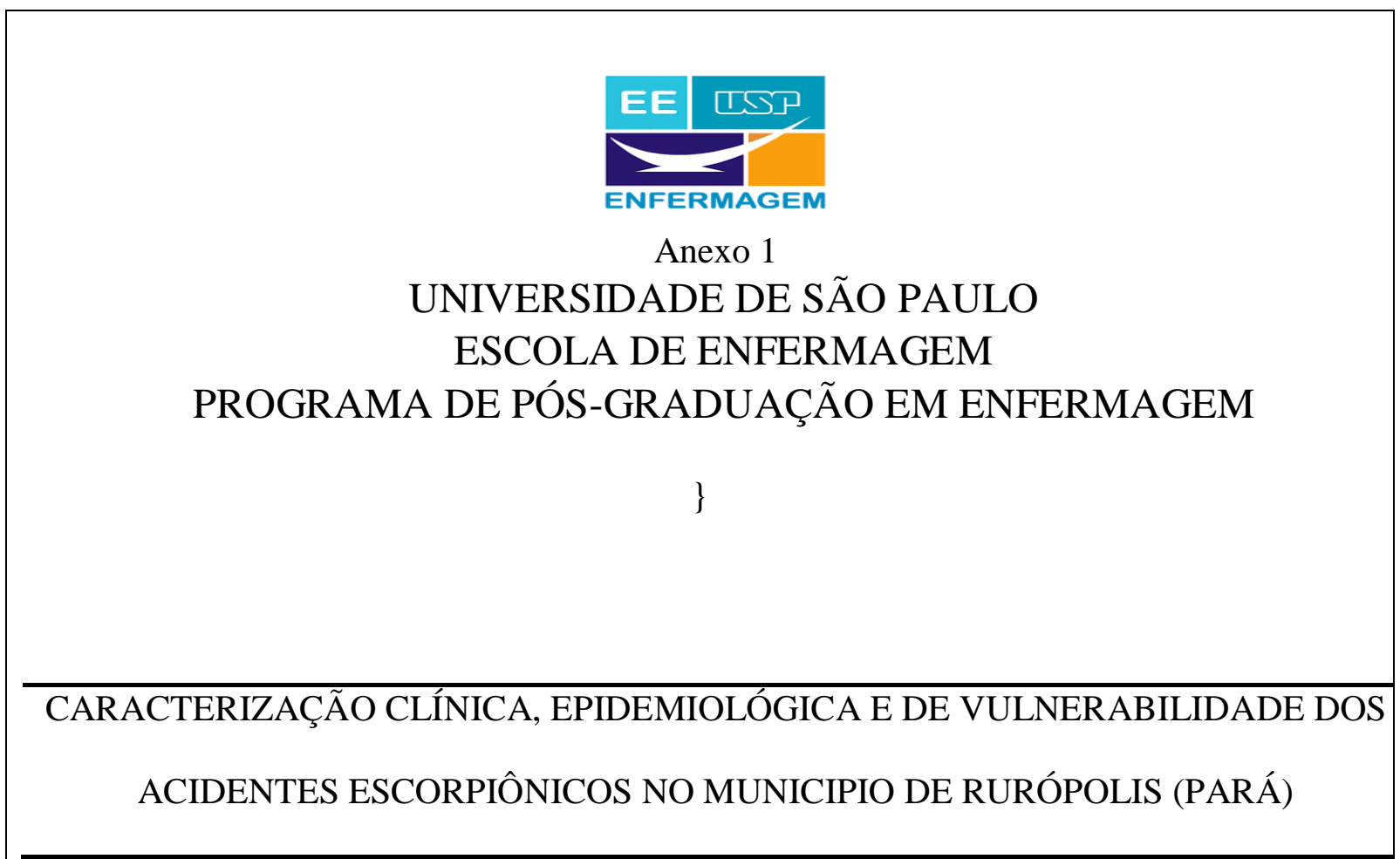

Questionário de Pesquisa

Este questionário que o senhor (a) irá responder faz parte de uma pesquisa que está sendo desenvolvida no Hospital Municipal de Rurópolis com objetivo de conhecer os aspectos clínicos e epidemiológicos, nos diferentes padrões de gravidade, dos acidentes escorpiônicos do município de Rurópolis, Pará.

Assinale com $\mathrm{X}$ a alternativa que corresponde a sua resposta. Garantimos que o senhor (a) não será identificado (a) e suas respostas serão secretas e somente o resultado geral da pesquisa será divulgado.

Coordenação de Pesquisa

Pesquisadora / Orientadora: Prof. Dra. Lucia Yasuko Izumi Nichiata.

Pesquisador/Coorientador: Prof. Dr. Francisco Oscar França

Pesquisadora/ Enfermeira: Fernanda Jacqueline Teixeira Cardoso. 


\begin{tabular}{|c|}
\hline 1. Número de Identificação: __ _ \\
\hline I- ASPECTOS SOCIOECONÔMICOS E DEMOGRÁFICOS. \\
\hline 4. Nome: \\
\hline 6. Sexo: 1( ) Masculino ( ) Feminino \\
\hline 7. Qual sua cor/ raça?: 1() Branca 2( ) Negra 3( ) Parda 4( ) outros \\
\hline 2( ) Fundamental incompleto 3( ) Fundamental completo \\
\hline 4( ) Médio incompleto 5( ) Médio incompleto 6() Superior incompleto 7() Superior completo \\
\hline 9. Estado civil: 1()Solteiro 2( ) Casado 3( )União estável 4( )Divorciado/separado 5( )viúvo: \\
\hline 10. Qual sua crença religiosa? \\
\hline 11. Quantas pessoas moram com você ? $1($ ) 2 a 5 2( ) 6 a 10 3( ) 11 a 15 \\
\hline 12. Renda familiar (em salário mínimo): 1( )2 a 3 2( ) 3 a $4 \quad$ 3( ) acima de 4 \\
\hline 14. Formal: 1( ) sim \\
\hline 15. Endereço: \\
\hline 17. Zona: 1 ( )urbana 2( ) rural 3 ( ) periurbana \\
\hline 18. Sua casa é constituída de: 1 ( ) Alvenaria 2( ) Madeira 3( ) Barro 4( ) outros \\
\hline 19. Sua casa possui: água encanada 1 ( ) sim 2 ( ) não 20. Quantos cômodos? \\
\hline Na sua comunidade há: 21.Coleta de lixo: 1 ( ) sim 2 ( ) não 22. Saneamento básico: 1( ) sim 2( ) não \\
\hline 23. Se não, destino dos dejetos: \\
\hline II - PERFIL DE SAÚDE \\
\hline 27.Alergias:1( )sim \\
\hline 28. Etilismo: 1( )sim 2( )não 29. Tabagismo: 1( )sim 2( ) não 30.Quantos ao dia? \\
\hline 31. Antecedentes mórbidos: ( ) HAS ( ) DM ( )Doença Renal ( )Epilepsia ( )Parkinson ( )hepatopatia \\
\hline ( ) Doenças neuromusculares ( ) outros Especificar: \\
\hline 32. Faz uso de medicamentos? Quais \\
\hline 33. Já foi picado por escorpião? 1 ( )sim 2 ( ) não 34. Se sim, quando? \\
\hline 35. Qual era a cor do animal? \\
\hline III- ACIDENTE ESCORPIÔNICO \\
\hline 38. Data do Acidente ___ ___ __ 39. Data da Internação ___ ___ \\
\hline 42. Hora do Início dos Sintomas: \\
\hline 43. Local da picada: 1( ) MMSS 2( ) MMII 3( )Tronco 4( )Cabeça 5( ) outros (especificar): \\
\hline 44. Local do acidente: 1( ) domicílio 2( ) peridomicílio 3( ) área rural 4 ( )via pública 5( ) outr \\
\hline 45. Situação geradora do acidente: 1 ( ) lazer 2 ( ) repouso $3($ ) trabalho $4($ ) tarefas cotidianas \\
\hline 5() outras Especificar \\
\hline 46. Nome do animal: \\
\hline 48. Trouxe o animal?1()sim 2( )não $49 . \mathrm{N}^{\circ}$ identificação: \\
\hline 51. Cuidados realizados antes da internação hospitalar: \\
\hline $\begin{array}{l}\text { 52. Manifestações locais: 1- sim 2- não ( ) dor ( ) edema ( ) eritema ( ) necrose ( ) calor local } \\
\text { ( ) piloereção () sudorese () parestesia ( ) choque elétrico ( ) outros Especificar: }\end{array}$ \\
\hline $\begin{array}{l}\text { 53. Manifestações Sistêmicas: } 1 \text { - sim } 2 \text { - não ( ) Hipertensão ( ) Hipotensão ( ) Sudorese ( ) Náuseas ( } \\
\text { ) Vômitos ( ) Sialorreia ( ) Diarréia ( ) Priaprismo ( ) Oligúria ( ) Anúria ( ) Taquicardia ( ) Arritmia } \\
\text { Cardíaca ( ) Bradicardia ( ) Dismetria ( ) Disartria ( ) Ataxia de marcha ( ) Mioclonia ( ) Fasciculação } \\
\text { ( ) Astenia ( ) Disfagia ( ) Tremores ( ) Hipertermia }\end{array}$ \\
\hline
\end{tabular}


54. Se sensação de choque elétrico, quanto tempo após a picada ela iniciou?

55. Quanto tempo depois a picada ele desapareceu?

56. Em que partes do corpo você sentiu esse choque? 1- sim 2- não (marcar CE no boneco abaixo)

( ) somente no local da picada ( ) No membro afetado ( ) no lado do corpo afetado ( ) Em todo corpo

57. Se em corpo todo, como foi a evolução do choque? Foi crescente ou imediata?

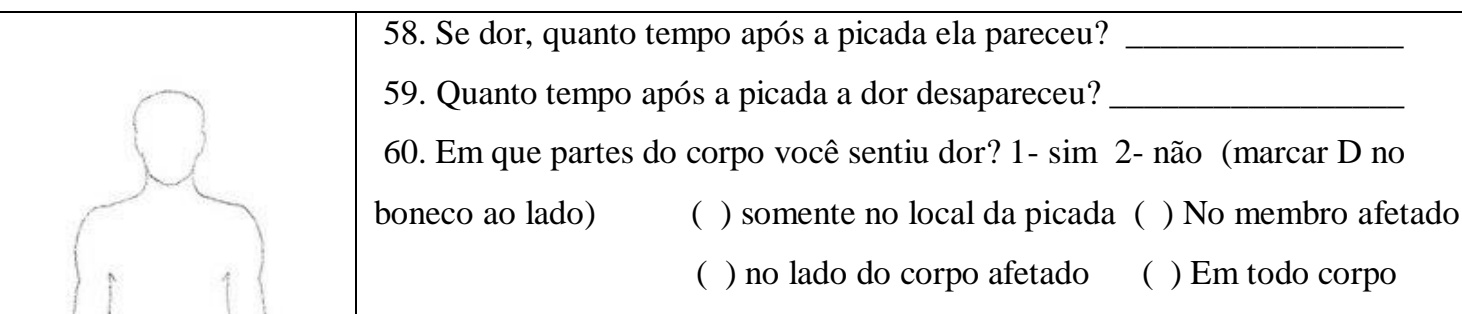

61. Se dor no corpo, como foi a evolução? Foi crescente ou imediata?

62. Qual score você atribui ao início da dor?

63. Se parestesia, quanto tempo após a picada ela pareceu?

64. Quanto tempo após a picada a parestesia desapareceu?

65. Em que partes do corpo você sentiu parestesia? 1- sim 2- não (marcar P

no boneco ao lado) ( ) somente no local da picada

( ) No membro afetado ( ) no lado do corpo afetado ( ) Em todo corpo

66. Se parestesia no corpo todo, como foi a evolução? Foi crescente ou imediata?

67. Se mioclonia, quanto tempo após a picada ela iniciou?

68. Quanto tempo depois a picada ela desapareceu?

69. Em que partes do corpo você sentiu essa mioclonia? 1- sim 2- não (marcar M no boneco abaixo)

( ) somente no local da picada ( ) No membro afetado ( ) no lado do corpo afetado ( ) Em todo corpo

70. Se em corpo todo, como foi a evolução da mioclonia? Foi crescente ou imediata?

71. Se disartria, dismetria e ataxia de marcha, quanto tempo após a picada esses sintomas iniciaram ou foram registrados?

72. Quanto tempo depois a picada eles desapareceram?

73. Se alterações urinárias, quanto tempo após a picada eles iniciaram?

74. Quais sintomas foram encontrados?

75. Quanto tempo depois a picada eles desapareceram?

\begin{tabular}{|c|c|c|}
\hline \multicolumn{3}{|c|}{ IV- ASSISTÊNCIA À PESSOA VÍTIMA DO ESCORPIONISMO } \\
\hline Sinais Vitais & 76. Temperatura _ & 78. FR 79. FC \\
\hline \multicolumn{3}{|c|}{ 81. Escala de Glasgow __ 81. ACP: } \\
\hline \multicolumn{3}{|c|}{ Exames Complementares na Admissão Hospitalar } \\
\hline 82. ECG & 1( ) R 2( ) NR Data / / Hora & Resultado: \\
\hline 83. EMG & 1( ) R 2( ) NR & Resultado: \\
\hline 84. Hemograma & Data // Hora & Resultado: \\
\hline 85. CPK & 1( ) R 2( ) NR Data // Hora & Resultado: \\
\hline 86. CPK MB & 1( ) R 2( ) NR Data // Hora & Resultado: \\
\hline 87. TGO & 1( ) R 2( ) NR Data // Hora & Resultado: \\
\hline 88. TGP & 1( ) R 2( ) NR & Resultado: \\
\hline 89. Uréia & Data / / Hora & Resultado: \\
\hline
\end{tabular}




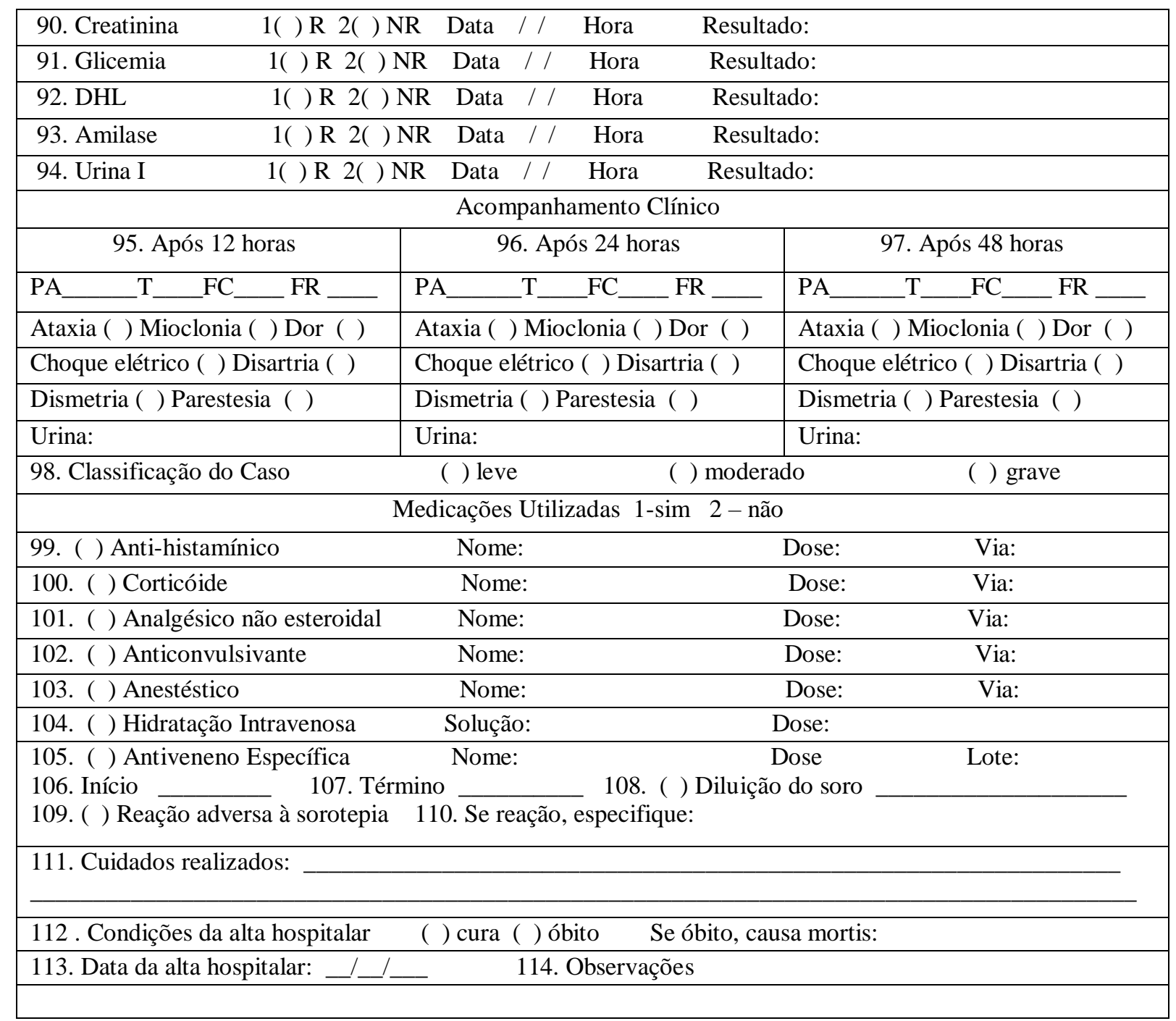


APÊNDICE II

ROTEIRO DA ENTREVISTA

Identificação:

Data: ____

Paciente ( ) Responsável ( )

1. O que você sabe sobre acidente escorpiônico?

2. Como você denomina o animal que lhe picou? Qual a sua cor?

3. Você sabe porque ele o picou? É comum ele estar presente no local onde aconteceu o acidente?

4. Você já tinha sofrido esse tipo de acidente? Se sim, há quanto tempo, qual a cor do animal e o que sentiu?

5. Você realizou algum cuidado com o local da picada antes de ir para o Hospital? Qual? Porque realizou e quem o (a) ensinou este cuidado?

6. Você já tinha tido acesso à informações sobre o acidente escorpiônico na comunidade? (palestras, escolas, ACS)

7. Você conhece outras pessoas na comunidade que já sofreram acidente escorpiônico?

8. A que você atribui a existência desse tipo de acidente?

9. Se você já foi picado, por que você acha que foi picado novamente?

10. Existe alguma organização na comunidade para situações como esta? O que fazem e como se organizam?

11. Você participa de alguma organização que debatem os direitos de cidadão?

12. Você sabe o que é o SUS? Como você percebe a rede pública de saúde no Município?

13. Como você avalia o acesso (como chegar) aos serviços de saúde do município de Rurópolis?

14. Como você avalia a acessibilidade (como entrar) aos serviços de saúde do município de Rurópolis?

15. Como você avalia a qualidade da assistência ao paciente vítima de escorpionismo no Hospital Municipal de Rurópolis?

16. Quais as dificuldades que você sentiu durante todo o processo de vivência do acidente escorpiônico?

17. Quais as facilidades (se houve) que você sentiu durante todo o processo de vivência do acidente escorpiônico?

18. O que você acha que os profissionais de saúde poderiam fazer para melhorar o atendimento para pessoa que foi picada por escorpião?

19. O que você acha que deve ser feito para outras pessoas não sofram acidente com escorpião?

20. Que medida você acredita que ajudaria a evitar esses acidentes? 


\section{APÊNDICE III}

\section{TERMO DE CONSENTIMENTO LIVRE E ESCLARECIDO (TCLE)}

Título: Caracterização Clínica, Epidemiológica e de Vulnerabilidade dos Acidentes Escorpiônicos em Rurópolis, Pará.

Convidamos o (a) senhor(a) a participar como voluntário(a) na pesquisa chamada "CARACTERIZAÇÃO CLÍNICA, EPIDEMIOLÓGICA E DE VULNERABILIDADE DOS ACIDENTES ESCORPIÔNICOS EM RURÓPOLIS- PARÁ”. Caso concorde, o(a) Senhor (a) deverá assinar (escrever seu nome completo) em duas vias deste formulário para que uma seja sua.

Este estudo apresenta um tema ligado à acidentes escorpiônicos ocorridos no município de Rurópolis e busca Estudar os aspectos epidemiológicos (quantos acidentes ocorrem, onde mais ocorrem), clínicos (sinais e sintomas) e de vulnerabilidade (susceptibilidade) dos acidentes escorpiônicos ocorridos no município de Rurópolis, oeste paraense. Para então podermos: Analisar a vulnerabilidade ao acidente escorpiônico no município de Rurópolis, Pará, Brasil, de forma a identificar a vulnerabilidade individual (conhecimento e comportamentos/atitudes referidos ao agravo, aspectos sociodemográficos, clínicos e epidemiológicos dos acidentes) e identificar contextos de vulnerabilidade coletiva do escorpionismo em Rurópolis.

Ao aceitar participar da pesquisa o (a) Senhor (a) estará permitindo que os dados do seu prontuário sejam utilizados afim de contribuir para este estudo e aceitando participar de uma entrevista, sobre suas condições sociais, econômicas, de moradia e quais as sobre as sensações durante as manifestações clinicas, bem como a intensidade, surgimento, localização e cessação das mesmas, com duração de média de 30 minutos realizada em momento oportuno ou na Sala de Enfermagem antes da alta hospitalar.

Asseguramos o total sigilo de todos os dados coletados. Suas informações pessoais como seu nome, por exemplo, não serão reveladas. O trabalho será realizado com os recursos próprios dos pesquisadores, portanto, o (a) Senhor (a) não terá despesas financeiras em nenhuma fase do estudo, assim como, não haverá nenhum pagamento por sua participação. Não haverá riscos diretos. Os dados obtidos servirão para a compor uma tese de doutorado e, todos os dados serão arquivados por cinco anos, após esse período serão incinerados (queimados), conforme orientação da Resolução do Conselho Nacional de Saúde 466/2012.

O (a) Senhor (a) como participante (voluntário) terá o direito de retirar sua permissão a qualquer momento, sem quaisquer prejuízos. Este estudo contribuirá para verificar quais os aspectos clínicos e epidemiologia dos acidentes escorpiônicos no município de Rurópolis, para conhecer e descrever de maneira mais detalhada as peculiaridades dos acidentes ocorridos nessa região.

O estudo está sob a orientação da Prof ${ }^{a}$. Dra. Lucia Yasuko Izumi Nichiata e coorientação do Dr Francisco Oscar de Siqueira França. A pesquisadora responsável é Fernanda Jacqueline Teixeira Cardoso, RG 3376369-PC/PA, CPF 713.077.292-15, residente e domiciliada à rua Governador Mário Covas, 440, Centro, Rurópolis, Pará e pode ser contactada no telefone (93) 991527325.

O projeto foi apreciado e aprovado pelo Comitê de Ética em Pesquisa da Universidade do Estado do Pará- Campus XII, localizado à AV: Plácido de Castro, nº 1399 Bairro Aparecida - Telefone: (093) - (3512-8000).

Declaro que compreendi as informações do que li e que me foram explicadas sobre o estudo em questão. Discuti com os pesquisadores sobre a decisão de permitir que as informações sejam levantadas para o estudo, ficando claro, quais são os propósitos da pesquisa, os procedimentos a serem realizados, os possíveis desconfortos e riscos, as garantias de 
confidencialidades e de esclarecimentos permanentes. Ficou claro também que a minha participação não será paga, não haverá despesas, inclusive se optar por desistir de fornecer as informações.

Rurópolis - Pará, de 2016.

Assinatura do Participante da Pesquisa

Fernanda Jacqueline Teixeira Cardoso

Declaro que obtive de forma apropriada e voluntária o consentimento livre e esclarecido do presente participante do estudo.

Fernanda Jacqueline Teixeira Cardoso

Pesquisadora responsável. 


\section{APÊNDICE IV}

\section{TERMO DE CONSENTIMENTO LIVRE E ESCLARECIDO (TCLE) - PARTICIPANTES MENORES DE IDADE}

Título: Caracterização Clínica, Epidemiológica e de Vulnerabilidade dos Acidentes Escorpiônicos em Rurópolis, Pará.
Convidamos
(a) senhor
(a) a
autorizar
a participação
do menor

como

voluntário (a) na pesquisa chamada "CARACTERIZAÇÃO CLÍNICA, EPIDEMIOLÓGICA E DE VULNERABILIDADE DOS ACIDENTES ESCORPIÔNICOS EM RURÓPOLISPARÁ". Caso concorde, o (a) Senhor (a) deverá assinar (escrever seu nome completo) em duas vias deste formulário para que uma seja sua.

Este estudo apresenta um tema ligado a acidentes escorpiônicos ocorridos no município de Rurópolis e busca estudar os aspectos epidemiológicos (quantos acidentes ocorrem, onde mais ocorrem), clínicos (sinais e sintomas) e de vulnerabilidade (susceptibilidade) dos acidentes escorpiônicos ocorridos no município de Rurópolis, oeste paraense. Para então podermos: Analisar a vulnerabilidade ao acidente escorpiônico no município de Rurópolis, Pará, Brasil, de forma a identificar a vulnerabilidade individual (conhecimento e comportamentos/atitudes referidos ao agravo, aspectos sociodemográficos, clínicos e epidemiológicos dos acidentes) e identificar contextos de vulnerabilidade coletiva do escorpionismo em Rurópolis.

Ao aceitar contribuir com pesquisa o (a) Senhor (a) estará permitindo que os dados do prontuário do menor sob sua responsabilidade sejam utilizados afim de contribuir para este estudo e autorizando a participação do menor ou sua como representante em uma entrevista, sobre quais as sobre as condições sociais, econômicas, de moradia e as sensações durante as manifestações clinicas, bem como a intensidade, surgimento, localização e cessação das mesmas, com duração de cerca de 30 minutos realizada em momento oportuno ou na Sala de Enfermagem antes da alta hospitalar.

Asseguramos o total sigilo de todos os dados coletados. As informações pessoais do participante como seu nome, por exemplo, não serão reveladas. O trabalho será realizado com os recursos próprios dos pesquisadores, portanto, o (a) Senhor (a) não terá despesas financeiras em nenhuma fase do estudo, assim como, não haverá nenhum pagamento pela participação na pesquisa. Não haverá riscos diretos. Os dados obtidos servirão para a produção de um trabalho de conclusão de curso e, todos os dados serão arquivados por cinco anos, após esse período serão incinerados (queimados), conforme orientação da Resolução do Conselho Nacional de Saúde 466/2012.

O (A) Senhor (a) como responsável pelo menor terá o direito de retirar sua permissão a qualquer momento, sem quaisquer prejuízos. Este estudo contribuirá para verificar quais os aspectos clínicos e epidemiologia dos acidentes escorpiônicos no município de Rurópolis, para conhecer e descrever de maneira mais detalhada as peculiaridades dos acidentes ocorridos nessa região.

O estudo está sob a orientação da Prof ${ }^{a}$. Dra. Lucia Yasuko Izumi Nichiata e coorientação do Dr Francisco Oscar de Siqueira França. A pesquisadora responsável é Fernanda Jacqueline Teixeira Cardoso, RG 3376369-PC/PA, CPF 713.077.292-15, residente e domiciliada à rua Governador Mário Covas, 440, Centro, Rurópolis, Pará e pode ser contactada no telefone (93) 991527325.

O projeto foi apreciado e aprovado pelo Comitê de Ética em Pesquisa da Universidade do Estado do Pará- Campus XII, localizado à AV: Plácido de Castro, nº 1399 Bairro Aparecida - Telefone: (093) - (3512-8000). 
Declaro que compreendi as informações do que li e que me foram explicadas sobre o estudo em questão. Discuti com os pesquisadores sobre a decisão de permitir que as informações sejam levantadas para o estudo, ficando claro, quais são os propósitos da pesquisa, os procedimentos a serem realizados, os possíveis desconfortos e riscos, as garantias de confidencialidades e de esclarecimentos permanentes. Ficou claro também que a participação na pesquisa não será paga, não haverá despesas, inclusive se optar por desistir de fornecer as informações.

$$
\text { Rurópolis - Pará, __ de } 2016 .
$$

Nome do Participante:

Assinatura do responsável:

Fernanda Jacqueline Teixeira Cardoso

Declaro que obtive de forma apropriada e voluntária o consentimento livre e esclarecido do responsável do presente participante do estudo.

Prof $^{a}$. Me. Fernanda Jacqueline Teixeira Cardoso

Pesquisadora responsável. 


\section{APÊNDICE V}

Termo de Assentimento do Menor

Você está sendo convidado para participar da pesquisa "CARACTERIZAÇÃO CLÍNICA, EPIDEMIOLÓGICA E DE VULNERABILIDADE DOS ACIDENTES ESCORPIÔNICOS EM RURÓPOLIS- PARÁ”. Seus pais permitiram que você participe.

Queremos saber quais os aspectos epidemiológicos (quantos acidentes ocorrem, onde mais ocorrem), clínicos (sinais e sintomas) e de vulnerabilidade (susceptibilidade) dos acidentes escorpiônicos ocorridos no município de Rurópolis, oeste paraense. Para então podermos: Analisar a vulnerabilidade ao acidente escorpiônico no município de Rurópolis, Pará, Brasil, de forma a identificar a vulnerabilidade individual (conhecimento e comportamentos/atitudes referidos ao agravo, aspectos sociodemográficos, clínicos e epidemiológicos dos acidentes) e identificar contextos de vulnerabilidade coletiva do escorpionismo em Rurópolis.

As crianças que irão participar dessa pesquisa têm de sete anos de idade e adolescentes menores de 18 anos. Você não precisa participar da pesquisa se não quiser, é um direito seu, não terá nenhum problema se desistir.

A pesquisa será feita no Hospital Municipal de Rurópolis, onde as crianças e adolescentes participarão de uma entrevista, que será gravada com perguntas preestabelecidas que será realizada na Sala de Enfermagem. Ao aceitar participar da pesquisa, você estará permitindo que os dados do seu prontuário sejam utilizados a fim de contribuir para este estudo. Você não sofrerá nada de ruim por causa da pesquisa. E ao aceitar você estará contribuindo para uma melhor compreensão dos aspectos clínicos e epidemiológicos do escorpionismo no Município de Rurópolis no período de outubro de 2016 a outubro de 2017.

Ninguém saberá que você está participando da pesquisa, não falaremos a outras pessoas, nem daremos a estranhos as informações que você nos der. Os resultados da pesquisa vão ser publicados, mas sem identificar as crianças que participaram da pesquisa.

Se você tiver alguma dúvida, você pode perguntas à pesquisadora responsável Fernanda Jacqueline Teixeira Cardoso, RG 3376369-PC/PA, CPF 713.077.292-15, residente e domiciliada à rua Governador Mário Covas, 440, Centro, Rurópolis, Pará e pode ser contactada no telefone (93) 991527325.

O projeto foi apreciado e aprovado pelo Comitê de Ética em Pesquisa da Universidade do Estado do Pará- Campus XII, localizado à AV: Plácido de Castro, nº 1399 Bairro Aparecida - Telefone: (093) - (3512-8000).

$\mathrm{Eu}$ aceito participar da pesquisa "CARACTERIZAÇÃO CLÍNICA, EPIDEMIOLÓGICA E DE VULNERABILIDADE DOS ACIDENTES ESCORPIÔNICOS EM RURÓPOLIS- PARÁ" que tem o objetivo de saber quais os aspectos epidemiológicos (quantos acidentes acontecem), clínicos (sinais e sintomas) e de vulnerabilidade dos acidentes escorpiônicos ocorridos no município de Rurópolis, oeste paraense. Entendi as coisas ruins e as coisas boas que podem acontecer. Entendi que posso dizer "sim" e participar, mas que, a qualquer momento, posso dizer "não" e desistir que ninguém vai ficar furioso.

Os pesquisadores tiraram minhas dúvidas e conversaram com os meus responsáveis. Recebi uma cópia deste termo de assentimento e li e concordo em participar da pesquisa.

Rurópolis, de de 2016. 
Fernanda Jacqueline Teixeira Cardoso 


\section{APÊNDICE VI}

\section{TERMO DE CONSENTIMENTO DE USO DE DADOS - TCUD}

Fernanda Jacqueline Teixeira Cardoso - CPF 713.077.292-15

Realizarei a pesquisa, que tem como o tema: "CARACTERIZAÇÃO CLÍNICA, EPIDEMIOLÓGICA E DE VULNERABILIDADE DOS ACIDENTES ESCORPIÔNICOS EM RURÓPOLIS- PARÁ”. Neste estudo, pretendemos

O motivo que nos leva a realizar esta pesquisa é o interesse em verificar quais os os aspectos epidemiológicos (quantos acidentes ocorrem, onde mais ocorrem), clínicos (sinais e sintomas) e de vulnerabilidade (susceptibilidade) dos acidentes escorpiônicos ocorridos no município de Rurópolis, oeste paraense. Para então podermos: Analisar a vulnerabilidade ao acidente escorpiônico no município de Rurópolis, Pará, Brasil, de forma a identificar a vulnerabilidade individual (conhecimento e comportamentos/atitudes referidos ao agravo, aspectos sociodemográficos, clínicos e epidemiológicos dos acidentes) e identificar contextos de vulnerabilidade coletiva do escorpionismo em Rurópolis.

O estudo está sob a orientação da Prof ${ }^{a}$. Dra. Lucia Yasuko Izumi Nichiata e coorientação do Prof. Dr. Francisco Oscar de Siqueira França, da Universidade de São Paulo.

O presente estudo terá como produto uma Tese de Doutorado da discente e pesquisadora Fernanda Jacqueline Teixeira Cardoso, RG 3376369-PC/PA, CPF 713.077.292-15, residente e domiciliada à rua Governador Mário Covas, 440, Centro, Rurópolis, Pará e pode ser contactada no telefone (93) 991527325.

Para este estudo analisaremos os dados dos prontuários dos pacientes que forem atendidos no Hospital Municipal de Rurópolis, vítimas de acidente escorpiônico, no período de outubro de 2016 a março de 2017 onde serão verificados dados sociodemográficos, epidemiológicos, dados clínicos, tratamento e conclusão do caso.

O projeto foi apreciado e aprovado pelo Comitê de Ética em Pesquisa da Universidade do Estado do Pará- Campus XII, localizado à AV: Plácido de Castro, nº 1399 Bairro Aparecida - Telefone: (093) - (3512-8000).

Declaração:

Nós, membros do grupo de pesquisa identificado acima, baseados nos itens III.3.i e III.3.t das Diretrizes e Normas Regulamentadoras de Pesquisas Envolvendo Seres Humanos (Res CNS 466/12) e na Diretriz 12 das Diretrizes Éticas Internacionais para Pesquisas Biomédicas Envolvendo Seres Humanos (CIOMS/93), declaramos que:

a) $\mathrm{O}$ acesso aos dados registrados nas fichas de notificação será para fins da pesquisa científica e será feito somente com aprovação do projeto de pesquisa pelo CEP-UEPA;

b) O acesso aos dados será supervisionado por uma pessoa que esteja plenamente informada sobre as exigências de confiabilidade;

c) Asseguraremos o compromisso com a privacidade e a confidencialidade dos dados utilizados, preservando integralmente o anonimato e a imagem do sujeito bem como a sua nãoestigmatização;

d) Asseguraremos a não-utilização das informações em prejuízo das pessoas e/ou das comunidades, inclusive em termos de autoestima, de prestígio e/ou econômico-financeiro;

e) O pesquisador responsável estabeleceu salvaguardas seguras para a confidencialidade dos dados de pesquisa. Os sujeitos envolvidos serão informados dos limites da habilidade do 
pesquisador em salvaguardar a confidencialidade e das possíveis consequências da quebra de confidencialidade, caso seja necessário;

f) Os dados obtidos na pesquisa serão usados exclusivamente para a finalidade prevista no protocolo;

g) Os dados obtidos na pesquisa somente serão utilizados para o projeto vinculado. Todo e qualquer outro uso que venha a ser planejado, será objeto de novo projeto de pesquisa, que será submetido à apreciação do CEP-UEPA;

h) Devido à impossibilidade de obtenção do Termo de Consentimento Livre e Esclarecido de todos os sujeitos, assinaremos esse Termo de Consentimento de Uso de Banco de Dados, para a salvaguarda de seus direitos.

Este termo de consentimento encontra-se impresso em duas vias, sendo que uma cópia será arquivada pelo pesquisador responsável, na Universidade do Estado do Pará e a outra será fornecida a você. Caso haja danos decorrentes dos riscos previstos, o pesquisador assumirá a responsabilidade pelos mesmos.

$\mathrm{Eu}$, fui informado dos objetivos do estudo "Caracterização Clínica, Epidemiológica e de Vulnerabilidade dos Acidentes Escorpiônicos em Rurópolis- Pará”, de maneira clara e detalhada e esclareci minhas dúvidas. Sei que a qualquer momento poderei solicitar novas informações e modificar minha decisão de fornecer o acesso aos dados dos prontuários, referente aos acidentes escorpiônicos, se assim o desejar.

Declaro que concordo em participar desse estudo. Recebi uma cópia deste termo de consentimento de uso de dados e me foi dada à oportunidade de ler e esclarecer as minhas dúvidas.

Rurópolis, __ de_ de 2016.

Assinatura do participante

Prof $^{a}$. Me. Fernanda Jacqueline Teixeira Cardoso 
ANEXO I

Ficha do SINAN

República Federativa do Brasil
Ministério da Saúde

SINAN

SISTEMA DE INFORMAČ̃̃ DE AGRAVOS DE NOTIFICAÇĀO

No

ACIDENTES POR ANIMAIS PECONHENTOS

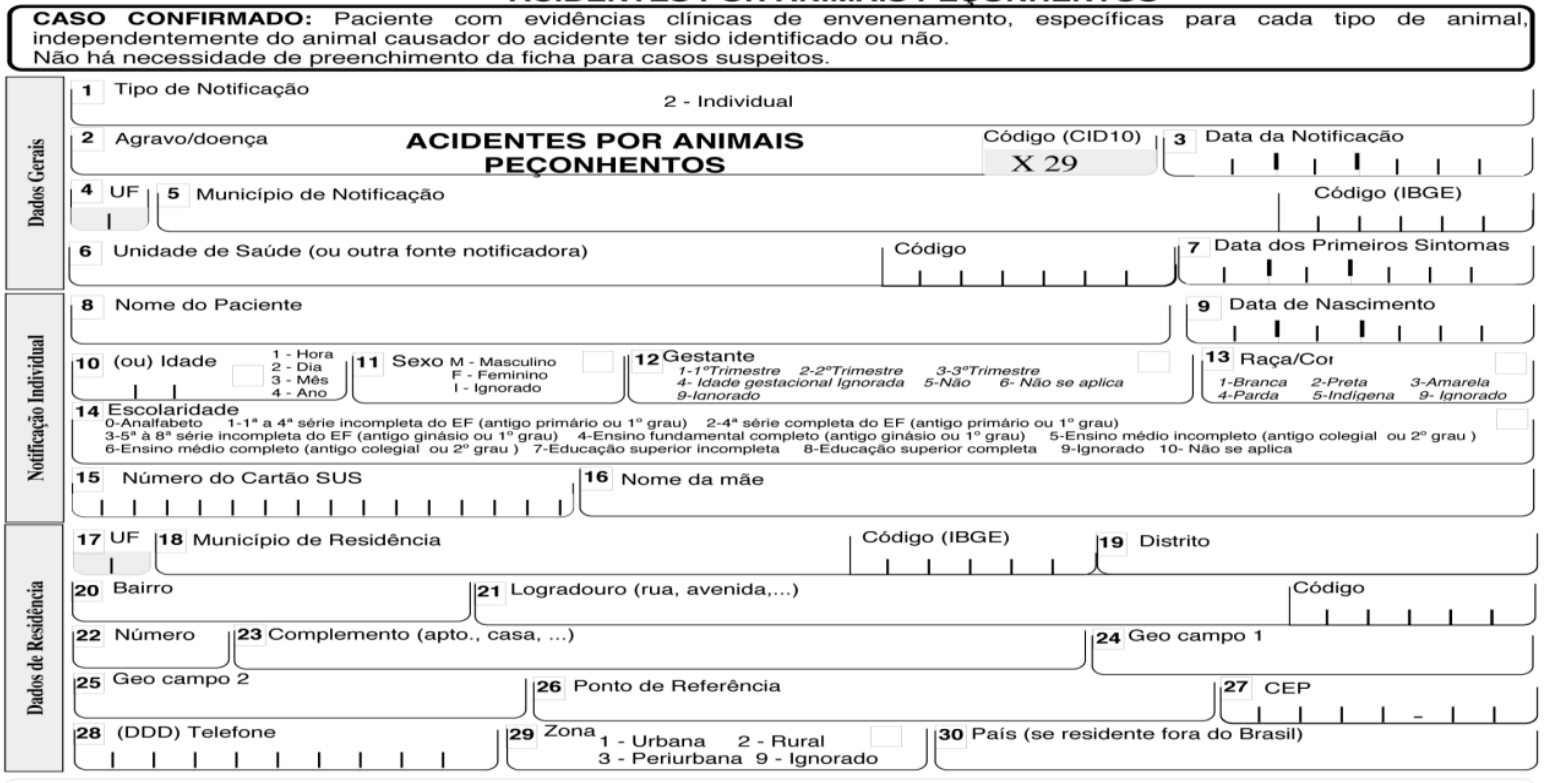

\section{Dados Complementares do Caso}

31 Data da Investigação 32 Ocupação

\begin{tabular}{lllllll}
1 & I & I & I & I & I & 1 \\
\hline 4 & UF & 35 & Município de & Ocorrênco
\end{tabular}

34 UF $35 \begin{gathered}\text { Município de Ocorrência } \\ \text { do Acidente: }\end{gathered}$

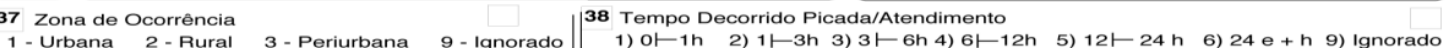

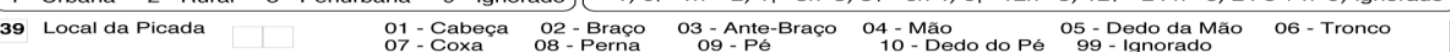

40 Manifestaçōes Locais $\quad|| 41$ Se Manifestações Locais Sim, especificar: 1 - Sim 2 - Não 9 - Ignorado

1 - Sim 2- Năo 9-Ignorado 4 Dor $\quad$ Edema $\square$ Equimose $\square$ Necrose $\square$ Outras (Espec.)

43 Se Manifestações Sistêmicas Sim, especificar: 1 - Sim 2 - Não 9 - Igno

Manifestações
Sistêmicas

1 - Sim

2 - Não
9 - Ignorac

neuroparalíticas (ptose
palpebral, turvação visual)

hemorrágicas (gengivorragi

miolíticas/hemoliticas (mialgia,

(renas (oliguratanta)

Ignorado

vagais (vômitos
diarréias)

Outras (Espec.)

44 Tempo de

1 - Normal

2 - Alterado
9 - Não
reâdo

5 Tipo de Acidente anemia, urina escura)

$\begin{array}{llll}\text { 1 - Serpente } & 2 \text { - Aranha } 3 \text { - Escorpião } & 4 \text { - Lagarta } \\ 5 \text { - Abelha } & 6 \text { - Outros } & & \text {-Ignorado }\end{array}$

47 Aranha-Tipo de Acidente

- Foneutrismo 2 - Loxoscelismo 3 - Latrodectismo

4-Outra Aranha 9-Ignorado

46 Serpente - Tipo de Acidente

1 - Botrópico 2 -Crotálico 3 - Elapídico 4 -Laquético

$\begin{array}{ll}1 \text { - Botrópico } 2 \text { - Crotálico } & 3 \text { - Elapídico } \\ 5 \text {-Serpente Não Peçonhenta } & 9 \text { - Ignorado }\end{array}$

1 - Lonomia 2 - Outra lagarta

9 - Ignorado 


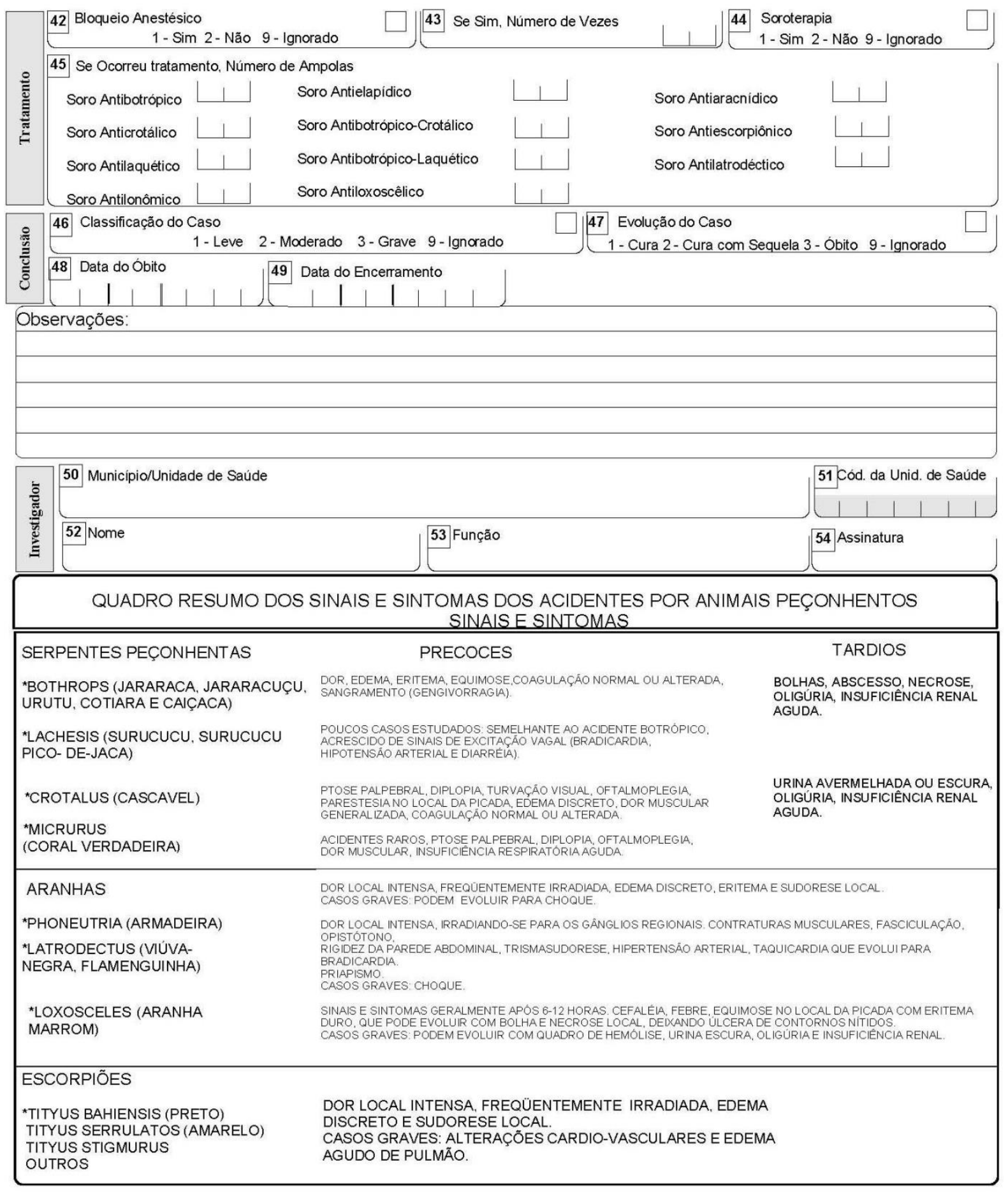


ANEXO II

Questionário socioeconômico da Associação Brasileira de Empresas de Pesquisa ABEP 2015

\begin{tabular}{|c|c|c|c|c|c|c|}
\hline \multirow{2}{*}{\multicolumn{2}{|c|}{ ITENS DE CONFORTO (EM QUANTIDADE) }} & \multirow{2}{*}{$\begin{array}{c}\text { NÃO } \\
\text { POSSUI } \\
0\end{array}$} & \multicolumn{4}{|c|}{$\begin{array}{l}\text { QUANTIDADE } \\
\text { QUE POSSUI }\end{array}$} \\
\hline & & & 1 & 2 & 3 & $4+$ \\
\hline \multicolumn{7}{|c|}{ Automóveis de passeio exclusivamente para uso particular } \\
\hline \multicolumn{7}{|c|}{$\begin{array}{l}\text { Empregadas mensalistas (trabalham pelo menos } 5 \text { dias por } \\
\text { semana) }\end{array}$} \\
\hline \multicolumn{7}{|c|}{ Máquinas de lavar roupa (exceto tanquinho) } \\
\hline \multicolumn{7}{|c|}{ Banheiros (com vaso sanitário) } \\
\hline \multicolumn{7}{|c|}{$\begin{array}{l}\text { DVD (incluindo qualquer dispositivo que leia DVD, exceto de } \\
\text { aparelho de automóvel) }\end{array}$} \\
\hline \multicolumn{7}{|c|}{ Geladeiras } \\
\hline \multicolumn{7}{|c|}{ Freezers independentes ou parte da geladeira duplex } \\
\hline \multicolumn{7}{|c|}{$\begin{array}{l}\text { Microcomputadores (computadores de mesa, laptops, notebooks } \\
\text { e netbooks, exceto tablets, palms ou smartphones) }\end{array}$} \\
\hline \multicolumn{7}{|c|}{ Lavadora de louças } \\
\hline \multicolumn{7}{|c|}{ Forno de micro-ondas } \\
\hline \multicolumn{7}{|c|}{$\begin{array}{l}\text { Motocicletas (exceto as que são utilizadas exclusivamente para } \\
\text { uso profissional) }\end{array}$} \\
\hline \multicolumn{7}{|c|}{ Máquina secadora de roupa (inclui máquina que lava e seca) } \\
\hline \multicolumn{7}{|c|}{ A ÁGUA UTILIZADA NO DOMICÍLIO É PROVENIENTE DE: } \\
\hline 1 & \multicolumn{6}{|c|}{ Rede geral de distribuição } \\
\hline 2 & \multicolumn{6}{|l|}{ Poço ou nascente } \\
\hline 3 & \multicolumn{6}{|c|}{ 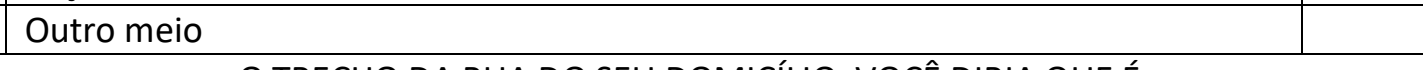 } \\
\hline \multicolumn{7}{|c|}{ O TRECHO DA RUA DO SEU DOMICÍLIO, VOCÊ DIRIA QUE É: } \\
\hline 1 & \multicolumn{6}{|c|}{ Asfaltada/pavimentada } \\
\hline 2 & \multicolumn{6}{|l|}{ Terra/cascalho } \\
\hline \multicolumn{7}{|c|}{$\begin{array}{l}\text { GRAU DE INTRUÇÃO DO CHEFE DA FAMÍLIA (PESSOA QUE CONTRIBUI COM MAIOR PARTE DA } \\
\text { RENDA DO DOMICÍLIO) }\end{array}$} \\
\hline 1 & \multicolumn{6}{|c|}{\begin{tabular}{|l|l} 
Anafabeto/Ensino fundamental I incompleto &
\end{tabular}} \\
\hline 2 & \multicolumn{6}{|l|}{ Ensino fundamental I completo/ Ensino fundamental II incompleto } \\
\hline 3 & \multicolumn{6}{|l|}{ Ensino fundamental completo/Ensino médio incompleto } \\
\hline 4 & \multicolumn{4}{|l|}{ Ensino médio completo/ Ensino superior incompleto } & & \\
\hline 5 & \multicolumn{4}{|l|}{ Ensino superior completo } & & \\
\hline
\end{tabular}


FICHA DE CONSULTA PARA SISTEMA DE PONTOS DA ABEP

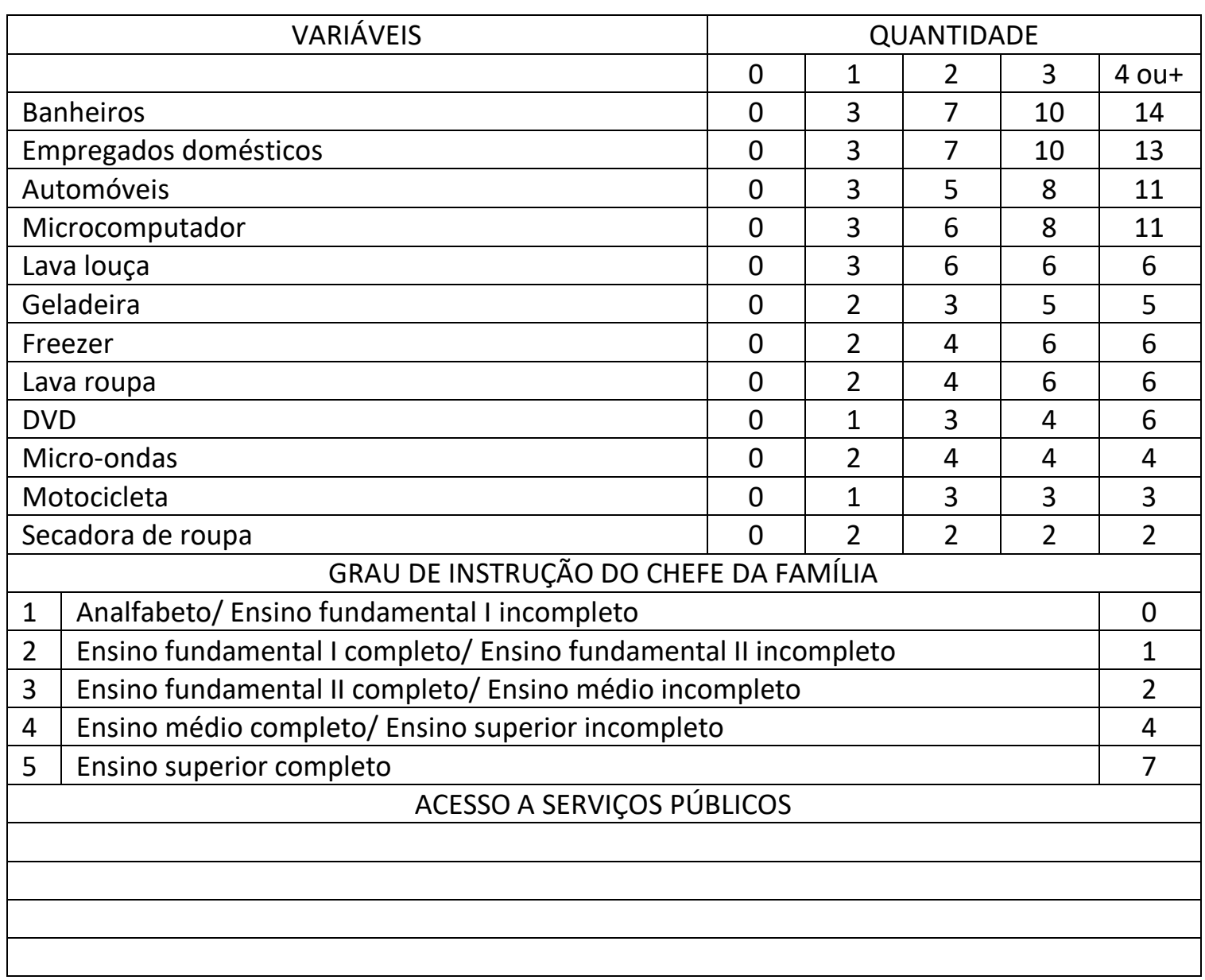




\section{UNIVERSIDADE DO ESTADO DO PARÁ - CAMPUS XII - TAPAJÓS UEPA}

\section{PARECER CONSUBSTANCIADO DO CEP}

\section{DADOS DO PROJETO DE PESQUISA}

Titulo da Pesqulsa: Caracterizaçăo clinica e epidemiológica dos acidentes escorpiónicos em Ruröpolis. Pará

Pesqulsador: Fernanda Jacqueline Teixeira Cardoso

Area Tematica:

Versao: 1

CAAE: 59234916.50000 .5168

Instituiçào Proponente: Centro de Ciencias Biokgicas e da Saúde - Campus XIIIUEPA

Patrocinador Principal: Finandiamento Próprio

\section{DADOS DO PARECER}

Numero do Parecer: 1.737 .875

\section{Apresentaçao do Projeto:}

$O$ acidente escorpiónioo é um evento que ocorre tanto em ambientes urbanos quanto rurais, onde o ser humano entra em oontato com os escorpiöes e estes se defendem, por sentirem-5e ameaçados. Ao entrarem em contato com o veneno do escorpiao, os individuos vao reagir de diversas formas, de acordo com seu organismo, que podem variar de ume simples dor local ou ate mesmo evoluir a obiso (BRASIL. 2009).

Trata-se de um grave problema de saude pública em todo o mundo e possui uma maior severidade quando ocorre em crianças. A grawidade do acidente escorpiçnico

varia conforme a quantidade de veneno injetada, toxicidade, espécie e tamanho do escorpiảo, local da picada, idade e sensibilidade da pessoa ao

veneno, além de fatores relacionados ao tratamento, como diagnóstico preccoe e o sempo decorrido desde 0 acidente ate a scroterapia (TORREZ et al. 2015).

Metodologia:Trata-se de um estudo observacional, descritivo e prospectivo A pesquisa será realizada nas dependencias do Hospital

Municips de Rurópolis, na cidade de Ruróoclis. Serão usilizsdos as dadcs dos prontuarios, principalmente de uma ficha protocolar insthuida $e$

utilizadsa no Hospital Municipal de Rurápolis, cnde serã̃a observados ce dados clinicos e

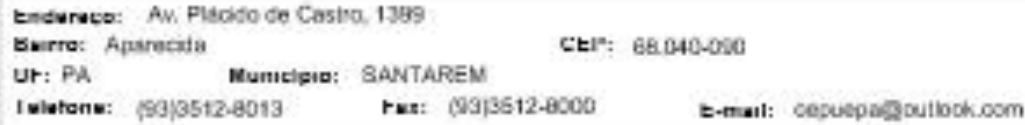




\section{UNIVERSIDADE DO ESTADO DO PARÁ - CAMPUS XII - TAPAJÓS UEPA}

Cancuinso do Pywer 1.737875

laboratoriais dos pscientes vitimas de escorpionismo.Serso

realizadas tambem entrevistas registradas em áudio com duraçăo de cerca de minutos na sala de enfermagem antes da alta hospitalar para

investigaçằ sobre os dados sociodemograficos, sobre as sensaçōes durante as manifestaçc̄es clinicas, bern como a intensidade, surgimento,

localizaçầ e cessaçâo das mesmas, com um roteiro de entrevista.

Objettvo da Peaqulea:

Objetivo: Estudar os aspectos epidemiológicos e clinicos dos acidentes escorpiónicos ocorridos no municipio de Rurópolis, oeste

paraense.

Avallaçao dos Rlıcos $\theta$ Beneficlos:

O possivel risco verificado é vazamento das informaçóes contidas no instrumentos de coleta da pesquisa pcrém este estudo primará pela confidência dos dados. Os beneficios desta pescuisa consistem em melhor compreensalo dos aspectos clínicos e epidemiologicos do escorpionismo no Municipio de Ruropolis no periodo de outubro de 2016 a março de 2017. Alem disso, a pesquisa também ira colaborar para a disseminsça de informaç̋̄es scerca desss tematica, estimular novos estudos por outros pesquisadores para essa ternática, e uma possivel medida que contribua para a redicgão de casos.

\section{Comentarios $\theta$ Conalderaçoes sobre a Pesqulas:}

De acordo com a metosologia proposta, considero invável a realizaç̧̄o đa pesquisa, uma vez que está prevista a coleta de dados por meio de entrevista direta com os pacientes no período de outubro de 2016 a março de 2017. considerando que as pescuisadoras nŭo residem em Rurcpolis.

Conalderaçбes aobre 08 Termos de apresentaçao obrigatorla:

Apresentou todos

Recomendaçoes:

Recomendo adequaçăo na metodologia proposta, ums vez que o projeto prevề entrevista direta com os pacientes no periodo de outubro de 2016 a março de 2017, considerando que as pesquisadoras não residem em Rurópolis, toenando inviável a realizaçāo deste trabalho.

Conclus 6 es ou Pendênclas $\theta$ Llata de Inadequaçסes:

SEM PENDENCIAS ETICAS

Conalderaçoes Finals a criterlo do CEP:

Os pesquisadores deverăo anexar os relatorios parcial e fins do estudo na Plataforma Brasil

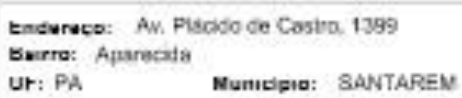




\section{UNIVERSIDADE DO ESTADO \\ DO PARÁ - CAMPUS XII - TAPAJÓS UEPA}

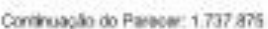

Eate parecer fol elaborado baseado nos documentos ababxo relaclonados:

\begin{tabular}{|c|c|c|c|c|}
\hline Tipo Documento & Arquivo & Postagem & Autor & Siltusçāo \\
\hline $\begin{array}{l}\text { Intormacbes Basicas } \\
\text { do Proieno }\end{array}$ & $\begin{array}{l}\text { PB_INFCAMMACOES_BASICAS_DO_P } \\
\text { RO_IETO 713922.pd! }\end{array}$ & $\begin{array}{c}260082016 \\
11: 11: 59\end{array}$ & & Aceno \\
\hline $\begin{array}{l}\text { TCLE / Termos de } \\
\text { Assentimento / } \\
\text { Justificentiva de } \\
\text { Auseancia }\end{array}$ & TCLES.pdf & $\begin{array}{c}2608 / 2016 \\
11: 03: 07\end{array}$ & $\begin{array}{l}\text { Fernanda Jacqueline } \\
\text { Teixcira Cardoso }\end{array}$ & Aceilo \\
\hline $\begin{array}{l}\text { Projeto Detalhado ? } \\
\text { Brochura } \\
\text { Invostigador }\end{array}$ & PROJETO_DETALHADO pdI & $\begin{array}{c}2608 / 2016 \\
11: 00: 57\end{array}$ & $\begin{array}{l}\text { Fernanda Jacqueline } \\
\text { Teixeira Cardoso }\end{array}$ & Aceino \\
\hline Outros & aceite_hospital.pdf & $\begin{array}{c}22 / 08 / 2016 \\
15: 57 ; 52\end{array}$ & $\begin{array}{l}\text { Fernanda Jacqueline } \\
\text { Teixcira Cardoso }\end{array}$ & Aceilo \\
\hline Outros & carta_aceite.pdf & $\begin{array}{c}22,08 / 2016 \\
15: 56: 07\end{array}$ & $\begin{array}{l}\text { Fernanda Jaccoucline } \\
\text { Teixeira Cardoso }\end{array}$ & Accino \\
\hline Folha de Rosto & Folha_rosto.pdf & $\begin{array}{c}2201512016 \\
10: 44: 14\end{array}$ & $\begin{array}{l}\text { Fernanda Jaccoucine } \\
\text { Teixeira Cardoso }\end{array}$ & Acento \\
\hline
\end{tabular}

situaçao do Parecer:

Aprovedo

Necessita Apreclaça da CONEP

Năo

SANTAREM, 21 de Sesembro de 2016

Assinado por:

Marla Goreth Sllva Ferrelrs

(Coordenador)

MUmbgid: SANTTAREM

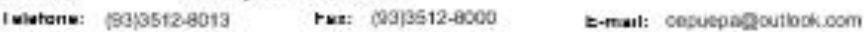


